Cochrane Database of Systematic Reviews

\title{
Single agent versus combination chemotherapy for metastatic breast cancer (Review)
}

Carrick S, Parker S, Thornton C, Ghersi D, Simes J, Wilcken N

Carrick S, Parker S, Thornton C, Ghersi D, Simes J, Wilcken N.

Single agent versus combination chemotherapy for metastatic breast cancer.

Cochrane Database of Systematic Reviews 2009, Issue 2. Art. No.: CD003372.

DOI: 10.1002/14651858.CD003372.pub3.

www.cochranelibrary.com 
TABLE OF CONTENTS

ABSTRACT

PLAIN LANGUAGE SUMMARY

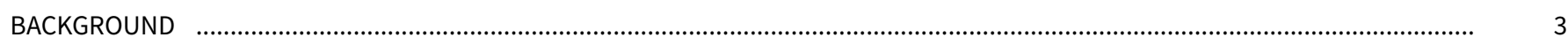

OBJECTIVES

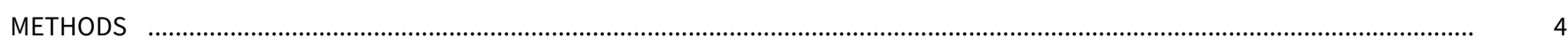

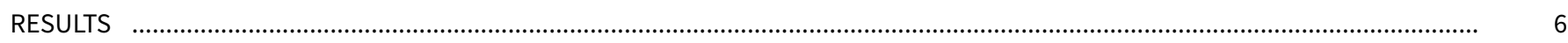

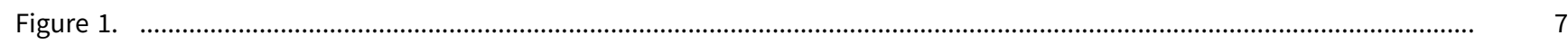

Figure 2.

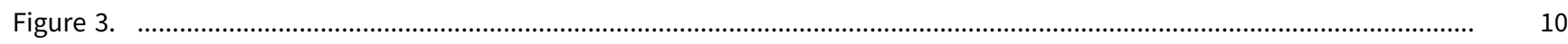

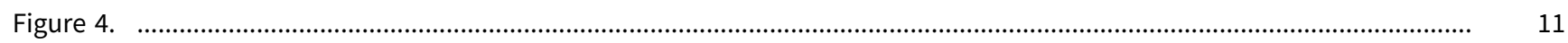

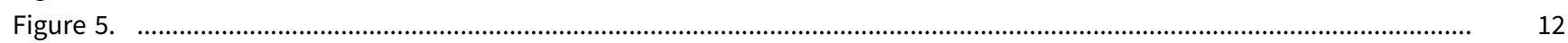

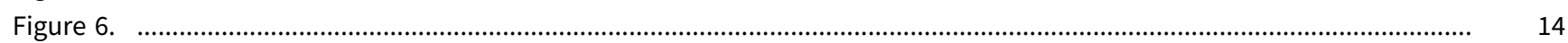

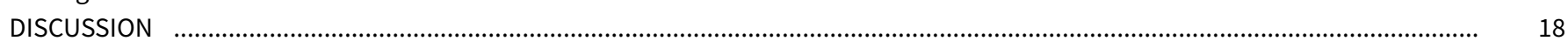

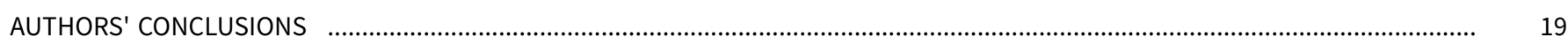

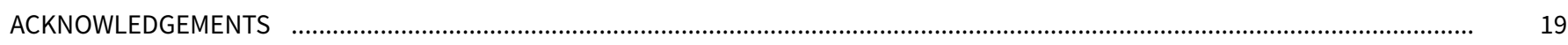

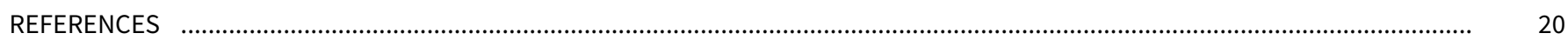

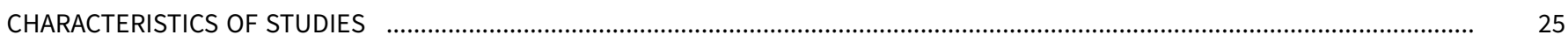

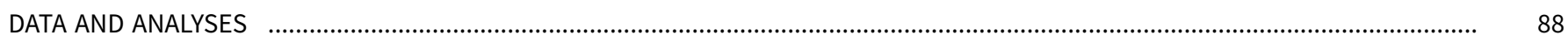

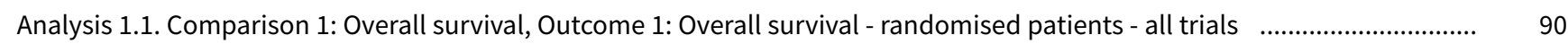

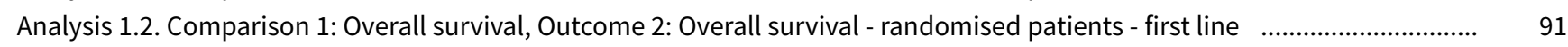

Analysis 1.3. Comparison 1: Overall survival, Outcome 3: Overall survival - Question 1 - Regimen A versus A + other - randomised 92

patients

Analysis 1.4. Comparison 1: Overall survival, Outcome 4: Overall survival - Question 2 - Regimen A versus Regimen C randomised patients

Analysis 1.5. Comparison 1: Overall survival, Outcome 5: Overall survival - single agent taxane versus all combination ........... Analysis 1.6. Comparison 1: Overall survival, Outcome 6: Overall survival - single agent anthracycline versus all combinations . Analysis 2.1. Comparison 2: Time to progression, Outcome 1: Time to progression - randomised patients - all trials ................ Analysis 2.2. Comparison 2: Time to progression, Outcome 2: Time to progression - randomised patients - first line ................ Analysis 2.3. Comparison 2: Time to progression, Outcome 3: Time to progression - Question 1 - Regimen A versus A + other randomised patients

Analysis 2.4. Comparison 2: Time to progression, Outcome 4: Time to progression - Question 2 - Regimen A versus Regimen C - randomised patients

Analysis 2.5. Comparison 2: Time to progression, Outcome 5: Time to progression - single agent taxane versus all combinations

Analysis 2.6. Comparison 2: Time to progression, Outcome 6: Time to progression - Single agent anthracycline versus all combinations

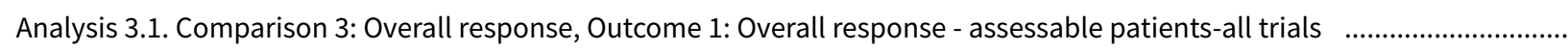

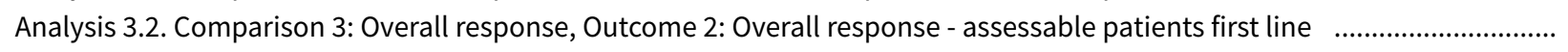
Analysis 3.3. Comparison 3: Overall response, Outcome 3: Overall response - Question 1- Regimen A versus A + other - assessable patients

Analysis 3.4. Comparison 3: Overall response, Outcome 4: Overall response - Question 2 - Regimen A versus Regimen C assessable patients

Analysis 3.5. Comparison 3: Overall response, Outcome 5: Overall response - single agent taxane versus all combinations ..... Analysis 3.6. Comparison 3: Overall response, Outcome 6: Overall response - single agent anthracycline versus all combinations

Analysis 4.1. Comparison 4: Toxicity - Nausea and vomiting, Outcome 1: Nausea and vomiting - asssessable patients - all trials . Analysis 4.2. Comparison 4: Toxicity - Nausea and vomiting, Outcome 2: Nausea and vomiting - Question 1 - Regimen A versus A + other - assessable patients

Analysis 4.3. Comparison 4: Toxicity - Nausea and vomiting, Outcome 3: Nausea and vomiting - Question 2 - Regimen A versus Regimen C - assessable patients

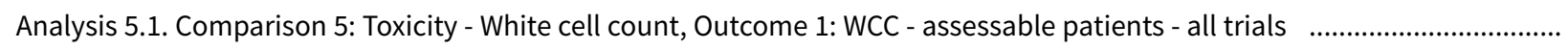
Analysis 5.2. Comparison 5: Toxicity - White cell count, Outcome 2: WCC - Question 1 - Regimen A versus A + other - assessable patients 
Analysis 5.3. Comparison 5: Toxicity - White cell count, Outcome 3: WCC - Question 2 - Regimen A versus Regimen C - assessable patients

Analysis 6.1. Comparison 6: Toxicity - Alopecia, Outcome 1: Alopecia - assessable patients - all trials

Analysis 6.2. Comparison 6: Toxicity - Alopecia, Outcome 2: Alopecia - Question 1 - Regimen A versus A + other - assessable patients

Analysis 6.3. Comparison 6: Toxicity - Alopecia, Outcome 3: Alopecia - Question 2 - Regimen A versus Regimen C -assessable patients

Analysis 7.1. Comparison 7: Treatment related death, Outcome 1: Treatment related death - assessable patients - all trials ....

WHAT'S NEW

HISTORY

CONTRIBUTIONS OF AUTHORS

DECLARATIONS OF INTEREST

SOURCES OF SUPPORT 
[Intervention Review]

\section{Single agent versus combination chemotherapy for metastatic breast cancer}

Sue Carrick ${ }^{1}$, Sharon Parker ${ }^{2}$, Charlene Thornton ${ }^{3}$, Davina Ghersi ${ }^{4}$, John Simes ${ }^{5}$, Nicholas Wilcken 6

1 Twins Research Australia, Melbourne School of Population and Global Health, The University of Melbourne, Melbourne, Australia. ${ }^{2}$ Centre for Primary Health Care and Equity, University of NSW, Sydney, Australia. ${ }^{3}$ School of Medicine, University of Western Sydney, Penrith, Australia. ${ }^{4}$ Research Policy and Translation, National Health and Medical Research Council, Canberra, Australia. ${ }^{5} \mathrm{NHMRC}$ Clinical Trials Centre, The University of Sydney, Camperdown, Australia. ${ }^{6}$ Medical Oncology, Crown Princess Mary Cancer Centre, Westmead, Australia

Contact: Sue Carrick, suecarrick@sevenswifts.com.

Editorial group: Cochrane Breast Cancer Group.

Publication status and date: Stable (no update expected for reasons given in 'What's new'), published in Issue 5, 2021.

Citation: Carrick S, Parker S, Thornton C, Ghersi D, Simes J, Wilcken N. Single agent versus combination chemotherapy for metastatic breast cancer. Cochrane Database of Systematic Reviews 2009, Issue 2. Art. No.: CD003372. DOI: 10.1002/14651858.CD003372.pub3.

Copyright () 2009 The Cochrane Collaboration. Published by John Wiley \& Sons, Ltd.

\section{A B S T R A C T}

\section{Background}

Combination chemotherapy regimens are frequently favoured over single agents for the treatment of metastatic breast cancer, in an attempt to achieve superior tumour response rates. It is not known however whether giving more intensive chemotherapy regimens results in better health outcomes, when both survival and toxicity are considered, and whether better response rates and rates of progression free survival actually translate to better overall survival.

\section{Objectives}

To compare single agent with combination chemotherapy for the treatment of metastatic breast cancer.

\section{Search methods}

We searched the Cochrane Breast Cancer Group Specialised Register November 2008. Handsearching of recent conference proceedings was also undertaken.

\section{Selection criteria}

Randomised trials of single agent chemotherapy compared to combination therapy in metastatic breast cancer.

\section{Data collection and analysis}

Two authors independently assessed trials for eligibility and quality, and extracted data. Hazard ratios were derived for reported time-toevent outcomes. Response rates were analysed as dichotomous variables. Toxicity and quality of life data were extracted where present.

\section{Main results}

Forty three eligible trials (48 comparisons) were identified. These included 9742 women, 55\% of whom were receiving first-line treatment for metastatic disease. For overall survival there was a statistically significant difference in favour of the combination regimens with no heterogeneity ( $\mathrm{HR} 0.88,95 \% \mathrm{Cl} 0.83-0.93, \mathrm{p}<0.00001)$. Results were very similar when trials of first-line treatment were analysed, and for analyses where the single agent was also included in the combination regimen. Combination regimens showed a statistically significant advantage for survival over single agent taxane ( $\mathrm{HR} 0.82 ; 95 \% \mathrm{Cl} 0.75-0.89, \mathrm{p}<0.00001)$, but not anthracycline $(\mathrm{HR} 0.94 .86-1.02, \mathrm{p}=0.15)$. 
Combination regimens were also associated with significantly better time to progression ( $\mathrm{HR} 0.78,95 \% \mathrm{Cl} 0.74-0.82, \mathrm{p}<0.00001)$ and response (RR $1.29,95 \% \mathrm{Cl} 1.14-1.45, \mathrm{p}<0.0001$ ) although heterogeneity was statistically significant in both instances and probably due to clinical diversity of the participants and interventions.

Women receiving combination regimens experienced a statistically significant detrimental effect on white cell count, increased alopecia and nausea and vomiting.

\section{Authors' conclusions}

Combination chemotherapy regimens show a statistically significant advantage for survival, tumor response and time to progression in women with metastatic breast cancer but they also produce more toxicity. An unresolved question is whether combination regimens are more effective than single agents given sequentially.

\section{PLAIN LANGUAGE SUMMARY}

\section{Single agent versus combination chemotherapy for metastatic breast cancer}

Metastatic breast cancer is cancer that has advanced and spread beyond the breast and regional lymph nodes. Although many women will live with advanced disease for many years, treatment is aimed at the alleviation of symptoms rather than cure. The first choice of treatment for advanced disease is dependent on hormone status (whether the tumour is stimulated to grow by oestrogen and progesterone) or whether the tumour overexpresses human epidermal growth factor receptor-2 (HER-2) and can be treated with trastuzumab (herceptin). Most women with advanced disease will however receive chemotherapy (anti-cancer agents) either as their first treatment, because their disease has become resistant to some treatments, or in combination with other types of treatments. Chemotherapy drugs can be given alone (single agent) or two or more drugs can be given together (combination chemotherapy). The aim of this review was to compare whether using a more intensive regimen (more than one drug) was better than the single agent treatment for women with advanced disease. We identified 43 eligible trials (48 comparisons- as some trials tested more than one comparison). These trials included 9742 women, 55\% of whom were receiving their first treatment with chemotherapy for metastatic disease. The review found a benefit for the combination chemotherapy for survival (all trials). This was also the case when trials of first-line treatment only were analysed, and whether the single agent was also included in the combination or not. Combination treatments were also associated with significantly better time to progression (time after treatment until the disease progressed) and response (whether the tumour gets smaller as a result of the treatment). Women receiving combination treatment however experienced more adverse effects of treatment including a decrease in their white cell count, increased hair loss and nausea and vomiting. For women making a decision about treatment, it should be noted that this review was not able to address the issue of whether combination regimens are more effective than sequential treatment with different single agents. Some individual trials raised the possibility that giving a multiagent regimen sequentially with immediate cross-over from one agent to the next on progression may result in survival times similar to that seen when all the agents are given together

An important consideration for women with advanced disease is the balance between the benefit of treatment and the harms or adverse effects that these treatments may have. Unfortunately only 11 trials in this review reported information relating to quality of life. In general, survival gains with combination therapy came at the cost of a significant increase in toxicity and impact on other psychological and social factors which are known to contribute to a sense of quality of life for this group of women. There were insufficient data in this review to comment on the overall impact of the two treatment options on net clinical benefit from the women's perspective. Women with advanced disease will therefore need to seek the information to allow them to make decisions about the potential benefits of additional treatments (small survival gains) in progressing metastatic disease and the impact this can have on their quality of life. 


\section{B A C K G R O U N D}

\section{Description of the condition}

Breast cancer is the most common type of cancer in women and the most common cause of cancer-death in that group. In 2000 there were over 1 million new cases and approximately 373,000 deaths from breast cancer world wide; with an age standardised death rate (ASR) of 12.51 (per 100,000 ). ASRs of 25 or greater were recorded that same year byfor Barbados (25.53), Belgium (26.63), Denmark (29.16), Hungary (25.21), Iceland (36.78), Ireland (25.76), Israel (26.32), Malta (28.39), the Netherlands (27.76), New Zealand (25.94), Switzerland (25.17), Uruguay (26.27) and the UK (26.81) (Ferlay 2002).

With advances over the last few decades, a greater proportion of women are being diagnosed with breast cancer at an earlier stage when curative approaches are still possible. Regardless, 20-85\% of patients depending on stage, tumour biology and treatments used will go on to develop distant metastases (disease which has spread to other parts of the body) Cardoso 2002. This may be due to subclinical micrometastases despite adequate primary therapy. An additional 6-10\% will present with metastatic disease at primary diagnosis (Colozza 2007). Metastatic disease is treatable but not curable. Average survival is currently between one to two years, although some women may live with the disease for many years with good quality of life (Colozza 2007 Smith 2006).

\section{Description of the intervention}

Treatment of metastatic breast cancer (MBC) with chemotherapy has undergone several distinct historical phases. Therapy with single agents was first introduced in the 1960's but these agents provided short tumour response. In the 1970's combination regimens such as $\mathrm{CMF}$ (cyclophosphamide, methotrexate and 5fluoricil) were developed demonstrating further improvements in response $(>40 \%)$ and time to progression. The incorporation of anthracyclines into newer generation regimens such as AC (doxorubicin and cyclophosphamide) came later in the 1980's (Nabholtz 2002). Taxanes (docetaxel, paclitaxel) emerged in the 1990 's as a result of a rapid collection of data from high quality prospective randomised controlled trials involving tens of thousands of patients. Taxanes were quickly recognised as evidence based components of therapy for metastatic breast cancer, initially tested as single agents in two settings, patients with, and without prior anthracycline exposure (Crown 2004).

In terms of predictive factors (patient or tumour characteristics that help to forecast a response to a given treatment), evidence exists in the metastatic setting only for an association between response to endocrine therapy and expression of hormone receptors, and response to trastuzumab related to human epidermal growth factor receptor-2 (HER-2) status (Colozza 2007, Nabholtz 2002). Trials that have attempted to identify prognostic factors for patients who may benefit from combination chemotherapy have been conducted but only oestrogen receptor status, disease free interval and number of visceral sites have been identified as having a positive relationship (Overmoyer 2003). In endocrine sensitive disease, treatment may safely begin with endocrine therapy (Wilcken 2003) but ultimately most women with metastatic breast cancer will receive chemotherapy either because they have hormone receptor negative disease or because their disease has become refractory to endocrine therapy (Hortobagyi 1996). Currently trastuzumab is recommended at the same time as chemotherapy for patients who have not already received chemotherapy for metastatic breast cancer or given alone to patients who have already received chemotherapy for metastatic disease or if chemotherapy is not appropriate (NBCC 2007). Anthracycline combinations are frequently used as first line treatment in hormone-unresponsive MBC and taxanes are extensively used in combination with anthracyclines or when treatment with anthracyclines has failed (Martín 2007)

Generally speaking, most chemotherapeutic agents used in the treatment of cancer show a steep dose-response curve in preclinical studies. This has led cancer clinicians and researchers to conclude that increasing the intensity of treatment will result in an increase in the rate and duration of response, and hence to improvements in survival (Hryniuk 1987). Increased dose intensity may also come at the cost of increased toxicity. If palliation is the primary goal of treatment, and anticipated survival is limited, then toxicity and quality of life become important factors when deciding on a treatment regimen.

\section{How the intervention might work}

It is commonly thought that combining chemotherapy agents will result in regimens that are more active with improved tumour response and progression rates and hence, better overall survival.

The question of whether to use single agent chemotherapy or combinations when treating women with metastatic breast cancer however remains partially unresolved. Experience over the last thirty years suggests that the use of polychemotherapy produces a higher response rate and increased time to progression (TTP) when compared to a single agent. A systematic review by Fossati (Fossati 1998) included survival analysis of polychemotherapy agents versus single agents in 2,442 patients. This review found a significantly better complete and partial response rate associated with the combination regimens and a survival advantage (HR 0.82 , $95 \% \mathrm{Cl}, 0.75$ to 0.90$)$.

More recently, two large individual trials have also demonstrated survival benefits for combination regimens when compared with very credible single agents, both in the post-anthracycline setting. In the first (O'Shaughnessy 2002), docetaxel plus capecitabine led to better overall survival than docetaxel alone with an improvement of 3 months in median survival and no measurable decline in quality of life. Toxicity was described as manageable, although anecdotal reports suggest this is a relatively toxic regimen and many clinicians do not use it. The second study has been presented but not yet published in the peer-reviewed literature (Albain KS 2004). Women received either paclitaxel alone (3 weekly) or with gemcitabine, and again overall survival was better, with an improvement in median survival of about 3 months. Toxicity is again described as manageable, and this is borne out by anecdotal reports.

In addition, single agent gemcitabine, capecitabine and vinorelbine have been shown to be effective for patients who have progressed during or following anthracycline treatment with response rates of $20-30 \%$, median survival of one year and acceptable safety profiles (O'Shaughnessy 2002, O'Shaughnessy 2005). 


\section{Why it is important to do this review}

Opinion is currently divided as to whether improvements in response and time to progression (TTP) necessarily correlate with an improvement in survival in this setting, or, whether combination chemotherapy is superior to the sequential use of single agent anthracyclines and taxanes (Cardoso 2002, Nabholtz 2002, O'Shaughnessy 2005).It is also not known which patients will benefit from which regimens. Combination regimens such as anthracycline/ taxane combinations are considered appropriate by some clinicians for patients with rapidly progressing visceral disease (i.e. hepatic metastases, pulmonary lymphangitic spread) followed by sequential single agent treatment (Overmoyer 2003, Seidman 2003) and others find this approach more appropriate in an adjuvant setting (Seidman 2003).

\section{O B J E C T IVES}

The objective of this review was to compare single-agent chemotherapy with combination chemotherapy regimens in the management of women with metastatic breast cancer. This includes the following:

- Question 1: regimen A (drug A alone) versus drug A plus other (for example methotrexate versus cyclophosphamide, methotrexate and 5-fluorouracil)

- Question 2: regimen A (drug A alone) versus drug C plus other (for example docetaxel versus 5-fluorouracil plus vinorelbine)

\section{METHODS}

\section{Criteria for considering studies for this review}

\section{Types of studies}

Randomised controlled clinical trials.

\section{Types of participants}

Included were women with advanced (metastatic) breast cancer, either newly diagnosed or recurrent. Trials including both women with metastatic disease and women with locoregionally recurrent disease were eligible for inclusion if data were provided separately for each group, or if women with isolated locoregional recurrence comprised less than $20 \%$ of the total group. There were no age restrictions.

In the protocol for this review it was proposed that trials containing women receiving first line chemotherapy (no previous chemotherapy for metastatic disease) only be included in this review. This was later changed to include subsequent lines of treatment. Hence, results are presented by treatment line (i.e. $100 \%$ first-line and all lines combined). Trials with participants with locoregional disease were not included in the analysis of $100 \%$ firstline therapy for metastatic disease.

\section{Types of interventions}

Intervention Group: any conventional chemotherapy regimen containing a combination of chemotherapeutic agents.

Comparator: any conventional single-agent chemotherapy regimen.

This includes the following:
- Question 1: regimen A (drug A alone) versus drug A plus other (for example methotrexate versus cyclophosphamide, methotrexate and 5-fluorouracil)

- Question 2: regimen A (drug A alone) versus drug C plus other (for example docetaxel versus 5 -fluorouracil plus vinorelbine)

Trials where endocrine therapy was given to both treatment groups were also included as were trials that may, or may not, have specified recommended treatment upon disease progression or initial treatment failure. High dose chemotherapy regimens were excluded.

Patients with advanced disease who progress on the treatment they are randomised to receive, will often have treatment changed at the time of progression. In some instances this may involve crossing over to the other arm of the trial and in other cases may involve receiving other treatment off-study. Trials where patients crossed over to the other treatment arm at the time of progression are, therefore, included in this review and analysed according to the treatment they were first randomised to receive. Sequential trials where patients were allocated to receive a set number of cycles of one treatment and then crossed over to the other treatment arm (not at the time of progression but upon completion of the first treatment) are included only where data are reported for the first treatment.

\section{Types of outcome measures}

1. Overall survival (OS) - time from date randomised to date of death (any cause).

2. Time to progression (TTP)- time from date randomised to date of progression or death (any cause). This is also referred to as Progression-free survival (PFS).

3. Response - the proportion of patients with a complete or partial response (Complete response is defined as complete disappearance of all measurable disease for some minimum time period. Partial response is defined as shrinkage of tumour such that shrinkage post-treatment is $<50 \%$ of shrinkage pre-treatment for some minimum time period in the absence of growth of any lesion or the appearance of new lesions).

4. Quality-of-life measures (trial specific instruments)

5. Toxicity (Grade 3 or more: WHO criteria) - Toxicities of interest were nausea and vomiting, alopecia, and reduction in the level of white cell count $($ WCC $<2000)$ (Leukopenia, neutropenia)

Time to treatment failure (TTF) was a planned outcome for this review. It was defined as time from date randomised to date of progression, death (any cause), withdrawal due to adverse event, patient refusal or further anti-cancer therapy for documented progression. Five trials (seven comparisons) reported TTF (ANZBCTG 2001; Falkson G 1990; French Epi (A) 1991; French Epi (B) 1991; Nabholtz JM 1999;Sledge G(A) 2003; Sledge G(B) 2003) however not all trials used definitions in alignment with our prespecified definition. This outcome was therefore not included in this review. However one trial (Sledge G(A) 2003; Sledge G(B) 2003) labelled a curve as TTF but reported the outcome as TTP. In the absence of a clear definition by the trial report, and taking into account their reporting of the data as TTP, this trial was included in the analysis for TTP.

This review also attempted to investigate treatment-related death, which for the purpose of this review is defined as death due to the toxicity of the drug and not to disease progression. If an individual 
trial did not include the definition used by that trial but used the terms "toxic death" or "lethal toxicity", or indicated that death was due to treatment, then the information was included in the review.

\section{Search methods for identification of studies}

\section{Electronic searches}

\section{(a) Cochrane Breast Cancer Specialised Register}

For the first full version of this review (Carrick 2005), the Specialised Register maintained by the Cochrane Breast Cancer Group was searched on 13/08/2004 (details of search strategies used by the group for the identification of studies and the procedure used to code references are outlined in the group's module http://www.mrw.interscience.wiley.com/ cochrane/clabout/articles/BREASTCA/frame.html ). Studies coded as 'advanced breast cancer' and 'chemotherapy' on the Specialised Register were extracted for consideration. This search was repeated on $12 / 11 / 2008$ for this update.

\section{Searching other resources}

\section{Conference Proceedings}

Abstracts and posters from conferences were also included if they provided sufficient information on the results to warrant their inclusion for this review update.

The American Society of Clinical Oncology (ASCO) conference proceedings 2004 and 2007 were searched for any relevant abstracts. Only ASCO conference proceedings from 2004 and 2007 were searched as all other years are already included in the Cochrane Breast Cancer Specialised Register.

\section{References from Published Studies}

The reference lists of other related literature reviews, such as those by Fossati 1998 and Stockler 2000 were searched for the original review only.

A copy of the full article for each reference reporting a potentially eligible trial was obtained, where possible. Where this was not possible, attempts were made to contact authors to provide additional information.

Reference lists were not searched for the updated review as they had already been searched for the original review.

\section{Unpublished Literature}

Unpublished data were included if there were results available.

\section{Data collection and analysis}

\section{Selection of studies}

At least two authors (SC, SP or CT) applied the selection criteria (including the quality of randomisation) to each reference identified by the search strategy. A third reviewer resolved any discrepancies regarding eligibility or quality.

\section{Data extraction and management}

The primary outcomes were overall survival (OS) and time-toprogression (TTP)/progression-free survival (PFS) for which the hazard ratio (HR) is the most appropriate statistic. When possible, the $\mathrm{HR}$ and associated variances were extracted directly from the trial publication(s). If not reported the HR was obtained indirectly using the methods described by Parmar 1998 by using either other available summary statistics or by extracting data from published Kaplan-Meier curves. The hazard ratio (HR) and associated statistics were calculated, where necessary, using an Excel spreadsheet developed by the Meta-analysis Group of the MRC Clinical Trials Unit, London (Tierney 2007). To allow for immature follow up the numbers at risk were adjusted based on estimated minimum and maximum follow-up times. If these were not reported in any of the reports available, minimum follow up was estimated using the estimated time taken to complete a cycle of treatment, and maximum follow-up was estimated based on the last reported event on the curve. These follow-up estimates are recorded in the Characteristics of included studies table under Notes.

A pooled HR was obtained from the derived observed (O) minus expected (E) number of events and the variance for each trial, using the fixed-effect model (Yusuf 1985). The pooled HR represents the overall risk of an event on a combination regimen versus a regimen where only one chemotherapy agent was used. HRs less than 1.0 favour combination regimens and values greater than 1.0 favour the control group (single drug chemotherapy).

Response rates were analysed as dichotomous variables (complete and/or partial versus stable disease or no response) and a pooled relative risk was derived. Response has been reported based on assessable (not randomised) patients as most of the trials reported the data for this group. Random effects model was used for pooling as there was significant heterogeneity. Toxicity was analysed by extracting the total number of grade III and/or IV events and the number at risk for each trial. These were summed and used to calculate a single relative risk (with 95\% confidence intervals). The specific toxicities of interest for this review were effect of chemotherapy on WCC (leukopenia and neutropenia), nausea or vomiting and alopecia.

Quality-of-life data were collated from those trials reporting it. Trials used a variety of instruments (Table 1 ). As a result, data were not statistically synthesised but summarised and evaluated qualitatively.

This review also attempted to investigate treatment-related deaths which, for the purpose of this review, were defined as deaths due to the toxicity of the drug and not related to disease progression. If an individual trial did not define treatment related death but used the terms "toxic death" or "lethal toxicity" then the information was included in the review.

Where multi-arm trials were included in the meta-analysis and one treatment arm was included in more than one treatment comparison, the number of events and the number of women in that arm were divided by the number of treatment comparisons. This method was used to avoid the multiple use of women in the pooled estimate of treatment effect while retaining information from each arm of the trial.

\section{Assessment of risk of bias in included studies}

Risk of bias was assessed using the Cochrane domain based evaluation. 


\section{Assessment of heterogeneity}

Heterogeneity was assessed by visual inspection of the forest plots and the chi squared test and I squared statistic. A random-effects meta-analysis was used for pooling the outcomes of response and toxicity and a $P$ value of 0.10 was used to determine statistical significance for the chi-squared test for these outcomes.

\section{Subgroup analysis and investigation of heterogeneity}

Proposed sub-group analyses (by menopausal status, hormone receptor status and disease stage) were not conducted because the information was not reported or because the data were difficult to extract from the trial reports.

\section{Post hoc protocol amendment}

Post-hoc subgroup analyses were conducted for type of regimen. In addition studies incorporating non-standard chemotherapy (high dose chemotherapy) were excluded as these are the subject of a separate review.

\section{RES U LTS}

\section{Description of studies}

For the first review conducted in 2004, the Specialised Register of the Cochrane Breast Cancer Group contained 5,472 references of which 857 were coded as references to studies of chemotherapy and advanced breast cancer. For this search 198 were identified as potentially relevant to the review but 148 were excluded. Fifty complete papers were obtained leading to the exclusion of a further 13 references. This left a total of 37 references to trials for inclusion in the meta-analysis. Because some of the trials incorporated two comparators, 42 separate comparisons were included in the original review.

For this update, a further 15 references to trials were screened. This resulted in the inclusion of 6 new trials (Albain KS 2004, GEICAM 2007, Norris B 2000; O'Shaughnessy J 2001; Stockler M 2006, Thomas E 2008) and 2 trials which had previously been classified as 'ongoing' (Ejlertsen B 2004; Heidemann E 2004). In addition two RCTs included in the first review Keller AM 2004; Liu T 1986) were excluded on the basis of further assessment during the update. Ultimately 43 trials (yielding 48 comparisons) were included in the review update (Figure 1). 
Figure 1. Quorum flow chart

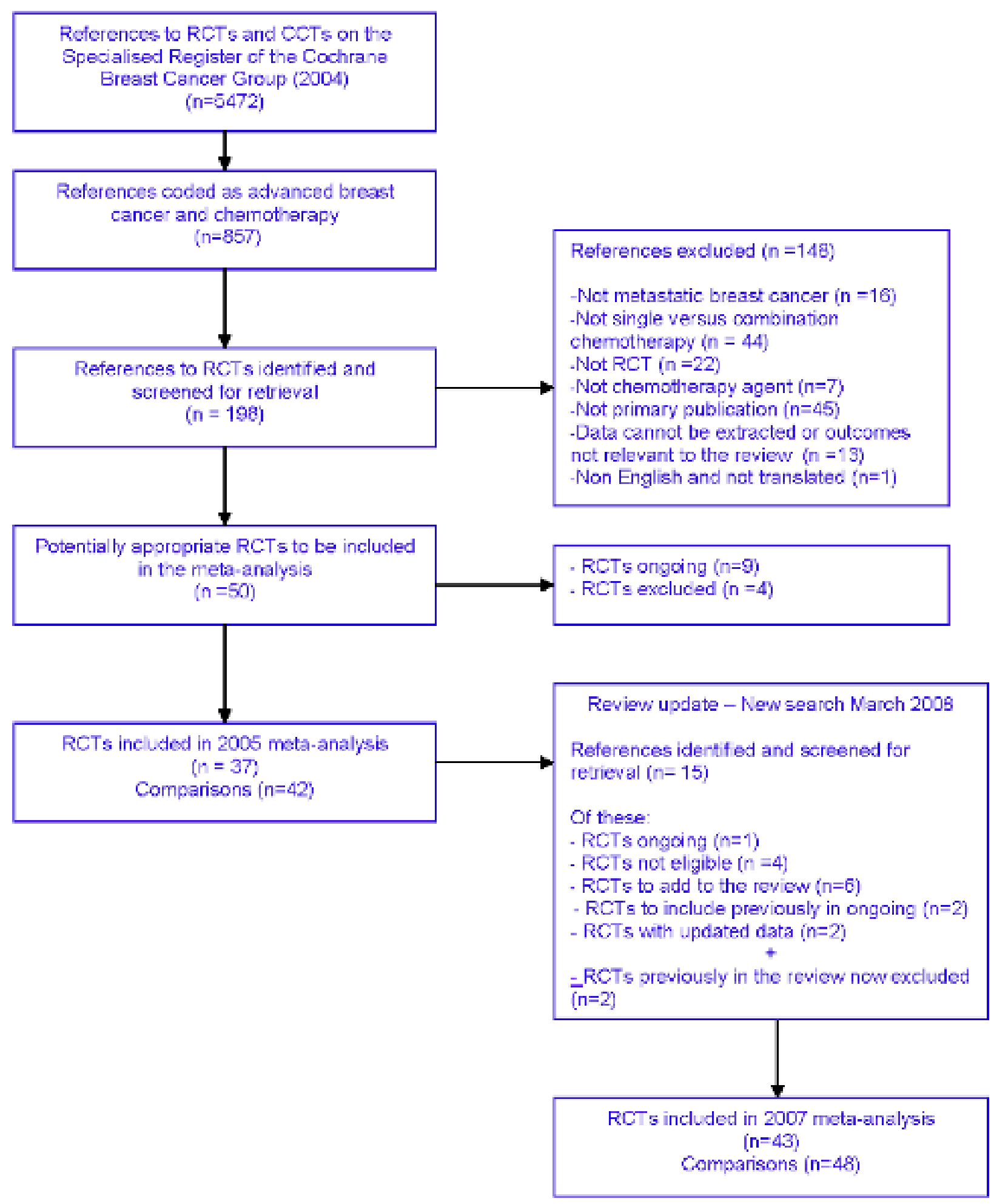

A summary of the trials included in the analyses and the questions that they address can be found in Additional Figures 02 and 03 . The five included trials that used two comparators are French Epi 1991; Hoogstraten 1976; Venturino 2000; Sledge 2003 and Takayama 2000. To accommodate the data-entry requirements of
Review Manager, the separate comparators for these trials have been referenced as $A$ and $B$ in this review.

Thirty trial comparisons addressing question A were included (Ahmann DL 1974(1); Ahmann DL 1974(2); Albain KS 2004; 
Andersson M 1986; Berruti D 2002; Carmo-Pereira 1980; Ejlertsen B 2004; Falkson G 1990; French Epi (A) 1991; French Epi (B) 1991; GEICAM 2007, Gundersen S 1986; Heidemann E 2004; Ingle J 1985; Ingle J 1989; Joensuu H 1998; Mouridsen HT 1977; Nielsen D 2000; Nielson D 1990; Norris B 2000; O'Shaughnessy J 2002; Rubens RD 1975; Sledge G(A) 2003; Sledge G(B) 2003; Steiner R 1983; Takayama T(A) 2000; Takayama T(B) 2000; Tashiro H 1994; Thomas E 2008, Vaughn CB 1988) .

Eighteen eligible trial comparisons addressing question $B$ were identified ( Ahmann DL 1974(3); ANZBCTG 2001; Bishop
J 1999; Bonneterre J 2002; Canellos GP 1976; Eagan RT 1976; Erkisi M 1997; Fraser S 1993; Heidemann E 2002; Hoogstraten B(A)1976; Hoogstraten B(B)1976; Icli F 2005, Nabholtz JM 1999; O'Shaughnessy J 2001; Sjostrom J 1999; Stockler M 2006; Venturino A(A) 2000; Venturino A (B) 2000).

Not all trials identified provided information on all outcomes. Please refer to Figure 2 and Figure 3 for a summary. 
Figure 2. Summary of included trials with extractable data Q1

\begin{tabular}{|c|c|c|c|c|c|c|c|c|}
\hline Trial ID & $\begin{array}{l}\text { Survival } \\
\text { Curve }\end{array}$ & $\begin{array}{l}\text { Median } \\
\text { survival }\end{array}$ & $\begin{array}{l}\text { TrP } \\
\text { Curve }\end{array}$ & $\begin{array}{l}\text { Median } \\
\text { TTP }\end{array}$ & $\begin{array}{l}\text { Overall } \\
\text { response }\end{array}$ & $\begin{array}{l}\text { Grade III/IV } \\
\text { Tosicity }\end{array}$ & $\begin{array}{l}\text { Treatment } \\
\text { relaled } \\
\text { deaths }\end{array}$ & $\begin{array}{l}\text { Sub- } \\
\text { group }\end{array}$ \\
\hline \multicolumn{9}{|c|}{ Q1. Regimen A versus A + olher } \\
\hline Ahmuxin $\mathrm{DL}_{1}$ 1974(1) & $\mathrm{Y}$ & $\bar{Y}$ & $\mathrm{NR}$ & $\overline{N R}$ & $\mathrm{Y}$ & $\sqrt{\mathrm{NE}}$ & Nil repcried & $\mathrm{B}$ \\
\hline $\begin{array}{l}\text { Ahmann } \mathrm{DL}_{4} \\
1974(2)\end{array}$ & $\mathrm{Y}$ & $\mathrm{Y}$ & $\overline{\mathrm{NR}}$ & $\overline{\mathrm{NR}}$ & $\mathrm{NR}$ & NE & Nil reponted & $\bar{B}$ \\
\hline $\begin{array}{l}\text { Albain K } \\
2004\end{array}$ & $\mathrm{Y}$ & $\mathrm{Y}$ & $\mathrm{Y}$ & $\mathrm{Y}$ & $\mathrm{Y}$ & $\begin{array}{l}\text { Nivomiting } \\
\text { Neutropenia }\end{array}$ & $\mathrm{N}-2$ & $\mathrm{D}$ \\
\hline $\begin{array}{l}\text { Andertson M } \\
1986\end{array}$ & $\mathrm{Y}$ & $\mathrm{NR}$ & $\mathrm{Y}$ & $\mathrm{Y}$ & $\bar{Y}$ & Nivomiting & $\mathrm{N}-4$ & A \\
\hline $\begin{array}{l}\text { Bemueti D } \\
2002\end{array}$ & $\mathrm{XN}$ & $\overline{\mathrm{NR}}$ & $\bar{Y}$ & $\mathrm{NR}$ & $\bar{Y}$ & $\begin{array}{l}\text { Nwowiting } \\
\text { Leukcyeniia }\end{array}$ & $\mathrm{N}=6$ & $\bar{A}$ \\
\hline $\begin{array}{l}\text { Commo-Periers I } \\
1980\end{array}$ & $Y$ & $\bar{Y}$ & $\overline{\mathrm{NR}}$ & NR & $\bar{Y}$ & $\begin{array}{l}\text { Nivomiting } \\
\text { Alkquecin } \\
\text { Laukopenia }\end{array}$ & Nil reporited & $\mathrm{c}$ \\
\hline $\begin{array}{l}\text { Fylertsen B } \\
2004\end{array}$ & $\mathrm{\gamma}$ & 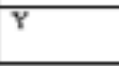 & $\mathrm{Y}$ & $\mathrm{N}$ & Y & $\begin{array}{l}\text { Nivomiting } \\
\text { Leulsopenia }\end{array}$ & $\mathrm{N}=11$ & A \\
\hline $\begin{array}{l}\text { Fallese G } \\
1990\end{array}$ & $\mathrm{Y}$ & $\bar{Y}$ & $\mathrm{NR}$ & $\bar{Y}$ & $\bar{Y}$ & NR & Nil reported & $\mathrm{B}$ \\
\hline $\begin{array}{l}\text { Freach Epi Group (A) } \\
1991\end{array}$ & $\mathrm{Y}$ & $\mathrm{NR}$ & $\mathrm{Y}$ & $\mathrm{NR}$ & $\bar{\gamma}$ & NE & Nil reporied & A \\
\hline $\begin{array}{l}\text { Frendil Epi Croup (B) } \\
|99|\end{array}$ & $\overline{\mathrm{Y}}$ & $\mathrm{NR}$ & $\mathrm{Y}$ & NR & $\mathrm{Y}$ & $\overline{\mathrm{NE}}$ & Nil reporied & $A$ \\
\hline GENCAM 2007 & $\overline{\mathrm{N}}$ & $\bar{Y}$ & $\mathrm{Y}$ & $\mathrm{Y}$ & $\mathrm{Y}$ & $\begin{array}{l}\text { NVormiting } \\
\text { Alkposis } \\
\text { Neutropenis }\end{array}$ & $\mathrm{N}=2$ & $\begin{array}{l}\text { Nu sub- } \\
\text { group }\end{array}$ \\
\hline $\begin{array}{l}\text { Ounderson S } \\
1986\end{array}$ & $\mathrm{Y}$ & $\mathrm{NR}$ & $\mathrm{NR}$ & NR & $\mathrm{Y}$ & $\begin{array}{l}\text { Nivomiting } \\
\text { Alkposis }\end{array}$ & Nil reported & $\mathrm{A}$ \\
\hline $\begin{array}{l}\text { Ilcidemann E } \\
2004\end{array}$ & $\mathrm{Y}$ & $\mathrm{Y}$ & $\mathrm{Y}$ & $\mathrm{Y}$ & $\mathbf{Y}$ & $\begin{array}{l}\text { N/Vomitiag } \\
\text { Leukcpenia }\end{array}$ & Nil repontod & $\mathrm{A}$ \\
\hline $\begin{array}{l}\text { Ingle J } \\
1985\end{array}$ & $\mathrm{Y}$ & $\bar{Y}$ & $Y$ & $Y$ & $\bar{Y}$ & $\begin{array}{l}\text { N/vowiting } \\
\text { Leukcopenia } \\
\text { alopecia }\end{array}$ & $\mathrm{N}-3$ & $A$ \\
\hline $\begin{array}{l}\text { Ingle J } \\
1989\end{array}$ & $\mathrm{Y}$ & $\mathrm{Y}$ & $\mathrm{Y}$ & $\mathrm{Y}$ & $\mathrm{Y}$ & $\begin{array}{l}\text { N.voniting } \\
\text { Laukopenia }\end{array}$ & $\mathrm{N}=3$ & A \\
\hline $\begin{array}{l}\text { Jaensum H } \\
1998\end{array}$ & $\mathrm{Y}$ & $\mathrm{Y}$ & $\mathrm{Y}$ & $\mathrm{Y}$ & $\mathrm{Y}$ & $\begin{array}{l}\text { Nivoniting } \\
\text { Aloposia } \\
\text { Leukapenia }\end{array}$ & Nil reporited & A \\
\hline $\begin{array}{l}\text { Mourisden II } \\
1977\end{array}$ & $\mathrm{NR}$ & $\mathrm{NR}$ & $\mathrm{NR}$ & $\mathrm{NR}$ & $\mathrm{Y}$ & $\begin{array}{l}\text { Alopocia } \\
\text { Lenkopenia }\end{array}$ & Nil reported & B \\
\hline $\begin{array}{l}\text { Niclsen D } \\
2000\end{array}$ & $\mathrm{Y}$ & $\mathrm{Y}$ & \begin{tabular}{|l|l}
$Y$ \\
\end{tabular} & $Y$ & $\bar{Y}$ & $\mathrm{NR}$ & $\mathrm{N}-6$ & $A$ \\
\hline $\begin{array}{l}\text { Nizlson D } \\
1990\end{array}$ & $\bar{Y}$ & $\bar{Y}$ & $\bar{Y}$ & $\bar{Y}$ & $\bar{Y}$ & NE & $\mathrm{N}=4$ & $A$ \\
\hline $\begin{array}{l}\text { Norris B } \\
2000\end{array}$ & $\bar{Y}$ & $\bar{Y}$ & $\mathrm{~N}$ & $\mathrm{Y}$ & $\bar{Y}$ & $\begin{array}{l}\text { N.vomiting } \\
\text { Alkpecis } \\
\text { Granulo-cytopsnia }\end{array}$ & $\mathrm{N}-3$ & $\mathrm{~A}$ \\
\hline $\begin{array}{l}\text { OShaughessy J } \\
2002\end{array}$ & $\mathrm{Y}$ & $\bar{Y}$ & $\bar{Y}$ & $\bar{Y}$ & $\mathrm{Y}$ & $\begin{array}{l}\text { N/vomiting } \\
\text { Alopecis } \\
\text { Neutrupenis }\end{array}$ & $\mathrm{N}=5$ & $\mathrm{D}$ \\
\hline $\begin{array}{l}\text { Rubens RD } \\
1975\end{array}$ & $\mathrm{Y}$ & $\mathrm{NR}$ & $\mathrm{NR}$ & NR & $\bar{Y}$ & NR & $\mathrm{N}-1$ & B \\
\hline $\begin{array}{l}\text { Sledge } G(A) \\
2003\end{array}$ & $\bar{Y}$ & $\bar{Y}$ & $\bar{Y}$ & $\bar{Y}$ & $\bar{Y}$ & $\begin{array}{l}\text { Nivonitiang } \\
\text { Leulopipeniz }\end{array}$ & $\mathrm{N}=\mathrm{8}$ & A \\
\hline $\begin{array}{l}\text { Sledge O (B) } \\
2003\end{array}$ & $\mathrm{Y}$ & $\bar{Y}$ & $\mathrm{Y}$ & $\bar{Y}$ & $\bar{Y}$ & $\begin{array}{l}\text { Leakopenia } \\
\text { Vomiting }\end{array}$ & $\mathrm{N}=6$ & $\mathrm{D}$ \\
\hline $\begin{array}{l}\text { Stinar R } \\
1983\end{array}$ & $\mathrm{SR}$ & $\overline{\mathrm{Y}}$ & $\mathrm{NR}$ & NR & $\overline{\mathrm{Y}}$ & $\begin{array}{l}\text { Nivomiting } \\
\text { Alopocis } \\
\text { Leulsepenia }\end{array}$ & $\mathrm{N}-2$ & $A$ \\
\hline $\begin{array}{l}\text { Takayanna T(A) } \\
2000\end{array}$ & $\mathrm{Y}$ & $\overline{\mathrm{NE}}$ & $\mathrm{Y}$ & $\overline{\mathrm{NL}}$ & $\overline{\mathrm{Y}}$ & $\begin{array}{l}\text { Nvomiting } \\
\text { WCC }\end{array}$ & NE & $\mathrm{C}$ \\
\hline $\begin{array}{l}\text { Tikaymama T (B) } \\
2000\end{array}$ & $\mathrm{Y}$ & $\overline{\mathrm{NE}}$ & $\mathrm{Y}$ & $\mathrm{NE}$ & $\bar{Y}$ & $\begin{array}{l}\text { Nvveniting } \\
\text { wec }\end{array}$ & $\mathrm{NE}$ & B \\
\hline $\begin{array}{l}\text { Trediro H } \\
1994\end{array}$ & $\mathrm{Y}$ & $\bar{Y}$ & $\mathbf{N}$ & NR & $\bar{Y}$ & $\begin{array}{l}\text { N.voniting } \\
\text { Leukupenia } \\
\text { Alkpecis }\end{array}$ & Nil reporied & $\mathrm{C}$ \\
\hline $\begin{array}{l}\text { Thwmas L } \\
2008\end{array}$ & $\mathrm{x}$ & $\bar{x}$ & $\bar{Y}$ & $\mathrm{Y}$ & $\bar{Y}$ & $\begin{array}{l}\text { Nivomiting } \\
\text { Akpocis } \\
\text { Levilsopenia }\end{array}$ & $\mathrm{N}-15$ & $\begin{array}{l}\text { No grib- } \\
\text { group }\end{array}$ \\
\hline $\begin{array}{l}\text { Yaughin CB } \\
1988\end{array}$ & $\mathrm{Y}$ & $\overline{\mathrm{Y}}$ & $\bar{Y}$ & $\mathrm{Y}$ & $\bar{Y}$ & $\begin{array}{l}\text { Nivomiting } \\
\text { Abpecis } \\
\text { Laulsopenia }\end{array}$ & $\mathrm{N}-1$ & $A$ \\
\hline
\end{tabular}

NR - Not reported, $\mathrm{NE}$ - Not exiractible 
Figure 3. Summary of included trials with extractable data Q2

\begin{tabular}{|c|c|c|c|c|c|c|c|c|}
\hline Trial ID & $\begin{array}{l}\text { Survisul } \\
\text { Curve }\end{array}$ & $\begin{array}{l}\text { Median } \\
\text { survival }\end{array}$ & $\begin{array}{l}\text { TTP } \\
\text { Curve }\end{array}$ & $\begin{array}{l}\text { Medlan } \\
\text { TTP }\end{array}$ & $\begin{array}{l}\text { Overull } \\
\text { response }\end{array}$ & $\begin{array}{l}\text { Grade IIVIV } \\
\text { Toxdelty }\end{array}$ & $\begin{array}{l}\text { Treatnacnt } \\
\text { related } \\
\text { deaths }\end{array}$ & $\begin{array}{l}\text { Sub- } \\
\text { group }\end{array}$ \\
\hline \multicolumn{9}{|c|}{ Q2. Reginen A versus Regimen C } \\
\hline $\begin{array}{l}\text { Alunian DL, } \\
1974(3)\end{array}$ & $\mathrm{Y}$ & $Y$ & $\mathrm{NR}$ & NR & $\mathrm{NR}$ & NR & Nil reported & $\Xi$ \\
\hline $\begin{array}{l}\text { ANZBCTG } \\
2001\end{array}$ & $\overline{\mathrm{NR}}$ & NR & NR & NRR & $\bar{Y}$ & $\begin{array}{l}\text { Nvomiting } \\
\text { Lentsopenin } \\
\text { Alcpecis }\end{array}$ & Mil reportod & $\bar{E}$ \\
\hline $\begin{array}{l}\text { Bistog J } \\
\text { 19y9 }\end{array}$ & $\mathrm{Y}$ & $\mathrm{Y}$ & $\mathrm{Y}$ & $\mathrm{T}$ & $\mathrm{Y}$ & $\begin{array}{l}\text { Wvoctiling } \\
\text { Alepscia } \\
\text { Letrikapanie }\end{array}$ & $\mathrm{NR}$ & $F$ \\
\hline $\begin{array}{l}\text { Donndteate J } \\
2002\end{array}$ & $\mathrm{Y}$ & $\mathrm{Y}$ & $\mathrm{Y}$ & $\mathrm{Y}$ & $\mathrm{Y}$ & $\begin{array}{l}\text { Nwoniting } \\
\text { Nextropenis } \\
\text { Alcpecia }\end{array}$ & $\mathrm{N}-6$ & $\mathrm{I}$ \\
\hline $\begin{array}{l}\text { Cantilles JP } \\
1976\end{array}$ & $\bar{Y}$ & $\bar{Y}$ & NR & NR & $\mathrm{Y}$ & Letukopaiı & Nil reputal & $\mathrm{G}$ \\
\hline $\begin{array}{l}\text { Eagan RT } \\
1976\end{array}$ & NR & NR & NR & NR & $\mathrm{Y}$ & $\begin{array}{l}\text { Leutiopenia } \\
\text { Alepreia }\end{array}$ & $\mathrm{N}-1$ & G \\
\hline $\begin{array}{l}\text { Exssi M } \\
1997\end{array}$ & $\mathrm{SR}$ & $\bar{Y}$ & $\mathrm{NR}$ & NR & $\bar{Y}$ & NR & $\mathrm{x}-1$ & 0 \\
\hline $\begin{array}{l}\text { Frast S } \\
1993\end{array}$ & $\mathrm{Y}$ & $\mathrm{Y}$ & $\mathrm{NR}$ & $\mathrm{V}$ & $\bar{Y}$ & NE & Xil repret & $\mathbb{R}$ \\
\hline $\begin{array}{l}\text { Heidemena E } \\
2002\end{array}$ & $\bar{Y}$ & $\bar{Y}$ & $Y$ & $Y$ & $Y$ & $\begin{array}{l}\text { Nwoniting } \\
\text { Alcpecia }\end{array}$ & Nil reported & $\mathrm{NA}$ \\
\hline $\begin{array}{l}\text { Hoogttraten B } \\
\text { (A) } \\
1976\end{array}$ & $\mathrm{NR}$ & NR & NR & NR & $\bar{Y}$ & $\begin{array}{l}\text { Letikopeatus } \\
\text { Alcpecia }\end{array}$ & $\overline{N E}$ & $\bar{E}$ \\
\hline $\begin{array}{l}\text { Iloogstraten B } \\
\text { (B) } \\
1976\end{array}$ & NR & NR & NR & NR & $Y$ & $\begin{array}{l}\text { Lonliaponis } \\
\text { Alepecia }\end{array}$ & $\mathrm{NE}$ & $\mathbb{E}$ \\
\hline $\begin{array}{l}\text { Icli F } \\
20015\end{array}$ & $\mathrm{Y}$ & $Y$ & $\bar{Y}$ & $\mathrm{Y}$ & $Y$ & $\begin{array}{l}\text { Nansos } \\
\text { Letulapen ix }\end{array}$ & $\mathrm{N}=6$ & $\mathrm{~F}$ \\
\hline $\begin{array}{l}\text { Nabholtz ЛM } \\
1999\end{array}$ & $\bar{Y}$ & $\bar{\gamma}$ & $Y$ & $\gamma$ & $\mathrm{Y}$ & NRR & $\mathrm{N}=7$ & F \\
\hline $\begin{array}{l}O^{\prime} \text { Shaughntssy J } \\
2001\end{array}$ & $\mathrm{Y}$ & $Y$ & $\mathrm{Y}$ & $Y$ & $\mathrm{Y}$ & $\begin{array}{l}\text { Nwoeniting } \\
\text { Alcpecis } \\
\text { Neutrapeniz }\end{array}$ & $x=3$ & 0 \\
\hline $\begin{array}{l}\text { Sjostram J } \\
\text { 1999 }\end{array}$ & $\bar{Y}$ & $\bar{\gamma}$ & $Y$ & $\gamma$ & $\mathrm{Y}$ & $\begin{array}{l}\text { Nausea } \\
\text { Alcpecia }\end{array}$ & $\lambda=4$ & $F$ \\
\hline $\begin{array}{l}\text { Slocklat M } \\
2006\end{array}$ & $\mathrm{Y}$ & $Y$ & $\mathrm{Y}$ & $\mathrm{Y}$ & $Y$ & $\begin{array}{l}\text { Nextropenis: } \\
\text { Vumizing } \\
\text { Alcpecia }\end{array}$ & Xil reported & 0 \\
\hline $\begin{array}{l}\text { Venturine } \Omega(\Lambda) \\
2000\end{array}$ & NR & $\bar{Y}$ & NR & $\bar{Y}$ & $\bar{Y}$ & $\begin{array}{l}\text { Letukapair } \\
\text { Alcpecis. }\end{array}$ & Mil rqpurtol & $\mathrm{C}$ \\
\hline $\begin{array}{l}\text { Venturine } A(B) \\
20000\end{array}$ & $\mathrm{NR}$ & $Y$ & $\mathrm{NR}$ & $\mathrm{Y}$ & $Y$ & $\begin{array}{l}\text { Letisopenia } \\
\text { Alcpecia }\end{array}$ & Nil repoted & $G$ \\
\hline
\end{tabular}

NR - Nat reperted, NE - Net exis actzólc

\section{Risk of bias in included studies}

Each study was reviewed according to its design and how the study was conducted to assess the potential for bias. Trial quality was assessed using the Cochrane Risk of Bias tables. This assessment was done retrospectively in this update for all 43 trials (48 comparisons). The items assessed were:

- Sequence generation

- Allocation concealment

- Incomplete outcome data

- Selective outcome reporting
Blinding was not assessed. Given the nature of the interventions used in the management of breast cancer it is not possible, nor practical, to expect blinding of the intervention or outcome assessment.

It was not possible to accurately assess the method of randomisation or allocation concealment used in most studies due to a lack of information in the published articles. Please refer to Figure 4 
Figure 4. Methodological quality graph: review authors' judgements about each methodological quality item presented as percentages across all included studies.

Random sequence generation (selection bias)

Allocation concealment (selection bias)

Incomplete outcome data (attrition bias): All outcomes

Selective reporting (reporting bias)
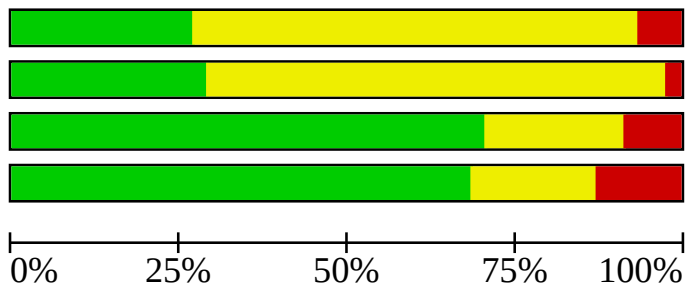

Low risk of bias

Unclear risk of bias

High risk of bias

\section{Effects of interventions}

For ratios of treatment effects for time-to-event outcomes HRs less than 1.0 favour combination regimens and values greater than 1.0 favour the control group (single drug chemotherapy).

For ratios of treatment effects for response and toxicity RRs greater than 1.00 favour combination regimens.

When interpreting the plots for each question and subgroup, readers may want to refer to the summary of included trials (Figure
5, Figure 6, Figure 2and Figure 3), particularly given the variety of the combination regimens assessed.

A total of 9742 women were randomised to 43 eligible trials (48 comparisons). Of these, the majority had histologically-confirmed metastatic breast cancer, with 5354 (55\%) women receiving firstline chemotherapy. Of the women randomised, data were available for overall survival for $82 \%$, response for $93 \%$ and time to progression for $67 \%$. 
Figure 5. Summary of regimens $Q 1$

\begin{tabular}{|c|c|c|c|c|}
\hline Trial ID & $\begin{array}{l}\text { Arm 1 } \\
\text { (single) }\end{array}$ & $\begin{array}{l}\text { Arm } 2 \\
\text { (combined) }\end{array}$ & $\begin{array}{l}\% \text { Firstline } \\
\text { for MBC }\end{array}$ & Accrual $^{\circ}$ \\
\hline $\begin{array}{l}\text { Ahmann DL } \\
1974 \text { (1) }\end{array}$ & $\mathrm{CCNL}^{-}$ & $\mathrm{F}+\mathrm{C}+\mathrm{P}+\mathrm{i}-\mathrm{V}^{1}$ & $100 \%$ & 13 \\
\hline $\begin{array}{l}\text { Ahmann DL } \\
1974 \text { (2) }\end{array}$ & I & $\mathrm{F}+\mathrm{C}+\mathrm{P}+l-\mathrm{V}^{1}$ & $100 \%$ & 40 \\
\hline $\begin{array}{l}\text { Albain K } \\
2004\end{array}$ & PACL & PACL + Gem & $100 \%$ & 529 \\
\hline $\begin{array}{l}\text { Andersson } \\
1986\end{array}$ & A & $\mathrm{A}+\mathrm{MMC}$ & $22.5 \%$ & 89 \\
\hline $\begin{array}{l}\text { Berrutti D } \\
2002\end{array}$ & $\mathrm{E}$ & $\mathrm{E}+\mathrm{CDDP}$ & $100 \%$ & 185 \\
\hline $\begin{array}{l}\text { Carmo-Periern J } \\
1980\end{array}$ & F & CMFVP & $100 \%$ & 135 \\
\hline $\begin{array}{l}\text { Fjlerisen B } \\
2004\end{array}$ & $\bar{F}$ & $\mathrm{~F}+\mathrm{V}^{3}$ & $100 \%$ & 387 \\
\hline $\begin{array}{l}\text { Falksong } \\
1990\end{array}$ & CTX & CMFVP & $100 \%$ & 111 \\
\hline $\begin{array}{l}\text { French Epi Group (A) } \\
|99|\end{array}$ & $\bar{E}$ & FEC 50 & $100 \%$ & 275 \\
\hline $\begin{array}{l}\text { French Epri Group (B) } \\
1991\end{array}$ & $\bar{E}$ & FEC 75 & $100 \%$ & 277 \\
\hline Geicam 2007 & $\mathrm{v}^{2}$ & $V^{3}$ IGem & $36 \%$ & 252 \\
\hline $\begin{array}{l}\text { Gunderson S } \\
1986\end{array}$ & A & $V^{\prime}+A+C$ & $100 \%$ & 128 \\
\hline $\begin{array}{l}\text { Heidamaru E } \\
2004\end{array}$ & $M$ & $\mathrm{M}+\mathrm{TXT}$ & $100 \%$ & 179 \\
\hline $\begin{array}{l}\text { Ingle J } \\
1985\end{array}$ & $A$ & $A+$ MTL & $100 \%$ & 158 \\
\hline $\begin{array}{l}\text { Ingle J } \\
1989\end{array}$ & $\Lambda$ & $\Lambda+V^{1}+M M C$ & $100 \%$ & 185 \\
\hline $\begin{array}{l}\text { Jcensum H } \\
1998\end{array}$ & $\bar{E}$ & $\mathrm{E}+\mathrm{C}+\mathrm{F}$ & $100 \%$ & 303 \\
\hline $\begin{array}{l}\text { Mourisden H } \\
1977\end{array}$ & C? & CMFVP & $100 \%$ & 55 \\
\hline $\begin{array}{l}\text { Nielsen D } \\
2000\end{array}$ & E & $\mathrm{E}+\mathrm{CDDP}$ & $100 \%$ & 155 \\
\hline $\begin{array}{l}\text { Nielsm D } \\
1990\end{array}$ & F & $\mathrm{F},+\mathrm{V}^{2}$ & $48 \%$ & 14.3 \\
\hline $\begin{array}{l}\text { Nomris B } \\
2000\end{array}$ & A & $A+V^{3}$ & $75 \%$ & 303 \\
\hline $\begin{array}{l}\text { O'Shaughmessy J } \\
2002\end{array}$ & TXT & TXT +CCB & $3.3 \%$ & 511 \\
\hline $\begin{array}{l}\text { Rubens RD } \\
1975\end{array}$ & $\mathrm{C}$ & $\mathrm{CMFV}^{2} \mathrm{P}$ & $100 \%$ & 99 \\
\hline $\begin{array}{l}\text { Sledge } G(A) \\
2003\end{array}$ & A & $\begin{array}{l}\mathrm{A}+ \\
\mathrm{PACL}\end{array}$ & $71 \%$ & 367 \\
\hline $\begin{array}{l}\text { Sledge G (B) } \\
2003\end{array}$ & PACL & $\begin{array}{l}\text { At } \\
\text { PACL }\end{array}$ & $51 \%$ & 364 \\
\hline $\begin{array}{l}\text { Stciner R } \\
1983\end{array}$ & A & $A+V^{\prime}$ & $100 \%$ & 119 \\
\hline $\begin{array}{l}\text { Takayama T }(\Lambda) \\
2000\end{array}$ & $\mathrm{~F}$ & $\Gamma+C$ & Unclear & 111 \\
\hline $\begin{array}{l}\text { Takayama T (B) } \\
2000\end{array}$ & $\mathrm{C}$ & $\Gamma । C$ & Unclear & 109 \\
\hline $\begin{array}{l}\text { Tashiro H } \\
1994\end{array}$ & FT & UFT + placebo & $86 \%$ & 60 \\
\hline $\begin{array}{l}\text { Thomas E } \\
2008\end{array}$ & IX & $\mathrm{IX}+\mathrm{CCB}$ & $85 \%$ & 752 \\
\hline
\end{tabular}


Figure 5. (Continued)

\begin{tabular}{|l|l|l|l|l|}
\hline $\begin{array}{l}\text { Thomas E } \\
2008\end{array}$ & IX & IX + CCB & $85 \%$ & 752 \\
\hline $\begin{array}{l}\text { Vaughn CB } \\
1988\end{array}$ & A & A+ETO & Unclcar & 122 \\
\hline
\end{tabular}


Figure 6. Summary of regimens $\mathrm{Q2}$

\begin{tabular}{|c|c|c|c|c|}
\hline Trial ID & $\begin{array}{l}\text { Arm } 1 \\
\text { (single) }\end{array}$ & $\begin{array}{l}\text { Arm } 2 \\
\text { (combined) }\end{array}$ & $\begin{array}{l}\text { \% Firstline } \\
\text { for MBC }\end{array}$ & Accrual ${ }^{\star}$ \\
\hline $\begin{array}{l}\text { Ahmann DL, } \\
1974(3)\end{array}$ & $\mathrm{A}$ & $\mathrm{F}+\mathrm{C}+\mathrm{P}+\mathrm{V}^{-1}$ & $100 \%$ & 48 \\
\hline $\begin{array}{l}\text { A VZBCTG } \\
1994\end{array}$ & MZA & CMFP & $100 \%$ & 391 \\
\hline $\begin{array}{l}\text { Bishop J } \\
1999 \\
\end{array}$ & PACT. & CMFP & $100 \%$ & 209 \\
\hline $\begin{array}{l}\text { Bonnetterre I } \\
2002\end{array}$ & $\mathrm{TXI}^{\prime}$ & $F+V^{J}$ & $34 \%$ & 178 \\
\hline $\begin{array}{l}\text { Canellos JP } \\
1976\end{array}$ & L-PAM & CMF & $100 \%$ & 184 \\
\hline $\begin{array}{l}\text { Eagen RT } \\
1976\end{array}$ & ETO & $V^{1}+A$ & $\begin{array}{l}\text { Assumed } 2^{\text {rh }} \\
\text { line }\end{array}$ & 39 \\
\hline $\begin{array}{l}\text { Erksi M } \\
1997\end{array}$ & ETO & FAC & $48 \%$ & 60 \\
\hline $\begin{array}{l}\text { Fraser S } \\
1093\end{array}$ & $E$ & CMF & Unclear & 40 \\
\hline $\begin{array}{l}\text { Heidemann E } \\
2002\end{array}$ & $\mathrm{MZA}$ & FEC & $100 \%$ & 200 \\
\hline $\begin{array}{l}\text { IIoogstraten D (A) } \\
1976\end{array}$ & $A$ & $\begin{array}{l}\text { CMrVP } \\
\text { (Intermittent) }\end{array}$ & $100 \%$ & 177 \\
\hline $\begin{array}{l}\text { Hougstraten B (B) } \\
1976\end{array}$ & $\bar{A}$ & $\begin{array}{l}\text { CMFVP- } \\
\text { (Weekly) }\end{array}$ & $100 \%$ & 185 \\
\hline $\begin{array}{l}\text { Icli F } \\
2002\end{array}$ & PACL & ETO-CDDP & $20 \%$ & 201 \\
\hline $\begin{array}{l}\text { Nabholtz JM } \\
1999\end{array}$ & TXI & $\mathrm{MMC}+\mathrm{V}^{2}$ & $38 \%$ & 392 \\
\hline $\begin{array}{l}\text { O'Shaughnessy J } \\
2001\end{array}$ & $\mathrm{CCB}$ & $\mathrm{CMI}$ & $100 \%$ & 95 \\
\hline $\begin{array}{l}\text { Sjostron J } \\
1999\end{array}$ & TXT & $\mathrm{M}+\mathrm{F}$ & $\begin{array}{l}\text { First and } \\
\text { second line }\end{array}$ & 283 \\
\hline $\begin{array}{l}\text { Stockler M } \\
2006\end{array}$ & $\mathrm{CCP}$ & CMF & $100 \%$ & 323 \\
\hline $\begin{array}{l}\text { Venturino } A \\
2000\end{array}$ & $v^{3}$ & LEUC+F & $\begin{array}{l}\mathrm{N} \text {-all second } \\
\text { line }\end{array}$ & 66 \\
\hline $\begin{array}{l}\text { Venturino } A \\
2000\end{array}$ & $v^{3}$ & $\mathrm{MZA}+\mathrm{LELC}+\mathrm{F}$ & $\begin{array}{l}\mathrm{N} \text {-all second } \\
\text { line }\end{array}$ & 66 \\
\hline
\end{tabular}

Includes numbers accrued and random ised where uvailuble or ussessuble numbers if randomised not provided

\section{Abbreviations}

A -Doxorubicin; C-Cyclophosphamide; CCB - Capecitabine; CCNU - lomustine; CDDP - cisplatin; CMFVP-cyclophcsphamide, methotrexate, flusrouracil; vincristine ; prednisone: DBD -mitolactol; Fepirubicin; Ecyclof - epirubicin, cyclophospham ide, lluorouracil; ETO - etoposide/VP-16; F fluorouracil, I - ifosamide; Iphosphamide (cyclophosphamide analogue); Gem Gemcitabine; LEUC leucovorin; :-PAM - L-phenylalanine mustard/Melphalan; M - methotrexate; MMC - mitomycin; MTL - mitolactol MZA - miloxantrune; O-ouphorectomy; P-prednisone prednisulone: PACLpaclitaxel; PLD - Peglyated liposomal doxorubicin, "TXT - docetaxel; F'T-5 Flouro - 1 (Tetrahydro2furyl) - uracil (analogue of $5 \mathrm{FU}$ ) -Tegafur; "UFT - tegafur, uracil; $\mathrm{V}^{1}$ - vincristine; $\mathrm{V}^{2}$ - vinblastine; $v^{3}$ - vinorelhine; $V^{-1}$ - vilixdesine 
Overall survival Sufficient data were available from 36 of the 48 comparisons (reporting an estimated 5156 deaths in 7147 women) to enable a HR for overall survival for a single chemotherapy agent versus combination regimens to be calculated. There was a statistically significant difference in survival, favouring combination regimens, with a HR of $0.88(95 \% \mathrm{Cl} 0.83$ to 0.93 , $\mathrm{p}<0.00001)$. There was no statistically significant heterogeneity across the trials (chi squared $=48.56,35 \mathrm{df}, \mathrm{p}=0.06$ ).

The results for overall survival were similar when the analysis was limited to the 21 trials in women receiving first-line chemotherapy involving an estimated 2782 deaths in 3982 women (HR 0.88, 95\% $\mathrm{Cl} 0.81$ to $0.94, \mathrm{p}=0.0005$ ) however there was statistically significant heterogeneity (chi squared $=39.06,20 \mathrm{df}, p=0.007,12=49 \%$ ).

Question 1 - Regimen A (single) versus Regimen A +other Twenty five of the 28 eligible comparisons provided information on survival for question 1 (reporting an estimated 3647 deaths in 4935 women). There was a statistically significant difference in survival, favouring combination regimens, with a $\mathrm{HR}$ of $0.88(95 \% \mathrm{Cl} 0.83$ to $0.94, \mathrm{p}=$ 0.0002 ). There was no significant heterogeneity across the trials (chi squared $=27.04,24 \mathrm{df}, \mathrm{p}=0.30$ ).

Question 2 - Regimen A (single) versus Regimen C Eleven of the 18 eligible comparisons provided information on overall survival for Question 2. There was no statistically significant difference in survival between the regimens with a HR of $0.86(95 \% \mathrm{Cl} 0.78$ to $0.96, P=0.005$ ). There was statistically significant heterogeneity (chi squared $=21.42,10 \mathrm{df}, \mathrm{p}=0.02 ; \mathrm{I}^{2}=53 \%$ ).

Single agent taxane versus all combinations Eight comparisons (2646 women), provided information on overall survival where a single agent taxane was compared to a combination regimen containing any chemotherapy agent. There was a statistically significant benefit in favour of the combination regimens with a HR of 0.82 ( $95 \% \mathrm{Cl} 0.75$ to $0.89, \mathrm{P}<0.00001)$. There was no evidence of heterogeneity (chi squared $=7.40,7 \mathrm{df}, \mathrm{p}=0.39$ ).

Single agent anthracycline versus all combinations Sixteen comparisons (2985 women), provided information on overall survival where a single agent anthracycline was compared to a combination regimen containing any chemotherapy agent. There was no statistically significant benefit between the groups with a HR of 0.94 (95\% Cl 0.86 to $1.02, P=0.15)$. There was no evidence of heterogeneity (chi squared $=8.14,15 \mathrm{df}, \mathrm{p}=0.92$ ).

Time to progression (TTP) Sufficient data were available from 27 comparisons (reporting an estimated 5480 events in 6501 women) to enable a HR for time to progression to be calculated. There was a statistically significant difference in favour of the combination regimens with a HR of $0.78(95 \% \mathrm{Cl} 0.74$ to $0.82, \mathrm{p}<0.00001)$. There was statisticially significant heterogeneity for this outcome (chi squared $=71.88,26 \mathrm{df}, \mathrm{p}<0.00001 ; \mathrm{I}^{2}=64 \%$ ).

Limiting the analysis to the 13 comparisons of first-line chemotherapy,with an estimated 2558 deaths in 3201 women produced similar results. There was a statistically significant benefit in favour of the combination regimens with a HR of 0.87 ( $95 \% \mathrm{Cl} 0.81$ to $0.94, p=0.0003$ ). There was significant heterogeneity (chi squared $=26.36,12 \mathrm{df}, \mathrm{p}=0.01 ; \mathrm{I}^{2}=54 \%$ ).

Question 1 - Regimen A (single) versus Regimen A +other Eighteen of the 30 comparisons provided information on time to progression for question 1. Data from the 4521 women randomised to these comparisons yielded statistically significant differences in favour of the combination regimens over single-agent treatment with a HR of 0.76 ( $95 \% \mathrm{Cl} 0.71$ to $0.80, p<0.00001)$. There was no evidence of significant heterogeneity (chi squared $=20.96,17 \mathrm{df}, \mathrm{p}=0.23$ ).

\section{Question 2 - Regimen A (single) versus Regimen C}

Nine of the 18 comparisons provided information on time to progression for question 2. Data from the 1980 women randomised to these comparisons showed a statistically significant difference favouring combination regimens over single-agent treatment with a HR of $0.85(95 \% \mathrm{Cl} 0.78$ to $0.93, \mathrm{p}=0.0003)$. There was significant heterogeneity (chi squared $=46.56,8 \mathrm{df}, \mathrm{p}<0.00001 ; \mathrm{I}^{2}=83 \%$ ).

\section{Single agent taxane versus all combinations}

Seven comparisons (2302 women) provided information on time to progression for single agent taxane compared to a combination regimen containing any chemotherapy agent. There was a statistically significant benefit in favour of the combination regimens with a HR of $0.72(95 \% \mathrm{Cl} 0.67$ to $0.79, \mathrm{P}<0.00001)$. There was significant heterogeneity (chi squared $=27.74,6 \mathrm{df}, \mathrm{p}=0.0001$; $12=78 \%)$.

\section{Single agent anthracycline versus all combinations}

Thirteen comparisons (2352 women), provided information on time to progression where a single agent anthracycline was compared with a combination regimen containing any chemotherapy agent. There was a statistically significant difference in favour of the combination regimens with a HR of $0.82(95 \% \mathrm{Cl} 0.75$ to 0.89 , $\mathrm{P}<0.00001$ ). There was no evidence of heterogeneity (chi squared $=13.19,12 \mathrm{df}, \mathrm{p}=0.36$ ).

\section{Response}

Data from 46 of the 48 comparisons (9044 assessable women) were available to enable a relative risk for overall tumour response to be calculated. It is recognised that there were some differences in the definition of response across (but not within) trials. There was a statistically significant difference in favour of combination regimens with a RR of $1.29(95 \% \mathrm{Cl} 1.14$ to $1.45, \mathrm{p}<0.0001)$ for assessable patients. There was significant heterogeneity across trials (chi squared $=177.93,45 \mathrm{df}, \mathrm{p}<0.00001, \mathrm{l}^{2}=75 \%$ ). Similarly, if the analysis was limited to the 4767 assessable women in the 25 first-line comparisons, there was a statistically significant difference in favour of combination regimens with a RR of 1.35 $(95 \% \mathrm{Cl} 1.16$ to $1.56, \mathrm{p}<0.0001)$. There was significant heterogeneity across trials (chi squared $=86.05, \mathrm{df} 24, \mathrm{p}<0.00001,1^{2}=72 \%$ ).

Question 1 - Regimen A (single) versus Regimen A +other Twenty nine of 30 comparisons eligible for question 1 provided information on response. Based on the 6102 assessable women, there was a statistically significant difference in favour of combination regimens with a RR of $1.37(95 \% \mathrm{Cl} 1.20$ to $1.56, \mathrm{p}<0.00001)$. Significant heterogeneity was seen across the trials (chi squared $\left.=99.40,28 \mathrm{df}, \mathrm{p}<0.00001,1^{2}=72 \%\right)$.

\section{Question 2 - Regimen A (single) versus Regimen C}

Seventeen of 18 comparisons eligible for question 2 provided information on response. Based on the 2942 assessable women, there was no statistically significant difference between either regimens with the RR being $1.13(95 \% \mathrm{Cl} 0.87$ to $1.47, \mathrm{p}=0.37)$. Significant heterogeneity was seen across the trials (chi squared $\left.=74.69,16 \mathrm{df}, \mathrm{p}<0.00001,1^{2}=79 \%\right)$. 


\section{Single agent taxane versus all combinations}

Eight comparisons (2578 women), provided information on response for single agent taxane compared to a combination regimen containing any chemotherapy agent. There was no statistically significant benefit in between regimens with a RR 1.03 ( $95 \% \mathrm{Cl} 0.72$ to $1.48, \mathrm{P}=0.87$ ). There was evidence of heterogeneity (chi squared $=65.32,7 \mathrm{df}, \mathrm{p}<0.00001,1^{2}=89 \%$ ).

\section{Single agent anthracycline versus all combinations}

Twenty comparisons (3798 women), provided information on response where a single agent anthracycline was compared with a combination regimen containing any chemotherapy agent. There was a modest although statistically significant difference in favour of the combination regimens with a RR of $1.19(95 \% \mathrm{Cl} 1.06$ to $1.34, \mathrm{P}$ $=0.003$ ). There was evidence of heterogeneity (chi squared $=38.87$, $\left.19 \mathrm{df}, \mathrm{p}=0.005,1^{2}=51 \%\right)$.

Toxicity Of the 48 eligible comparisons, 36 provided some data on grade $3 / 4$ toxicities of interest (WCC, alopecia and nausea and vomiting). Please refer to Figure 2; Figure 3. Of these, 35 comparisons reported on WCC (7810 assessable women), 21 comparisons on alopecia (4818 assessable women) and 30 comparisons on nausea and vomiting (7487 assessable women).

Overall, combination chemotherapy was associated with a statistically significant detrimental effect on WCC with a RR of $1.49(95 \% \mathrm{Cl} 1.24$ to $1.79, \mathrm{p}<0.0001)$. There was evidence of heterogeneity (chi squared $=607.34,34 \mathrm{df}, \mathrm{p}<0.00001,12=94 \%$ )

There was no statistically significant difference between the groups for alopecia (RR 1.12, 95\% Cl 0.81 to $1.54, p=0.48$ ) or for nausea and vomiting ( $\mathrm{RR} 1.29,95 \% \mathrm{Cl} 0.96$ to $1.74, \mathrm{p}=0.09$ ). There was evidence of heterogeneity (chi squared $=394.44,20 \mathrm{df}, \mathrm{p}<0.00001,1^{2}=95 \%$ ) and (chi squared $=172.40,29 \mathrm{df}, \mathrm{p}<0.00001,1^{2}=83 \%$ ) respectively.

There was marked evidence of heterogeneity for overall toxicity and analysis of toxicity data addressing questions 1 and 2 .

Question 1 - Regimen A (single) versus Regimen A tother For question 1, 21 comparisons includeding data on WCC (5164 assessable patients), 11 reported on alopecia (2778 assessable patients) and 20 reported on nausea and vomiting (5149 assessable patients). Based on these trials combination chemotherapy was associated with a statistically significant detrimental effect on WCC (RR 1.69, $\mathrm{Cl} 1.30$ to 2.20, $\mathrm{p}=0.0001$ ) and increased alopecia (RR 2.18, $95 \% \mathrm{Cl} 1.10$ to $4.30, \mathrm{p}=0.031$ ). There was no statistically significant difference between single agent and combination chemotherapy for nausea and vomiting (RR $1.16,95 \% \mathrm{Cl} 0.81$ to $1.65, \mathrm{p}=0.41$ ).

\section{Question 2 - Regimen A (single) versus Regimen C}

For question 2, 14 comparisons reported on WCC (2646 assessable patients), 10 comparisons reported on alopecia (2040 assessable patients), and 10 comparisons (2338 assessable patients) reported on nausea and vomiting. There was no statistically significant difference for WCC (OR 1.27, 95\% Cl 0.93 to $1.74, \mathrm{p}=0.13$ ). Combination chemotherapy was associated with significantly more nausea and vomiting toxicity ( $R R 1.79,95 \% \mathrm{Cl} 0.93$ to $3.43, \mathrm{p}=0.08$ ). For alopecia however, single-agent chemotherapy was associated with more toxicity (RR $0.63,95 \% \mathrm{Cl} 0.31$ to 1.27 ) but this did not reach significance.

\section{Treatment-related death}

Twenty four comparisons reported deaths during their respective trial periods. These were variously defined but were included in this review if the trial reported death due to the toxicity of the drug and not to disease progression, "toxic death", "lethal toxicity" or "treatment related death". Seventeen comparisons reported data for this outcome for question 1 and seven comparisons for question 2.

For trials reporting treatment related or sudden/unexplained death, 57 deaths occurred in the single agent arms and 53 in the combination arms. There was no statistically significant difference between the single agent and the combination regimens overall ( $R R$ 1.09, 95\% Cl 0.72 to $1.66, p=0.83$ ). There was no evidence of heterogeneity.

Of the trials reporting treatment-related death in their single-agent arms, eleven comparisons (Andersson M 1986; Berruti D 2002; Ejlertsen B 2004; Ingle J 1985; Ingle J 1989; Nielson D 1990; Nielsen D 2000; Norris B 2000; Sledge G(A) 2003; Steiner R 1983; Vaughn CB 1988) involved the use of anthracyclines (29 deaths), and seven (Albain KS 2004; Bonneterre J 2002; Icli F 2005; Nabholtz JM 1999; O'Shaughnessy J 2002; Sjostrom J 1999; Sledge G(B) 2003) involved trials of taxanes (18 deaths).

There was also no difference when single-agent chemotherapy was tested against combination therapy not containing that agent (RR $0.91,95 \% \mathrm{Cl} 0.41$ to $2.04, \mathrm{p}=0.83$ ), or when the single-agent was also used in the combination regimen ( $\mathrm{RR} 1.14,95 \% \mathrm{Cl} 0.69$ to $1.88, \mathrm{p}=$ $0.61)$.

Quality of life (QoL) A total of 11 trials (yielding 12 comparisons) (Albain KS 2004; ANZBCTG 2001; Bishop J 1999; Fraser S 1993; Heidemann E 2002; Joensuu H 1998; Nabholtz JM 1999; Norris B 2000; O'Shaughnessy J 2002; Sledge G(A) 2003; Sledge G(B) 2003; Sjostrom J 1999) had QoL as a major end point (Table 1).

A variety of QoL instruments were used including: LASA, Spitzer, Nottingham Health Profile (NHP), WHO Analogue and Satisfaction Scales Questionnaire, Brunners Score, Rotterdam Symptom Checklist (RSCL), FACT-B and the EORTC QLQ-C30 Global Health Score. The QoL indicators for patients typically assessed were mood, pain, nausea and vomiting, diarrhoea, hair loss, loss of appetite and social functioning. Two trials (Bishop J 1999: ANZBCTG 2001) also rated clinician assessment of the patients QoL using the Spitzer quality-of-life index.

Five trials reported some statistically significant differences between the treatment arms. Only one trial (Albain KS 2004) reported a statistically significant advantage in global QoL. Participants in this trial recorded a significantly and consistently better global QoL for the single drug arm (paclitaxel). In two trials (Heidemann E 2002: Joensuu H 1998), better QoL was associated with single-agent chemotherapy. Heidemann 2002 reported that patients receiving mitoxantrone reported less hair loss, nausea and vomiting. Patients in the Joensuu 1998 trial treated with epirubicin showed no difference in psychological dimensions of QoL but reported less physical distress and nausea at 6 months and at other assessable points during the trial. Two trials (Nabholtz JM 1999: ANZBCTG 2001) reported results favouring both single and combination regimens. Nabholtz JM (1999) found a significant difference in QoL for patients in the docetaxel arm in terms of nausea and vomiting and loss of appetite but for patients in the mitomycin plus vinblastine arm for role and social functioning. The authors also concluded that as patients with the poorest health did not complete the QoL questionnaires, QoL might be 
overestimated in both groups. In ANBCTG (2001) patients in the combination arm (CMFP) reported better QoL for the first three months for pain, mood, and nausea and vomiting but worse QoL for hair loss. Results were similar overall. Although O'Shaughnessy J 2002 found no statistically significant differences, there was a trend towards less deterioration in the global score for the combination arm (docetaxel and capecetibine).

\section{Subgroup analyses}

The eligible studies identified involved a variety of different drugs, doses and regimens. Prior to pooling the results of studies, and blind to the results of individual studies, two medical oncologists (JS and NW) who were not involved in assessing eligibility or data extraction, were asked to determine a clinically meaningful way of grouping studies relative to the number and quality of eligible trials. They were provided with details of the drugs, dosages and schedules compared in each trial.

Four sub-groups relating to question 1 were subsequently analysed and three sub-groups relating to question 2 .

Question 1. Addition of a drug to a chemotherapy regimen: Twenty eight comparisons compared a single drug with a combination regimen that included the same drug. An analysis was done for the pooled trials and by the following sub-groups.

I.Subgroup A: single anthracycline versus anthracycline plus other II.Subgroup B: single alkylating agent versus alkylating plus other III.Subgroup C: single antimetabolite agent versus antimetabolite plus other

IV.Subgroup D: single taxane agent versus taxane plus other

Sub Group A: single anthracycline versus anthracycline plus other Fifteen trials (16 comparisons) compared a single anthracycline with an anthracycline-containing regimen. Of these, 6 trials (7 comparisons) compared epirubicin with an epirubicin-containing regimen and 7 trials compare doxorubicin with a doxorubicincontaining regimen (Figure 5; Figure 2).

Overall survival

Data from fourteen comparisons reporting an estimated 2043 deaths in 2897 women, contributed to the calculation of a HR for overall survival. There was no evidence of a difference in favour of either regimen with a HR of $0.95(95 \% \mathrm{Cl} 0.87$ to $1.04, \mathrm{p}=0.25)$ and no heterogeneity (chi squared $=4.53,13 \mathrm{df}, \mathrm{p}=0.98$ ).

\section{Time to progression (TTP)}

Twelve comparisons reported on TTP. Of these, seven compared epirubicin with a epirubicin containing regimen and four compared doxorubicin with a doxorubicin containing regimen. The pooled data (from 2312 randomised women) showed a statistically significant difference between the regimens in favour of combination regimens with a HR of $0.82(95 \% \mathrm{Cl} 0.0 .75$ to 0.89 , $\mathrm{p}<0.00001$ ). There was no heterogeneity (chi squared $=11.46,11 \mathrm{df}$, $\mathrm{P}=0.41)$.

\section{Response}

For the 16 comparisons, there was a statistically significant difference between regimens for response in favour of the combination regimens with an RR of $1.15(95 \% \mathrm{Cl} 1.02$ to 1.31 , $p=0.03$ ). There was evidence of significant heterogeneity (chi squared $=31.87,15 \mathrm{df}, \mathrm{p}=0.007 ; \mathrm{I}^{2}=53 \%$ ).
Six comparisons compared a single alkylating agent with an alkylating-containing regimen.

\section{Overall survival}

Five comparisons (reporting an estimated 293 deaths in 375 women) enabled a HR for overall survival to be calculated. There was no evidence of a difference in favour of either regimen with a HR of $0.91(\mathrm{Cl} 0.72$ to $1.15, \mathrm{p}=0.45)$ and no heterogeneity (chi-squared $=1.31,4 \mathrm{df}, \mathrm{p}=0.86$ ).

Time to progression

Only one comparison (Takayama $T(B) 2000$ ) reported time to progression ( $\mathrm{HR}$ of $0.55, \mathrm{Cl} 0.36$ to $0.84, \mathrm{p}=0.006$ ).

\section{Response}

Five comparisons reported data on response with a statistically significant difference between regimens in favour of the combination regimens with an OR of $1.99(95 \% \mathrm{Cl} 1.31$ to $3.04, \mathrm{p}=$ 0.001 ). There was evidence of heterogeneity (chi-squared $=11.97,4$ $\mathrm{df}, \mathrm{p}=0.02$ ).

\section{Sub Group C: Single antimetabolite agent versus antimetabolite + other}

Three trials compared a single antimetabolite agent with an alkylating containing regimen. All three compared fluorouracil and a fluorouracil-containing regimen (see Figure 02 and 04).

\section{Overall survival}

The pooled survival data (reporting an estimated 196 deaths in 279 women) suggested a statistically significant benefit in favour of combination regimens with an $\mathrm{HR}$ of $0.62(\mathrm{Cl} 0.46$ to $0.82, \mathrm{p}=0.0009)$. There was significant heterogeneity (chi-squared $=8.15,2 \mathrm{df}, \mathrm{p}=$ 0.02 ). A HR of 0.62 represents a $38 \%$ reduction in the risk of death for women on the antimetabolite-containing regimen compared with women receiving the antimetabolite.

\section{Time to progression}

Only one trial (Takayama $T(A) 2000$ ) reported time to progression (HR of $0.84, \mathrm{Cl} 0.54$ to $1.28, \mathrm{p}=0.41$ ).

\section{Response}

The three trials reporting response suggest a statistically significant benefit in favour of the combination regimens (RR of $2.95,95 \% \mathrm{Cl}$ 1.92 to $9.62, P<0.00001$ ) with no heterogeneity (chi squared $=2.26$, $2 \mathrm{df}, \mathrm{p}=0.32, \mathrm{|} 2=11 \%)$.

\section{Sub Group D: Single taxane agent versus taxane + other}

Three comparisons reporting on 1407 randomised women, compared single taxane with a taxane-containing regimen (Albain KS 2004; O'Shaughnessy J 2002; Sledge G(B) 2003).

\section{Overall survival}

There was a significant difference in survival between the two arms (HR $0.81,95 \% \mathrm{Cl} 0.72$ to $0.91 \mathrm{p}=0.0004$ ) and no significant heterogeneity (chi squared $=2.10,2 \mathrm{df}, \mathrm{p}=0.35$ ).

\section{Time to progression (TTP)}

Two comparisons reported a statistically significant difference in favour of the combination arm for TTP (HR 0.69, 95\% $\mathrm{Cl} 0.61$ to 0.78 , $\mathrm{p}<0.00001$ ) (Albain KS 2004; O'Shaughnessy J 2002). There was no heterogeneity.

Response

\section{Sub Group B: Single alkylating agent versus alkylating + other}


The pooled data for response suggested a statistically significant benefit in favour of the combination regimen (RR of $1.52,95 \% \mathrm{Cl}$ 1.26 to $1.83, p<0.0001$ ) There was no evidence of heterogeneity (chisquared $=3.13,2 \mathrm{df}, \mathrm{p}=0.21$ )

2. Grouped by question 2: Regimen $\boldsymbol{A}$ versus $\boldsymbol{C}+$ other Eighteen comparisons compared a single drug with a combination regimen that did not include that drug. An analysis was done for the pooled trials and by the following sub-groups.

I.Subgroup E: single anthracycline agent versus non-anthracycline combination regimen

II.Subgroup F: single taxane versus non taxane, non-anthracycline containing combination regimen

III.Subgroup G: single non-taxane, non-anthracycline agent versus other combination regimen

Sub Group E: single anthracycline agent versus nonanthracycline combination regimen

Five comparisons compared a single antimetabolite agent with an alkylating containing regimen (see Figure 03).

\section{Overall survival}

The pooled survival data from two comparisons showed a statistically significant benefit in favour of the combination regimen ( $\mathrm{HR} 0.57, \mathrm{Cl} 0.33$ to $0.98, \mathrm{p}=0.04$ ). There was no heterogeneity (chi squared $=0.33,1 \mathrm{df}, \mathrm{p}=0.56$ )

Time to progression (TTP)

Only one trial (Fraser S 1993) reported time to progression (HR 0.52 $\mathrm{Cl} 0.26$ to $1.02, \mathrm{p}=0.06$ )

\section{Response}

Pooling data from four comparisons with 714 assessable women suggested a statistically significant benefit in favour of combination regimens ( $\mathrm{RR} 1.42, \mathrm{Cl} 1.15$ to $1.76, \mathrm{p}=0.001)$. There was no significant heterogeneity (chi squared $=2.78,3 \mathrm{df}, \mathrm{p}=0.43$ ).

Sub Group F: single taxane versus non taxane, non anthracycline containing combination regimen

Five trials compared a single taxane with non-taxane combination regimens (964 deaths of 1262 women).

\section{Overall survival}

The pooled data showed a statistically significant survival benefit for the combination regimens with a HR of $0.83(95 \% \mathrm{Cl} 0.73$ to 0.95 , $\mathrm{p}=0.005$ ) and no significant heterogeneity (chi squared $=5.20,4 \mathrm{df}$, $\mathrm{p}=0.27$ ).

\section{Time to progression (TTP)}

The pooled data for time-to-progression suggested a statistically significant benefit in favour of the combination regimen with an HR of 0.75 ( $95 \% \mathrm{Cl} 0.67$ to $0.84, p<0.00001)$. There was statistically significant heterogeneity (chi squared $=26.55,4 \mathrm{df}, \mathrm{p}<0.0001$; $\left.\mathrm{I}^{2}=85 \%\right)$.

\section{Response}

There was no difference between the groups for response (RR 0.80 , $\mathrm{Cl} 0.48$ to $1.33, \mathrm{p}=0.001$ ) with marked evidence of heterogeneity (chi squared $=32.11,4 \mathrm{df}, \mathrm{p}<0.00001 ;\left.\right|^{2}=88 \%$ ).

Sub Group G: single non-taxane, non-anthracycline agent versus other combination regimen

Overall survival
Survival data were available from three comparisons (Canellos GP 1976; O'Shaughnessy J 2001; Stockler M 2006) and showed no difference between the groups. There was statistically significant heterogeneity (chi squared $=10.18,2 \mathrm{df}, \mathrm{p}=0.006 ; \mathrm{I}^{2}=80 \%$ ).

\section{Time to progression (TTP)}

This outcome was reported by two comparisons (O'Shaughnessy J 2001; Stockler M 2006) and showed no difference between the groups. There was no significant heterogeneity.

Response There was no statistically significant advantage for either group in regard to tumour response with $\mathrm{RR}=1.28,95 \% \mathrm{Cl} 0.79$ to $2.08, p=0.31$ ) with evidence of significant heterogeneity (chi squared $=17.72$, df $\left.6, p=0.007 ;\left.\right|^{2}=66 \%\right)$.

\section{DISCUSSION}

It is generally thought that combining chemotherapy agents will result in regimens with superior tumour response and progression and improved overall survival.

The overall survival data analysed for this review, based on 7147 randomised women (5168 deaths), showed a statistically significant benefit for the use of combination chemotherapy regimens compared with single agent regimens (HR 0.88; 95\% $\mathrm{Cl} 0.83$ to $0.93, \mathrm{p}<0.00001)$. Results were very similar for overall survival for women receiving first-line chemotherapy and for the analysis of first-line treatment where the single agent was also included in the combination regimen. Where the single agent was not included in the combination regimen for first-line treatment there was no significant difference between the groups. However one trial, (Stockler M 2006), showed a survival benefit in favour of the single agent (capecitabine). It is possible that this was due to better tolerability (evident from QoL and toxicity data) than with CMF. Three times as many participants were still taking the single agent after twelve months in this trial.

Combination regimens also prevailed in the analysis of a single agent taxane versus any combination (HR $0.82 ; 95 \% \mathrm{Cl} 0.75$ to $0.89, p<0.00001)$, with no difference being shown between the groups for the analysis of single agent anthracycline. The failure to show a difference in this case may be due to prior exposure to anthracyclines either in the metastatic or adjuvant setting. For both of these comparisons there was no statistically significant heterogeneity.

Combination regimens were also associated with better time to progression and significantly improved response rates. The addition of chemotherapy agents to the same single-agent cytotoxic generally created a more intense regimen and resulted in a greater anti-tumour response, and toxicity related to alopecia and reduced white cell count.

Subgroup analyses by class did not find any advantage for single agents. When added to a regimen, taxane appeared to confer an advantage compared to its use as a single agent. The addition of anthracycline to a regimen appeared to offer a statistically significant benefit for time to progression and response over anthracycline given alone although there was no difference between them for overall survival. The sub-group analyses should however be interpreted with some caution given the smaller number of patients available in each subgroup, and the potential for confounding. For example, this review has not been able to take into consideration that some women will have been pre-treated 
(increasingly in an adjuvant setting or for metastatic disease) with a taxane or anthracycline. In addition some regimens in this review used agents which are no longer considered standard treatment and which could be regarded as suboptimal chemotherapy regimens containing mitomycin, vinblastine, and fluorouracil for example.

Increased toxicity, namely nausea and vomiting, alopecia and reduction in white cell count was consistently associated with combination regimens. This is not unexpected given the range of combinations and levels of activity. This review included trials published from the late 1970s to the present and as such reflect a wide variation in the management of side effects including dose reduction, anti-emetics and growth factor support. Rates of toxic or treatment related death were similar in both groups ( 57 deaths in the single agent arms and 53 in the combination regimen arms).

Considerable heterogeneity was evident across the various time to progression and response analyses. This is likely to reflect clinical diversity of the participants (menopausal status, hormone receptor status, disease stage and HER2 status) and interventions (the varying efficacy of the comparator regimens, the different agents, dosages and schedules) leading to an intervention effect which was different in different trials. An attempt was made to account for the clinical heterogeneity by grouping the trials according to sub-groups reflecting common treatment practices however many subgroups were then too small for meaningful analysis.

The findings in relation to quality of life offer mixed results and our observations are based on the subjective interpretation of only eleven individual trial reports. In general, survival gains with combination therapy came at the cost of a significant increase in toxicity and impact on other factors such as psychosocial morbidity, which contribute to the quality of life for this group of women. There were insufficient data in this review to comment on the overall impact of the regimens on net clinical benefit from the women's perspective. Clinical trials research increasingly includes routine assessment of quality of life indicators. These trials also need to take into account the information needs of women which support their decision-making about the potential benefits of additional treatments (small survival gains) in progressing metastatic disease and the impact this has on their quality of life.

Although this review shows a benefit for the major outcomes in favour of the combination regimen chemotherapy, there are many factors which are unaccounted for in this review, including hormone receptor status and HER2 status of the participants. This review was also not able to address the issue of whether combination regimens are more effective than single agents given sequentially. Some individual trials raised the possibility that giving a multiagent regimen sequentially with immediate cross-over from one agent to the next on progression may result in survival times similar to that seen when all the agents are given together (e.g. Sledge $G(A)$ 2003, Sledge $G(B)$ 2003). This is a question which equally should be addressed.

In addition this review has not addressed the increasing use of targeted biologics such as trastuzumab and bevacizumab, and the effect that treatment with these agents may have on the way chemotherapy is administered.

\section{AUTHORS' CONCLUSIONS}

\section{Implications for practice}

Combination-chemotherapy regimens appear to offer a benefit in overall survival, time to progression and response over traditional single chemotherapy agents that include cyclophosphamide, fluorouracil, epirubicin, lomustine and ifosamide. The findings are consistent with the review of Fossati 1998 although they are not necessarily applicable to some of the more modern single agents including, docetaxel, paclitaxel and capecitabine for example.

The main limitation in this review is that very few studies actually reported the rate of cross-over to the additional agent upon progression on mono-therapy. A further systematic review is underway which will compare combination chemotherapy to the same drugs given sequentially.

\section{Implications for research}

Additional research is needed to further explore the relationships between response, toxicity, time to progression, survival and quality of life for single and combination regimens particularly in relation to modern cyctotoxic agents and targeted therapies. All trials of chemotherapy regimens must include rigorous quality of life measures to be integrated with all treatment research in order to extract the most meaningful data for patient decision making and care.

\section{ACKN OWLEDGEMENTS}

We would like to thank Nicole Holcroft for her assistance with the identification of studies on the Cochrane Breast Cancer Group's Specialised Register. We also acknowledge the initial input by Libby Weir, Merce Marzo, Annie Cooney and the contribution made to the original concept for this review by I. Craig Henderson, Kathleen Pritchard, Martin Tattersall, Martin Stockler, Christine Brunswick, Roldano Fossati and Alessandro Liberati. We would also like to thank Stephane Heritier for providing statistical guidance. 


\section{R E F E R E N C E S}

\section{References to studies included in this review}

Ahmann DL 1974(1) \{published data only\}

* Ahmann DL, Bisel HF, Hahn RG. A phase 2 evaluation of 1 (2 chloroethyl) 3 (4 methylcyclohexyl) 1 nitrosourea (NSC 95441) in. Cancer Research 1974;34:27-30.

Ahmann DL, Schaid DJ, Bisel HF, Hahn RG, Edmonson JH, Ingle JN. The effect on survival of initial chemotherapy in advanced breast cancer: polychemotherapy. Journal Clinical Oncology 1987;5:1928-32.

Ahmann DL 1974(2) \{published data only\}

* Ahmann DL, Bisel HF, Hahn RG. Phase II clinical trial of isophosphamide (NSC-109724) in patients with advances breast cancer. Cancer Chemotherapy Reports - Part 1 1974;58(6):861-5.

Ahmann DL, Schaid DJ, Bisel HF, Hahn RG, Edmonson JH, Ingle JN. The effect on survival of initial chemotherapy in advanced breast cancer: polychemotherapy. J Clin Oncol 1987;5:1928-1932.

\section{Ahmann DL 1974(3) \{published data only\}}

* Ahmann DL, Bisel HF, Eagan RT, Edmonson JH, Hahn RG. Controlled evaluation of adriamycin (NSC-123127) in patients with disseminated breast cancer. Cancer Chemotherapy Reports 1974;58:877-82.

Ahmann DL, Schaid DJ, Bisel HF, Hahn RG, Edmonson JH, Ingle JN. The effect on survival of initial chemotherapy in advanced breast cancer: polychemotherapy. Journal of Clinical Oncology 1987;5:1928-32.

\section{Albain KS 2004 \{published data only\}}

* Albain KS, Nag S, Calderillo-Ruiz G, Jordaan JP, Llombart A, Pluzanska A, Pawlicki M, Melemed AS, O'Shaughnessy J, Teyes JM. Global Phase III study of gemcitabine plus paclitaxel versus paclitaxel as frontline therapy for metastatic breast cancer. In: Proceedings of the American Society of Clinical Oncolcogy. 2004:Abstract 510

Moinpour, C, Wu, J, Donaldson, G, Liepa, A, Melemed, A, Oshaughnessy, J, Rappold, E, Albain, K Moinpour, C, Wu, J, Donaldson, G, Liepa, A, Melemed, A, Oshaughnessy, J, Rappold, E, Albain, K. Gemcitabine plus paclitaxel (GT) versus paclitaxel $(\mathrm{T})$ as first-line treatment for anthracycline pretreated metastatic breast cancer (MBC): Quality of life (QoL) and pain palliation results from the global phase III study. In: ASCO. Vol. 22. 2004

\section{Andersson M 1986 \{published data only\}}

* Andersson M, Daugaard S, von der Maase H, Mouridsen HT. Doxorubicin versus mitomycin versus doxorubicin plus mitomycin in advanced breast cancer: a randomized study. Cancer Treat Rep 1986;70(10):1181-6.

ANZBCTG 2001 \{unpublished data only\}

* Australia and New Zealand Breast Cancer Trials Group. Phase

III randomised trial to evaluate single agent (MTZ) versus combination (CMFp) cytotoxic therapy in advanced breast cancer. Annual Scientific Report 2001.

Simes, RJ, Gebski, V, Coates, AS, Forbes, J, Harvey, V, Van Hazel, G, Tattersall, MHN, Abdi, E, Brigham, B. Quality of life (QOL) with single agent mitozantrone (MTZ) or combination chemotherapy (CMFP) for advanced breast cancer: a randomised trial. Proceedings of the American Society of Clinical Oncology 1994;13:73.

Berruti D 2002 \{published data only\}

* Berruti D 2002. Time to progression in metastatic breast cancer patients treated with epirubicin is not improved by the addition of either cisplatin or lonidamine: final results of a phase III study with a factorial design. Journal of Clinical Oncology 15-10-2002;20(20):4150-59.

Bishop J 1999 \{published data only\}

* Bishop J 1999. Initial paclitaxel improves outcome compared with CMFP combination chemotherapy as front-line therapy in untreated metastatic breast cancer. Journal of Clinical Oncology 1999;17(8):2355-64.

Bonneterre J 2002 \{published data only\}

* Bonneterre J 2002. Docetaxel vs 5-fluorouracil plus vinorelbine in metastatic breast cancer after anthracycline therapy failure. British Journal of Cancer 18-11-2002;87(11):1210-15.

Canellos GP 1976 \{published data only\}

* Canellos GP, Pocock SJ, Taylor SG, Sears ME, Klaasen DJ, Band PR. Combination chemotherapy for metastatic breast carcinoma. Prospective comparison of. Cancer 1976;38:1882-6.

Carmo-Pereira 1980 \{published data only\}

* Carmo-Pereira J, Costa FO, Henriques E. Single-drug vs combination cytotoxic chemotherapy in advanced breast cancer: a randomized. European Journal of Cancer 1980;16(12):1621-5.

\section{Eagan RT 1976 \{published data only\}}

* Eagan RT 1976. Evaluation of VP-16 and the combination of adriamycin and vincristine in advanced breast cancer. Oncology 1976;33:146-8.

\section{Ejlertsen B 2004 \{published data only\}}

* Ejlertsen B, Mouridsen HT, Langkjer ST, Andersen J, Sjostrom J, Kjaer M. Phase III study of intravenous vinorelbine in combination with epirubicin versus epirubicin alone in patients with advanced breast cancer: A Scandinavian Breast Group Trial (SBG9403). Journal of Clincal Oncology 2004;27:2313-20.

Ejlertsen B. Phase III randomised study of epirubicin/ vinorelbine vs epirubicin alone for advanced breast cancer. PDQ 1996. 
Erkisi M 1997 \{published data only\}

* Erkisi M, Bilkay BC, Seyrek E, Hazar B, Burgut R. Refractory breast cancer: a comparison of two different chemotherapy regimens. Journal Chemotherapy 1997;9:442-5.

\section{Falkson G 1990 \{published data only\}}

Falkson G, Falkson HC, Glidewell O, Weinberg V, Leone L, Holland JF. Improved remission rates and remission duration in young women with metastatic breast cancer following combined oophorectomy and chemotherapy. A study by cancer and leukemia group B. Cancer 1979;43:2215-22.

* Falkson G 1990. Survival of premenopausal women with metastatic breast cancer. Long-term follow-up of Eastern Cooperative Group and Cancer and Leukemia Group B studies. Cancer 1990;66(7):1621-9.

\section{Fraser S 1993 \{published data only\}}

Fraser SC, Ramirez AJ, Ebbs SR, Fallowfield LJ, Dobbs HJ, Richards MA, Bates T, Baum M. A daily diary for quality of life measurement in advanced breast cancer trials. British Journal of Cancer 1993;67(2):341-6.

* Fraser SC Dobbs HJ, Ebbs SR, Fallowfield LJ, Bates T, Baum M. Combination or mild single agent chemotherapy for advanced breast cancer? CMF vs. British Journal of Cancer 1993;67(2):402-6.

\section{French Epi (A) 1991 \{published data only\}}

* French Epirubicin Study Group. A prospective randomized trial comparing epirubicin monochemotherapy to two fluorouracil, cyclophosphamide, and epirubicin regimens differing in epirubicin dose in advanced breast cancer patients. The French Epirubicin Study Group [see comments]. Journal of Clinical Oncology 1991;9(2):305-12.

\section{French Epi (B) 1991 \{published data only\}}

* French Epirubicin Study Group. A prospective randomized trial comparing epirubicin monochemotherapy to two fluorouracil, cyclophosphamide, and epirubicin regimens differing in epirubicin dose in advanced breast cancer patients. The French Epirubicin Study Group [see comments]. Journal of Clinical Oncology 1991;9(2):305-12.

\section{GEICAM 2007 \{published data only\}}

* Miguel Martín, Amparo Ruiz, Monserrat Muñoz, Ana Balil, Jesús García-Mata, Lourdes Calvo, Eva Carrasco, Esther Mahillo, Antonio Casado, José Ángel García-Saenz, M José Escudero, Vicente Guillem, Carlos Jara, Nuria Ribelles, Fernando Salas, Celia Soto, Flavia Morales-Vasquez, César A Rodríguez, Encarna Adrover, José Ramón Mel. Gemcitabine plus vinorelbine versus vinorelbine monotherapy in patients with metastatic breast cancer previously treated with anthracyclines and taxanes: final results of the phase III Spanish Breast Cancer Research Group (GEICAM) trial. The Lancet 2007;8:219-225.

\section{Gundersen S 1986 \{published data only\}}

* Gundersen S, Kvinnsland S, Klepp O, Kvaloy S, Lund E, Host H. Weekly adriamycin versus VAC in advanced breast cancer. A randomized trial. European Journal of Cancer \& Clinical Oncology 1986;22(12):1431-4.

\section{Heidemann E 2002 \{published data only\}}

* Heidemann EStoeger et al. Is first-line single-agent mitoxantrone in the treatment of high-risk metastatic breast cancer patients as effective as combination chemotherapy? No difference in survival but higher quality of life were found in a multicenter randomized trial. Annals of Oncology 2002;13(11):1717-29.

\section{Heidemann E 2004 \{unpublished data only\}}

* Else Heidemann, Norbert Holländer, Gunter von Minckwitz, Rainer Souchon, Michael R Clemens, Martina Mahlke, Brigitte Eggeling, Manfred Schulze, Anton Scharl, Axel Hefti, Peter F Tauber, Martin Schumacher, Manfred Kaufmann. Mitoxantrone (M) versus Mitoxantrone plus Docetaxel (MDoc) as First-Line Therapy for Patients with High-Risk Metastatic Breast Cancer: Results of a Multicenter Randomized Trial Mitoxantrone (M) versus Mitoxantrone plus Docetaxel (MDoc) as First-Line Therapy for Patients with High-Risk Metastatic Breast Cancer: Results of a Multicenter Randomized Trial First-Line Therapy for Patients with High-Risk Metastatic Breast Cancer: Results of a Multicenter Randomized Trial. Unpublished manuscript 2004.

\section{Hoogstraten B(A)1976 \{published data only\}}

* Hoogstraten B, George SL, Samal B, Rivkin SE, Costanzi JJ, Bonnet JD, Thigpen T, Braine H. Combination chemotherapy and adriamycin in patients with advanced breast cancer. $\mathrm{A}$. Cancer 1976;38:13-20.

\section{Hoogstraten B(B)1976 \{published data only\}}

* Hoogstraten B, George SL, Samal B, Rivkin SE, Costanzi JJ, Bonnet JD, Thigpen T, Braine H. Combination chemotherapy and adriamycin in patients with advanced breast cancer. A. Cancer 1976;38:13-20.

\section{Icli F 2005 \{published data only\}}

Icli, F, Akbulut, H, Uner, A, Bulent, Y, Altinbas, M, Baltali, E, Komurcu, S, Erkisi, M, Demirkazik, A, Cay Senler, F. Paclitaxel (T) vs cisplatin + VP-16 (EP) in metastatic breast cancer patients treated with anthracyclines: A phase III randomized study, Turkish Oncology Group.. Annals of Oncology 2002;13:47.

* Icli, F Akbulut, H Uner, A Baltali, E Altinbas, M Coskun, S Komurcu, S Erkisi, M Demirkazik, A Cay Senler, F Sencan, 0 Buyukcelik, A Boruban, C Onue, H Zengin, NSak, SD. Paclitaxel (T) vs cisplatin + VP-16 (EP) in metastatic breast cancer patients treated with anthracyclinesCisplatin plus oral etoposide (EOP) combination is more effective than paclitaxel in patients with advacned breast cancer pretreated with anthracycline. British Journal of Cancer 2005;92:639.

\section{Ingle J 1985 \{published data only\}}

* Ingle JN, Pfeifle DM, Green SJ, Kvols LK, Brunk SF, Reuter NF, Krook, JE, Laurie JA, . Randomized clinical trial of doxorubicin alone or combined with mitolactol in women with. American Journal of Clinical Oncology 1985;8(4):275-82.

Ingle J 1989 \{published data only\}

* Ingle JN, Mailliard JA, Schaid DJ, Krook JE, Gerstner JB, Pfeifle DM, Marschke RF Jr, Long. Randomized trial of doxorubicin alone or combined with vincristine and mitomycin 
C in women with Metastatic Breast Cancer. American Journal of Clinical Oncology 1989;12(6):474-80.

\section{Joensuu H 1998 \{published data only\}}

* Joensuu H, Holli K, Heikkinen M, Suonio E, Aro AR, Hietanen P, Huovinen, R. Combination chemotherapy versus single-agent therapy as first- and second-line treatment in. Journal of Clinical Oncology 1998;16(12):3720-30.

\section{Mouridsen HT 1977 \{published data only\}}

* Mouridsen HT, Palshof T, Brahm M, Rahbek I. Evaluation of single-drug versus multiple-drug chemotherapy in the treatment of advanced. Cancer Treat Rep 1977;61(1):47-50.

\section{Nabholtz JM 1999 \{published data only\}}

* Nabholtz JM, Senn HJ, Bezwoda WR, Melnychuk D, Deschenes L, Douma J, Vandenberg. Prospective randomized trial of docetaxel versus mitomycin plus vinblastine in patients with. Journal of Clinical Oncology 1999;17(5):1413-1424.

\section{Nielsen D 2000 \{published data only\}}

* Nielsen D, Dombernowsky P, Larsen SK, Hansen OP, Skovsgaard T. Epirubicin or epirubicin and cisplatin as firstline therapy in advanced breast cancer. A phase III. Cancer Chemotherapy \& Pharmacology 2000;46(6):459-66.

\section{Nielson D 1990 \{published data only\}}

* Nielsen D, Dombernowsky P, Skovsgaard T, Jensen J, Andersen E, Engelholm SA, Hansen. Epirubicin or epirubicin and vindesine in advanced breast cancer. A phase III study. Annals of Oncology 1990;1(4):275-80.

\section{Norris B 2000 \{published data only\}}

* Norris B, Pritchard KI, Myles JJ, Bennett K, Marlin S, Skillings J, Findlay B, Vandenberg T, Goss P, Latrielle J, Rudinskas L, Lofters W, Trudeau M, Osaba D, Rodgers A. Phase III comparative study of vinorelbine combined with doxorubicin versus doxorubicin alone in disseminated metastic/recurrent breast cancer: National cancer institute of Canada Clinical Trials Group Study MA8. Journal of Clinical Oncology 2000;18:2385-94.

\section{O'Shaughnessy J 2001 \{published data only\}}

* O'Shaughnessy JA, Blum J, Moiseyenko V, Jones SE, Miles D, Bell D, Rosso R, Mauriac L, Osterwalder B, Burger HU, Laws S. Randomised, open-label, phase II trial of oral capecitabine vs. a reference arm of intravenous CMF (cyclophosphamide, methotrexate and 5-fluorouracil) as first-line therapy for advanced breast cancer. Annals of Oncology 2001;12:1247-54.

\section{O'Shaughnessy J 2002 \{published data only\}}

Miles D, Vukelja S, Moiseyenko V, Cervantes G, Mauriac I, Van Hazel G, Liu W, Ayoub JP, O'Shaughnesy JA. Survival benefit with capecitabine/docetaxel versus docetaxel alone: Analysis of therapy in a randomised Pahe III trial.. Clinical Breast Cancer 2004;Not stated:273-78.

* O'Shaughnessy, J, Miles, D, Vukelja, S, Moiseyenko, V, Ayoub, JP, Cervantes, G, Fumoleau, P, Jones, S, Lui, WY, Mauriac, L, Twelves, C, Van Hazel, G, Verma, S, Leonard, R. Superior survival with capecitabine plus docetaxel combination therapy in anthracycline-pretreated patients with advanced breast cancer: phase III trial results. Journal of Clinical Oncology 2002;20(12):2812-23.

Rubens RD 1975 \{published data only\}

* Rubens RD, Knight RK, Hayward JL. Chemotherapy of advanced breast cancer: a controlled randomised trial of cyclophosphamide. British Journal of Cancer 1975;32:730-36.

\section{Sjostrom J 1999 \{published data only\}}

* Sjostrom J, Blomqvist C, Mouridsen H, Pluzanska A, OttossonLonn S, Bengtsson NO, . Docetaxel compared with sequential methotrexate and 5-fluorouracil in patients with advanced. European Journal of Cancer 1999;35(8):1194-1201.

Sledge G(A) 2003 \{published data only\}

* Sledge GW, Neuberg D, Bernardo P, Ingle J, Martino S, Rowinsky EK, Wood W. Phase III trials of Doxorubicin, Paclitaxel, and the Combination of Doxorubicin and Paclitaxel as FrontLine Chemotherapy for Metastatic Breast Cancer: An Intergroup Trial (EII93). Journal of Clinical Oncology 2003;21(4):588-92.

\section{Sledge G(B) 2003 \{published data only\}}

* Sledge GW, Neuberg D, Bernardo P, Ingle J, Martino S, Rowinsky EK, Wood W. Phase III trials of Doxorubicin, Paclitaxel, and the Combination of Doxorubicin and Paclitaxel as FrontLine Chemotherapy for Metastatic Breast Cancer: An Intergroup Trial (EII93). Journal of Clinical Oncology 2003;21(4):588-92.

\section{Steiner R 1983 \{published data only\}}

* Steiner R, Stewart JF, Cantwell BM, Minton MJ, Knight RK, Rubens RD. Adriamycin alone or combined with vincristine in the treatment of advanced breast cancer. European Journal of Cancer \& Clinical Oncology 1983;19(11):1553-57.

\section{Stockler M 2006 \{published data only\}}

* Stockler MR, Sourjina T, Harvey V, Francis P, Byrne M, van Hazel G, Fitzharris B, Ackland S, Finch K, Lindsay D, KatoFoong A, Paksec L, Gebski V, Simes RJ, Coates AS, Forbes J. A randomized trial of capecitabine given intermittently versus continuously versus classical CMF as first line chemotherapy for women with advanced breast cancer unsuited to more intensive treatment. In: Proceedings of the American Society of Clinical Oncolcogy. Vol. Abstract 6066. 2006.

\section{Takayama T(A) 2000 \{published data only\}}

* Takayama T, Nomura Y. [A double-blind randomized comparative study of oral 5-fluorouracil (5-FU), cyclophosphamide. Gan to Kagaku Ryoho [Japanese Journal of Cancer \& Chemotherapy] 2000;27(1):73-80.

\section{Takayama T(B) 2000 \{published data only\}}

* Takayama T, Nomura Y. [A double-blind randomized comparative study of oral 5-fluorouracil (5-FU), cyclophosphamide. Gan to Kagaku Ryoho [Japanese Journal of Cancer \& Chemotherapy] 2000;27(1):73-80.

\section{Tashiro H 1994 \{published data only\}}

* Tashiro H, Nomura Y, Ohsaki A. A double blind comparative study of tegafur (FT) and UFT (a combination of Tegafur and. Japanese Journal of Clinical Oncology 1994;24(4):212-17. 
Thomas E 2008 \{published data only\}

* Eva S Thomas, Henry L Gomez, Rubi K Li, Hyun-Cheol Chung, Luis E Fein, Valorie F Chan, Jacek Jassem, Xavier B Pivot, Judith V Klimovsky, Fernando Hurtado de Mendoza, Binghe Xu, Mario Campone, Guillermo L Lerzo, Ronald A Peck, Pralay Mukhopadhyay, Linda T Vahdat, and Henri H Roché. Ixabepilone Plus Capecitabine for Metastatic Breast Cancer Progressing After Anthracycline and Taxane Treatment Ixabepilone Plus Capecitabine for Metastatic Breast Cancer Progressing After Anthracycline and Taxane Treatment. Journal of Clinical Oncology 2008;25(33):5210-17.

\section{Vaughn CB 1988 \{published data only\}}

* Vaughn CB, Green SJ, O'Bryan R, Reed M, Grozea PN, Fletcher WS, Green JB, Metch B, . VP-16 + adriamycin vs. adriamycin alone in advanced adenocarcinoma of the breast, phase II,. Medical \& Pediatric Oncology 1988;16(5):312-19.

\section{Venturino A(A) 2000 \{published data only\}}

* Venturino A, Comandini D, Simoni C, Merlini L, Naso C, Palumbo R, Fusco V, Porcile G, . Is salvage chemotherapy for metastatic breast cancer always effective and well tolerated? A. Breast Cancer Research \& Treatment 2000;60(3):195-200.

Venturino A (B) 2000 \{published data only\}

* Venturino A, Comandini D, Simoni C, Merlini L, Naso C, Palumbo R, Fusco V, Porcile G, . Is salvage chemotherapy for metastatic breast cancer always effective and well tolerated? A. Breast Cancer Research \& Treatment 2000;60(3):195-200.

\section{References to studies excluded from this review}

\section{Anonymous 2002 \{published data only\}}

* Anonymous. Combination versus mild single agent chemotherapy for advanced breast cancer. Trial register 2002.

\section{Doroshow 1997 \{unpublished data only\}}

* Doroshow. Phase II randomised study of paclitaxel versus paclitaxel and PSC 833 in advanced breast cancer (recurring less than 6 months since adjuvant or as second line for advanced disease). PDQ 1997.

\section{Jackisch C 1999 \{published data only\}}

* Jackisch. Single vs. tandem high-dose chemotherapy (HDC) for chemotherapy-sensitive metastatic breast cancer (MBC) interim results from an ongoing phase-III trial. In: 22nd Annual San Antonio Breast Cancer Symposium. 57 edition. Vol. 57. 1999:66.

\section{Kaufman PA 1998 \{published data only\}}

* Kaufman, PA, Harris, R, Skillings, J, Walde, D, Hong, A, Verma, $S$, Guevin, R, Joseph, J, Finizio, M. Losoxantrone + Paclitaxel versus Paclitaxel alone as first line chemotherapy for metastatic breast cancer (MBC): Final results of a Phase III randomized trial. In: Proceedings of the American Society of Clinical Oncology. 1988.

\section{Keller AM 2004 \{published data only\}}

* Keller AM, Mennel RG, Georgoulias VA, Nabholtz JM, Erazo A, Lluch A, Vogel CL et al. Randomized phase III trial of pegylated liposomal doxorubicin versus vinorelbine or mitomycin $\mathrm{C}$ plus vinblastine in women with taxane-refractory advanced breast cancer. Journal of Clincal Oncology 2004;22(19):3893-3901.

Keller AM, Mennel RG, Nabholtz JM, Georgoulias VA, Emmanuel DJ, Tendler CL. Phase III trial of pegylated liposomal doxorubicin (Caelyx/Doxil) for the treatment of patients with advanced breast cancer who have failed a prior taxane containing chemotherapy. In: American Society of Clinical Oncology. Vol. Abstract 115. 2001.

Legha, 1979 \{published data only\}

* Legha SS, Buzdar AU, Hortobagyi GN, et al. Phase II study of hexamethylmelamine alone and in combination with mitomycin C and. Cancer Treat Rep 1979;63(11-12):2053-6.

Liu T 1986 \{published data only\}

* Liu TJ. Dynamic hormonal chemotherapy in advanced metastatic breast carcinoma. Journal of the Formosan Medical Association 1986;85(4):376-83.

\section{Mann GB 1985 \{published data only\}}

* Mann GB, Hortobagyi GN, Buzdar AU, Yap HY, Valdivieso M. A comparative study of PALA, PALA plus 5-FU, and 5-FU in advanced breast cancer. Cancer 1985;56(6):1320-24.

\section{Nemoto T. 1978 \{published data only\}}

* Nemoto, T, Rosner, D, Diaz, R, Dao, T, Sponzo, R, Cunningham, T, Horton, J, Simon, R. Combination chemotherapy for metastatic breast cancer: comparison of multiple drug therapy with 5-fluorouracil, cytoxan and prednisone with adriamycin or adrenalectomy. Cancer 1978;41:2073-77.

\section{Perez E 2001 \{published data only\}}

* Perez E. Phase III randomized study of paclitaxel with or without carboplatin as first line chemotherapy in elderly women with metastatic breast cancer. Trial register 2001.

\section{References to ongoing studies}

Burzynski 1999 \{unpublished data only\}

* Burzynski. Phase II randomised study of methotrexate with or without antineoplaston A10 capsules in women with advanced breast cancer. Trial register 1999.

Butler FO 2004 \{published data only\}

* Butler FO, Weitman L. A study of docetaxel monotherapy or DOXIL/CAAELYX and docetaxel in patients with advanced breast cancer.. PDQ 2004.

\section{Heidemann E 2001 \{published data only\}}

* Heidemann. Phase III randomized study of Mitoxantrone vs cyclophosphamide methotrexate/fluorouracil (CMF) chemotherapy for good-risk metastatic breast cancer. Trial register 2001.

\section{Yunus F. 2000 \{published data only\}}

* Yunus F. Phase III randomized study of paclitaxel with or without gemcitabine in women with. Trial register 2000 


\section{Additional references}

\section{Cardoso 2002}

F Cardoso, A Di Leo, C Lohrisch, C Bernard, F Ferreira \& MJ Piccart. Second and subsequent lines of chemotherapy for metastatic breast cancer: what did we learn in the last two decades? Annals of Oncology 2002;13:197-207.

\section{Colozza 2007}

Mariantonietta Colozza, Evandro de Azambuja, Nicola Personeni, Fabienne Lebrun, Martine J Piccart, Fatima Cardoso. Achievements in systemic therapies in the pregenomic era in metastatic breast cancer. Oncologist 2007;12:253-70.

\section{Crown 2004}

John Crown, Michael O'Leary, Wei-Seong Ooi. Docetaxel and paclitaxel in the treatment of breast cancer:a review of clinical experience. The Oncologist 2004;9(suppl 2):24-32.

\section{Ferlay 2002}

J Ferlay, F Bray, P Pisani, DM Parkin. Cancer Incidence, Mortality and Prevalence Worldwide. GLOBOCAN, Version 2.0. IARC CancerBase No. 5. 2002:http://www-dep.iarc.fr/globocan/ globocan.html.

\section{Fossati 1998}

Fossati R, Confalonierir C, Torri V, Ghislandi E, Penna A, Pistotti V, Tinazzi A, Liberati A. Cytotoxic and hormonal treatment for metastatic breast cancer: a systematic review of published randomized trials involving 31,510 women. Journal of Clinical Oncology 1998;16(10):3439-3460.

\section{Hortobagyi 1996}

Hortobagyi GN, Piccart-Gebhart MJ. Current Management of Advanced Breast Cancer.. Seminars in Oncology 1996;23(Suppl 11):1-5.

\section{Hryniuk 1987}

Hryniuk WA, Figueredo A, Goodyear M. Applications of dose intensity to problems in chemotherapy of breast and colorectal cancer.. Seminare in Oncology 1987;11(Suppl 4):3-11.

\section{Martín 2007}

Miguel Martín, Amparo Ruiz, Monserrat Muñoz, Ana Balil, Jesús García-Mata, Lourdes Calvo, Eva Carrasco, Esther Mahillo, Antonio Casado, José Ángel García-Saenz, M José Escudero, Vicente Guillem, Carlos Jara, Nuria Ribelles, Fernando Salas, Celia Soto, Flavia Morales-Vasquez, César A Rodríguez, Encarna Adrover, José Ramón Mel. Gemcitabine plus vinorelbine versus vinorelbine monotherapy in patients with metastatic breast cancer previously treated with anthracyclines and taxanes: final results of the phase III Spanish Breast Cancer Research Group (GEICAM) trial. The Lancet 2007;8:219-225.

\section{Nabholtz 2002}

Jean-Marc Nabholtz, David Reese, Mary-Anne Lindsay. Evidence for the use of chemotherapy in breast cancer. International Journal of Clinical Oncology 2002;7:254-64.

\section{NBCC 2007}

National Breast Cancer Centre. Recommendations for use of Trastuzumab (Herceptin ${ }^{\circledR}$ ) for the treatment of HER2-positive breast cancer. http://www.nbcc.org.au/resources/resource.php? code=HERG 2007.

\section{O'Shaughnessy 2002}

Joyce O'Shaughnessy, Chris Twelves, Matti Aapro. Treatment for anthracycline-pretreated metastatic breast cancer. Oncologist 2002;7:4-12.

\section{O'Shaughnessy 2005}

Joyce O'Shaughnessy. Extending survival with chemotherapy in metastatic breast cancer. Oncologist 2005;10:20-9.

\section{Overmoyer 2003}

Beth Overmoyer. Combination chemotherapy for metastatic breast cancer: reaching for the cure. Journal of Clinical Oncology 2003;21(4):580-2.

\section{Parmar 1998}

Parmar MKB, Torri V, Stewart L. Extracting summary statistics to perform meta-analyses of the published literature for survival endpoints. Statistics in Medicine 1998;17:2815-2834.

\section{Seidman 2003}

Andrew D Seidman. Sequential single-agent chemotherapy for metastatic breast cancer: therapeutic nihilism or realism. Journal of Clinical Oncology 2003;21(4):577-9.

\section{Smith 2006}

Smith I. Goals of treatment for patients with metastatic breast cancer. Seminars in Oncology 2006;32(S2):S2-5.

\section{Stockler 2000}

Stockler M, Wilcken NRC, Ghersi D, Simes RJ. Systematic reviews of chemotherapy and endocrine therapy in metastatic breast cancer.. Cancer Treatment Reviews 2000;26:151-168.

\section{Tierney 2007}

Jayne F Tierney, Lesley A Stewart, Davina Ghersi, Sarah Burdett, Matthew R Sydes. Practical methods for incorporating summary time-to-event data into meta-analysis. Trials 2007;8(16):http:// www.trialsjournal.com/content/8/1/16.

\section{Wilcken 2003}

Wilcken N, Hornbuckle J, Ghersi D. Chemotherapy alone versus endocrine therapy alone for metastatic breast cancer.. Cochrane Database of Systematic Reviews 2003, Issue 2.. Art. No: CD002747. [DOI: 10.1002/14651858.CD002747]

\section{Yusuf 1985}

Yusuf S, Peto R, Lewis J, Collins R, Sleight P. Beta blockade during and after myocardial infarction: an overview of the randomized trials. Progress in Carciovascular Diseases 1985;27:335-371. 


\section{References to other published versions of this review}

\section{Carrick 2005}

Carrick S, Parker S, Wilcken N, Ghersi D, Marzo M, Simes J. Single agent versus combination chemotherapy for metastatic breast cancer. Cochrane Database of

\section{CHARACTERISTICS OF STUDIES}

Characteristics of included studies [ordered by study ID]

Ahmann DL 1974(1)

\section{Study characteristics}

$\begin{array}{ll}\text { Methods } & \text { RCT - consecutive candidates for cytotoxic treatment at the clinic } \\ \text { Baseline comparability }\end{array}$
Baseline comparability

Participants women with MBC confirmed histopathologically and suitable for serial measurement
$100 \%$ MBC
$100 \%$ Firstline
Postmenopausal
Randomised and assessable no:
1) $n=22$
2) $n=21$

Interventions

CCNU (Lomustine) vs $\mathrm{F}+\mathrm{C}+\mathrm{P}+/-\mathrm{V} 1$

1) Methyl CCNU $225 \mathrm{mg} / \mathrm{sq}$ MPO day 1

2) 5 Fluorouracil $8 \mathrm{mg}$ daily IV for 5 days +

Cyclophosphamide $4 \mathrm{mg}$ daily IV for 5 days +

Prednisone PO $30 \mathrm{mg}$ 2/52, 20mg 3rd week, $10 \mathrm{mg}$ thereafter

plus or minus Vincristine $1.4 \mathrm{mg} / \mathrm{m} 2$ IV day 1 and 5 (11 patients from group 2)

Survival curve - ascertained from associated paper - Kaplan-Meier estimate
Median survival
1) $11.7 \mathrm{mths}(9.1-15.5 \mathrm{mths})$
2) $18.6 \mathrm{mths}(9.3-25.1 \mathrm{mths})$
Response
1) $1 / 22$
2) $12 / 21$
Toxicity data - NE
One death (adriamycin arm) - post mortum did not find attributable to treatment.
F/U - min $1.8 \mathrm{mths}$ (rounded up to 2 mths (based on 2 cycles) - max $120 \mathrm{mths}$ (estimated from curve)
First of three trials - with a combined total of 131 patients. Crossover at progression of disease - $11 / 21$
to Vincristine from group 2
All patients included in the analysis for all three trials - all but one patient observed till death (still alive
at time of report)
Pooled data from all 3 trials also analysed - single versus combination therapy but not used in this re-
view

Risk of bias

\section{Authors' judgement Support for judgement}


Ahmann DL 1974(1) (Continued)

Random sequence genera- High risk Publication states Patients were consecutive candidates for cytotoxic treattion (selection bias) ment at the clinic. It is unclear if this means consecutively sampled or consecuetively allocated

\begin{tabular}{lll}
\hline $\begin{array}{l}\text { Allocation concealment } \\
\text { (selection bias) }\end{array}$ & Unclear risk & Not reported \\
\hline $\begin{array}{l}\text { Incomplete outcome data } \\
\text { (attrition bias) }\end{array}$ & Low risk & No missing outcome data \\
All outcomes & & \\
\hline
\end{tabular}

Selective reporting (re- Unclear risk Insufficient information to fully assess
porting bias)

Selective reporting (re- $\quad$ Unclear risk $\quad$ Insufficient information to fully assess
porting bias)

Ahmann DL 1974(2)

\section{Study characteristics}

\begin{tabular}{|c|c|}
\hline Methods & $\begin{array}{l}\text { Accrual (May 1972- December 1972) } \\
\text { RCT - consecutive candidates for cytotoxic treatment at the clinic }\end{array}$ \\
\hline Participants & $\begin{array}{l}40 \text { women with measurable disease, metastatic, locally inoperable or recurrent breast cancer } \\
100 \% \text { MBC } \\
100 \% \text { Firstline } \\
\text { Randomised and assessable no: } \\
\text { 1) } n=20 \\
\text { 2) } n=20\end{array}$ \\
\hline Interventions & $\begin{array}{l}\text { I vs } \mathrm{F}+\mathrm{C}+\mathrm{P}+/-\mathrm{V} 1 \\
\text { 1) Iphosphamide } 4 \mathrm{mg} / \mathrm{m} 2 \mathrm{IV} \text { day } 1 \text { (analogue of cyclophosphamide) } \\
\text { 2) } 5 \text { Fluorouracil } 8 \mathrm{mg} \text { daily IV for } 5 \text { days }+ \\
\text { Cyclophosphamide } 4 \mathrm{mg} \text { daily IV for } 5 \text { days }+ \\
\text { Prednisone PO } 30 \mathrm{mg} 2 / 52,20 \mathrm{mg} 3 \mathrm{rd} \text { week, } 10 \mathrm{mg} \text { thereafter } \\
\text { plus or minus Vincristine } 1.4 \mathrm{mg} / \mathrm{m} 2 \text { IV day } 1 \text { and } 5 \text { (9 patients from group 2) }\end{array}$ \\
\hline Outcomes & $\begin{array}{l}\text { Survival curve - ascertained from associated paper - Kaplan-Meier estimate } \\
\text { Median survival } \\
\text { 1) } 17.6 \text { mths ( } 8.1-22.5 \text { mths) } \\
\text { 2) } 13.3 \text { mths ( } 9.7 \text { - } 18.3 \text { mths) } \\
\text { Response and toxicity data cannot be extracted }\end{array}$ \\
\hline Notes & $\begin{array}{l}\text { F/U - min } 1.8 \mathrm{mths} \text { (rounded up to } 2 \mathrm{mths} \text { (based on } 2 \text { cycles) - max } 98 \mathrm{mths} \text { (estimated from curve) } \\
\text { Second of three trials - with a combined total of } 131 \text { patients. Crossover at progression of disease - } \\
11 / 21 \text { to Vincristine from group } 2 \\
\text { All patients included in the analysis for all three trials - all but one patient observed till death (still alive } \\
\text { at time of report) }\end{array}$ \\
\hline & $\begin{array}{l}\text { Pooled data from all } 3 \text { trials also analysed - single versus combination therapy but not used in this re- } \\
\text { view }\end{array}$ \\
\hline
\end{tabular}

\section{Risk of bias}


Ahmann DL 1974(2) (Continued)

Random sequence genera- High risk Publication states Patients were consecutive candidates for cytotoxic treattion (selection bias) ment at the clinic. It is unclear if this means consecutively sampled or consecuetively allocated

\begin{tabular}{lll}
\hline $\begin{array}{l}\text { Allocation concealment } \\
\text { (selection bias) }\end{array}$ & Unclear risk & Not reported \\
\hline $\begin{array}{l}\text { Incomplete outcome data } \\
\text { (attrition bias) }\end{array}$ & Low risk & No missing outcome data \\
All outcomes & & \\
\hline
\end{tabular}

Selective reporting (re- Unclear risk Insufficient information to fully assess
porting bias)

Selective reporting (re- Unclear risk $\quad$ Insufficient information to fully assess
porting bias)

Ahmann DL 1974(3)

\section{Study characteristics}

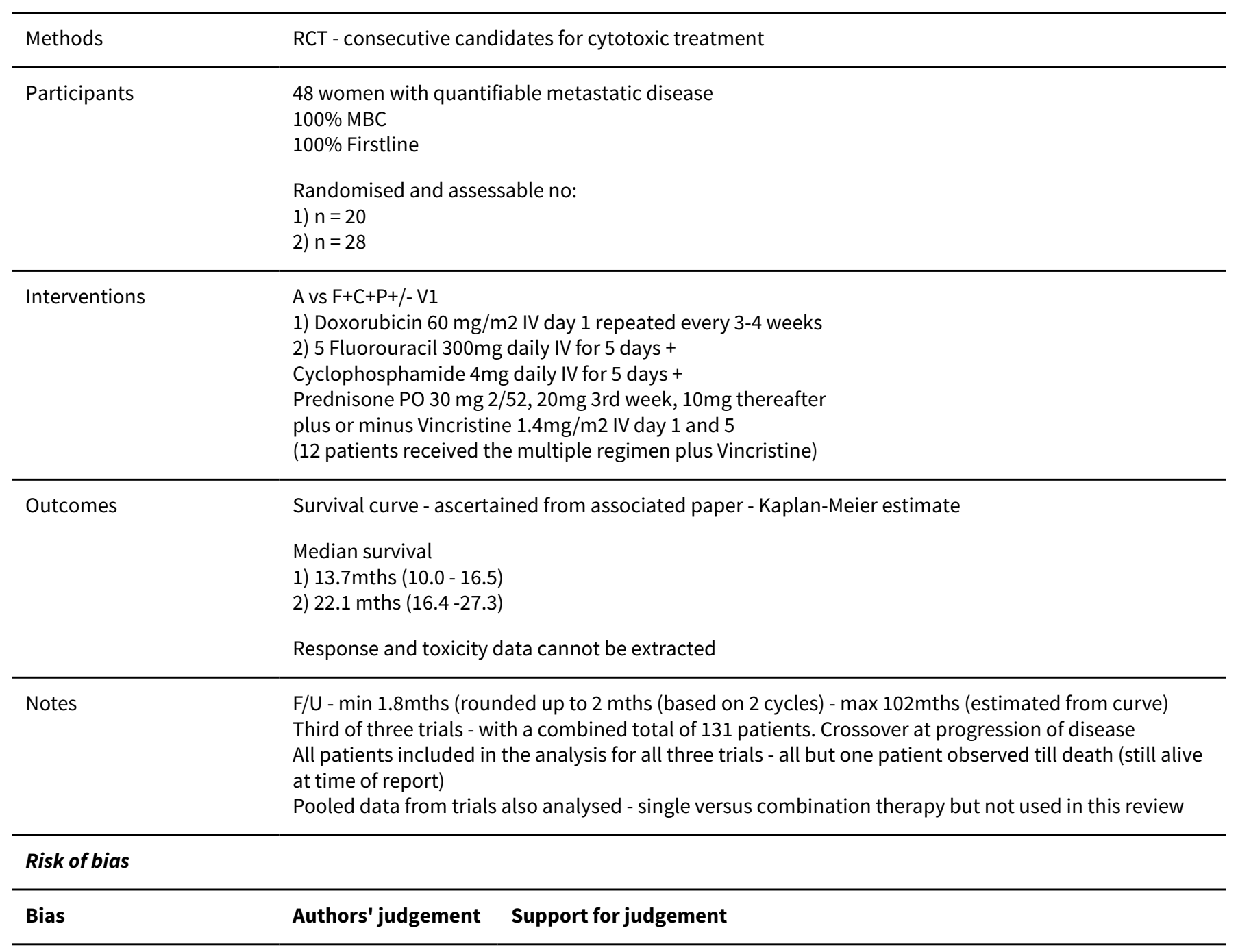


Ahmann DL 1974(3) (Continued)

Random sequence genera- High risk Publication states Patients were consecutive candidates for cytotoxic treattion (selection bias) ment at the clinic. It is unclear if this means consecutively sampled or consecuetively allocated

Allocation concealment Unclear risk Not reported

(selection bias)

Incomplete outcome data Low risk No missing outcome data
(attrition bias)

(attrition bias)

All outcomes

Selective reporting (re- Unclear risk Insufficient information to fully assess porting bias)

\section{Albain KS 2004}

\section{Study characteristics}

Methods $\quad$ Accrual - (August 1999 - April 2002).

RCT - centrally randomised patients, multi-centred international. Phase III.

Baseline Comparability

\begin{tabular}{ll}
\hline Participants & 529 women with unresectable, locally recurrent or metastatic lesions \\
At least $96.9 \% \mathrm{MBC}$ \\
$100 \%$ Firstline \\
Randomised no: \\
1) $\mathrm{n}=262$ \\
2) $\mathrm{n}=267$ \\
Assessable no: \\
1) $\mathrm{n}=259$ \\
2) $\mathrm{n}=262$ \\
PACL vs PACL $+\mathrm{Gem}$ \\
1) Paclitaxel $175 \mathrm{mg} / \mathrm{m} 2$ (3hr) \\
every $3 / 52$ \\
2) Paclitaxel $175 \mathrm{mg} / \mathrm{m} 2$ (3hr) day $1+$ \\
Gemcitabine $1250 \mathrm{mg} / \mathrm{m} 2$ day 1 then \\
Gemcitabine $1250 \mathrm{mg} / \mathrm{m} 2$ day 8
\end{tabular}

Outcomes

Overall survival and TTP curves - measured from 3 weeks following randomisation till death. Kaplan-Meier curves.

Median survival

1) 15.8 mths $(14.4,17.4)$

2) $18.5 \mathrm{mths}(16.5,21.2)$

Median TTP

1) 2.9 months

2) 5.2 months

OR (CR and PR)

1) $57 / 259$

2) $107 / 262$

Toxicity (3-4) 
Albain KS 2004 (Continued)

Nausea and vomiting

1) $2 / 259$

2) $2 / 262$

Neutropenia

1) $11 / 259$

2) $48 / 262$

Toxic death

1) $1 / 259$

2) $1 / 262$

Notes

F/U survival min $1 \mathrm{mth}$ - $12 \mathrm{mths}$ (based on curve)

F/U TTP min 1mth - 37mths (based on curve)

\section{Risk of bias}

\begin{tabular}{|c|c|c|}
\hline Bias & Authors' judgement & Support for judgement \\
\hline $\begin{array}{l}\text { Random sequence genera- } \\
\text { tion (selection bias) }\end{array}$ & Unclear risk & Just states 'randomised' \\
\hline $\begin{array}{l}\text { Allocation concealment } \\
\text { (selection bias) }\end{array}$ & Unclear risk & Not reported \\
\hline $\begin{array}{l}\text { Incomplete outcome data } \\
\text { (attrition bias) } \\
\text { All outcomes }\end{array}$ & Unclear risk & Cannot assess as this is a conference abstract \\
\hline $\begin{array}{l}\text { Selective reporting (re- } \\
\text { porting bias) }\end{array}$ & Unclear risk & Insufficient information \\
\hline
\end{tabular}

\section{Andersson M 1986}

\section{Study characteristics}

Methods $\quad$ Accrual - (Jan 1981- August 1984)

RCT - centrally registered and allocated randomly in a non stratified way

Groups comparable in all ways except number of organ sites which was higher in the combination arm

Participants
$\begin{aligned} & \text { At least } 63 \% \mathrm{MBC} \text { (\% dominant site - bone and viscera) } \\ & 22.5 \% \text { Firstline } \\ & 77.5 \% \text { Secondline } \\ & \text { Randomised no: } \\ & \text { 1) } n=45 \\ & \text { 2) } n=44 \\ & \text { Assessable no: (following discontinuation of Mitomycin arm) } \\ & \text { 1) } n=42 \text { (median age } 59 ; 46-67) \\ & \text { 2) } n=39 \text { (median age } 61 ; 44-70) \\ & \text { A vs A+ MMC } \\ & \text { Interventions Doxorubicin } 75 \mathrm{mg} / \mathrm{m} 2 \text { IV every } 3 / 52\end{aligned}$


Andersson M 1986 (Continued)

2) Doxorubicin $45 \mathrm{mg} / \mathrm{m} 2$ IV every $3 / 52+$

Mitomycin $10 \mathrm{mg} / \mathrm{m} 2$ IV every $6 / 52$

Survival and TTP curves - Kaplan-Meier estimates
Median TTP
1) 5.2 mths $(4.7-6.5)$
2) 7.7 mths $(5.4-10.1)$
Response (CR and PR)
1) $20 / 42$
2) $19 / 39$
Toxicity WHO 3-4
Nausea and vomiting
1) $8 / 42$
2) $20 / 39$
Toxic death - 4 patients in combination arm - thrombopenia (2); cardiomyopathy (2)
F/U survival min 2 mths - max 31 mths (estimated from curve)
F/U min 2 mths - max. 17 mths (estimated from curve)
101 patients initially randomised to a arm of single mitomycin but this was discontinued (12 patients)
due to severe toxicity. These patients are not included in the analysis
Two patients in each group were not evaluable for response due to treatment refusal - these were in-
cluded in the analysis for TTP, survival and toxicity. There was no loss to follow up

\section{Risk of bias}

\begin{tabular}{lll}
\hline Bias & Authors' judgement & Support for judgement \\
\hline $\begin{array}{l}\text { Random sequence genera- } \\
\text { tion (selection bias) }\end{array}$ & Unclear risk & States "centrally registered and allocated randomly in a non stratified way" \\
\hline $\begin{array}{l}\text { Allocation concealment } \\
\text { (selection bias) }\end{array}$ & Low risk & Centrally randomised \\
\hline $\begin{array}{l}\text { Incomplete outcome data } \\
\text { (attrition bias) } \\
\text { All outcomes }\end{array}$ & Low risk & $\begin{array}{l}\text { Two patients in each group were not evaluable for response due to treatment } \\
\text { refusal - these were included in the analysis for TTP, survival and toxicity. }\end{array}$ \\
\hline $\begin{array}{l}\text { Selective reporting (re- } \\
\text { porting bias) }\end{array}$ & Low risk & Protocol not available but but all expected outcomes reported \\
\hline
\end{tabular}

ANZBCTG 2001

\section{Study characteristics}

\begin{tabular}{ll}
\hline Methods & Accrual (January 1988 - June 1993) \\
& RCT - randomisation method not described \\
Stratification based on performance status, site of metastases and institution \\
Multi-centre - Australian and New Zealand \\
\hline Participants & 391 women with advanced breast cancer \\
& $100 \%$ MBC \\
\hline
\end{tabular}


ANZBCTG 2001 (Continued)
$100 \%$ Firstline
Randomised no:
1) $n=197$
2) $n=194$
Assessable no:
1) $n=192$
2) $n=190$

Interventions
MZA vs CMFP
1)Mitozantrone $14 \mathrm{mg} / \mathrm{m} 2$ day 1
2)CMFP
cyclophosphamide $100 \mathrm{mg} / \mathrm{m} 2$ po days $1-4$
methotrexate $40 \mathrm{mg} / \mathrm{m} 2 /$ iv days 1 and 8
5 Fluorouracil $600 \mathrm{mg} / \mathrm{m} 2$ IV days 1 and 8
Prednisone $40 \mathrm{mg} / \mathrm{m} 2$ po days 1 -14
Patients crossed over to the alternative treatment at progression

\begin{tabular}{ll}
\hline Outcomes & OS or TTP curves are not \\
TTF curve excluded & \\
& OR (CR +PR) \\
1) $47 / 197$ \\
2) $70 / 194$ \\
Toxicity WHO 3-4 \\
Nausea and vomiting \\
1) $62 / 192$ \\
2) $53 / 190$ \\
Alopecia \\
1) $83 / 197$ \\
2) $131 / 194$ \\
WCC \\
1) $56 / 197$ \\
2) $60 / 194$ \\
QOL - Spitzer QL index
\end{tabular}

Notes Updated data provided by trialist 2003 -

Only data from the first line comparison is included in this review

\section{Risk of bias}

\begin{tabular}{lll}
\hline Bias & Authors' judgement & Support for judgement \\
\hline $\begin{array}{l}\text { Random sequence genera- } \\
\text { tion (selection bias) }\end{array}$ & Unclear risk & Not reported \\
\hline $\begin{array}{l}\text { Allocation concealment } \\
\text { (selection bias) }\end{array}$ & Unclear risk & Not reported \\
\hline $\begin{array}{l}\text { Incomplete outcome data } \\
\text { (attrition bias) } \\
\text { All outcomes }\end{array}$ & Low risk & No missing outcome data \\
\hline $\begin{array}{l}\text { Selective reporting (re- } \\
\text { porting bias) }\end{array}$ & Low risk & Protocol available - all pre-specified outcomes reported \\
\hline \hline
\end{tabular}


Berruti D 2002

\section{Study characteristics}

\begin{tabular}{|c|c|}
\hline Methods & $\begin{array}{l}\text { Accrual (October } 1995 \text { - March 2001) } \\
\text { RCT - Multicentre Randomisation not described (stratification by investigator site done prior to ran- } \\
\text { domisation) } \\
\text { Major clinical characteristics well balanced across the } 2 \text { arms }\end{array}$ \\
\hline Participants & $\begin{array}{l}185 \text { women with measurable or assessable (WHO criteria) and histologically proven MBC } \\
100 \% \text { MBC } \\
100 \% \text { Firstline } \\
\text { Randomised no: } \\
\text { 1) } n=93 \text { (median age }=59 ; 28-75) \\
\text { 2) } n=92 \text { (median age } 57 ; 33-75)\end{array}$ \\
\hline Interventions & $\begin{array}{l}\text { E vs } E+C D D P \\
\text { 1) } E P I \text { only }=60 \mathrm{mg} / \mathrm{m} 2 \text { slow IV push on days } 1 \text { and } 2 \\
\text { 2) } E P I+C D D P=E P I 60 \mathrm{mg} / \mathrm{m} 2 \text { slow IV push on days } 1 \text { and } 2+C D D P 30 \mathrm{mg} / \mathrm{m} 2 \times 1 \mathrm{hr} \text { IV infusion on days } 1 \\
\text { and } 2 \\
C D D P \text { and EPI infusions were repeated every } 21 \text { days } \\
\text { A median of } 6 \text { cycles (1-8) was given }\end{array}$ \\
\hline
\end{tabular}

Outcomes
Survival - Not reported
PFS curve poor quality.
OR (CR+PR)
1) $47 / 93$
2) $53 / 92$
Toxicity: WHO 3-4
Nausea and vomiting
1) $17 / 91$
2) $24 / 90$
Leukopenia
1) $2 / 91$
2) $4 / 90$
Toxic death
1) 3
2) 3

Notes

F/U TTP - min 4.5mths - max 64mths (estimated from no of cycles and curve) Patients randomised into 4 arms ${ }^{\star \star \star *}$ Only EPI and CDDP arms of this study included ITT - stated in text

\section{Risk of bias}

\begin{tabular}{lll}
\hline Bias & Authors' judgement & Support for judgement \\
\hline $\begin{array}{l}\text { Random sequence genera- } \\
\text { tion (selection bias) }\end{array}$ & Unclear risk & Not reported \\
\hline $\begin{array}{l}\text { Allocation concealment } \\
\text { (selection bias) }\end{array}$ & Unclear risk & Not reported \\
\hline
\end{tabular}


Berruti D 2002 (Continued)

Incomplete outcome data Low risk No missing outcome data
(attrition bias)

All outcomes

Selective reporting (re- Low risk $\quad$ All expected outcomes reported
porting bias)

\section{Bishop J 1999}

\section{Study characteristics}

Methods Accrual (Sept $1993-1997)$

RCT - 17 centres - Aust and NZ -

Randomisation done by computer generated randomisation charts - stratified by institution

Participants 209 women with histologically proven metastatic or locally advanced breast cancer
$100 \%$ MBC
$100 \%$ Firstline
Randomised no:
1) $n=107$
(median age 54; range 36-73) - 2 did not receive treatment)
2) $n=102$ (median age 54; range $32-80$ - 3 did not receive treatment)

Interventions

PACL vs CMFP

1) Paclitaxel $200 \mathrm{mg} / \mathrm{m} 2$ IV over $3 \mathrm{hrs}$ for 8 cycles - 24 weeks

2) $\mathrm{CMFP}=$ Cyclophosphamide $100 \mathrm{mg} / \mathrm{m} 2$ oral on days $1-14$

+ Methotrexate $40 \mathrm{mg} / \mathrm{m} 2 \mathrm{IV}$ on days 1 and 8

+ Flurouracil $600 \mathrm{mg} / \mathrm{m} 2 \mathrm{IV}$ on days 1 and 8

+ Prednisone $40 \mathrm{mg} / \mathrm{m} 2$ orally on days $1-14$

for 6 cycles with EPI as 2nd line therapy

Outcomes

Survival and PFS curves - Kaplan-Meier product limit method. OS and PFS measured from the date of randomisation and the close out date for all survival analysis was Feb 20, 1997

Median survival

1) $17.3 \mathrm{mths}$

2) $13.9 \mathrm{mths}$

Median TTP

1) $5.3 \mathrm{mths}$

2) $6.4 \mathrm{mths}$

$\mathrm{OR}(\mathrm{CR}+\mathrm{PR})$

1) $31 / 107$

2) $36 / 102$

Toxicity (3-4)

Leukopenia

1) $29 / 107$

2) $66 / 102$

Nausea and vomiting

1) $1 / 107$

2) $8 / 102$

Alopecia

1) $81 / 107$ 
Bishop J 1999 (Continued)

\section{2) $24 / 102$}

Toxic death- NR

QOL- instrument linear analog scale- Spitzer for physicians

Fotes
All major end points done by Intention to treat analysis
$30 \%(1)$ and $20 \%$ (2) still alive at close out - Feb 201997
43 and 39 received 2nd line

\section{Risk of bias}

\begin{tabular}{lll}
\hline Bias & Authors' judgement & Support for judgement \\
\hline $\begin{array}{l}\text { Random sequence genera- } \\
\text { tion (selection bias) }\end{array}$ & Low risk & Randomisation done by computer generated randomisation charts \\
\hline $\begin{array}{l}\text { Allocation concealment } \\
\text { (selection bias) }\end{array}$ & Low risk & Centrally randomised \\
\hline $\begin{array}{l}\text { Incomplete outcome data } \\
\text { (attrition bias) } \\
\text { All outcomes }\end{array}$ & Low risk & No missing outcome data \\
\hline $\begin{array}{l}\text { Selective reporting (re- } \\
\text { porting bias) }\end{array}$ & Low risk & All expected outcomes reported \\
\hline
\end{tabular}

Bonneterre J 2002

\section{Study characteristics}

\begin{tabular}{ll}
\hline Methods & Accrual (June 1995 - July 1997) \\
RCT - Multi centre (22) Phase lll study - randomisation one to one basis, stratified by accruing centre \\
Baseline characteristics well balanced between study groups
\end{tabular}

Participants
Previously treated with Anthracycline based chemotherapy
$34 \%$ first line
Randomised No
1) $n=88$
2) $n=90$
Assessable no:
(176) 2 in arm 1 did not receive treatment leaving:
1) $n=86$ (median age $54.9 ; 27.9-79)$
2) $n=90$ (median age $54.55 ; 31.6-74.5$ )

\begin{tabular}{ll}
\hline Interventions & TXT vs F+V3 \\
1) Docetaxel $(100 \mathrm{mg} / \mathrm{m}-2$ every three weeks) \\
2) 5 -fluorouracil $(750 \mathrm{mg} / \mathrm{m}-2$ per day continuous infusion)+ vinorelbine $25 \mathrm{mg} / \mathrm{m}-2$ over a $30 \mathrm{minute}$ in- \\
fusion on days 1 and 5 of the 3 week cycle
\end{tabular}

Outcomes Survival and TTP curves - Kaplan-Meier - calculated from first treatment infusion

Median survival 
Bonneterre J 2002 (Continued)
1) $16 \mathrm{mths}$
2) $15 \mathrm{mths}$
Median TTP
1) $6.5 \mathrm{mths}$
2) $5.1 \mathrm{mths}$

OR (CR+PR) assessed every 3 cycles and fully assessed 28 days after final infusion

1) $37 / 86$

2) $35 / 90-$

Toxicity (WHO3/4)

Neutropenia

1) $65 / 86$

2) $60 / 90$

Nausea and vomiting

1) $4 / 86$

2) $5 / 90$

Alopecia

1) $38 / 86$

$207 / 90$

Toxic Deaths

1) 1 (CCF)

2) 5 (3 sepsis/1 liver failure/ 1 liver and renal failure).

176 patients treated - Results ITT where possible

Median follow up - 30.3 mths (10.4-45.0 mths) reported by the authors

\section{Risk of bias}

\begin{tabular}{lll}
\hline Bias & Authors' judgement & Support for judgement \\
\hline $\begin{array}{l}\text { Random sequence genera- } \\
\text { tion (selection bias) }\end{array}$ & Unclear risk & Publication states "randomisation one to one basis" \\
\hline $\begin{array}{l}\text { Allocation concealment } \\
\text { (selection bias) }\end{array}$ & Unclear risk & Not reported \\
\hline $\begin{array}{l}\text { Incomplete outcome data } \\
\begin{array}{l}\text { (attrition bias) } \\
\text { All outcomes }\end{array}\end{array}$ & Low risk & No missing outcome data \\
\hline $\begin{array}{l}\text { Selective reporting (re- } \\
\text { porting bias) }\end{array}$ & Low risk & All expected outcomes reported \\
\hline
\end{tabular}

Canellos GP 1976

\section{Study characteristics}

\section{Methods}

RCT, multi-centre -

Randomisation not described

Stratified according to prior hormonal therapy and menopausal status 
Canellos GP 1976 (Continued)

Groups well balanced

\begin{tabular}{|c|c|}
\hline Participants & $\begin{array}{l}184 \text { women with histologically confirmed MBC, previously untreated by cytotoxic chemotherapy } \\
100 \% \text { MBC } \\
100 \% \text { Firstline } \\
\text { Randomised no: } \\
\text { 1) } n=91 \\
\text { 2) } n=93\end{array}$ \\
\hline Interventions & $\begin{array}{l}\text { L-PAM (melphalan) vs CMF } \\
\text { 1) L-phenylalanine mustard } 6 \mathrm{mg} / \mathrm{m} 2 \text { (po) for } 5 \text { days every } 6 \text { wks } \\
\text { 2) } 5 \text {-Flurouracil } 600 \mathrm{mg} / \mathrm{m} 2 \text { iv days } 1 \& 8 \\
+ \text { Cyclophosphamide } 100 \mathrm{mg} / \mathrm{m} 2 \text { po daily x } 14 \text { days } \\
+ \text { Methotrexate } 60 \mathrm{mg} / \mathrm{m} 2 \text { iv days } 1 \& 8 \\
\text { CMF was a } 14 \text { day course of treatment every } 28 \text { days. }\end{array}$ \\
\hline Outcomes & $\begin{array}{l}\text { Survival curve - Kaplan-Meier } \\
\text { No TTP curves } \\
\text { Median survival } \\
\text { 1) } 9 \text { mths } \\
\text { 2) } 12 \text { mths } \\
\text { OR (CR+PR) } \\
\text { 1) } 18 / 91 \\
\text { 2) } 49 / 93 \\
\text { Toxicity } \\
\text { Nadir WBC, }<2000 / \mathrm{mm} 3 \\
\text { 1) } 7 / 91 \\
\text { 2) } 37 / 93 \\
\text { Toxic death - NR }\end{array}$ \\
\hline Notes & $\begin{array}{l}\mathrm{F} / \mathrm{U} \text { - (min } 3 \mathrm{mths} \text { based on number of cycles - max } 18 \mathrm{mths} \text { estimated from curve) } \\
\text { Duration of response statistically significant } \\
\text { All patients evaluated (ITT) }\end{array}$ \\
\hline
\end{tabular}

\section{Risk of bias}

Bias Authors' judgement Support for judgement

Random sequence genera-
tion (selection bias)

tion (selection bias)

\begin{tabular}{ll}
\hline $\begin{array}{l}\text { Allocation concealment } \\
\text { (selection bias) }\end{array}$ & Unclear risk
\end{tabular}

Incomplete outcome data Low risk No missing outcome data
(attrition bias)
All outcomes

Selective reporting (re- Low risk All expected outcomes reported
porting bias)




\section{Study characteristics}

\begin{tabular}{|c|c|}
\hline Methods & $\begin{array}{l}\text { RCT single-centre Portugal } \\
\text { Randomisation not described - Stratified according to menopausal state, disease free interval and pre- } \\
\text { dominant lesion } \\
\text { Baseline comparability }\end{array}$ \\
\hline Participants & $\begin{array}{l}135 \text { patients with metastatic } B C \text { in progression and refractory to endocrine therapy and irradiation - } \\
\text { histologically proven metastatic and measurable disease } \\
100 \% \mathrm{MBC} \\
100 \% \text { firstline }\end{array}$ \\
\hline & $\begin{array}{l}\text { Randomised no: } \\
\text { 1) } n=67 \text { (median age } 47.5) \\
\text { 2) } n=68 \text { (median age } 50)\end{array}$ \\
\hline Interventions & $\begin{array}{l}\text { F vs CMFVP } \\
\text { 1) } 5 \text { FU } 500 \mathrm{mg} / \mathrm{m} 2 \text { IV days } 1-5 \text {, then } 500 \mathrm{mg} / \mathrm{m} 2 \text { weekly } \\
\text { 2) Combination of } 5 \text { drugs CMFVP protocol ( } 5-\mathrm{FU} 300 \mathrm{mg} / \mathrm{m} 2 \mathrm{IV} \text {, MXT } 15 \mathrm{~m} / \mathrm{g} 2 \text {, IV, VCR } 0.65 \mathrm{mg} / \mathrm{m} 2 \mathrm{IV} \\
\text { weekly for } 2 \text { weeks) + (CPP } 75 \mathrm{mg} / \mathrm{m} \text { p.o daily for } 2 \text { weeks alternating with a } 2 \text { week rest period and PNS } \\
20 \mathrm{mg} / \mathrm{m} 2 \text { po daily with diminishing dose) followed by a maintenance dose used for } 3 \text { weeks off treat- } \\
\text { ment }\end{array}$ \\
\hline
\end{tabular}

Survival curve - life table method estimated from the commencement of treatment
Median survival
1) 5 mths
2) 16 mths
OR (CR+PR)
1) $12 / 67$
2) $47 / 68$
Toxicity (WHO 3-4)
Nausea and vomiting
1) $67 / 67$
2) $30 / 68$
Alopecia
1) $0 / 67$
2) $59 / 68$
Leukopenia
1) $0 / 67$
20 $7 / 68$
Toxic death - NR

\section{Risk of bias}

Bias Authors' judgement Support for judgement

Random sequence genera- Unclear risk Not reported tion (selection bias) 
Carmo-Pereira 1980 (Continued)

\begin{tabular}{lll}
$\begin{array}{l}\text { Allocation concealment } \\
\text { (selection bias) }\end{array}$ & Unclear risk & Not reported \\
\hline $\begin{array}{l}\text { Incomplete outcome data } \\
\text { (attrition bias) }\end{array}$ & Low risk & No missing outcome data \\
All outcomes & &
\end{tabular}

Selective reporting (re- Low risk All expected outcomes reported
porting bias)

\section{Eagan RT 1976}

\section{Study characteristics}

\begin{tabular}{ll}
\hline Methods & RCT \\
& Randomisation not described - stratified by site \\
& Groups fairly comparable - Single group was younger and closer to menopause
\end{tabular}

Participants women previously treated and failed CT
Anthracycline and Taxane naive
$100 \%$ MBC
Unclear as to whether pre-treatment was as adjuvant treatment or treatment for MBC
Assessable no:
1) $n=19$
2) $n=20$

Interventions

ETO (VP-16) vs V1+A

1) VP- 16 - slow infusion over 30-45 minutes on days $1,3,5$, repeated every $4-5$ weeks

2) Vincristine + Adriamycin - 1.5mg V1 IV on days 1 and 2 and A $45 \mathrm{mg} / \mathrm{m} 2$ IV on day 3

Treatment repeated every 4-5 weeks

All drug dosages adjusted to produce adequate but clinically tolerable effects

No survival curves or TTP curves
Response (PR only)
1) $2 / 19$
2) $4 / 20$
Toxicity:
Leukopenia
1) $16 / 19$
2) $18 / 20$
Alopecia
1) $17 / 19$
2) $19 / 20$
Toxic death
1) 0
2) 1 (CNS Haemorrhage)
Not ITT - 42 patients entered the trial - 3 patients disqualified post randomisation due to protocol viola-
tions. Randomised numbers not provided by group
Crossover on treatment failure

\section{Risk of bias}


Eagan RT 1976 (Continued)

Bias

\section{Authors' judgement Support for judgement}

Not reported states 'partially randomised'

Random sequence genera- Unclear risk

tion (selection bias)

Allocation concealment $\quad$ Unclear risk
(selection bias)

\begin{tabular}{lll}
\hline $\begin{array}{l}\text { Incomplete outcome data } \\
\text { (attrition bias) }\end{array}$ & High risk & Some missing outcome data but not en \\
All outcomes & & \\
\hline $\begin{array}{l}\text { Selective reporting (re- } \\
\text { porting bias) }\end{array}$ & High risk & The study fails to report survival or TTP
\end{tabular}

\section{Ejlertsen B 2004}

\section{Study characteristics}

\begin{tabular}{|c|c|}
\hline Methods & $\begin{array}{l}\text { Accrual (February } 1995 \text { - January 1999) } \\
\text { RCT - } 15 \text { departments Scandanavia } \\
\text { Randomisation performed centrally and stratified by centre } \\
\text { Patient and tumour characteristics comparable at baseline }\end{array}$ \\
\hline Participants & $\begin{array}{l}387 \text { women with histologically proven metastatic breast cancer. } \\
\text { Anthracycline and cytotoxic naïve } \\
100 \% \text { MBC } \\
100 \% \text { Firstline } \\
\text { Randomised no: } \\
\text { 1) } n=194 \\
\text { 2) } n=193\end{array}$ \\
\hline Interventions & $\begin{array}{l}\text { E vs } E+V 3 \\
\text { 1) Epirubicin } 90 \mathrm{mg} \mathrm{m} 2 \text { day } 1 \text { every } 3 / 52 \\
\text { 2) Epirubicin } 90 \mathrm{mg} / \mathrm{m} 2 \text { day } 1 \text { every } 3 / 52 \\
+ \text { Vinorelbine } 25 \mathrm{mg} / \mathrm{m} 2 \text { days } 1 \text { and } 8 \text { every } 3 / 52\end{array}$ \\
\hline Outcomes & $\begin{array}{l}\text { Survival and PFS curve - Kaplan-Meier curves. } \\
\text { Median survival } \\
\text { 1) } 8.2 \text { months } \\
\text { 2) } 10.1 \text { months } \\
\text { OR (CR+PR) } \\
\text { 1) } 81 / 194 \\
\text { 2) } 96 / 193 \\
\text { Toxicity } \\
\text { Leukopenia } \\
\text { 1) } 23 / 194 \\
\text { 2) } 97 / 193 \\
\text { Nausea/vomiting } \\
\text { 1) } 41 / 194 \\
\text { 2) } 12 / 193\end{array}$ \\
\hline
\end{tabular}


Ejlertsen B 2004 (Continued)
Toxic death
1) 3 (febrile neutropenia, sepsis)
2) 7 (febrile neutropenia, sepsis +1 (cardiac toxicity)

Fotes
F/U PFS min $1 \mathrm{mth}-\max 36 \mathrm{mths}$
ITT
Toxicity - 7 patients were never treated but it is not known which group they came from,

\section{Risk of bias}

\begin{tabular}{lll}
\hline Bias & Authors' judgement & Support for judgement \\
\hline $\begin{array}{l}\text { Random sequence genera- } \\
\text { tion (selection bias) }\end{array}$ & Low risk & Randomised using a central randomisation centre \\
\hline $\begin{array}{l}\text { Allocation concealment } \\
\text { (selection bias) }\end{array}$ & Low risk & Centrally randomised \\
\hline $\begin{array}{l}\text { Incomplete outcome data } \\
\text { (attrition bias) }\end{array}$ & High risk & $\begin{array}{l}\text { Intent to treat analysis stated however seven patients were never treated and } \\
\text { are not included in the analysis for toxicity. }\end{array}$ \\
\hline $\begin{array}{l}\text { Selective reporting (re- } \\
\text { porting bias) }\end{array}$ & Low risk & All expected outcomes reported \\
\hline
\end{tabular}

\section{Erkisi M 1997}

\section{Study characteristics}

\begin{tabular}{|c|c|}
\hline Methods & $\begin{array}{l}\text { Accrual (March 1992- March 1994) } \\
\text { RCT - Turkey, multi-centre } \\
\text { Randomisation not described }\end{array}$ \\
\hline Participants & $\begin{array}{l}60 \text { patients with metastatic } B C \text { or recurrent } B C \text {, histologically proven and measurable disease } \\
\text { Anthracycline naive } \\
100 \% M B C \\
48 \% \text { Firstline } \\
\text { Randomised no: } \\
\text { 1) } n=30 \text { (median age } 52 \text {; range } 26-69 \text { ) } \\
\text { 2) } n=30 \text { (median age } 47 \text {; range } 24-66 \text { ) }\end{array}$ \\
\hline Interventions & $\begin{array}{l}\text { ETO vs FAC } \\
\text { 1)Etoposide } 200 \mathrm{mg} / \text { day op for } 5 \text { days, every } 3 \text { weeks } \\
\text { 2)Fluorouracil } 500 \mathrm{mg} / \mathrm{m} 2 \text { iv every } 3 \text { weeks } \\
+ \text { Doxorubicin } 50 \mathrm{mg} / \mathrm{m} 2 \text { iv every } 3 \text { weeks } \\
+ \text { Cyclophosphamide } 500 \mathrm{mg} / \mathrm{m} 2 \text { iv every } 3 \text { weeks }\end{array}$ \\
\hline Outcomes & $\begin{array}{l}\text { No survival curves or TTP curves provided - survival data assessed by life table method and Mantel-Cox } \\
\text { test } \\
\text { Median survival } \\
\text { 1) } 16 \mathrm{mths} \\
\text { 2) } 14 \mathrm{mths}\end{array}$ \\
\hline
\end{tabular}


Erkisi M 1997 (Continued)

OR (CR and PR):

1) $16 / 30$

2) $12 / 30$

Toxicities of interest not reported -

Toxic death

1) 0

2) 1 (granulcytopenia and infection)

Notes

\section{Risk of bias}

Bias Authors' judgement Support for judgement

Random sequence genera- Unclear risk Not reported

tion (selection bias)

\begin{tabular}{|c|c|c|}
\hline $\begin{array}{l}\text { Allocation concealment } \\
\text { (selection bias) }\end{array}$ & Unclear risk & Not reported \\
\hline $\begin{array}{l}\text { Incomplete outcome data } \\
\text { (attrition bias) } \\
\text { All outcomes }\end{array}$ & Low risk & No missing outcome data \\
\hline $\begin{array}{l}\text { Selective reporting (re- } \\
\text { porting bias) }\end{array}$ & High risk & All expected outcomes reported \\
\hline
\end{tabular}

\section{Falkson G 1990}

\section{Study characteristics}

\begin{tabular}{ll}
\hline Methods & $\begin{array}{l}\text { Accrual (May 1973 -May 1977) } \\
\text { RCT - Multi centre randomisation not described -stratified according to institution } \\
\text { Baseline comparability not discussed }\end{array}$ \\
\hline Participants & 111 women. No prior treatment, $<50 y r s$ \\
& $100 \%$ MBC \\
$100 \%$ Firstline & \\
& Randomised no: \\
1) $n=54$ \\
2) $n=57$ \\
Assessable no: \\
1) $n=51$ (3 ineligible) \\
2) $n=52$ (5 ineligible)
\end{tabular}

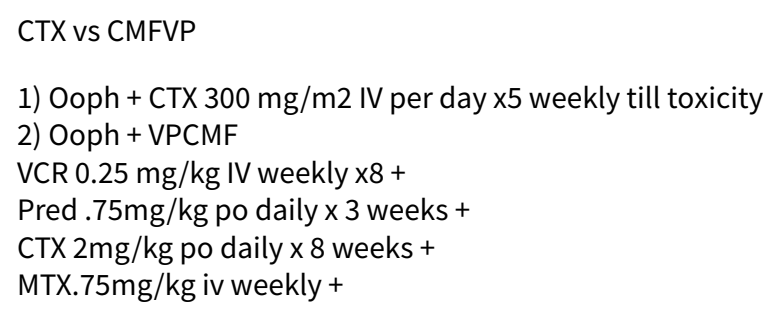


Falkson G 1990 (Continued)

$$
5-F U 12 \mathrm{mg} / \mathrm{kg} \text { IV weekly } \times 8
$$

Outcomes Survival curve - Kaplan-Meier - estimated from randomisation or Ooph- not really clear. No TTP curve. TTF curve excluded.

Median survival

1) $30 \mathrm{mths}$

2) $26 \mathrm{mths}$

Median TTP

1) $14 \mathrm{mths}$

2) $12 \mathrm{mths}$

CR

1) $17 / 51$

2) $19 / 52$

Toxicity

Nausea/vomiting

1) $2 / 51$

2) $6 / 52$

WCC

1) $48 / 51$

2) $22 / 52$

Notes $\quad$ FU min 46 - max 179 mths (reported in text)

Report on three studies - Cancer and Leukaemia Group B (CALGB 7382) is the only single versus combination (with oophorectomy)

\section{Risk of bias}

\section{Bias}

Authors' judgement Support for judgement

Random sequence genera- Unclear risk Not reported

tion (selection bias)

\begin{tabular}{lll}
\hline $\begin{array}{l}\text { Allocation concealment } \\
\text { (selection bias) }\end{array}$ & Unclear risk & Not reported \\
\hline
\end{tabular}

Incomplete outcome data Unclear risk

(attrition bias)

Three patients from the single arm and five from the combination arm were

All outcomes deemed ineligible after entering the trial and were not included in the analyses

Selective reporting (re- Unclear risk All expected outcomes reported
porting bias)

\section{Fraser S 1993}

\section{Study characteristics}

$\begin{array}{ll}\text { Methods } & \text { Accrual (Oct 1988- Dec 1989) } \\ \text { RCT - randomisation not described } \\ 2 \text { centres UK } \\ \text { Groups well balanced except for age - which was not statistically significantly different }\end{array}$


Fraser S 1993 (Continued)

Participants
40 women with advanced breast cancer including histologically proven locally advanced disease, rapidly progressing primary disease and metastatic disease failing to respond to hormonal measures

Randomised no:

1) $n=21$ (median age $52 ; 26-80$ )

2) $n=19$ (median age 63; 39-84)

E vs CMF
$\begin{aligned} & \text { 1) Epirubicin } 20 \mathrm{mg} \text { IV into fast running } 0.9 \% \text { saline every } 7 \text { days } \\ & \text { 2) Cyclophosphamide } 100 \mathrm{mg} / \mathrm{m}-2 \text { orally on day } 1-14 \text {, Methotrexate } 35 \mathrm{mg} / \mathrm{m}-2 \mathrm{IV} \text { on days } 1 \text { and } 8 \text { and } 5 \\ & \text { Fluorouracil } 600 \mathrm{mg} / \mathrm{m}-2 \text { IV on days } 1 \text { and } 8 \text {, on a } 28 \text { day cycle (CMF) }\end{aligned}$

\begin{tabular}{|c|c|}
\hline Outcomes & $\begin{array}{l}\text { Survival curve - Kaplan-Meier life table method - survival analysed from start of treatment to last event } \\
\text { on the curve. } \\
\text { No TTP curve } \\
\text { Median survival } \\
\text { 1) } 55 \text { weeks } \\
\text { 2) } 57 \text { weeks } \\
\text { Median TTP } \\
\text { 1) } 7 \text { weeks } \\
\text { 2) } 24 \text { weeks } \\
\text { OR (CR + PR) } \\
\text { 1) } 6 / 21 \\
\text { 2) } 11 / 19 \\
\text { Toxicity not available by group. CMF caused more alopecia, nausea and vomiting and haematological } \\
\text { toxicity (above grade 1) } \\
\text { There were no fatalities } \\
\text { Three QOL measures - LASA, NHP, Qualitator - well described }\end{array}$ \\
\hline Notes & $\begin{array}{l}\text { F/U min } 6 \text { mth -max } 27 m \text { ths (based on curves) } \\
\text { ITT for response/TTTF }\end{array}$ \\
\hline & Excluded from firstline analysis as contained locally advanced cases \\
\hline
\end{tabular}

\section{Risk of bias}

\begin{tabular}{lll}
\hline Bias & Authors' judgement & Support for judgement \\
\hline $\begin{array}{l}\text { Random sequence genera- } \\
\text { tion (selection bias) }\end{array}$ & Unclear risk & States 'randomised' \\
\hline $\begin{array}{l}\text { Allocation concealment } \\
\text { (selection bias) }\end{array}$ & Unclear risk & Not reported \\
\hline $\begin{array}{l}\text { Incomplete outcome data } \\
\begin{array}{l}\text { (attrition bias) } \\
\text { All outcomes }\end{array}\end{array}$ & Low risk & No missing outcome data \\
\hline $\begin{array}{l}\text { Selective reporting (re- } \\
\text { porting bias) }\end{array}$ & Low risk & All expected outcomes reported \\
\hline
\end{tabular}


French Epi (A) 1991

\section{Study characteristics}

Methods RCT - Randomisation not described - Stratified on the basis of bone mets/or not

Multi centre 13 institutions, France

Baseline - More lymph node mets in the FEC50 combination group

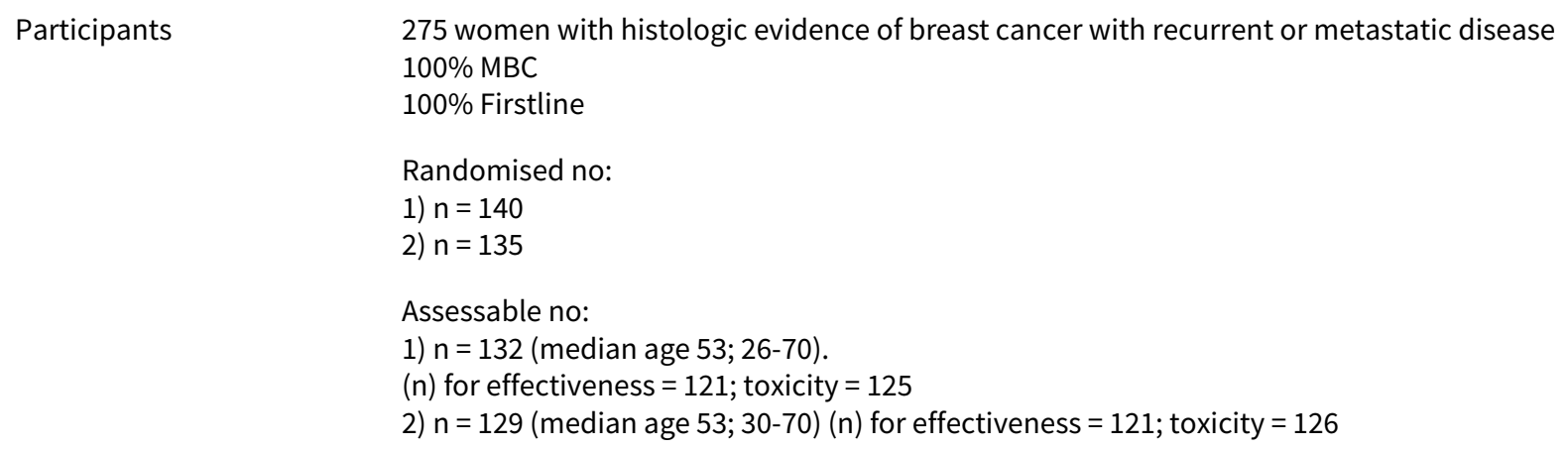

Enterventions
$\begin{aligned} & \text { 1) Epirubicin } 75 \mathrm{mg} / \mathrm{m} 2 \text { iv } \\ & \text { 2) FEC } 50 \\ & \text { Epirubicin } 50 \mathrm{mg} / \mathrm{m} 2 \text { iv day } 1 \times 21 \text { day cycle } \\ & +5 \text {-Flurouracil } 500 \mathrm{mg} / \mathrm{m} 2 \mathrm{iv} \\ & + \text { Cyclophosphamide } 500 \mathrm{mg} / \mathrm{m} 2 \\ & \text { (All treatments repeated every } 21 \text { days) }\end{aligned}$

Outcomes Survival curve - Kaplan-Meier method - ? from randomisation or? from treatment TTF curve provided however as authors report this as TTP, this has been included

$\mathrm{OR}(\mathrm{CR}+\mathrm{PR})$

1) $37 / 121$ duration of response $=315$ days (range $84-1107$ )

2) $54 / 121$ duration of response $=378$ days (range $84-1008$ )

Toxicity

Treatment ceased due to cardiac toxicity in 15 patients ( 7 in the single group; 3 in the combination group)

Nausea and vomiting and granulopenia reported by percentage of total cycles of chemotherapy

Toxic death- NR six cases of cardiac failure - all controlled by symptomatic treatment

\section{Risk of bias}

\begin{tabular}{lll}
\hline Bias & Authors' judgement & Support for judgement \\
\hline $\begin{array}{l}\text { Random sequence genera- } \\
\text { tion (selection bias) }\end{array}$ & Unclear risk & Not reported \\
\hline $\begin{array}{l}\text { Allocation concealment } \\
\text { (selection bias) }\end{array}$ & Unclear risk & Not reported \\
\hline $\begin{array}{l}\text { Incomplete outcome data } \\
\text { (attrition bias) } \\
\text { All outcomes }\end{array}$ & Low risk & Missing outcome data well balanced between the groups \\
\hline
\end{tabular}


French Epi (A) 1991 (Continued)

Selective reporting (re- Low risk All expected outcomes reported porting bias)

French Epi (B) 1991

\section{Study characteristics}

\begin{tabular}{ll}
\hline Methods & RCT - Randomisation not described - Stratified on the basis of bone mets/or not \\
Multi centre 13 institutions, France \\
Baseline comparability
\end{tabular}

$\begin{array}{ll}\text { Interventions } & \text { E vs FEC } 75 \\ & \text { 1) Epirubicin } 75 \mathrm{mg} / \mathrm{m} 2 \text { iv vs } \\ & \text { 2) FEC } 75 \\ & \text { Epirubicin } 75 \mathrm{mg} / \mathrm{m} 2 \\ & + \text { Cyclophosphamide } 500 \mathrm{mg} / \mathrm{m} 2 \text { iv day } 1 \times 21 \text { day cycle } \\ & +5 \text {-Flurouracil } 500 \mathrm{mg} / \mathrm{m} 2 \text { iv day } \\ & \text { (All treatments repeated every } 21 \text { days) }\end{array}$

\begin{tabular}{|c|c|c|}
\hline \multirow[t]{8}{*}{ Outcomes } & \multicolumn{2}{|c|}{ Survival and TTP curve - Kaplan-Meier method - ? from randomisation or? from treatment } \\
\hline & \multicolumn{2}{|l|}{$O R(C R+P R)$} \\
\hline & \multirow{2}{*}{\multicolumn{2}{|c|}{$\begin{array}{l}\text { 1) } 37 / 121 \text { duration of response }=315 \text { days (range } 84-1107 \text { ) } \\
\text { 2) } 55 / 123 \text { duration of response }=395 \text { days (range } 22-1139 \text { ) }\end{array}$}} \\
\hline & & \\
\hline & \multicolumn{2}{|l|}{ Toxicity } \\
\hline & \multirow{2}{*}{\multicolumn{2}{|c|}{$\begin{array}{l}\text { Treatment ceased due to cardiac toxicity in } 15 \text { patients ( } 7 \text { in the single group; } 5 \text { in the combination } \\
\text { group) } \\
\text { Nausea and vomiting and granulopenia reported by percentage of total cycles of chemotherapy } \\
\text { Toxic death - NR }\end{array}$}} \\
\hline & & \\
\hline & \multicolumn{2}{|c|}{ Six cases of cardiac failure - all controlled by symptomatic treatment } \\
\hline Notes & \multirow{2}{*}{\multicolumn{2}{|c|}{$\begin{array}{l}\text { F/U survival min } 8 \mathrm{mths} \text { (based on cycles) - max - } 40 \mathrm{mths} \text { ( } 1200 \text { days reported from curves) } \\
\text { F/U TTP min } 4 \mathrm{mths} \text { - max } 40 \mathrm{mth} \text { based on curve }\end{array}$}} \\
\hline & & \\
\hline \multicolumn{3}{|l|}{ Risk of bias } \\
\hline Bias & Authors' judgement & Support for judgement \\
\hline $\begin{array}{l}\text { Random sequence genera- } \\
\text { tion (selection bias) }\end{array}$ & Unclear risk & Not reported \\
\hline $\begin{array}{l}\text { Allocation concealment } \\
\text { (selection bias) }\end{array}$ & Unclear risk & Not reported \\
\hline
\end{tabular}


French Epi (B) 1991 (Continued)

Incomplete outcome data Low risk Missing outcome data well balanced between the groups (attrition bias)

All outcomes

Selective reporting (re- Unclear risk $\quad$ All expected outcomes reported
porting bias)

\section{GEICAM 2007}

\section{Study characteristics}

$\begin{array}{ll}\text { Methods } & \text { Accrual (January } 2001 \text { - March } 20050 \\ \text { RCT - Randomisation generated by computer generated random code } \\ \text { Multi-centre, six countries } \\ \text { Stratified by centre, number of treatment lines for MBC } \\ \text { Baseline comparibility }\end{array}$

\begin{tabular}{|c|c|}
\hline \multirow[t]{3}{*}{ Participants } & $\begin{array}{l}252 \text { women with histologically confirmed locally recurrent and metastatic breast cancer not amenable } \\
\text { to curative surgery or radiotherapy } \\
\text { At least } 75 \% \text { MBC } \\
36 \% \text { first line - previously treated with anthracyclines and taxanes }\end{array}$ \\
\hline & $\begin{array}{l}\text { Randomised no: } \\
\text { 1) } n=127 \text { (median age } 57 ; 35-80) \\
\text { 2) } n=125 \text { (median age } 58 ; 28-82)\end{array}$ \\
\hline & $\begin{array}{l}\text { Assessable no: } \\
\text { 1) } n=126-1 \text { patient previously treated with vinorelbine } \\
\text { 2) } n=125\end{array}$ \\
\hline Interventions & $\begin{array}{l}\text { V3 versus } V 3+\mathrm{Gem} \\
\text { 1) Vinorelbine } 30 \mathrm{mg} / \mathrm{m} 2 \text { IV days } 1 \text { and } 8 \\
\text { 2) Vinorelbine } 30 \mathrm{mg} / \mathrm{m} 2 \text { IV days } 1 \text { and } 8+\text { Gemcitabine } 1200 \mathrm{mg} / \mathrm{m} 2 \text { IV days } 1 \text { and } 8 \\
\text { Treatment cycle } 21 \text { days }\end{array}$ \\
\hline Outcomes & $\begin{array}{l}\text { PFS curve. No OS curve } \\
\text { Median survival } \\
\text { 1) } 16.4 \text { months (11.6-21) } \\
\text { 2) } 15.9 \text { months (12.6-19.1) } \\
\text { Median PFS } \\
\text { 1) } 4 \text { months (2.9-5.1) } \\
\text { 2) } 6 \text { months (4.8-7.1) } \\
\text { OR (CR+PR) } \\
\text { 1) } 33 / 126 \\
\text { 2) } 45 / 125 \\
\text { Toxicity (WHO 3/4) } \\
\text { Nausea/vomiting } \\
\text { 1) } 3 / 125 \\
\text { 2) } 4 / 123 \\
\text { Neutropenia } \\
\text { 1) } 55 / 125 \\
\text { 2) } 75 / 123\end{array}$ \\
\hline
\end{tabular}


GEICAM 2007 (Continued)
Alopecia
1) $21 / 125$
2) $21 / 123$
Toxic death
1) $n=1$ (acute liver failure)
2) $n=1$ (septic shock)

\begin{tabular}{ll}
\hline Notes & FU 1-25 months (estimated from curve) \\
& Trial unblinded \\
& Analysis ITT
\end{tabular}

\section{Risk of bias}

\begin{tabular}{lll}
\hline Bias & Authors' judgement & Support for judgement \\
\hline $\begin{array}{l}\text { Random sequence genera- } \\
\text { tion (selection bias) }\end{array}$ & Low risk & $\begin{array}{l}\text { Centrally randomised at the GEICAM headquarters using computer generated } \\
\text { random code }\end{array}$ \\
\hline $\begin{array}{l}\text { Allocation concealment } \\
\text { (selection bias) }\end{array}$ & Low risk & Central randomisation \\
\hline $\begin{array}{l}\text { Incomplete outcome data } \\
\text { (attrition bias) } \\
\text { All outcomes }\end{array}$ & Low risk & No missing outcome data \\
\hline $\begin{array}{l}\text { Selective reporting (re- } \\
\text { porting bias) }\end{array}$ & Low risk & All expected outcomes reported \\
\hline
\end{tabular}

\section{Gundersen S 1986}

\section{Study characteristics}

\begin{tabular}{|c|c|}
\hline Methods & $\begin{array}{l}\text { Accrual (June 1982- December 1983) } \\
\text { RCT - Allocation by random number generation - no stratification } \\
\text { Norway - multi-centre } \\
\text { Groups well balanced according to age, disease free interval and time from first metastases to ran- } \\
\text { domisation }\end{array}$ \\
\hline Participants & $\begin{array}{l}128 \text { women with metastatic BC, histologically proven with evaluable lesions } \\
\text { Those previously treated with Adriamycin were excluded - all were hormone resistant- } \\
100 \% \text { MBC } \\
100 \% \text { Firstline } \\
\text { Randomised no: } \\
\text { 1) } n=62 \text { (Mean age } 59 \text { ) } \\
\text { 2) } n=66 \text { (Mean age } 56 \text { ) }\end{array}$ \\
\hline Interventions & $\begin{array}{l}\text { A vs V1+A+C } \\
\text { 1) Doxorubicin } 20 \mathrm{mg} / \text { week to max dose } 750 \mathrm{mg} / \mathrm{m} 2 \\
\text { 2) Vincristine } 2 \mathrm{mg} \\
+ \text { Adriamycin } 50 \mathrm{mg} / \mathrm{m} 2 \text { to } \mathrm{max} \text { dose } 500 \mathrm{mg} / \mathrm{m} 2 \\
+ \text { Cyclophosphamide } 600 \mathrm{mg} / \mathrm{m} 2 \\
\text { (VAC every } 3 \text { weeks) }\end{array}$ \\
\hline
\end{tabular}


Gundersen S 1986 (Continued)

Outcomes
Overall survival curves calculated by actuarial life table method - survival calculated from start of treatment

No TTP curves

Mean TTF

1) $33 \mathrm{mths}$

2) $29 \mathrm{mths}$

$\mathrm{OR}(\mathrm{CR}+\mathrm{PR})$

1) $19 / 62$

2) $24 / 66$

Toxicity WHO 3

Vomiting

1) $4 / 62$

2) $43 / 66$

Alopecia

1) $5 / 62$

2) $52 / 66$

Toxic death - NR

$\mathrm{F} / \mathrm{U}$ min $3 \mathrm{mths}$ (based on first assessment of response or review of treatment)- max $24 \mathrm{mths}$ (from survival curve

ITT -

\section{Risk of bias}

\begin{tabular}{|c|c|c|}
\hline Bias & Authors' judgement & Support for judgement \\
\hline $\begin{array}{l}\text { Random sequence genera- } \\
\text { tion (selection bias) }\end{array}$ & Low risk & Allocation by random number generation \\
\hline $\begin{array}{l}\text { Allocation concealment } \\
\text { (selection bias) }\end{array}$ & Low risk & Not reported \\
\hline $\begin{array}{l}\text { Incomplete outcome data } \\
\text { (attrition bias) } \\
\text { All outcomes }\end{array}$ & Low risk & No missing outcome data \\
\hline $\begin{array}{l}\text { Selective reporting (re- } \\
\text { porting bias) }\end{array}$ & Low risk & All expected outcomes reported \\
\hline
\end{tabular}

Heidemann E 2002

\section{Study characteristics}

\begin{tabular}{ll}
\hline Methods & Accrual (1992-1997) \\
RCT - Random number generation - central statistical institute - stratified according to disease free \\
state and metastases \\
Germany, multi-centre \\
Groups well balanced except for receptor status
\end{tabular}

Participants 260 women with measurable metastatic $B C$ fulfilling high risk criteria previously untreated for MBC Histologically documented ABC stage IV Anthracycline naive 
Heidemann E 2002 (Continued)

$100 \% \mathrm{MBC}$

100\% Firstline

Randomised no:

1) 127

2) 133

Evaluable for efficacy and QOL

1) 119

2) 119

Evaluable for toxicity

1) 131

2) 125

\begin{tabular}{ll}
\hline Interventions & MZA vs FEC \\
& 1) Mitoxantrone $12 \mathrm{mg} / \mathrm{m} 2$ IV by short infusion x21 days \\
2) FEC & 5-Flurouracil $500 \mathrm{mg} / \mathrm{m} 2 \mathrm{IV}$ \\
& + Epirubicin $50 \mathrm{mg} / \mathrm{m} 2$ \\
& + Cyclophosphamide $500 \mathrm{mg} / \mathrm{m} 2$ \\
& IV every 3 weeks, max 12 cycles \\
& 2nd and 3rd line treatment fixed
\end{tabular}

Survival and TTP curves - Kaplan-Meier life table method - from commencement of treatment
Median survival
1) 14.1 mths
2) 15.8 mths
Median TTP
1) 4.4 mths
2) 6.15
OR (CR + PR)
1) $30 / 119$
2) $43 / 119$
Toxicity (WHO 3-4)
Nausea /vomiting
1) $9 / 131$
2) $37 / 125$
Alopecia
1) $6 / 131$
2) $77 / 125$
Toxic death - NR
QOL - Brunners score

Notes $\quad$ F/U survival and TTP $\min 0.99-\max 73.68 \mathrm{mths}$ (Stated in text)

\section{Risk of bias}

Authors' judgement Support for judgement

Random sequence genera- Low risk Random number generation tion (selection bias) 
Heidemann E 2002 (Continued)

Allocation concealment Low risk $\quad$ Centrally randomised
(selection bias)

Incomplete outcome data Low risk

(attrition bias)

All outcomes

Selective reporting (re- Low risk All expected outcomes reported
porting bias)

Quorum of missing patients provided - balanced across both groups unlikely to have a clinically relevant impact

\section{Heidemann E 2004}

\section{Study characteristics}

\begin{tabular}{ll}
\hline Methods & Accrual June 1997- December 2001 \\
RCT Phase IV \\
Randomisation by central fax/phone in blocks of variable length. Stratified by institution \\
Germany, multi-centre \\
Demographic and prognostic criteria generally similar in both arms except that more patients had a \\
Disease free interval </=18months in the single agent arm \\
179 women with histologically proven MBC (High risk); at least one measurable lesion, WHO perfor- \\
mance status 0-2, adequate hematologic, renal and hepatic function. \\
High \\
Participants \\
100\% MBC \\
Randomised no: \\
1) $n=89$ \\
2) $n=90$ \\
ITT 176 \\
1) $n=87$ \\
2) $n=89$
\end{tabular}

Interventions M vs M+TXT

1) Mitoxantrone $12 \mathrm{mg} / \mathrm{m} 2$ IV on day 1 every 3 weeks until complete response (plus 2 cycles) progressive disease or cumulative dose of $160 \mathrm{mg} / \mathrm{m} 2$

2) Mitoxantrone $12 \mathrm{mg} / \mathrm{m} 2$ IV on day 1 every 3 weeks plus docetaxel $80 \mathrm{mg} / \mathrm{m} 2$ as a 1 hour infusion on day 1 every 3 weeks for a maximum of 6 cycles

\section{Outcomes}

OS and PFS curves- from date of randomisation until progressive disease, death or last contact

$$
\begin{aligned}
& \text { Median survival } \\
& \text { 1) } 15.6 \text { months } \\
& \text { 2) } 17.2 \text { months } \\
& \text { Median TTP } \\
& \text { 1) } 4.9 \text { months } \\
& \text { 2) } 8.0 \text { months } \\
& \text { OR (CR+PR) } \\
& \text { 1) } 20 / 86 \\
& \text { 2) } 441 / 87 \\
& \text { Toxicity (WHO } 3 / 4 \text { ) } \\
& \text { Nausea/vomiting }
\end{aligned}
$$


Heidemann E 2004 (Continued)
1) $5 / 85$
2) $5 / 85$
Leukopenia
1) $53 / 85$
2) $76 / 85$
Toxic death - NR

$\begin{array}{ll}\text { Notes } & \text { F/U Median } 43.6 \text { months stated } \\ & \text { Text states } 176 \text { patients ITT analyses (1 excluded due to cerebral metastases; } 2 \text { insufficient data) }\end{array}$

\section{Risk of bias}

\begin{tabular}{lll}
\hline Bias & Authors' judgement & Support for judgement \\
\hline $\begin{array}{l}\text { Random sequence genera- } \\
\text { tion (selection bias) }\end{array}$ & Unclear risk & Random number generation \\
\hline
\end{tabular}

\begin{tabular}{lll}
\hline $\begin{array}{l}\text { Allocation concealment } \\
\text { (selection bias) }\end{array}$ & Low risk & Centrally randomised \\
\hline $\begin{array}{l}\text { Incomplete outcome data } \\
\text { (attrition bias) } \\
\text { All outcomes }\end{array}$ & Low risk & No missing outcome data \\
\hline $\begin{array}{l}\text { Selective reporting (re- } \\
\text { porting bias) }\end{array}$ & Low risk & All expected outcomes reported \\
\hline
\end{tabular}

\section{Hoogstraten $B(A) 1976$}

\section{Study characteristics}

\begin{tabular}{|c|c|}
\hline Methods & $\begin{array}{l}\text { Accrual (Jan } 1972 \text { - Feb 1974) } \\
\text { RCT - Initial randomisation into three treatment groups with non compulsory 'crossover' following re- } \\
\text { lapse or failure to respond - method not described } \\
\text { North America, multi-centre }\end{array}$ \\
\hline Participants & $\begin{array}{l}177 \text { women with measurable MBC } \\
100 \% \text { MBC } \\
100 \% \text { Firstline } \\
\text { Assessable no: } \\
\text { 1) } n=79 \\
\text { 2) } n=98\end{array}$ \\
\hline Interventions & $\begin{array}{l}\text { A vs CMFVP-(Intermittent) } \\
\text { 1) Doxorubicin } 60 \mathrm{mg} / \mathrm{m} 2 \text { iv every } 3 \text { weeks } \\
\text { 2) Intermittent - } \\
\text { Vincristine } 0.625 \mathrm{mg} / \mathrm{m} 2 / \text { iv days } 1 \text { and } 5 \\
+ \text { Methotgrexate } 4 \mathrm{mg} / \mathrm{m} 2 / \text { iv dx5 } \\
+5 \text {-Flurouracil } 180 \mathrm{mg} / \mathrm{m} 2 / \text { iv dx } 5 \\
\text { + Cyclophosphamide } 120 \mathrm{mg} / \mathrm{m} 2 \text { iv dx } 5 \\
+ \text { Prednisone } 40 \mathrm{mg} / \mathrm{m} 2 / \text { day X } 5 \\
\text { then crossover }\end{array}$ \\
\hline Outcomes & No OS or TTP curves \\
\hline
\end{tabular}


Hoogstraten B(A)1976 (Continued)

\author{
$\mathrm{OR}(\mathrm{CR}+\mathrm{PR})$ \\ 1) $31 / 79$ (median duration of response $4 \mathrm{mths}$ ) \\ 2) $39 / 98$ (median duration of response $10 \mathrm{mths}$ ) \\ Toxicity (WHO 3-4) \\ Leukopenia \\ 1) $24 / 79$ \\ 2) $40 / 98$ \\ Alopecia \\ 1) $47 / 79$ \\ 2) $5 / 98$
}

Toxic death not included as numbers cited in text and tables are inconsistent

Notes

Not ITT - Of the reported accrual numbers $(n=297) 14$ (across all 3 arms of the trial) were not evaluable and not analysed due to protocol violations and lack of adequate data.

Randomised numbers not reported by group. Phase I only considered in this review

Arm 1 versus Arm 2 -Leukopenia was the dose limiting response

\title{
Risk of bias
}

Bias Authors' judgement Support for judgement

Random sequence genera- Unclear risk States 'randomised'

tion (selection bias)

\begin{tabular}{lll}
\hline $\begin{array}{l}\text { Allocation concealment } \\
\text { (selection bias) }\end{array}$ & Unclear risk & Not reported \\
\hline $\begin{array}{l}\text { Incomplete outcome data } \\
\text { (attrition bias) }\end{array}$ & High risk & $\begin{array}{l}14 \text { (across all } 3 \text { arms of the trial) were not evaluable and not analysed due to } \\
\text { protocol violations and lack of adequate data. }\end{array}$
\end{tabular}

All outcomes

Selective reporting (re- High risk All expected outcomes not reported porting bias)

Hoogstraten B(B)1976

Study characteristics

\begin{tabular}{ll}
\hline Methods & Accrual (Jan 1972 - Feb 1974) \\
& RCT - Initial randomisation into three treatment groups with non compulsory 'crossover' following re- \\
lapse or failure to respond - method not described & North America, multi-centre \\
\hline Participants & 185 women with measurable MBC \\
$100 \%$ MBC \\
$100 \%$ Firstline \\
Assessable no: \\
1) $n=79$ \\
2) $n=106$ \\
\hline A vs CMFVP- (Weekly) \\
1) Doxorubicin $60 \mathrm{mg} / \mathrm{m} 2$ iv every 3 weeks \\
\hline
\end{tabular}


Hoogstraten B(B)1976 (Continued)

\section{2) Weekly}

Vincristine $0.625 \mathrm{mg} / \mathrm{m} 2 /$ week iv

+ Methotrexate $15 \mathrm{mg} / \mathrm{m} 2 / \mathrm{wk}$ iv

+ 5-Flurouracil $300 \mathrm{mg} / \mathrm{m} 2 / \mathrm{wk}$ iv

+ Cyclophosphamide $60 \mathrm{mg} / \mathrm{m} 2 /$ day po

+ Prednisone $30 \mathrm{mg} / \mathrm{m} 2 /$ day X 14

$20 \mathrm{mg} / \mathrm{m} 2 /$ day $X 14$

$10 \mathrm{mg} / \mathrm{m} 2 /$ day

then crossover

Outcomes
No OS or TTP curves
OR (CR+PR)
1) $31 / 79$ (median duration of response $4 \mathrm{mths}$ )
2) $63 / 106$ (median duration of response $8 \mathrm{mths}$ )
Toxicity $3-4$
Leukopenia
1) $24 / 79$
2) $30 / 106$
Alopecia
1) $47 / 79$
2) $13 / 106$

Toxic death not included as numbers cited in text and tables are inconsistent

Notes

Not ITT - Of the reported accrual numbers $(n=297) 14$ (across all 3 arms of the trial) were not evaluable and not analysed due to protocol violations and lack of adequate data.

Randomised numbers not reported by group. Phase I only considered in this review

\section{Risk of bias}

Bias Authors' judgement Support for judgement

Random sequence genera- Unclear risk States 'randomised'

tion (selection bias)

\begin{tabular}{lll}
$\begin{array}{l}\text { Allocation concealment } \\
\text { (selection bias) }\end{array}$ & Unclear risk & Not reported \\
\hline $\begin{array}{l}\text { Incomplete outcome data } \\
\text { (attrition bias) } \\
\text { All outcomes }\end{array}$ & High risk & $\begin{array}{l}14 \text { (across all } 3 \text { arms of the trial) were not evaluable and not analysed due to } \\
\text { protocol violations and lack of adequate data. }\end{array}$ \\
\hline
\end{tabular}

\begin{tabular}{l}
$\begin{array}{l}\text { Selective reporting (re- } \quad \text { High risk } \\
\text { porting bias) }\end{array}$ \\
\hline
\end{tabular}

Icli F 2005

\section{Study characteristics}

$\begin{array}{ll}\text { Methods } & \text { Accrual (December } 1997 \text { - August } 2002 \\ \text { Prospective randomised non blinded multicentre Phase III study } \\ \text { Central randomisation - No stratification for prognostic factors or centres } \\ \text { Baseline comparability: no significant imbalance noted or reported }\end{array}$


Icli F 2005 (Continued)

Participants
201 women with histological or cytological confirmation of locally advanced or metastatic adenocarcinoma of the breast. Measurable disease previously treated with anthracyclines

$96 \%$ MBC

20\% Firstline, 60\% second line, 20\% third line

Randomised no:

1) $n=101$ (Median age 49; 24-70)

2) $n=100$ (Median age $47 ; 26-69$ )

Assessable no:

1) $n=97$

2) $n=96$

Assessable for response:

1) $n=91$

2) $n=94$

Interventions

PACL vs ETO+CDDP

1) Paclitaxel $175 \mathrm{mg} / \mathrm{m} 2$, DI q3 weeks

2) Cisplatin $70 \mathrm{mg} / \mathrm{m} 2 \mathrm{IV}$, DI q3 weeks +oral etoposide $-1650 \mathrm{mg}$ bid, po, D 1-7q 3 weeks

Crossover from single arm $=42$;

Crossover from combination arm $=30$

Crossover was allowed for pts with PD at any stage. Also patients with SD could crossover after two cycles of the allocated treatment

Survival and TTP curves included - Kaplan Meier
Median survival
1) 9.5 mths
2) 14 mths
Median TTP
1) 3.9
2) 5.5 mths
OR (CR+PR)
1) $21 / 94$
2) $33 / 91$
Toxicity WHO 3-4
Nausea
1) $15 / 97$
2) $1 / 96$
Neutropenia
1) $18 / 97$
2) $11 / 96$
Toxic death
1) 3 (2 neutropenia + 1 unknown)
2) 2 (neutropenia)

Notes

F/U survival min 4mths - max 48mths (based on median no. of cycles and last event on the OS curve) F/U TTP min 4mths - max 40mths (based on median no. of cycles and last event on the OS curve) Not ITT - Paper states OS calculated on ITT

\section{Risk of bias}


Icli F 2005 (Continued)

Random sequence genera- Low risk $\quad$ Centrally randomised
tion (selection bias)

Allocation concealment $\quad$ Low risk
(selection bias)

Incomplete outcome data Low risk Missing outcome data balanced across groups
(attrition bias)
All outcomes

\begin{tabular}{l}
$\begin{array}{l}\text { Selective reporting (re- } \\
\text { porting bias) }\end{array}$ \\
\hline
\end{tabular}

Ingle J 1985

\section{Study characteristics}

\begin{tabular}{|c|c|}
\hline Methods & $\begin{array}{l}\text { Accrual (Sept } 1979 \text { - April 1982) } \\
\text { RCT - Randomised according to dynamic allocation scheme - Stratification based on ECOG } \\
\text { North America, multi-centre } \\
\text { Baseline comparability not discussed or reported }\end{array}$ \\
\hline Participants & $\begin{array}{l}158 \text { women with histologic confirmation of breast cancer and progressive metastatic disease } \\
\text { Previous combination chemotherapy but no doxorubicin, anthracycline or mitolactol } \\
100 \% \text { MBC } \\
100 \% \text { Firstline } \\
\text { Randomised no: } \\
\text { 1) } n=79 \\
\text { 2) } n=79 \\
\text { Assessable no: } \\
\text { 1) } n=74 \text { (median age } 59 ; 37-79) \\
\text { 2) } n=77 \text { (median age } 56 ; 32-76 \text { ) }\end{array}$ \\
\hline Interventions & $\begin{array}{l}\text { A vs } A+M T L \\
\text { 1) Doxorubicin } 60 \mathrm{mg} / \mathrm{m} 2 \text { iv day } 1 \times \text { monthly } \\
\text { 2) Doxorubicin } 40 \mathrm{mg} / \mathrm{m} 2 \text { iv day } 1 \times \text { monthly, max } 500 \mathrm{mg} / \mathrm{m} 2 \\
+ \text { Mitolactol } 135 \mathrm{mg} / \mathrm{m} 2 \text { po days } 1-10,180 \mathrm{mg} / \mathrm{m} 2 \text { after max Dox reached. }\end{array}$ \\
\hline Outcomes & $\begin{array}{l}\text { Survival and TTP curves - Kaplan Meier } \\
\text { Median survival } \\
\text { 1) } 232 \text { days } \\
\text { 2) } 225 \text { days } \\
\text { Median TTP } \\
\text { 1) } 186 \text { days } \\
\text { 2) } 178 \text { days } \\
\text { OR (CR+PR) } \\
\text { 1) } 26 / 74 \\
\text { 2) } 25 / 77 \\
\text { Toxicity } \\
\text { Leukopenia } \\
\text { 1) } 62 / 70\end{array}$ \\
\hline
\end{tabular}


Ingle J 1985 (Continued)

\section{2) $53 / 67$}

Nausea and vomiting

1) $11 / 74$

2) $12 / 77$

Alopecia

1) $41 / 74$

2) $26 / 77$

Toxic death

1) 3

2) 0

\section{Notes}

F/U survival and TTP min $1.1 \mathrm{mth}$ estimated from cycles) - max $50 \mathrm{mths}$ (based on events on curve)

Not ITT

\section{Risk of bias}

\begin{tabular}{|c|c|c|}
\hline Bias & Authors' judgement & Support for judgement \\
\hline $\begin{array}{l}\text { Random sequence genera- } \\
\text { tion (selection bias) }\end{array}$ & Low risk & Randomised according to dynamic allocation scheme \\
\hline $\begin{array}{l}\text { Allocation concealment } \\
\text { (selection bias) }\end{array}$ & Unclear risk & Insufficient information \\
\hline $\begin{array}{l}\text { Incomplete outcome data } \\
\text { (attrition bias) } \\
\text { All outcomes }\end{array}$ & Low risk & $\begin{array}{l}\text { Not ITT- five from the single arm and } 2 \text { from the combination arm were dis- } \\
\text { qualified and not included in the analyses however reasonably balanced } \\
\text { across arms }\end{array}$ \\
\hline $\begin{array}{l}\text { Selective reporting (re- } \\
\text { porting bias) }\end{array}$ & Low risk & All expected outcomes reported \\
\hline
\end{tabular}

Ingle J 1989

\section{Study characteristics}

\begin{tabular}{ll}
\hline Methods & Accrual (Nov 1982- Feb 1987) \\
RCT - Randomised dynamic allocation scheme - ECOG $</=3$ Stratified according to score - \\
North America - multi-centre \\
Good balance between groups reported \\
\hline $\begin{array}{l}185 \text { women with histologically confirmed breast and progressive metastatic disease } \\
\text { pre- and postmenopausal } \\
\text { 100\% MBC } \\
\text { Assumed 100\% Firstline } \\
\text { Randomised no: } \\
\text { 1) } n=95 \text { (mean age 58) } \\
\text { 2) } n=90 \text { (mean age 57) } \\
\text { Assessable no: } \\
\text { 1) } n=68 \\
\text { 2) } n=63\end{array}$ \\
\end{tabular}


Ingle J 1989 (Continued)

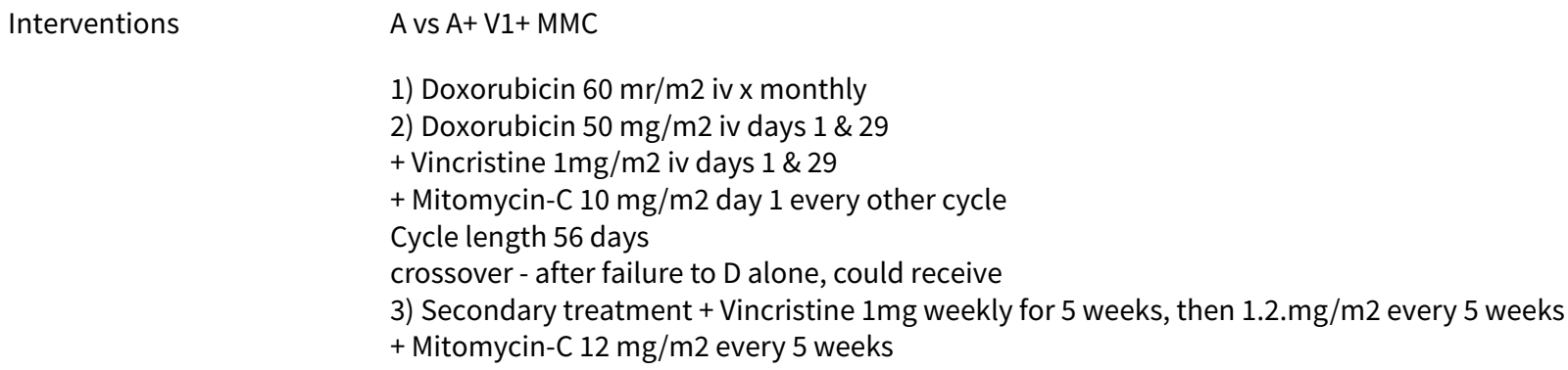

Outcomes
Survival and TTP curve
Median survival
1) 8.4 mths
2) 9.2 mths
Median TTP
1) 2.7 mths
2) 4.2 mths
OR (CR+PR)
1) $24 / 95$
2) $39 / 90$
Toxicity
Leukopenia
1) $61 / 91$
2) $75 / 87$
Nausea and vomiting
1) $30 / 95$
2) $31 / 90$
Toxic death
1) 2
2) 1

Notes

F/U survival min 3mths - max 36mths(based on last event on the curve)

F/U TTP min 3mths - max 24mths (based on last event on the curve)

\section{Risk of bias}

\begin{tabular}{|c|c|c|}
\hline Bias & Authors' judgement & Support for judgement \\
\hline $\begin{array}{l}\text { Random sequence genera- } \\
\text { tion (selection bias) }\end{array}$ & Low risk & Randomised using a dynamic allocation scheme \\
\hline $\begin{array}{l}\text { Allocation concealment } \\
\text { (selection bias) }\end{array}$ & Unclear risk & Insufficient information \\
\hline $\begin{array}{l}\text { Incomplete outcome data } \\
\text { (attrition bias) } \\
\text { All outcomes }\end{array}$ & Low risk & No missing outcome data \\
\hline $\begin{array}{l}\text { Selective reporting (re- } \\
\text { porting bias) }\end{array}$ & Low risk & All expected outcomes reported \\
\hline
\end{tabular}


Joensuu H 1998

\section{Study characteristics}

\begin{tabular}{ll}
\hline Methods & Accrual (July 1991-April 1996) \\
RCT - Centralised randomisation Finnish Cancer registry, Helsinki \\
Stratification according to treatment centre and WHO treatment status \\
Multi-centre - Finland \\
Groups well balanced on all variables
\end{tabular}

Participants

303 women with histologically verified breast cancer that had given rise to distant metastases $100 \%$ firstline

Randomised no:

1) $n=153$ (median age $56 ; 33-72$ )

2) $n=150$ (median age $55 ; 26-72$ )

Assessable for response:
1) $n=140$
2) $n=143$

Assessible for toxicity:

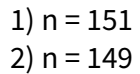

Interventions

\section{E vs $\mathrm{E}+\mathrm{C}+\mathrm{F}$}

1)Epirubicin $20 \mathrm{mg} / \mathrm{m} 2$ iv weekly

2)Cyclophosphamide $500 \mathrm{mg} / \mathrm{m} 2$ day 1

+ Epirubicin $60 \mathrm{mg} / \mathrm{m} 2$ iv day 1 of cycle

+ 5-Fluorouracil $500 \mathrm{mg} / \mathrm{m} 2$ iv day 1 next cycle day 22

Outcomes

Survival and TTP curves - Kaplan-Meier product limit method - from commencement of chemotherapy to death or last day of $\mathrm{F} / \mathrm{u}$
Median survival
1) $16 \mathrm{mths}$
2) $18 \mathrm{mths}$
Median TTP
1) $8 \mathrm{mths}$
2) $10 \mathrm{mths}$
$\mathrm{OR}(\mathrm{CR}+\mathrm{PR})$
1) $67 / 140$
2) $79 / 143$

Toxicity WHO 3-4

Nausea/vomiting

1) $18 / 151$

2) $50 / 149$

Alopecia

1) $18 / 151$

2) $105 / 149$

Leukopenia

1) $16 / 151$

2) $41 / 149$

Toxic death - NR 
Joensuu H 1998 (Continued)

QOL Rotterdam symptom checklist (RSCL) 285 patients.

Notes $\quad$ F/U survival and TTP min 3mths (based on cycles) - max 61mths (last event on the curve)

**ITT analysis but survival analysis was repeated after 9 patients were found to be ineligible

\section{Risk of bias}

\begin{tabular}{|c|c|c|}
\hline Bias & Authors' judgement & Support for judgement \\
\hline $\begin{array}{l}\text { Random sequence genera- } \\
\text { tion (selection bias) }\end{array}$ & Low risk & Randomisation by computer generated random digits \\
\hline $\begin{array}{l}\text { Allocation concealment } \\
\text { (selection bias) }\end{array}$ & Low risk & Centrally randomised \\
\hline $\begin{array}{l}\text { Incomplete outcome data } \\
\text { (attrition bias) } \\
\text { All outcomes }\end{array}$ & Low risk & $\begin{array}{l}\text { ITT analysis but survival analysis was repeated after } 9 \text { patients were found to } \\
\text { be ineligible with the results remaining essentially similar }\end{array}$ \\
\hline $\begin{array}{l}\text { Selective reporting (re- } \\
\text { porting bias) }\end{array}$ & Low risk & All expected outcomes reported \\
\hline
\end{tabular}

Mouridsen HT 1977

\section{Study characteristics}

\begin{tabular}{ll}
\hline Methods & RCT - stochastic array of numbers, closed envelope \\
Denmark - multi-centre & \\
& Baseline comparability not reported or discussed \\
\hline Participants & 55 consecutive women with histologically verified and measurable metastatic disease /post- \\
menopausal < $75 y$ rs with no prior chemotherapy \\
$100 \%$ MBC \\
$100 \%$ firstline \\
Randomised no: \\
1) $n=27$ (median age 61; 48-76) \\
2) $n=28$ (median age 62;44-70) \\
Assessable no: \\
1) $n=24$ \\
2) $n=27$
\end{tabular}

C vs CMFVP
1) Cyclophosphamide $3 \mathrm{mg} / \mathrm{kg} /$ day
2) Cyclophosphamide $2 \mathrm{mg} / \mathrm{kg} /$ day oral
+ Vincristine $0.025 \mathrm{mg} / \mathrm{kg} \mathrm{IV}$, Methotrexate $0.75 \mathrm{mg} / \mathrm{kg} \mathrm{IV} \mathrm{+} \mathrm{5-Fluorouracil} 12 \mathrm{mg} / \mathrm{kg} \mathrm{IV} \mathrm{+} \mathrm{Prednisone}$
$0.75 \mathrm{mg} / \mathrm{kg}$ oral

Outcomes

\section{No survival or TTP curves}

$\mathrm{OR}(\mathrm{CR}+\mathrm{PR})$

1) $6 / 24$ (median duration of response 210 days)

2) $17 / 27$ (median duration of response 400 days) 
Mouridsen HT 1977 (Continued)

\section{Toxicity WHO3-4}

Leukopenia $<1000$ only reported in this review

1) $1 / 24$

2) $4 / 27$

Alopecia

1) $8 / 24$

2) $21 / 27$

Toxic deaths - Nil reported

Notes Poor quality print.

Not ITT - 4 patients died of (progressive disease) after randomisation and were not included in analysis

\section{Risk of bias}

\begin{tabular}{lll}
\hline Bias & Authors' judgement & Support for judgement \\
\hline $\begin{array}{l}\text { Random sequence genera- } \\
\text { tion (selection bias) }\end{array}$ & Low risk & Randomised using stochastic array of numbers \\
\hline $\begin{array}{l}\text { Allocation concealment } \\
\text { (selection bias) }\end{array}$ & High risk & Closed envelope - can be corrupted \\
\hline $\begin{array}{l}\text { Incomplete outcome data } \\
\text { (attrition bias) }\end{array}$ & Unclear risk & $\begin{array}{l}\text { Not ITT - 4 patients died of (progressive disease) after randomisation and were } \\
\text { not included in analysis }\end{array}$ \\
\hline $\begin{array}{l}\text { Selective reporting (re- } \\
\text { porting bias) }\end{array}$ & High risk & \begin{tabular}{l} 
Some expected outcomes not reported \\
\hline
\end{tabular}
\end{tabular}

Nabholtz JM 1999

\section{Study characteristics}

\begin{tabular}{ll}
\hline Methods & Accrual (July 1994 - February 1997) \\
RCT- Phase III & Randomisation centralised - block design by institution - no stratification by characteristics - non blind- \\
ed, \\
Canadian multicentre \\
Groups well balanced for pre-treatment characteristics \\
392 women over the age of 18 with histologically or cytologically proven metastatic progressive adeno- \\
carcinoma of the breast and measurable or non measurable but assessable disease \\
100\% MBC \\
38\% Firstline \\
All participants previously treated with anthrycycline CT for advanced disease or disease progression \\
within 12 months of the end of anthrycycline therapy given as adjuvant treatment. Excluded if pretreat- \\
ed with mitomycin, vinca alkaloids or taxoids \\
Randomised no: \\
1) $n=203$ (median age $51 ; 30-73)$ ) \\
2) 189 (median age 52;32-78)) \\
Assessable no:
\end{tabular}


Nabholtz JM 1999 (Continued)
1) $n=200$
2) $n=187$

\begin{tabular}{ll}
\hline Interventions & TXT vs MMC $+\mathrm{V} 2$ \\
& 1) Docetaxel $100 \mathrm{mg} / \mathrm{m} 2$ iv every 3 weeks \\
2) Mitomycin $12 \mathrm{mg} / \mathrm{m} 2$ iv every 6 wks \\
+ Vinblastine $6 \mathrm{mg} / \mathrm{m} 2$ iv every $3 \mathrm{wks}$ \\
Maximum 10 treatment cycles
\end{tabular}

Outcomes

Survival and TTP curves included - Kaplan-Meier method -

TTP from date of randomisation

TTF curve excluded

Median survival

1) $11.4 \mathrm{mths}$

2) $8.7 \mathrm{mths}$

Median TTP

1) 19 weeks

2) 11 weeks

$\mathrm{OR}(\mathrm{CR}+\mathrm{PR})$

1) $59 / 179$

2) $21 / 171$

Toxicity WHO 3-4

Nausea and vomiting

1) $14 / 200$

2) $9 / 187$

Neutropenia

1) $188 / 200$

2) $176 / 187$

Toxic death

1) $4 / 203$ (sepsis, pneumonia, unspecified infection, unexplained respiratory failure)

2) 3/189 (hemolytic uremia, progressive lymphangitic carcinomatosis)

QOL - EORTC QLQ-C30

ITT - 5 patients who did not receive treatment $(3 ; 2)$ were included in the efficacy analysis, including survival. Analysis of response and TTP was also done on eligible and assessable population

\section{Risk of bias}

\begin{tabular}{lll}
\hline Bias & Authors' judgement & Support for judgement \\
\hline $\begin{array}{l}\text { Random sequence genera- } \\
\text { tion (selection bias) }\end{array}$ & Low risk & Randomisation centralised using a block design by institution \\
\hline $\begin{array}{l}\text { Allocation concealment } \\
\text { (selection bias) }\end{array}$ & Low risk & Centrally randomised \\
\hline $\begin{array}{l}\text { Incomplete outcome data } \\
\text { (attrition bias) } \\
\text { All outcomes }\end{array}$ & Low risk & Missing data balanced across groups \\
\hline
\end{tabular}


Nabholtz JM 1999 (Continued)

Selective reporting (re- Low risk All expected outcomes reported porting bias)

Nielsen D 2000

\section{Study characteristics}

\begin{tabular}{|c|c|}
\hline Methods & $\begin{array}{l}\text { Accrual (July 1987-Nov 1990). } \\
\text { Phase III RCT. Consecutive patients were centrally registered and then randomised after stratification } \\
\text { by ECOG performance status } \\
\text { Denmark } \\
\text { Groups comparable on age, performance status, prior adjuvant therapy, menopausal status, sites and } \\
\text { number of metastatic sites, disease free interval to first recurrence and lead time from prior adjuvant } \\
\text { chemotherapy }\end{array}$ \\
\hline Participants & $\begin{array}{l}155 \text { women with histologically proven locally advanced or MBC and bidemensionally measurable dis- } \\
\text { ease } \\
92 \% \text { MBC } \\
100 \% \text { Firstline } \\
\text { Randomised no: } \\
\text { 1) } n=81 \text { (median age } 52 ; 34-68 \text { ) } \\
\text { 2) } n=74 \text { (median age } 55 ; 27-69) \\
\text { Assessable no: } \\
\text { 1) } n=74 \\
\text { 2) } n=65\end{array}$ \\
\hline Interventions & $\begin{array}{l}\text { E vs E+ CDDP } \\
\text { 1) Epirubicin } 70 \mathrm{mg} / \mathrm{m} 2 \text { days } 1 \text { and } 8 \text { every } 4 \text { weeks } \\
\text { 2) Epirubicin } 60 \mathrm{mg} / \mathrm{m} 2 \text { days } 1 \text { and } 8+ \\
\text { Cisplatin } 100 \mathrm{mg} / \mathrm{m} 2 \text { day } 1 \text { every } 4 \text { weeks }\end{array}$ \\
\hline Outcomes & $\begin{array}{l}\text { Survival and TTP curves - Kaplan Meier estimate. TTP calculated as time from first drug administration } \\
\text { Median survival } \\
\text { 1) } 15.1 \text { mths }(0.1-63.3) \\
\text { 2) } 21.5 \text { mths }(21.5(0.1-77.7) \\
\text { Median TTP } \\
\text { 1) } 8.4 \text { mths }(0.1-66.3) \\
\text { 2) } 15.3 \text { mths }(0.1-77.7) \\
\text { OR (CR+PR) } \\
\text { 1) } 45 / 74 \\
\text { 2) } 43 / 65 \\
\text { Toxicity WHO } 3-4 \\
\text { WCC } \\
\text { 1) } 59 / 74 \\
\text { 2) } 60 / 65 \\
\text { Toxic death } \\
\text { 1) } 2 \\
\text { 2) } 4\end{array}$ \\
\hline
\end{tabular}


Nielsen D 2000 (Continued)

Notes

FU survival and TTP min 1mth - max 77.7 mths based on text

ITT for response, survival and toxicity - although 10 declared ineligible, 6 refused treatment. No loss to follow up

\section{Risk of bias}

\begin{tabular}{|c|c|c|}
\hline Bias & Authors' judgement & Support for judgement \\
\hline $\begin{array}{l}\text { Random sequence genera- } \\
\text { tion (selection bias) }\end{array}$ & Unclear risk & Centrally randomised but method not described \\
\hline $\begin{array}{l}\text { Allocation concealment } \\
\text { (selection bias) }\end{array}$ & Low risk & Centrally randomised \\
\hline $\begin{array}{l}\text { Incomplete outcome data } \\
\text { (attrition bias) } \\
\text { All outcomes }\end{array}$ & Low risk & No missing outcome data \\
\hline $\begin{array}{l}\text { Selective reporting (re- } \\
\text { porting bias) }\end{array}$ & Low risk & All expected outcomes reported \\
\hline
\end{tabular}

Nielson D 1990

\section{Study characteristics}

\begin{tabular}{|c|c|}
\hline Methods & $\begin{array}{l}\text { Accrual (January } 1983 \text { - December 1986) } \\
\text { RCT- Consecutive patients were centrally registered and after stratification by performance status were } \\
\text { randomised? method not fully described } \\
\text { Denmark } \\
\text { Baseline comparability }\end{array}$ \\
\hline Participants & $\begin{array}{l}143 \text { women with histologically proven advanced progressive breast cancer with measurable or evalu- } \\
\text { able disease - prior adjuvant or CT for MBC } \\
\text { No prior anthracycline } \\
100 \% \text { MBC } \\
48 \% \text { First line } \\
\text { Randomised no: } \\
\text { 1) } n=76 \text { (median age } 56 ; 28-69 \text { ) - Oophorectomy in } 4 \text { pts } \\
\text { 2) } n=67 \text { (median age } 55 ; 33-70 \text { ) - Oophorectomy in } 6 \text { pts } \\
\text { Evaluable for response and toxicity: } \\
\text { 1) } n=72 \\
\text { 2) } n=61\end{array}$ \\
\hline Interventions & $\begin{array}{l}\text { Evs E+V4 } \\
\text { 1) Epirubicin } 60 \mathrm{mg} / \mathrm{m} 2 \text { iv days } 1 \& 8 \text { every } 4 \text { wks } \\
\text { 2) Epirubicin } 45 \mathrm{mg} / \mathrm{m} 2 \\
\text { + Vindesine } 3 \mathrm{mg} / \mathrm{m} 2 \text { iv day } 1 \& 8 \text { every } 4 \text { weeks }\end{array}$ \\
\hline Outcomes & $\begin{array}{l}\text { Survival and TTP curves - from randomisation - survival and TTP - Kaplan Meier estimates } \\
\text { Median survival } \\
\text { 1) } 12 \mathrm{mths} \\
\text { 2) } 12 \mathrm{mths}\end{array}$ \\
\hline
\end{tabular}


Nielson D 1990 (Continued)

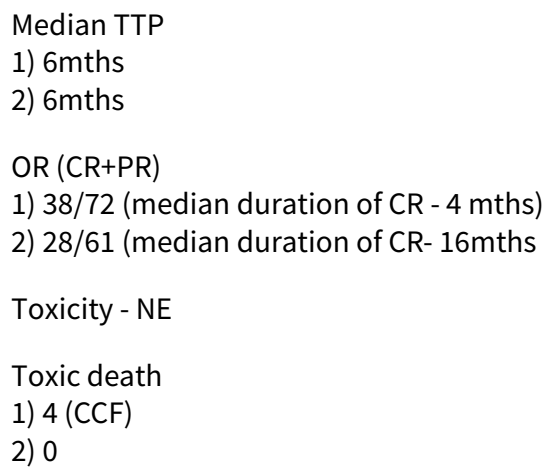

1) $6 \mathrm{mths}$

2) $6 \mathrm{mths}$

$\mathrm{OR}(\mathrm{CR}+\mathrm{PR})$

1) $38 / 72$ (median duration of CR - 4 mths)

2) $28 / 61$ (median duration of CR- $16 \mathrm{mths}$

Toxicity - NE

Toxic death

1) 4 (CCF)

2) 0

\begin{tabular}{ll}
\hline Notes & F/U survival min $0-80$ mths (stated in text \\
F/U TTP min 2mths - 36mths (Text and last event on the curve) \\
Appears ITT \\
\hline
\end{tabular}

\section{Risk of bias}

\section{Bias}

Authors' judgement Support for judgement

Random sequence genera- Unclear risk Centrally randomised but method not described tion (selection bias)

Allocation concealment Low risk $\quad$ Centrally randomised
(selection bias)

Incomplete outcome data Low risk No missing outcome data

(attrition bias)

All outcomes

Selective reporting (re- Low risk $\quad$ All expected outcomes reported
porting bias)

\section{Norris B 2000}

\section{Study characteristics}

\begin{tabular}{|c|c|}
\hline Methods & $\begin{array}{l}\text { Accrual (January } 1992 \text { - July 1995) } \\
\text { RCT - randomisation performed centrally at the NCIC CTG central office } \\
\text { Multi-centre (Canada), } \\
\text { Groups comparable at baseline for age, menstrual status and disease type }\end{array}$ \\
\hline Participants & $\begin{array}{l}303 \text { histologically proven and/or measurable metastatic breast cancer } \\
\text { Vinca alkaloid, anthracycline and mitoxantrone naïve } \\
100 \% \text { MBC } \\
75 \% \text { First line } \\
\text { Randomised no: } \\
\text { 1) } n=149 \\
\text { 2) } n=151 \\
\text { Assessable for response: } \\
\text { 1) } n=144 \\
\text { 2) } n=145\end{array}$ \\
\hline
\end{tabular}


Norris B 2000 (Continued)

Assessable for toxicity:

1) $n=149$

2) $n=151$

\begin{tabular}{|c|c|}
\hline Interventions & $\begin{array}{l}\text { A vs } A+V 3 \\
\text { 1) Doxorubicin } 70 \mathrm{mg} / \mathrm{m} 2 \text { day } 1 \text { every } 3 / 52 \\
\text { 2) Doxorubicin } 70 \mathrm{mg} / \mathrm{m} 2 \text { day } 1+ \\
\text { Vinorelbine } 25 \mathrm{mg} / \mathrm{m} 2 \text { days } 1 \text { and } 8 \text { every } 3 / 52 \\
\text { changed to } \\
\text { 1) Doxorubicin } 60 \mathrm{mg} / \mathrm{m} 2 \text { day } 1 \text { every } 3 / 52 \\
\text { 2) Doxorubicin } 40 \mathrm{mg} / \mathrm{m} 2 \text { day } 1+ \\
\text { Vinorelbine } 20 \mathrm{mg} / \mathrm{m} 2 \text { on days } 1 \text { and } 8 \text { every } 3 / 52\end{array}$ \\
\hline Outcomes & $\begin{array}{l}\text { Survival curve Kaplan-Meier. No TTP curve } \\
\text { Median survival } \\
\text { 1) } 14.4 \text { mths } \\
\text { 2) } 13.8 \text { mths } \\
\text { Median TTP } \\
\text { 1) } 6.1 \text { months } \\
\text { 2) Median } 6.2 \text { months } \\
\text { OR (CR+PR) } \\
\text { 1) } 44 / 144 \\
\text { 2) } 55145 \\
\text { Nausea and vomiting } \\
\text { 1) } 45 / 149 \\
\text { 2) } 29 / 151 \\
\text { Alopecia } \\
\text { 1) } 36 / 149 \\
\text { 2) } 33 / 151 \\
\text { Granulocytopenia } \\
\text { 1) } 129 / 149 \\
\text { 2) } 132 / 151 \\
\text { Toxic death } \\
\text { 1) } 2 / 149 \text { (cardiomyopathy, febrile neutropenia) } \\
\text { 2) } 1 / 151 \text { (febrile neutropenia) } \\
\text { Quality of life _EORTC QLQ-30 }\end{array}$ \\
\hline Notes & $\begin{array}{l}\text { F/U min } 1 \mathrm{mth}-\max 34 \mathrm{mths} \text { (based on curve). } \\
\text { No loss to F/U } \\
\star{ }^{\star} \text { Dosing changed in November } 1992 \text { following } 16 \text { of the first } 65 \text { patients experiencing febrile neutrope- } \\
\text { nia }\end{array}$ \\
\hline
\end{tabular}

\section{Risk of bias}

Bias Authors' judgement Support for judgement

Random sequence genera- Unclear risk $\quad$ Centrally randomised but method unclear
tion (selection bias)

\begin{tabular}{lll}
\hline $\begin{array}{l}\text { Allocation concealment } \\
\text { (selection bias) }\end{array}$ & Low risk & Centrally randomised
\end{tabular}


Norris B 2000 (Continued)

Incomplete outcome data Low risk No missing outcome data
(attrition bias)

All outcomes

Selective reporting (re- Low risk All expected outcomes reported
porting bias)

\section{O'Shaughnessy J 2001}

\section{Study characteristics}

\begin{tabular}{ll}
\hline Methods & Accrual (May 1996 - May 1997) \\
& RCT - randomised sequentially in a 1:2 ratio per country \\
& 23 international centres \\
& Well balanced at baseline \\
\hline Participants & 95 women with histologically proven advanced breast cancer not previously treated with cytotoxic \\
& therapy \\
$100 \%$ MBC \\
$100 \%$ Firstline \\
Randomised no: \\
1) $n=62$ \\
2) $n=33$
\end{tabular}

Interventions
CCB vs CMF
1) Capecitabine $1255 \mathrm{mg} / \mathrm{m} 2$ twice daily for two weeks followed by a 1 week rest period
2) Cyclophosphamide $600 \mathrm{mg} / \mathrm{m} 2+$
Methotrexate $40 \mathrm{mg} / \mathrm{m} 2+$
$5-F U 600 \mathrm{mg} / \mathrm{m} 2$ once every 3 weeks
Both regimens were conducted for up to 18 weeks

Survival and TTP curves
Median survival
1) 9.6 mths
2) 17.2 mths
Median TTP
1) 3.0 mths
2) 4.1 mths
OR (CR+PR)
1) $18 / 61$
2) $5 / 32$
Toxicity WHO 3-4
Nausea and vomiting
1) $7 / 61$
2) $3 / 32$
Neutropenia
1) $5 / 61$
2) $13 / 32$
Alopecia
1) $0 / 61$


O'Shaughnessy J 2001 (Continued)

\section{2) $1 / 32$}

Toxic death

1) 3

2) 0

Notes
F/U survival min 1mth - max $23 m$ ths (based on the curve)
F/U TTP min $1 \mathrm{mth}-12 \mathrm{mth}$ (based on the curve)
ITT used for all reported outcomes although 2 patients were removed following randomisation
Initial treatment period was 18 weeks. Patients with progressive disease were withdrawn from the
study

\section{Risk of bias}

\begin{tabular}{lll}
\hline Bias & Authors' judgement & Support for judgement \\
\hline $\begin{array}{l}\text { Random sequence genera- } \\
\text { tion (selection bias) }\end{array}$ & Unclear risk & States 'patients were randomised' \\
\hline $\begin{array}{l}\text { Allocation concealment } \\
\text { (selection bias) }\end{array}$ & Unclear risk & Not reported \\
\hline $\begin{array}{l}\text { Incomplete outcome data } \\
\begin{array}{l}\text { (attrition bias) } \\
\text { All outcomes }\end{array}\end{array}$ & Low risk & No missing outcome data \\
\hline $\begin{array}{l}\text { Selective reporting (re- } \\
\text { porting bias) }\end{array}$ & Low risk & All expected outcomes reported \\
\hline
\end{tabular}

O'Shaughnessy J 2002

\section{Study characteristics}

Methods

RCT - Phase III Multi-centre ( 75 centres, 16 countries)

Randomisation by country using a block size of four via a computer assisted, touch tone central randomisation service - Previous use of Paclitaxel was the only variable used for stratification

Baseline characteristics well balanced between the treatment groups

Participants
advanced and/or metastatic disease - at least one bi-dimensionally measurable lesion. All patients had
BC which recurred after anthracycline treatment. Ineligible if they had received docetaxel containing
regimens previously (paclitaxel OK)
$99 \%$ MBC
$66 \%$ First line
Randomised no:
1) 256 (Median age $51(25-75))$
2) 255 (Median age $52(26-79))$
Assessable for toxicity:
1) 255
2) 251

Interventions

\section{TXT vs TXT +CCB}

1) docetaxel $100 \mathrm{mg} / \mathrm{m} 2$ every 3 weeks 
O'Shaughnessy J 2002 (Continued)

2) capecitabine $1,250 \mathrm{mg} / \mathrm{m} 2$ twice daily on days $1-14+$

docetaxel $75 \mathrm{mg} / \mathrm{m} 2$

\begin{tabular}{|c|c|}
\hline Outcomes & $\begin{array}{l}\text { Survival and TTP curves - Kaplan-Meier } \\
\text { Median survival } \\
\text { 1) } 11.5 \text { mths } \\
\text { 2) } 14.5 \text { mths } \\
\text { Median TTP } \\
\text { 1) } 4.2 \text { mths } \\
\text { 2) } 6.1 \text { mths } \\
\text { Objective Response - best response } \\
\text { 1) } 77 / 256 \\
\text { 2) } 107 / 255 \\
\text { Toxicity WHO 3-4 } \\
\text { Nausea } \\
\text { 1) } 5 / 255 \\
\text { 2) } 15 / 251 \\
\text { Alopecia } \\
\text { 1) } 18 / 255 \\
\text { 2) } 15 / 251 \\
\text { Neutropenia } \\
\text { 1) } 38 / 255 \\
\text { 2) } 40 / 251 \\
\text { Toxic death } \\
\text { 1) } 1 \text { - neutropenic sepsis } \\
\text { 2) } 4 \text { - enterocolitis, sepsis, pulmonary oedema, hepatic coma } \\
\text { QOL - European organisation for research and treatment of cancer EORTC QLQ- C30 Global Health } \\
\text { Score } 230 \text { pts group } 1 ; 224 \text { group } 2 \\
\text { (1) }\end{array}$ \\
\hline Notes & $\begin{array}{l}\text { F/U survival min } 23 \text { mths (stated) - max } 44 \text { mths (last event on curve) } \\
\text { F/U TTP min } 23 \text { mths (stated) - max } 44 m \text { ths (last event on curve) } \\
\text { All efficacy data ITT - safety was assessed using pts who received at least one dose of study medication } \\
\text { and for whom follow up data was available }\end{array}$ \\
\hline
\end{tabular}

\section{Risk of bias}

\begin{tabular}{lll}
\hline Bias & Authors' judgement & Support for judgement \\
\hline $\begin{array}{l}\text { Random sequence genera- } \\
\text { tion (selection bias) }\end{array}$ & Low risk & $\begin{array}{l}\text { Randomisation by country using a block size of four via a computer assisted, } \\
\text { touch tone central randomisation service }\end{array}$ \\
\hline $\begin{array}{l}\text { Allocation concealment } \\
\text { (selection bias) }\end{array}$ & Low risk & Centrally randomised \\
\hline $\begin{array}{l}\text { Incomplete outcome data } \\
\text { (attrition bias) } \\
\text { All outcomes }\end{array}$ & Low risk & No missing outcome data \\
\hline $\begin{array}{l}\text { Selective reporting (re- } \\
\text { porting bias) }\end{array}$ & Low risk & All expected outcomes reported \\
\hline
\end{tabular}


Rubens RD 1975

\section{Study characteristics}

\begin{tabular}{ll}
\hline Methods & Accrual (June 1970- December 1974) \\
& RCT - no details of methodology provided \\
UK single centre \\
Groups comparable at baseline \\
\hline Participants & $\begin{array}{l}99 \text { women with advanced breast cancer, relapsed or failed on endocrine therapy } \\
100 \% \text { MBC } \\
100 \% \text { Firstline } \\
\text { Randomised no: } \\
\text { 1) } n=49 \\
\text { 2) } n=50\end{array}$ \\
\hline
\end{tabular}

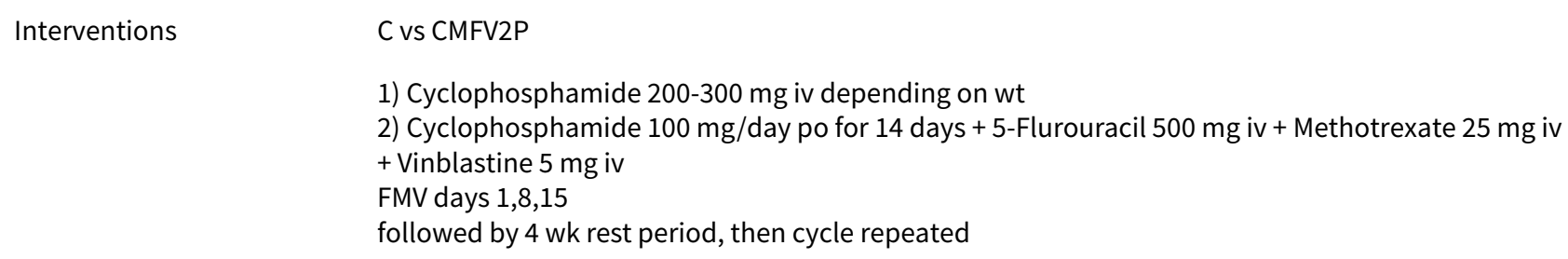

\section{Risk of bias}

\begin{tabular}{lll}
\hline Bias & Authors' judgement & Support for judgement \\
\hline $\begin{array}{l}\text { Random sequence genera- } \\
\text { tion (selection bias) }\end{array}$ & Unclear risk & Not reported \\
\hline $\begin{array}{l}\text { Allocation concealment } \\
\text { (selection bias) }\end{array}$ & Unclear risk & Not reported \\
\hline $\begin{array}{l}\text { Incomplete outcome data } \\
\text { (attrition bias) } \\
\text { All outcomes }\end{array}$ & Unclear risk & Insufficient information provided to permit judgement \\
\hline $\begin{array}{l}\text { Selective reporting (re- } \\
\text { porting bias) }\end{array}$ & Unclear risk & Insufficient information provided to permit judgement \\
\hline
\end{tabular}


Sjostrom J 1999

\section{Study characteristics}

\begin{tabular}{|c|c|}
\hline Methods & $\begin{array}{l}\text { Accrual (December } 1994 \text { - October 1997) } \\
\text { RCT - Phase III - method of randomisation not described } \\
\text { Scandinavia, Estonia and Poland - multi centre } \\
\text { Baseline comparability on patient characteristics }\end{array}$ \\
\hline Participants & $\begin{array}{l}283 \text { women with } 100 \% \text { MBC who had failed previous firstline anthracycline therapy or had failed previ- } \\
\text { ous adjuvant anthracycline therapy } \\
\text { First and second line } \\
\text { Randomised no: } \\
\text { 1) } 143 \text { (Median age } 50(27-69) \text { ) } \\
\text { 2) } 140 \text { (Median age } 51(26-59) \text { ) } \\
\text { Assessable for response: } \\
\text { 1) } n=143 \\
\text { 2) } n=139 \\
\text { Assessable for toxicity: } \\
\text { 1) } n=140 \\
\text { 2) } n=139 \\
3 \text { patients in the single agent arm did not receive treatment }\end{array}$ \\
\hline
\end{tabular}

Interventions

\section{TXT vs $M+F$}

1) Docetaxel $100 \mathrm{mg} / \mathrm{m} 2$ iv every $3 \mathrm{wks}$

2) Methotrexate $200 \mathrm{mg} / \mathrm{m} 2$ days $1 \& 8$ every $3 \mathrm{wks}$

+ 5-Fluorouracil $600 \mathrm{mg} / \mathrm{m} 2$ iv

days $1 \& 8$ every 3 wks

Outcomes

Survival and TTP curves (from date of randomisation)

Median survival

1) $10.4 \mathrm{mths}$

2) $11.0 \mathrm{mths}$

Median TTP

1) $6.3 \mathrm{mths}$

2) $3 \mathrm{mths}$

$\mathrm{OR}(\mathrm{CR}+\mathrm{PR})$

1) $61 / 143$

2) $29 / 139$

Toxicity WHO 3-4 (280 evaluable for haematological safety and 269 for haematological toxicity)

Nausea

1) $6 / 140$

2) $11 / 139$

Alopecia

1) $74 / 140$

2) $17 / 139$

WCC
1) $108 / 140$
2) $22 / 139$

Toxic death

1) 3 (2 febrile leucopenia and 1 generalised infected erythroderma) 
Sjostrom J 1999 (Continued)
2) 1 (febrile leucopenia)
QOL EORTC QLQ-C30

\begin{tabular}{|c|c|}
\hline Notes & $\begin{array}{l}\text { F/U survival and TTP min } 4 \mathrm{mths} \text { - max } 36 \mathrm{mths} \text { (stated in text) } \\
\text { ITT on all efficacy analysis } \\
\text { Crossover on progression recommended }\end{array}$ \\
\hline
\end{tabular}

\section{Risk of bias}

\begin{tabular}{lll}
\hline Bias & Authors' judgement & Support for judgement \\
\hline $\begin{array}{l}\text { Random sequence genera- } \\
\text { tion (selection bias) }\end{array}$ & Unclear risk & Not reported \\
\hline $\begin{array}{l}\text { Allocation concealment } \\
\text { (selection bias) }\end{array}$ & Unclear risk & Not reported \\
\hline $\begin{array}{l}\text { Incomplete outcome data } \\
\text { (attrition bias) } \\
\text { All outcomes }\end{array}$ & Low risk & No missing outcome data \\
\hline $\begin{array}{l}\text { Selective reporting (re- } \\
\text { porting bias) }\end{array}$ & Low risk & All expected outcomes reported \\
\hline
\end{tabular}

Sledge G(A) 2003

\section{Study characteristics}

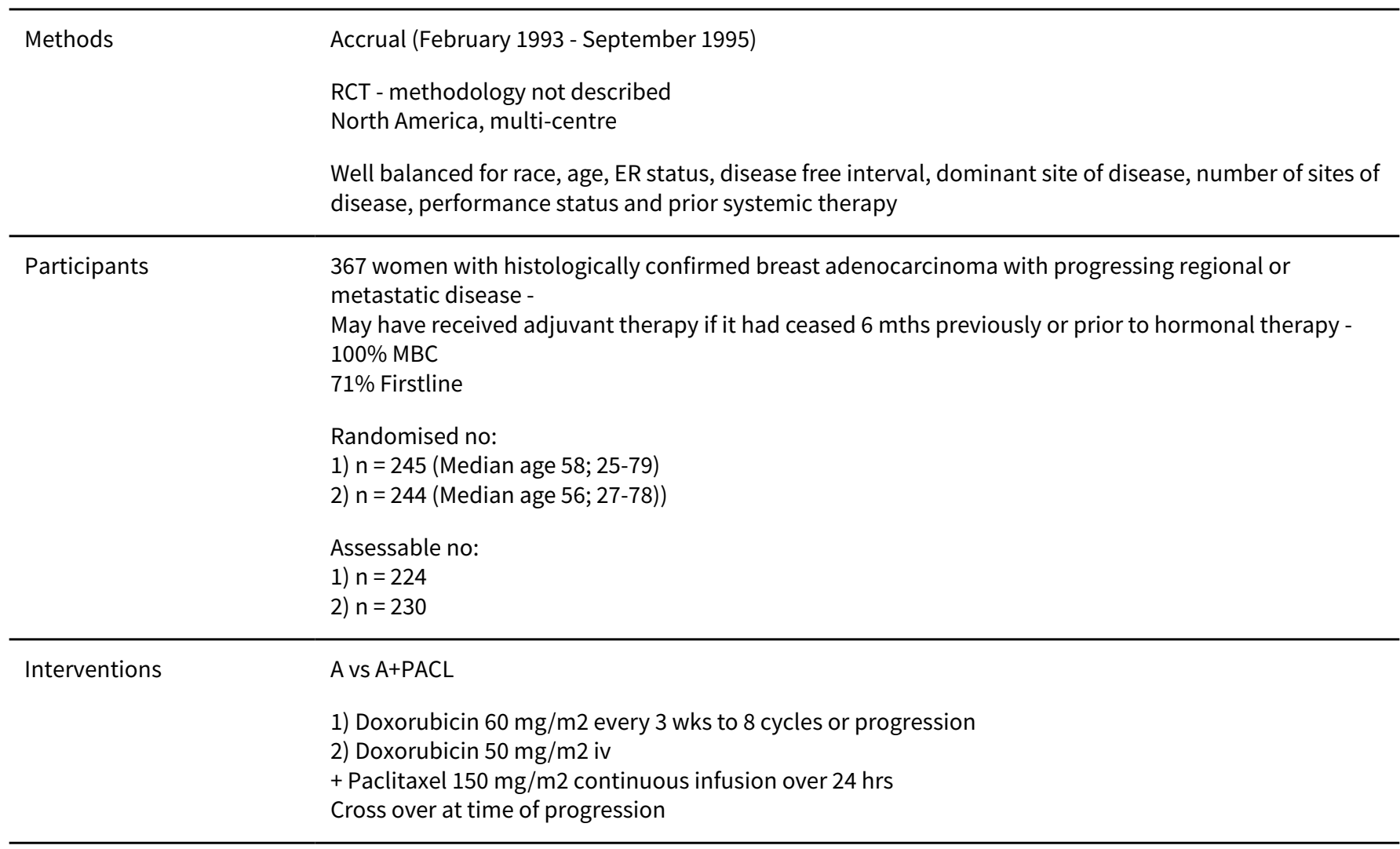


Sledge G(A) 2003 (Continued)

Outcomes
OS curves - log rank test. OS measured from date of study entry to death/date of progressive disease TTF curve. Excluded.

Median survival

1) $19.1 \mathrm{mths}$

2) $22.4 \mathrm{mths}$

Median TTF

1) $6 \mathrm{mths}$

2) $8.2 \mathrm{mths}$

Response (objective)

1) $81 / 224$

2) $108 / 230$

Toxicity Mod - Sev ( $\mathrm{NCl}$ criteria)

Leukopenia

1) $111 / 224$

2) $126 / 230$

Vomiting

1) $15 / 224$

2) $10 / 230$

Toxic death

1) $6 / 224$

2) $4 / 230$

QoL - Functional assessment of cancer therapy - breast (fact B) administered at baseline and 16 weeks

F/U survival and TTP min $6 \mathrm{mths}$ (based on maximum of eight cycles of 3 weeks) - max 75mths(last event on curve)

Not ITT - 739 patients were initially randomised - 731 total in trial based on group numbers provided in the text.

Text states 16 patients excluded and 33 pts excluded from the analysis for reasons of ineligibility

Excluded from firstline analysis

\section{Risk of bias}

\begin{tabular}{lll}
\hline Bias & Authors' judgement & Support for judgement \\
\hline $\begin{array}{l}\text { Random sequence genera- } \\
\text { tion (selection bias) }\end{array}$ & Unclear risk & Not reported \\
\hline
\end{tabular}

\begin{tabular}{ll}
\hline $\begin{array}{l}\text { Allocation concealment } \\
\text { (selection bias) }\end{array}$ & Unclear risk
\end{tabular}

Incomplete outcome data Unclear risk Insufficient reporting to permit judgement
(attrition bias)

All outcomes

Selective reporting (re- Low risk All expected outcomes reported
porting bias)


Sledge G(B) 2003

\section{Study characteristics}

\begin{tabular}{|c|c|}
\hline Methods & $\begin{array}{l}\text { Accrual (February } 1993 \text { - September 1995) } \\
\text { RCT - methodology not described } \\
\text { North America, multi-centre } \\
\text { Well balanced for race, age, ER status, disease free interval, dominant site of disease, number of sites of } \\
\text { disease, performance status and prior systemic therapy }\end{array}$ \\
\hline Participants & $\begin{array}{l}364 \text { women with histologically confirmed breast adenocarcinoma with progressing regional or } \\
\text { metastatic disease - } \\
\text { May have received adjuvant therapy if it had ceased } 6 \text { mths previously or prior to hormonal therapy - } \\
100 \% \text { MBC } \\
71 \% \text { Firstline } \\
\text { Randomised no: } \\
\text { 1) } n=242 \text { (Median age } 56 ; 27-76 \text { ) } \\
\text { 2) } n=244 \text { (Median age } 56 ; 27-78) \text { ) } \\
\text { Assessable no: } \\
\text { 1) } n=229 \\
\text { 2) } n=230\end{array}$ \\
\hline
\end{tabular}

Interventions

\section{PACL vs A+PACL}

1) Paclitaxel $175 \mathrm{mg} / \mathrm{m} 2 / 24 \mathrm{hrs}$

2) Doxorubicin $50 \mathrm{mg} / \mathrm{m} 2$ iv

+ Paclitaxel $150 \mathrm{mg} / \mathrm{m} 2$ continuous infusion over $24 \mathrm{hrs}$

Cross over at time of progression

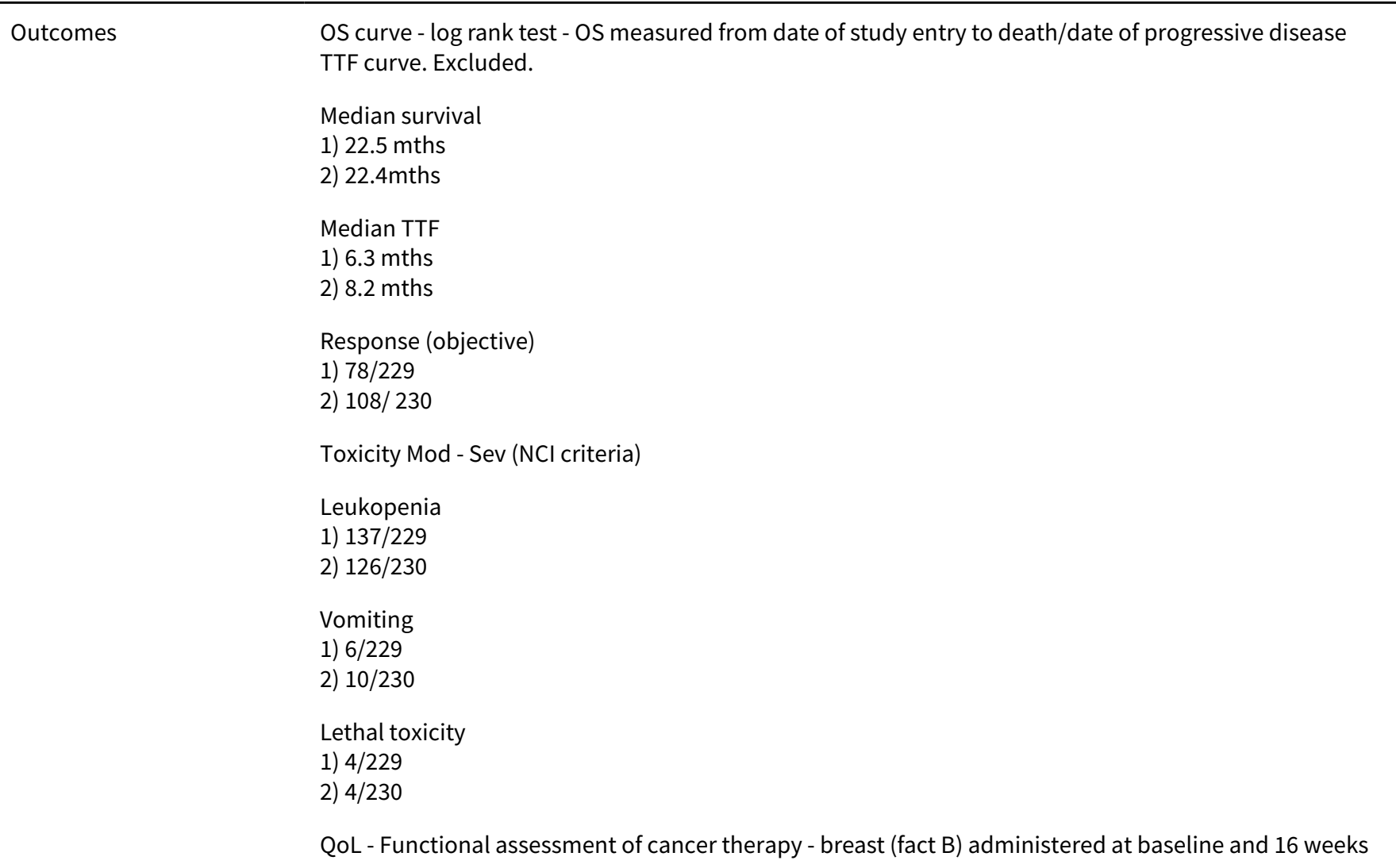


Sledge G(B) 2003 (Continued)

Notes
F/U survival and TTP min $6 \mathrm{mths}$ (based on maximum of eight cycles of 3 weeks) - max $75 \mathrm{mths}$ (last event on curve)

Not ITT - 739 patients were initially randomised - 731 total in trial based on group numbers provided in the text.

Text states 16 patients excluded and 33 pts excluded from the analysis for reasons of ineligibility

Excluded from firstline analysis

\section{Risk of bias}

\begin{tabular}{|c|c|c|}
\hline Bias & Authors' judgement & Support for judgement \\
\hline $\begin{array}{l}\text { Random sequence genera- } \\
\text { tion (selection bias) }\end{array}$ & Unclear risk & Not reported \\
\hline $\begin{array}{l}\text { Allocation concealment } \\
\text { (selection bias) }\end{array}$ & Unclear risk & Not reported \\
\hline $\begin{array}{l}\text { Incomplete outcome data } \\
\text { (attrition bias) } \\
\text { All outcomes }\end{array}$ & Unclear risk & Insufficient reporting to permit judgement \\
\hline $\begin{array}{l}\text { Selective reporting (re- } \\
\text { porting bias) }\end{array}$ & Low risk & All expected outcomes reported \\
\hline
\end{tabular}

Steiner R 1983

\section{Study characteristics}

\begin{tabular}{|c|c|}
\hline \multirow[t]{2}{*}{ Methods } & $\begin{array}{l}\text { Accrual (May } 1977 \text { - Jan 1980) } \\
\text { RCT - methodology not described }\end{array}$ \\
\hline & $\begin{array}{l}\text { Groups at baseline similar in age and diagnosis, post operative disease free interval and time interval } \\
\text { between diagnosis and commencement of treatment. Performance status more favourable in combi- } \\
\text { nation group }\end{array}$ \\
\hline
\end{tabular}

\begin{tabular}{|c|c|}
\hline \multirow[t]{3}{*}{ Participants } & $\begin{array}{l}119 \text { women with } M B C \text { with no prior chemotherapy for } A B C \text {, no signs of cardiac failure and the presence } \\
\text { of progressive disease in evaluable lesions } \\
116 \text { patients had previous endocrine therapy } \\
100 \% \text { MBC } \\
100 \% \text { firstline }\end{array}$ \\
\hline & Randomised numbers not provided \\
\hline & $\begin{array}{l}\text { Assessable no: } \\
\text { 1) } n=53 \\
\text { 2) } n=54\end{array}$ \\
\hline \multirow[t]{4}{*}{ Interventions } & $A$ vs $A+V 1$ \\
\hline & 1) Doxorubicin $70 \mathrm{mg} / \mathrm{m} 2 \mathrm{IV}$ on day 1 of a $3 / 52$ cycle \\
\hline & 2) Doxorubicin $70 \mathrm{mg} / \mathrm{m} 2 \mathrm{IV}$ on day 1 of a $3 / 52$ cycle + Vincristine $1.4 \mathrm{mg} / \mathrm{m} 2$ (max $2 \mathrm{mg}$ ) on days 1 and 8 \\
\hline & ${ }^{\star *}$ Maximum of 8 courses \\
\hline Outcomes & $\begin{array}{l}\text { No survival curves. Survival curves for responders only } \\
\text { No TTP curves }\end{array}$ \\
\hline
\end{tabular}


Steiner R 1983 (Continued)
Median survival
1) $10 \mathrm{mths}$
2) $14 \mathrm{mths}$
$\mathrm{OR}(\mathrm{CR}+\mathrm{PR})$
1) $30 / 53$
2) $28 / 54$
Toxicity:
Nausea and vomiting
1) $42 / 53$
2) $47 / 54$
Alopecia
1) $44 / 53$
2) $47 / 54$
WCC
1) $3 / 53$
2) $10 / 54$
Toxic death
1) $1 / 53$ (septicaemia)
2) $1 / 54$ (pantocytopenia)

Notes ITT -
119 women were entered into the study but 10 were excluded from the analysis. A further 2 women
who died soon after randomisation were included in the survival analysis but not in the response analy-
sis.

\section{Risk of bias}

\begin{tabular}{lll}
\hline Bias & Authors' judgement & Support for judgement \\
\hline $\begin{array}{l}\text { Random sequence genera- } \\
\text { tion (selection bias) }\end{array}$ & Unclear risk & Not reported \\
\hline $\begin{array}{l}\text { Allocation concealment } \\
\text { (selection bias) }\end{array}$ & Unclear risk & Not reported \\
\hline $\begin{array}{l}\text { Incomplete outcome data } \\
\begin{array}{l}\text { (attrition bias) } \\
\text { All outcomes }\end{array}\end{array}$ & Unclear risk & $\begin{array}{l}\text { Randomisation numbers not provided and insufficient information provided } \\
\text { to permit judgement }\end{array}$ \\
\hline $\begin{array}{l}\text { Selective reporting (re- } \\
\text { porting bias) }\end{array}$ & High risk & Provides survival information for responders only \\
\hline
\end{tabular}

Stockler M 2006

\section{Study characteristics}

\begin{tabular}{ll}
\hline Methods & Accrual dates not stated \\
RCT, multi-centre, international & Randomisation not described in abstract \\
Well balanced at randomisation & \\
\hline Participants & 323 women with advanced breast cancer \\
\hline Single agent versus combination chemotherapy for metastatic breast cancer (Review)
\end{tabular}

Single agent versus combination chemotherapy for metastatic breast cancer (Review) 
Stockler M 2006 (Continued)

$100 \% \mathrm{MBC}$

$100 \%$ Firstline

Randomised no:

1) 214

2) 109

Interventions
CCB (intermittent/continuous) vs CMF
1) Capecitabine $2000 \mathrm{mg} / \mathrm{m} 2$ days $1-14$, rest day $15-21 \mathrm{OR}$
capecitabine $200 \mathrm{mg} / \mathrm{m} 2$ days $1-21$
2) Cyclophosphamide (dose not stated) days $1-14+$
Methotrexate (dose not stated) days 1 and $8+$
5-FU (dose not stated) days 1 and 8

Outcomes

Survival and PFS curves

Median survival

1) $22 \mathrm{mths}$

2) 18 months

Median PFS

1) $6 \mathrm{mths}$

2) $7 \mathrm{mths}$

$\mathrm{OR}(\mathrm{CR}+\mathrm{PR})$

1) $42 / 214$

2) $18 / 109$

Toxicity WHO 3-4

Neutropenia

1) $3 / 214$

2) $24 / 109$

Nausea and vomiting

1) $12 / 214$

2) $4 / 109$

Alopecia

1) $1 / 214$

2) $2 / 109$

Toxic death - NR

Notes

F/U survival and PFS min 1mth and max 33mths (based on curve)

Results calculated from poster presentation only as full paper not yet available

CCB arms combined to achieve OS, toxicity and response data

\section{Risk of bias}

\begin{tabular}{lll}
\hline Bias & Authors' judgement & Support for judgement \\
\hline $\begin{array}{l}\text { Random sequence genera- } \\
\text { tion (selection bias) }\end{array}$ & Unclear risk & Not reported \\
\hline $\begin{array}{l}\text { Allocation concealment } \\
\text { (selection bias) }\end{array}$ & Unclear risk & Not reported \\
\hline
\end{tabular}

Incomplete outcome data Low risk (attrition bias)

No missing outcome data 
Stockler M 2006 (Continued)

All outcomes

Selective reporting (re- Low risk All expected outcomes reported
porting bias)

\section{Takayama T(A) 2000}

\section{Study characteristics}

\begin{tabular}{|c|c|}
\hline Methods & $\begin{array}{l}\text { Accrual (March } 1990 \text { - September 1997). } \\
\text { Japan } \\
\text { RCT - Double blind randomised comparative study - can't determine methodology }\end{array}$ \\
\hline Participants & $\begin{array}{l}111 \text { women with advanced breast cancer } \\
100 \% \text { MBC } \\
? 100 \% \text { Firstline } \\
\text { Randomised numbers not provided. } \\
\text { Assessable no: } \\
\text { 1) } n=57 \\
\text { 2) } n=54\end{array}$ \\
\hline Interventions & $\begin{array}{l}\text { F vs F+C } \\
\text { 1) } 5 \text { Fluorouracil } 300 \mathrm{mg} / \text { day orally } \\
\text { 2) } 5 \text { Fluorouracil } 300 \mathrm{mg} / \text { day orally + } \\
\text { Cyclophosphamide } 150 \mathrm{mg} / \text { day }\end{array}$ \\
\hline Outcomes & $\begin{array}{l}\text { Survival and PFS curve included - can't determine method } \\
\text { OR (CR+PR) } \\
\text { 1) } 8 / 57 \\
\text { 2) } 20 / 54 \\
\text { Toxicity WHO } 3-4 \\
\text { Nausea and vomiting } \\
\text { 1) } 1 / 57 \\
\text { 2) } 0 / 54 \\
\text { WCC } \\
\text { 1) } 0 / 57 \\
\text { 2) } 24 / 54\end{array}$ \\
\hline
\end{tabular}

Notes

F/U survival min 5 mths - max 60 mths (based on curve)

F/U PFS min $1 \mathrm{mth}$ - max $24 \mathrm{mths}$ max

(based on curve)

Not ITT - 181 pts entered the trial but only 166 described

** Japanese - some included tables in English - limited information

** some information has been Interpreted by a Japanese speaking person

Abstract suggests $100 \%$ firstline but unclear in table of patient characteristics so excluded from firstline analysis

\section{Risk of bias}


Takayama T(A) 2000 (Continued)

\begin{tabular}{|c|c|c|}
\hline Bias & Authors' judgement & Support for judgement \\
\hline $\begin{array}{l}\text { Random sequence genera- } \\
\text { tion (selection bias) }\end{array}$ & Unclear risk & Not repoted \\
\hline $\begin{array}{l}\text { Allocation concealment } \\
\text { (selection bias) }\end{array}$ & Unclear risk & Not reported \\
\hline $\begin{array}{l}\text { Incomplete outcome data } \\
\text { (attrition bias) } \\
\text { All outcomes }\end{array}$ & Unclear risk & Some missing data but insufficient information provided to permit judgement \\
\hline $\begin{array}{l}\text { Selective reporting (re- } \\
\text { porting bias) }\end{array}$ & Low risk & All expected outcomes reported \\
\hline
\end{tabular}

\section{Takayama T(B) 2000}

\section{Study characteristics}

\begin{tabular}{|c|c|}
\hline Methods & $\begin{array}{l}\text { Accrual (March } 1990 \text { - September 1997). } \\
\text { Japan } \\
\text { RCT - Double blind randomised comparative study - can't determine methodology }\end{array}$ \\
\hline \multirow[t]{3}{*}{ Participants } & $\begin{array}{l}109 \text { women with advanced breast cancer } \\
100 \% \mathrm{MBC} \\
? 100 \% \text { Firstline }\end{array}$ \\
\hline & Randomised numbers not provided \\
\hline & $\begin{array}{l}\text { Assessable no: } \\
\text { 1) } n=55 \\
\text { 2) } n=54\end{array}$ \\
\hline \multirow[t]{2}{*}{ Interventions } & C vs F+C \\
\hline & $\begin{array}{l}\text { 1) Cyclophosphamide } 150 \mathrm{mg} / \text { day } \\
\text { 2) } 5 \text { Fluorouracil } 300 \mathrm{mg} / \text { day orally + } \\
\text { Cyclophosphamide } 150 \mathrm{mg} / \text { day }\end{array}$ \\
\hline \multirow[t]{12}{*}{ Outcomes } & Survival and PFS curve included - can't determine method \\
\hline & Response \\
\hline & 1) $13 / 55$ \\
\hline & 2) $20 / 54$ \\
\hline & Toxicity (3-4) \\
\hline & Nausea and vomiting \\
\hline & 1) $0 / 55$ \\
\hline & 2) $0 / 54)$ \\
\hline & WCC \\
\hline & 1) $24 / 55$ \\
\hline & 2) $24 / 54$ \\
\hline & Toxic death - NR \\
\hline Notes & F/U survival min 5 mths - max 60 mths (based on curve) \\
\hline
\end{tabular}


Takayama T(B) 2000 (Continued)

F/U PFS min 1mth - max 24mths max

(based on curve)

Not ITT - 181 pts entered the trial but only 166 described

** Japanese - some included tables in English - limited information

** Some information has been interpreted by a Japanese speaking person

Abstract suggests $100 \%$ firstline but unclear in table of patient characteristics so excluded from firstline analysis

\section{Risk of bias}

\begin{tabular}{lll}
\hline Bias & Authors' judgement & Support for judgement \\
\hline $\begin{array}{l}\text { Random sequence genera- } \\
\text { tion (selection bias) }\end{array}$ & Unclear risk & Not reported \\
\hline $\begin{array}{l}\text { Allocation concealment } \\
\text { (selection bias) }\end{array}$ & Unclear risk & Not reported \\
\hline $\begin{array}{l}\text { Incomplete outcome data } \\
\text { (attrition bias) } \\
\text { All outcomes }\end{array}$ & Unclear risk & Some missing data but insufficient information provided to permit judgement \\
\hline $\begin{array}{l}\text { Selective reporting (re- } \\
\text { porting bias) }\end{array}$ & Low risk & All expected outcomes reported \\
\hline
\end{tabular}

Tashiro H 1994

\section{Study characteristics}

Methods
Accrual (November 1986 - November 1989).
RCT - Randomisation using a table of random sampling numbers was controlled by the head of the hos-
pitals pharmacy department. Double Blind
Japan - single centre
Groups comparable at baseline
$\begin{aligned} & 60 \text { women with progressive advanced or metastatic breast cancer which can be measured or evaluated } \\ & \text { pre- and postmenopausal } \\ & 100 \% \text { MBC } \\ & 86 \% \text { Firstline } \\ & \text { Randomised no: } \\ & \text { 1) } 30 \text { (mean age 56.5) } \\ & \text { 2) } 30 \text { (mean age 55.4) } \\ & \text { Assessable no: } \\ & \text { 1) } n=28 \\ & \text { 2) } n=28\end{aligned}$

Interventions

FT vs UFT + placebo

1) 5 Fluoro-1-(tetrahydro - 2 furyl)- uracil (an analogue of $5 \mathrm{FU}) 800 \mathrm{mg} /$ day (Tegafur)

2) Tegafur $400 \mathrm{mg} /$ day

+ Uracil $896 \mathrm{mg} /$ day taken as 2 capsules 
Tashiro H 1994 (Continued)

$+2 \times$ placebo single agent capsules orally $2 x$ day

Outcomes Survival curve - Kaplan-Meier method - calculated from the commencement of chemo No TTP

Median survival

1) $34 \mathrm{mths}$

2) $47 \mathrm{mths}$

$\mathrm{OR}(\mathrm{CR}+\mathrm{PR})$

1) $6 / 28$

2) $11 / 28$

Toxicity WHO 3-4

Alopecia

1) $0 / 28$

2) $0 / 28$

WCC

1) $0 / 28$

2) $0 / 28$

Nausea and vomiting

1) $0 / 28$

2) $0 / 28$

Toxic death - NR

Notes F/U survival and TTP min 20mths - max 62mths (stated in text)

ITT including 3 group 2 patients who died between randomisation and start of treatment

Excluded from firstline analysis

\section{Risk of bias}

\begin{tabular}{lll}
\hline Bias & Authors' judgement & Support for judgement \\
\hline $\begin{array}{l}\text { Random sequence genera- } \\
\text { tion (selection bias) }\end{array}$ & Low risk & Randomisation using a table of random sampling numbers \\
\hline $\begin{array}{l}\text { Allocation concealment } \\
\text { (selection bias) }\end{array}$ & Unclear risk & Not reported \\
\hline $\begin{array}{l}\text { Incomplete outcome data } \\
\text { (attrition bias) } \\
\text { All outcomes }\end{array}$ & Unclear risk & No missing outcome data \\
\hline $\begin{array}{l}\text { Selective reporting (re- } \\
\text { porting bias) }\end{array}$ & Low risk & All expected outcomes reported \\
\hline
\end{tabular}

Thomas E 2008

\section{Study characteristics}

\begin{tabular}{ll}
\hline Methods & Accrual September 2003 - January 2006 \\
Multi centre - 22 countries \\
RCT - randomisation method not described \\
Baseline comparability
\end{tabular}


Thomas E 2008 (Continued)

Participants
752 women with measurable locally advanced or MBC pre-treated with or resistant to anthracyclines and taxanes

At least $85 \%$ MBC

$8 \%$ Firstline

Randomised no:

1) $n=377$

2) $n=375$

Assessable no:

1) $n=368$

2) $n=369$

Interventions
CCB versus CCB $+\mathrm{IX}$
1) Capecitabine $2500 \mathrm{mg} / \mathrm{m} 2$ oral, 2 divided doses days $1-14$
2) Capecitabine $2000 \mathrm{mg} / \mathrm{m} 2$ oral in two divided doses each day days $1-14+\mid \mathrm{xabepilone} 40 \mathrm{mg} / \mathrm{m} 23 \mathrm{hr}$
IV infusion on day 1
21 day cycle

Outcomes

PFS curve estimated by Kaplan-Meier method and compared using log rank test No OS curve but survival analysis planned once 631 patients have died

Median PFS

1) 4.2 months (3.81-4.5)

2) 5.8 months (5.45-6.97)

$\mathrm{OR}(\mathrm{CR}+\mathrm{PR})$

1) $54 / 377$

2) $130 / 375$

Toxicity (WHO 3/4)

Nausea/vomiting

1) $13 / 368$

2) $25 / 369$

Leukopenia

1) $21 / 368$

2) $210 / 369$

Alopecia

1) $3 / 368$

2) $27 / 369$

Toxic death

1) $n=3$ (neutropenia related)

2) $n=12$ (neutropenia related)

\section{Notes}

FU 1-25 months (estimated from curve)

ITT for PFS

\section{Risk of bias}

\begin{tabular}{lll}
\hline Bias & Authors' judgement & Support for judgement \\
\hline $\begin{array}{l}\text { Random sequence genera- } \\
\text { tion (selection bias) }\end{array}$ & Unclear risk & Not reported \\
\hline $\begin{array}{l}\text { Allocation concealment } \\
\text { (selection bias) }\end{array}$ & Unclear risk & Not reported \\
\hline
\end{tabular}


Thomas E 2008 (Continued)

Incomplete outcome data Low risk No missing outcome data
(attrition bias)

All outcomes

Selective reporting (re- Low risk $\quad$ All expected outcomes reported
porting bias)

\section{Vaughn CB 1988}

\section{Study characteristics}

RCT - Method not described Stratified as good or poor risk
North America - 22 member institutions of the South West Oncology Group
Baseline comparability for age, menopausal status, performance status, ER status and site of metasta-
sis
sis

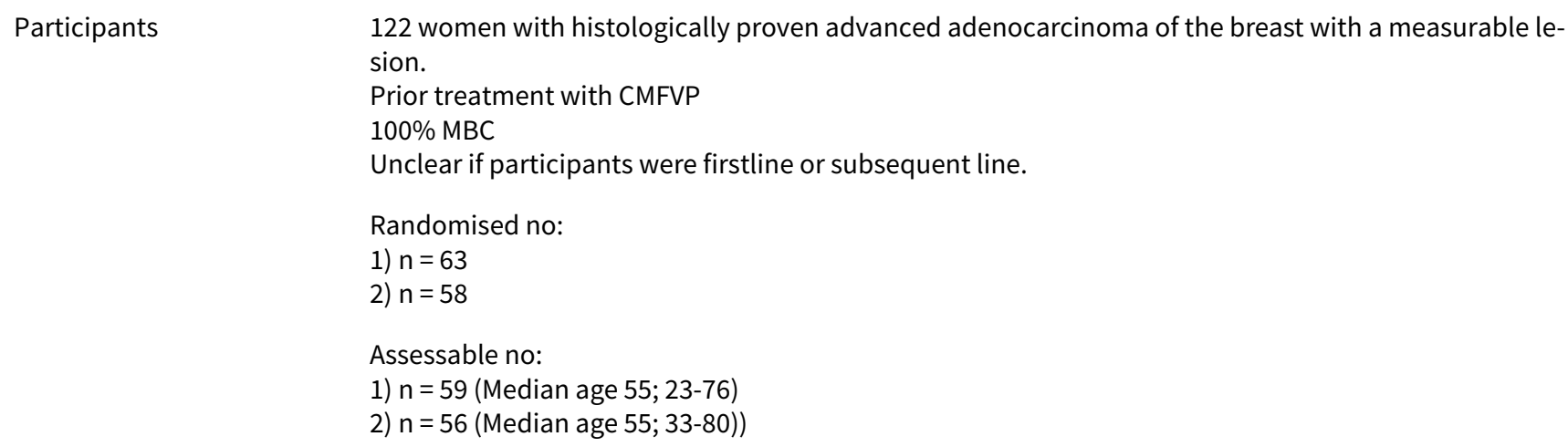

Interventions
A vs A+ETO
$\begin{aligned} & \text { 1) Doxorubicin } 60 \mathrm{mg} / \mathrm{m} 2 \text {, day } 1 \text { (good risk patients) or } 45 \mathrm{mg} / \mathrm{m} 2 \text {, day } 1 \text { (poor risk patients) } \\ & \text { 2) Doxorubicin } 35 \mathrm{mg} / \mathrm{m} 2 \text {, day } 1 \text { (good risk) or } 30 \mathrm{mg} / \mathrm{m} 2 \text {, day } 1 \text { (poor risk) } \\ & + \text { VP- } 1675 \mathrm{mg} / \mathrm{m} 2 / \text { day } 5 \text { days (good risk) or } 50 \mathrm{mg} / \mathrm{m} 2 / \text { day } \times 5 \text { days (poor risk) }\end{aligned}$

Outcomes Survival and TTP curves - estimated from date of randomisation

Median survival

1) $8.5 \mathrm{mths}$

2) $9.8 \mathrm{mths}$

Median TTP

1) $4.2 \mathrm{mths}$

2) $5.1 \mathrm{mths}$

OR (CR + PR)

1) $14 / 59$

2) $13 / 56$

Toxicity (SWOG criteria)
Alopecia
1) $57 / 59$
2) $57 / 56)$
Leukopenia
1) $16 / 59$ 
Vaughn CB 1988 (Continued)
2) $32 / 56$
Nausea and vomiting
1) $10 / 59$
2) $2 / 56$
Toxic death
1) 1 (cardiac toxicity)
2) 0

Notes

F/U survival min $1 \mathrm{mth}$ (one cycle) - max $66 \mathrm{mths}$ (last event on curve)

F/U TTP min 1mth (one cycle) - max 52mths (last event on curve)

Not ITT analysis - 7 ineligible patients excluded from the analysis (4 in group 1 and 3 in group 2).

Three pts with treatment deviations were excluded from toxicity tables but otherwise included in the arms they were randomised to. Nine and 8 patients respectively who discontinued treatment early were included in the analysis.

Excluded from firstline analysis

\begin{tabular}{lll}
\hline \multicolumn{1}{l}{ Risk of bias } & \\
\hline Bias & Authors' judgement & Support for judgement \\
\hline $\begin{array}{l}\text { Random sequence genera- } \\
\text { tion (selection bias) }\end{array}$ & Unclear risk & Not reported \\
\hline $\begin{array}{l}\text { Allocation concealment } \\
\text { (selection bias) }\end{array}$ & Unclear risk & Not reported \\
\hline $\begin{array}{l}\text { Incomplete outcome data } \\
\begin{array}{l}\text { (attrition bias) } \\
\text { All outcomes }\end{array}\end{array}$ & Low risk & Missing data equal across arms \\
\hline $\begin{array}{l}\text { Selective reporting (re- } \\
\text { porting bias) }\end{array}$ & Low risk & All expected outcomes reported \\
\hline
\end{tabular}

Venturino $A(A) 2000$

\section{Study characteristics}

\begin{tabular}{ll}
\hline Methods & RCT - Phase II - methodology not described \\
Italian - multi centre & \\
& Groups comparable \\
\hline Participants & 66 women with histopathologically confirmed diagnosis of breast cancer, progressive metastatic dis- \\
ease with assessable lesions and one previous chemotherapy for MBC & $100 \%$ MBC \\
& All second line \\
& Randomised no: \\
1) $n=33$ (median age $62.5 ; 34-74)$ \\
2) $n=33$ (median age 60;49-70)
\end{tabular}

\begin{tabular}{ll}
\hline Interventions & V3 vs LEUC+F \\
& 1) Vinorelbine $30 \mathrm{mg} / \mathrm{m} 2$ IV weekly \\
\hline
\end{tabular}


Venturino A(A) 2000 (Continued)

2) Leucovorin $100 \mathrm{mg} / \mathrm{m} 2$ IV + 5 Fluorouracil $370 \mathrm{mg} / \mathrm{m} 2$ IV

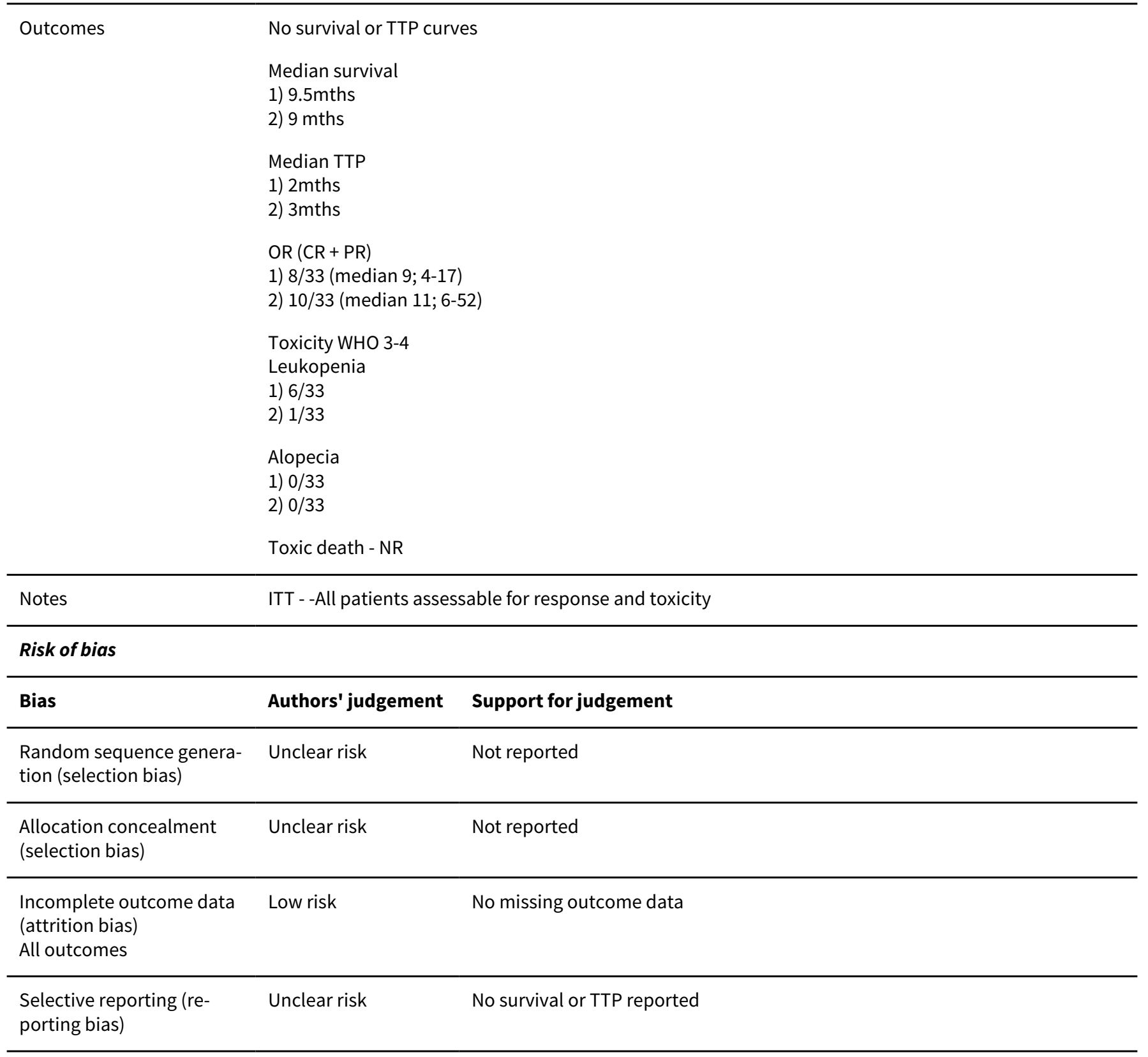

Venturino A (B) 2000

\section{Study characteristics}

Methods RCT - Phase II - methodology not described

Italian - multi centre

Groups comparable

\section{Participants}

66 women with histopathologically confirmed diagnosis of breast cancer, progressive metastatic disease with assessable lesions and one previous chemotherapy for MBC $100 \% \mathrm{MBC}$ 
Venturino A (B) 2000 (Continued)

$$
\begin{aligned}
& \text { All second line } \\
& \text { Randomised no: } \\
& \text { 1) } 33 \text { - median age } 62.5 \text { (34-74) } \\
& \text { 2) } 33 \text { median age } 60.5 \text { (41-71) } \\
& \text { Assessable no: } \\
& \text { 1) } 33 \\
& \text { 2) } 32 \text { - } 1 \text { lost at randomisation - }
\end{aligned}
$$

\begin{tabular}{|c|c|c|}
\hline Bias & Authors' judgement & Support for judgement \\
\hline $\begin{array}{l}\text { Random sequence genera- } \\
\text { tion (selection bias) }\end{array}$ & Unclear risk & Not reported \\
\hline $\begin{array}{l}\text { Allocation concealment } \\
\text { (selection bias) }\end{array}$ & Unclear risk & Not reported \\
\hline $\begin{array}{l}\text { Incomplete outcome data } \\
\text { (attrition bias) } \\
\text { All outcomes }\end{array}$ & Low risk & No missing outcome data \\
\hline $\begin{array}{l}\text { Selective reporting (re- } \\
\text { porting bias) }\end{array}$ & Unclear risk & No survival or TTP reported \\
\hline
\end{tabular}

Interventions
V3 vs MZA+LEUC+F
1) Vinorelbine $30 \mathrm{mg} / \mathrm{m} 2$ IV weekly
2) Mitoxantrone $12 \mathrm{mg} / \mathrm{m} 2$ IV day $1+$ Leucovorin $100 \mathrm{mg} / \mathrm{m} 2 \mathrm{IV}+5$ Fluorouracil $370 \mathrm{mg} / \mathrm{m} 2 \mathrm{IV}$

\begin{tabular}{ll}
\hline Outcomes & No survival or TTP curves \\
& Median survival \\
1) $9.5 \mathrm{mths}$ \\
2) 9 mths \\
Median TTP \\
1) 2 mths \\
2) 5 mths \\
OR (CR + PR) \\
1) $8 / 33$ (median 9; 4-17) \\
2) $7 / 32$ (median 10;5-33) \\
Toxicity WHO 3-4 \\
Leukopenia \\
1) $6 / 33$ \\
2) $1 / 32$ \\
Alopecia \\
1) $0 / 33$ \\
2) $0 / 32$ \\
Toxic deaths - nil reported
\end{tabular}

Notes ITT - -All but one patient from arm 2 assessable for response and toxicity

\section{Risk of bias}


Characteristics of excluded studies [ordered by study ID]

\begin{tabular}{|c|c|}
\hline Study & Reason for exclusion \\
\hline Anonymous 2002 & Listed in review (2005) in ongoing studies. Data unavailable and status of trial unknown \\
\hline Doroshow 1997 & $\begin{array}{l}\text { Listed in review (2005) in ongoing studies. No longer registered as ongoing on } \mathrm{NCl} \text { registry and no } \\
\text { data available. }\end{array}$ \\
\hline Jackisch C 1999 & $\begin{array}{l}\text { Listed in review (2005) in ongoing studies. Excluded due to allowance of participants to have up to } \\
6 \text { treatment cycles of induction chemotherapy prior to enrolment. }\end{array}$ \\
\hline Kaufman PA 1998 & Randomised numbers not available. Author did not respond to request for additional data. \\
\hline Keller AM 2004 & $\begin{array}{l}\text { Was included in initial review based on data obtained from ASCO } 2001 \text { conference proceeding (Ab- } \\
\text { stact number 115). Removed from review following review of full published paper (2004) which fur- } \\
\text { ther clarified the regimes studied. Of the } 151 \text { participants in the control arm } 129 \text { were receiving sin- } \\
\text { gle agent vinorelbine and } 22 \text { received mitomycin C plus vinblastine. Data was not provided sepa- } \\
\text { rately for combination and single agent regimens within the control group. }\end{array}$ \\
\hline Legha, 1979 & $\begin{array}{l}\text { Response data on one arm only available. Also patients found to be intolerant of treatment were } \\
\text { excluded from the analysis. Limited toxicity data available. }\end{array}$ \\
\hline Liu T 1986 & $\begin{array}{l}\text { Was included in the initial review but excluded based on a post hoc consideration of the decision } \\
\text { not to include high dose chemotherapy regimens. }\end{array}$ \\
\hline Mann GB 1985 & $\begin{array}{l}\text { Not all outcomes for the review available. Study includes small numbers and authors report a num- } \\
\text { ber of protocol violations. }\end{array}$ \\
\hline Nemoto T. 1978 & $\begin{array}{l}\text { Randomised numbers not available. Sequential. Toxicity and response data is provided for all se- } \\
\text { quences and is not extractable for sequence of interest. }\end{array}$ \\
\hline Perez E 2001 & $\begin{array}{l}\text { Listed in review (2005) in ongoing studies. Trial is listed on NCI registry as closed - author was con- } \\
\text { tacted but did not know of this trial. Trial registry informed. }\end{array}$ \\
\hline
\end{tabular}

Characteristics of ongoing studies [ordered by study ID]

\section{Burzynski 1999}

Study name
BRI-BR-10

Phase II Randomised Study of Methotrexate with or without Antineoplaston A10 Capsules in Women with Advanced Breast Cancer

\section{Methods}

\begin{tabular}{ll}
\hline Participants & $30-70$ patients with metastatic BC \\
North America \\
single-centre \\
$100 \%$ firstline \\
ER -ive \\
Postmenopausal
\end{tabular}

\footnotetext{
Interventions
}

Methotrexate po 5 days on $/ 5$ days off

vs Methotrexate po 5 days on/ 5 days off

+ Antineoplaston A10, 7 times daily until max tolerated dose reached

Outcomes Response


Burzynski 1999 (Continued)

$$
\text { Toxicity }
$$

\begin{tabular}{ll}
\hline Starting date & Not known \\
\hline Contact information & Principal Investigator: \\
& Dr Stanislaw Burzynski, \\
& Burzynski Research Institute, \\
& Houston, Texas, \\
& USA \\
& Phone: 713-597-0111 \\
\hline
\end{tabular}

Notes

\section{Butler FO 2004}

$\begin{array}{ll}\text { Study name } & \begin{array}{l}\text { A study of Docetaxel monotherapy or DOXIL/CAELYX and Doxetaxel in patients with advanced } \\ \text { breast cancer }\end{array}\end{array}$
breast cancer

\begin{tabular}{ll}
\hline Methods & \\
\hline Participants & $\begin{array}{l}\text { ? patients with advanced breast cancer } \\
>18 \text { years }\end{array}$ \\
\hline Interventions & Doxorubicin injection and docetaxel vs docetaxel alone \\
\hline Outcomes & Response \\
& $\begin{array}{l}\text { TTP } \\
\text { QOxicity }\end{array}$ \\
\hline Starting date & Not known \\
\hline Contact information & Principal Investigator: \\
& Fred Butler, Investigative Clinical Research, LLC, Indianapolis, Indiana, 46254, USA \\
\hline Notes & Identified in 2006 search for review update \\
\hline
\end{tabular}

\section{Heidemann E 2001}

\begin{tabular}{ll}
\hline Study name & $\begin{array}{l}\text { Phase III Randomised Study of Mitoxantrone vs CMF - Cyclophosphamide/Methotrexate/ } \\
\text { Fluorouracil }\end{array}$ \\
\hline Methods & \\
\hline Participants & 296 women \\
& $\begin{array}{l}35-80 y r s \\
\text { Pre and post menopausal } \\
\text { Histologically verified metastases } \\
100 \% \text { firstline }\end{array}$ \\
\hline Interventions & Mitoxantrone vs CMF \\
\hline Outcomes & Survival \\
\hline
\end{tabular}


Heidemann E 2001 (Continued)

QOL

TTP

Performance status

Response

\begin{tabular}{ll}
\hline Starting date & Not known \\
\hline Contact information & Hansjochen Wilke
\end{tabular}

\section{Notes}

Yunus F. 2000

\begin{tabular}{ll}
\hline Study name & $\begin{array}{l}\text { Phase III Randomised Study of Paclitaxel with or without Gemcitabine in Women with Unre- } \\
\text { sectable, Locally Recurrent, or Metastatic Breast Cancer }\end{array}$ \\
\hline Methods & $\begin{array}{l}\text { ? patients } \\
\text { Histologically or cytologically proven unresectable locally recurrent, or Metastatic Breast Cancer }\end{array}$ \\
\hline Participants & Paclitaxel vs Paclitaxel with or without Gemcitabine \\
\hline Interventions & Not known \\
\hline Outcomes & Not known \\
\hline Starting date & $\begin{array}{l}\text { Furhan Yunus } \\
\text { Eli Lilly and Company }\end{array}$ \\
\hline Contact information &
\end{tabular}

Notes

DATA AND ANALYSES

\section{Comparison 1. Overall survival}

\begin{tabular}{lllll}
\hline Outcome or subgroup title & No. of studies & $\begin{array}{l}\text { No. of partici- } \\
\text { pants }\end{array}$ & Statistical method & Effect size \\
\hline $\begin{array}{l}\text { 1.1 Overall survival - randomised patients } \\
\text { - all trials }\end{array}$ & 36 & 7147 & $\begin{array}{l}\text { Hazard Ratio (Exp[(O-E)/ } \\
\text { V], Fixed, 95\% Cl) }\end{array}$ & $0.88[0.83,0.93]$ \\
\hline $\begin{array}{l}1.1 .1 \text { Question 1: Regimen A (single) ver- } \\
\text { sus Regimen A + other }\end{array}$ & 25 & 4935 & Hazard Ratio (Exp[(O-E)/ & $0.88[0.83,0.94]$ \\
\hline $\begin{array}{l}1.1 .2 \text { Question 2: Regimen A (single) ver- } \\
\text { sus Regimen C (combination) }\end{array}$ & 11 & 2212 & Hazard Ratio (Exp[(O-E)/ & $0.86[0.78,0.96]$ \\
\hline $\begin{array}{l}1.2 \text { Overall survival - randomised patients } \\
\text { - first line }\end{array}$ & 21 & & V], Fixed, 95\% Cl) & Hazard Ratio (Exp[(O-E)/ \\
\hline
\end{tabular}




\begin{tabular}{|c|c|c|c|c|}
\hline Outcome or subgroup title & No. of studies & $\begin{array}{l}\text { No. of partici- } \\
\text { pants }\end{array}$ & Statistical method & Effect size \\
\hline $\begin{array}{l}\text { 1.2.1 Question 1: Regimen A (single) ver- } \\
\text { sus Regimen A + other }\end{array}$ & 14 & 2820 & $\begin{array}{l}\text { Hazard Ratio }(\operatorname{Exp}[(\mathrm{O}-\mathrm{E}) / \\
\text { V], Fixed, } 95 \% \mathrm{Cl})\end{array}$ & $0.88[0.80,0.96]$ \\
\hline $\begin{array}{l}\text { 1.2.2 Question 2: Regimen A (single) ver- } \\
\text { sus Regimen C (combination) }\end{array}$ & 7 & 1162 & $\begin{array}{l}\text { Hazard Ratio }(\operatorname{Exp}[(\mathrm{O}-\mathrm{E}) / \\
\text { V], Fixed, } 95 \% \mathrm{Cl})\end{array}$ & $0.87[0.75,1.01]$ \\
\hline $\begin{array}{l}1.3 \text { Overall survival - Question } 1 \text { - Regi- } \\
\text { men A versus A + other - randomised pa- } \\
\text { tients }\end{array}$ & 25 & 4935 & $\begin{array}{l}\text { Hazard Ratio }(\operatorname{Exp}[(\mathrm{O}-\mathrm{E}) / \\
\text { V], Fixed, } 95 \% \mathrm{Cl})\end{array}$ & $0.88[0.83,0.94]$ \\
\hline $\begin{array}{l}\text { 1.3.1 Sub group A: Single anthracycline } \\
\text { agent versus anthracycline + other regi- } \\
\text { men }\end{array}$ & 14 & 2897 & $\begin{array}{l}\text { Hazard Ratio }(\operatorname{Exp}[(\mathrm{O}-\mathrm{E}) / \\
\text { V], Fixed, } 95 \% \mathrm{Cl})\end{array}$ & $0.95[0.87,1.04]$ \\
\hline $\begin{array}{l}\text { 1.3.2 Sub group B: Single alkylating ver- } \\
\text { sus alkylating + other }\end{array}$ & 5 & 375 & $\begin{array}{l}\text { Hazard Ratio }(\operatorname{Exp}[(\mathrm{O}-\mathrm{E}) / \\
\text { V], Fixed, } 95 \% \mathrm{Cl})\end{array}$ & $0.91[0.72,1.15]$ \\
\hline $\begin{array}{l}\text { 1.3.3 Sub group C: Single antimetabolite } \\
\text { versus antimetabolite + other }\end{array}$ & 3 & 279 & $\begin{array}{l}\text { Hazard Ratio }(\operatorname{Exp}[(\mathrm{O}-\mathrm{E}) / \\
\text { V], Fixed, } 95 \% \mathrm{Cl})\end{array}$ & $0.62[0.46,0.82]$ \\
\hline $\begin{array}{l}\text { 1.3.4 Sub group D: Single taxane versus } \\
\text { taxane + other }\end{array}$ & 3 & 1384 & $\begin{array}{l}\text { Hazard Ratio }(\operatorname{Exp}[(\mathrm{O}-\mathrm{E}) / \\
\text { V], Fixed, } 95 \% \mathrm{Cl})\end{array}$ & $0.81[0.72,0.91]$ \\
\hline $\begin{array}{l}\text { 1.4 Overall survival - Question } 2 \text { - Regi- } \\
\text { men A versus Regimen C - randomised } \\
\text { patients }\end{array}$ & 10 & 1952 & $\begin{array}{l}\text { Hazard Ratio }(\operatorname{Exp}[(\mathrm{O}-\mathrm{E}) / \\
\text { V], Fixed, } 95 \% \mathrm{Cl})\end{array}$ & $0.87[0.78,0.97]$ \\
\hline $\begin{array}{l}\text { 1.4.1 Sub group E: Single anthracycline } \\
\text { agent versus non-anthracycline combina- } \\
\text { tion regimen }\end{array}$ & 2 & 88 & $\begin{array}{l}\text { Hazard Ratio }(\operatorname{Exp}[(\mathrm{O}-\mathrm{E}) / \\
\text { V], Fixed, } 95 \% \mathrm{Cl})\end{array}$ & $0.57[0.33,0.98]$ \\
\hline $\begin{array}{l}\text { 1.4.2 Sub group F: Single taxane versus } \\
\text { non-taxane, non-anthracycline contain- } \\
\text { ing combination regimen }\end{array}$ & 5 & 1262 & $\begin{array}{l}\text { Hazard Ratio }(\operatorname{Exp}[(\mathrm{O}-\mathrm{E}) / \\
\text { V], Fixed, } 95 \% \mathrm{Cl})\end{array}$ & $0.83[0.73,0.95]$ \\
\hline $\begin{array}{l}\text { 1.4.3 Sub group G: Single non-taxane, } \\
\text { non-anthracycline agent versus other } \\
\text { combination regimen }\end{array}$ & 3 & 602 & $\begin{array}{l}\text { Hazard Ratio }(\operatorname{Exp}[(\mathrm{O}-\mathrm{E}) / \\
\text { V], Fixed, } 95 \% \mathrm{Cl})\end{array}$ & $1.06[0.85,1.33]$ \\
\hline $\begin{array}{l}\text { 1.5 Overall survival - single agent taxane } \\
\text { versus all combination }\end{array}$ & 8 & 2646 & $\begin{array}{l}\text { Hazard Ratio }(\operatorname{Exp}[(\mathrm{O}-\mathrm{E}) / \\
\text { V], Fixed, } 95 \% \mathrm{Cl})\end{array}$ & $0.82[0.75,0.89]$ \\
\hline $\begin{array}{l}1.6 \text { Overall survival - single agent anthra- } \\
\text { cycline versus all combinations }\end{array}$ & 16 & 2985 & $\begin{array}{l}\text { Hazard Ratio }(\operatorname{Exp}[(\mathrm{O}-\mathrm{E}) / \\
\text { V], Fixed, } 95 \% \mathrm{Cl})\end{array}$ & $0.94[0.86,1.02]$ \\
\hline
\end{tabular}


Analysis 1.1. Comparison 1: Overall survival, Outcome 1: Overall survival - randomised patients - all trials

\begin{tabular}{|c|c|c|c|c|c|c|c|c|c|c|}
\hline Study or Subgroup & $\begin{array}{l}\text { Combir } \\
\text { Events }\end{array}$ & $\begin{array}{l}\text { ation } \\
\text { Total }\end{array}$ & Single agent & $\begin{array}{l}\text { gent } \\
\text { Total }\end{array}$ & O-E & Variance & Weight & $\begin{array}{c}\text { Hazard Ratio } \\
\text { Exp[(O-E) / V], Fixed, 95\% CI }\end{array}$ & \multicolumn{2}{|c|}{$\begin{array}{c}\text { Hazard Ratio } \\
\text { Exp[(O-E) / V], Fixed, 95\% C }\end{array}$} \\
\hline \multicolumn{11}{|c|}{ 1.1.1 Question 1: Regimen A (single) versus Regimen A + other } \\
\hline Tashiro H 1994 & 17 & 30 & 18 & 30 & 1.15 & 7.3 & $0.6 \%$ & $1.17[0.57,2.42]$ & & \\
\hline Ahmann DL 1974(1) & 18 & 21 & 20 & 22 & -2.89 & 6.95 & $0.5 \%$ & $0.66[0.31,1.39]$ & & - \\
\hline Ahmann DL 1974(2) & 18 & 20 & 16 & 20 & 0.85 & 4.92 & $0.4 \%$ & $1.19[0.49,2.88]$ & &. \\
\hline Albain KS 2004 & 214 & 267 & 212 & 262 & -26.47 & 101.37 & $8.0 \%$ & $0.77[0.63,0.94]$ & $\rightarrow$ & \\
\hline Andersson M 1986 & 32 & 44 & 34 & 45 & -0.85 & 17.45 & $1.4 \%$ & $0.95[0.60,1.52]$ & & 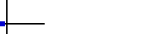 \\
\hline Carmo-Pereira 1980 & 49 & 68 & 62 & 67 & -22.08 & 26.03 & $2.0 \%$ & $0.43[0.29,0.63]$ & & \\
\hline Ejlertsen B 2004 & 112 & 193 & 105 & 194 & 7.78 & 55.74 & $4.4 \%$ & $1.15[0.88,1.49]$ & & $=$ \\
\hline Falkson G 1990 & 41 & 54 & 43 & 57 & 0.07 & 22.34 & $1.8 \%$ & $1.00[0.66,1.52]$ & 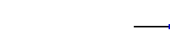 & 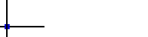 \\
\hline French Epi (A) 1991 & 86 & 135 & 47 & 70 & -2.94 & 44.66 & $3.5 \%$ & $0.94[0.70,1.26]$ & & E \\
\hline French Epi (B) 1991 & 84 & 137 & 47 & 70 & -4.77 & 29.53 & $2.3 \%$ & $0.85[0.59,1.22]$ & 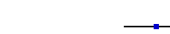 & L \\
\hline Gundersen S 1986 & 37 & 66 & 38 & 62 & -3.19 & 16.91 & $1.3 \%$ & $0.83[0.51,1.33]$ & . & - \\
\hline Heidemann E 2004 & 48 & 89 & 50 & 87 & -0.41 & 21.99 & $1.7 \%$ & $0.98[0.65,1.49]$ & - & 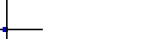 \\
\hline Ingle J 1985 & 70 & 79 & 70 & 79 & 0.77 & 38.32 & $3.0 \%$ & $1.02[0.74,1.40]$ & - & - \\
\hline Ingle J 1989 & 74 & 92 & 81 & 95 & -3.33 & 41.79 & $3.3 \%$ & $0.92[0.68,1.25]$ & 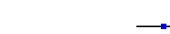 & L \\
\hline Joensuu H 1998 & 115 & 150 & 118 & 153 & -3.25 & 58.76 & $4.6 \%$ & $0.95[0.73,1.22]$ & & - \\
\hline Nielsen D 2000 & 68 & 74 & 62 & 81 & -5.93 & 25.53 & $2.0 \%$ & $0.79[0.54,1.17]$ & $\longrightarrow$ & - \\
\hline Nielson D 1990 & 52 & 65 & 63 & 76 & -1.63 & 17.07 & $1.3 \%$ & $0.91[0.57,1.46]$ & - & 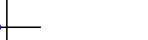 \\
\hline Norris B 2000 & 90 & 151 & 93 & 149 & -1.92 & 46.73 & $3.7 \%$ & $0.96[0.72,1.28]$ & & \\
\hline O'Shaughnessy J 2002 & 203 & 255 & 222 & 256 & -28.65 & 111.95 & $8.8 \%$ & $0.77[0.64,0.93]$ & $=$ & \\
\hline Rubens RD 1975 & 45 & 50 & 42 & 49 & -2.71 & 21.35 & $1.7 \%$ & $0.88[0.58,1.35]$ & 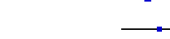 & - \\
\hline Sledge G(A) 2003 & 86 & 115 & 178 & 229 & -3.49 & 65.17 & $5.1 \%$ & $0.95[0.74,1.21]$ & & - \\
\hline Sledge G(B) 2003 & 86 & 115 & 174 & 224 & -0.55 & 62.86 & $4.9 \%$ & $0.99[0.77,1.27]$ & & - \\
\hline Takayama T(A) 2000 & 15 & 27 & 35 & 57 & -1.9 & 13.98 & $1.1 \%$ & $0.87[0.52,1.47]$ & & T. \\
\hline Takayama T(B) 2000 & 15 & 27 & 35 & 55 & -1.64 & 14.59 & $1.1 \%$ & $0.89[0.53,1.49]$ & 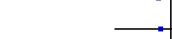 & . \\
\hline Vaughn CB 1988 & 51 & 59 & 56 & 63 & -5.43 & 28.04 & $2.2 \%$ & $0.82[0.57,1.19]$ & $\rightarrow$ & - \\
\hline Subtotal (95\% CI) & & 2383 & & 2552 & & & $70.9 \%$ & $0.88[0.83,0.94]$ & & \\
\hline Total events: & 1726 & & 1921 & & & & & & & \\
\hline \multicolumn{11}{|c|}{ Heterogeneity: $\mathrm{Chi}^{2}=27.04, \mathrm{df}=24(\mathrm{P}=0.30) ; \mathrm{I}^{2}=11 \%$} \\
\hline \multicolumn{11}{|c|}{ Test for overall effect: $\mathrm{Z}=3.78(\mathrm{P}=0.0002)$} \\
\hline \multicolumn{11}{|c|}{ 1.1.2 Question 2: Regimen A (single) versus Regimen C (combination) } \\
\hline Ahmann DL 1974(3) & 24 & 28 & 17 & 20 & -4.86 & 6.84 & $0.5 \%$ & $0.49[0.23,1.04]$ & & \\
\hline Bishop J 1999 & 84 & 102 & 79 & 107 & -13.08 & 38.87 & $3.1 \%$ & $0.71[0.52,0.98]$ & & \\
\hline Bonneterre J 2002 & 69 & 90 & 68 & 88 & 0.17 & 35.73 & $2.8 \%$ & $1.00[0.72,1.39]$ & & \\
\hline Canellos GP 1976 & 48 & 93 & 60 & 91 & -11.02 & 27.38 & $2.2 \%$ & $0.67[0.46,0.97]$ & & \\
\hline Fraser S 1993 & 12 & 19 & 15 & 21 & -2.44 & 6.23 & $0.5 \%$ & $0.68[0.31,1.48]$ & & \\
\hline Heidemann E 2002 & 75 & 127 & 86 & 133 & -7.05 & 41.54 & $3.3 \%$ & $0.84[0.62,1.14]$ & $\longrightarrow$ & - \\
\hline Icli F 2005 & 80 & 100 & 87 & 101 & -5.97 & 40.15 & $3.2 \%$ & $0.86[0.63,1.17]$ & $\longrightarrow$ & - \\
\hline Nabholtz JM 1999 & 150 & 189 & 141 & 203 & -24.33 & 74.66 & $5.9 \%$ & $0.72[0.58,0.91]$ & $\rightarrow$ & \\
\hline O'Shaughnessy J 2001 & 14 & 33 & 26 & 62 & -0.15 & 7.25 & $0.6 \%$ & $0.98[0.47,2.03]$ & 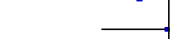 & \\
\hline Sjostrom J 1999 & 105 & 139 & 102 & 143 & -0.78 & 51.71 & $4.1 \%$ & $0.99[0.75,1.29]$ & - & — \\
\hline Stockler M 2006 & 63 & 109 & 104 & 214 & 15.55 & 40.32 & $3.2 \%$ & $1.47[1.08,2.00]$ & & 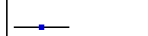 \\
\hline Subtotal $(95 \%$ CI) & & 1029 & & 1183 & & & $29.1 \%$ & $0.86[0.78,0.96]$ & & \\
\hline Total events: & 724 & & 785 & & & & & & & \\
\hline \multicolumn{11}{|c|}{ Heterogeneity: $\mathrm{Chi}^{2}=21.42, \mathrm{df}=10(\mathrm{P}=0.02) ; \mathrm{I}^{2}=53 \%$} \\
\hline \multicolumn{11}{|c|}{ Test for overall effect: $\mathrm{Z}=2.80(\mathrm{P}=0.005)$} \\
\hline Total (95\% CI) & & 3412 & & 3735 & & & $100.0 \%$ & $0.88[0.83,0.93]$ & $\Delta$ & \\
\hline Total events: & 2450 & & 2706 & & & & & & & \\
\hline \multicolumn{9}{|c|}{ Heterogeneity: $\mathrm{Chi}^{2}=48.56, \mathrm{df}=35(\mathrm{P}=0.06) ; \mathrm{I}^{2}=28 \%$} & $\begin{array}{ll} & 1 \\
0.2 & 0.5\end{array}$ & 2 \\
\hline Test for overall effect: Z & $1.69(\mathrm{P}<0$. & $0001)$ & & & & & & & urs combination & \\
\hline
\end{tabular}


Analysis 1.2. Comparison 1: Overall survival, Outcome 2: Overall survival - randomised patients - first line

\begin{tabular}{|c|c|c|c|c|c|c|c|c|c|c|}
\hline \multirow[b]{2}{*}{ Study or Subgroup } & \multicolumn{2}{|c|}{ Combination } & \multicolumn{2}{|c|}{ Single agent } & \multirow[b]{2}{*}{ O-E } & \multirow[b]{2}{*}{ Variance } & \multirow[b]{2}{*}{ Weight } & \multirow{2}{*}{$\begin{array}{c}\text { Hazard Ratio } \\
\operatorname{Exp}[(\mathrm{O}-\mathrm{E}) / \mathrm{V}], \text { Fixed, 95\% CI }\end{array}$} & \multirow{2}{*}{\multicolumn{2}{|c|}{$\begin{array}{c}\text { Hazard Ratio } \\
\operatorname{Exp}[(\mathrm{O}-\mathrm{E}) / \mathrm{V}], \text { Fixed, } 95 \% \mathrm{CI}\end{array}$}} \\
\hline & Events & Total & Events & Total & & & & & & \\
\hline \multicolumn{11}{|c|}{ 1.2.1 Question 1: Regimen A (single) versus Regimen A + other } \\
\hline Ahmann DL 1974(2) & 18 & 20 & 16 & 20 & 0.85 & 4.92 & $0.7 \%$ & $1.19[0.49,2.88]$ & & \\
\hline Albain KS 2004 & 214 & 267 & 212 & 262 & -26.47 & 101.37 & $14.9 \%$ & $0.77[0.63,0.94]$ & - & \\
\hline Carmo-Pereira 1980 & 49 & 68 & 62 & 67 & -22.08 & 26.03 & $3.8 \%$ & $0.43[0.29,0.63]$ & $\square-$ & \\
\hline Ejlertsen B 2004 & 115 & 193 & 112 & 194 & 6.72 & 57.85 & $8.5 \%$ & $1.12[0.87,1.45]$ & & $=$ \\
\hline Falkson G 1990 & 41 & 54 & 43 & 57 & 0.07 & 22.34 & $3.3 \%$ & $1.00[0.66,1.52]$ & - & - \\
\hline French Epi (A) 1991 & 86 & 135 & 47 & 70 & -2.94 & 44.66 & $6.6 \%$ & $0.94[0.70,1.26]$ & & - \\
\hline French Epi (B) 1991 & 84 & 137 & 47 & 70 & -4.77 & 29.53 & $4.3 \%$ & $0.85[0.59,1.22]$ & $\longrightarrow$ & - \\
\hline Gundersen S 1986 & 37 & 66 & 38 & 62 & -3.19 & 16.91 & $2.5 \%$ & $0.83[0.51,1.33]$ & $\longrightarrow$ & - \\
\hline Heidemann E 2004 & 48 & 89 & 50 & 87 & -0.41 & 21.99 & $3.2 \%$ & $0.98[0.65,1.49]$ & ב & - \\
\hline Ingle J 1985 & 70 & 79 & 70 & 79 & 0.77 & 38.32 & $5.6 \%$ & $1.02[0.74,1.40]$ & - & - \\
\hline Ingle J 1989 & 74 & 92 & 81 & 95 & -3.33 & 41.79 & $6.1 \%$ & $0.92[0.68,1.25]$ & - & \\
\hline Joensuu H 1998 & 115 & 150 & 118 & 153 & -3.25 & 58.76 & $8.6 \%$ & $0.95[0.73,1.22]$ & & - \\
\hline Nielsen D 2000 & 68 & 74 & 62 & 81 & -5.93 & 25.53 & $3.8 \%$ & $0.79[0.54,1.17]$ & $\longrightarrow$ & \\
\hline Rubens RD 1975 & 45 & 50 & 42 & 49 & -2.71 & 21.35 & $3.1 \%$ & $0.88[0.58,1.35]$ & $\longrightarrow$ & \\
\hline Subtotal (95\% CI) & & 1474 & & 1346 & & & $75.1 \%$ & $0.88[0.80,0.96]$ & & \\
\hline Total events: & 1064 & & 1000 & & & & & & & \\
\hline \multicolumn{11}{|c|}{ Heterogeneity: $\mathrm{Chi}^{2}=21.63, \mathrm{df}=13(\mathrm{P}=0.06) ; \mathrm{I}^{2}=40 \%$} \\
\hline \multicolumn{11}{|c|}{ Test for overall effect: $\mathrm{Z}=2.95(\mathrm{P}=0.003)$} \\
\hline \multicolumn{11}{|c|}{ 1.2.2 Question 2: Regimen A (single) versus Regimen C (combination) } \\
\hline Ahmann DL 1974(1) & 18 & 21 & 20 & 22 & -2.89 & 6.95 & $1.0 \%$ & $0.66[0.31,1.39]$ & . & - \\
\hline Ahmann DL 1974(3) & 24 & 28 & 17 & 20 & -4.86 & 6.84 & $1.0 \%$ & $0.49[0.23,1.04]$ & 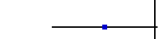 & \\
\hline Bishop J 1999 & 84 & 102 & 79 & 107 & -13.08 & 38.87 & $5.7 \%$ & $0.71[0.52,0.98]$ & $\rightarrow$ & \\
\hline Canellos GP 1976 & 48 & 93 & 60 & 91 & -11.02 & 27.38 & $4.0 \%$ & $0.67[0.46,0.97]$ & 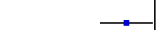 & \\
\hline Heidemann E 2002 & 75 & 127 & 86 & 133 & -7.05 & 41.54 & $6.1 \%$ & $0.84[0.62,1.14]$ & $\rightarrow$ & \\
\hline O'Shaughnessy J 2001 & 14 & 33 & 26 & 62 & -0.15 & 7.25 & $1.1 \%$ & $0.98[0.47,2.03]$ & & \\
\hline Stockler M 2006 & 63 & 109 & 104 & 214 & 15.55 & 40.32 & $5.9 \%$ & $1.47[1.08,2.00]$ & & $\longrightarrow-$ \\
\hline Subtotal $(95 \% \mathrm{CI})$ & & 513 & & 649 & & & $24.9 \%$ & $0.87[0.75,1.01]$ & & \\
\hline Total events: & 326 & & 392 & & & & & & & \\
\hline \multicolumn{11}{|c|}{ Heterogeneity: $\mathrm{Chi}^{2}=17.42, \mathrm{df}=6(\mathrm{P}=0.008) ; \mathrm{I}^{2}=66 \%$} \\
\hline \multicolumn{11}{|c|}{ Test for overall effect: $\mathrm{Z}=1.81(\mathrm{P}=0.07)$} \\
\hline Total $(95 \%$ CI) & & 1987 & & 1995 & & & $100.0 \%$ & $0.88[0.81,0.94]$ & $\Delta$ & \\
\hline Total events: & 1390 & & 1392 & & & & & & & \\
\hline \multirow{2}{*}{\multicolumn{8}{|c|}{$\begin{array}{l}\text { Heterogeneity: } \mathrm{Chi}^{2}=39.06, \mathrm{df}=20(\mathrm{P}=0.007) ; \mathrm{I}^{2}=49 \% \\
\text { Test for overall effect: } \mathrm{Z}=3.46(\mathrm{P}=0.0005)\end{array}$}} & & $\begin{array}{ccc}1 & 0.2 & 0.5\end{array}$ & 2 \\
\hline & & & & & & & & & ss combination & Favours singl \\
\hline
\end{tabular}


Analysis 1.3. Comparison 1: Overall survival, Outcome 3: Overall survival - Question 1 - Regimen A versus A + other - randomised patients

\begin{tabular}{|c|c|c|c|c|c|c|c|c|c|c|}
\hline \multirow[b]{2}{*}{ Study or Subgroup } & \multicolumn{2}{|c|}{ Combination } & \multicolumn{2}{|c|}{ Single agent } & \multirow[b]{2}{*}{ O-E } & \multirow[b]{2}{*}{ Variance } & \multirow[b]{2}{*}{ Weight } & \multirow{2}{*}{$\begin{array}{c}\text { Hazard Ratio } \\
\text { Exp[(O-E) / V], Fixed, 95\% CI }\end{array}$} & \multirow{2}{*}{\multicolumn{2}{|c|}{$\begin{array}{c}\text { Hazard Ratio } \\
\operatorname{Exp}[(\text { O-E) / V], Fixed, 95\% CI }\end{array}$}} \\
\hline & Events & Total & Events & Total & & & & & & \\
\hline \multicolumn{9}{|c|}{ 1.3.1 Sub group A: Single anthracycline agent versus anthracycline + other regimen } & & \\
\hline Andersson M 1986 & 32 & 44 & 34 & 45 & -0.85 & 17.45 & $1.9 \%$ & $0.95[0.60,1.52]$ & & - \\
\hline Ejlertsen B 2004 & 112 & 193 & 105 & 194 & 7.78 & 55.74 & $6.2 \%$ & $1.15[0.88,1.49]$ & & - \\
\hline French Epi (A) 1991 & 86 & 135 & 47 & 70 & -2.94 & 44.66 & $5.0 \%$ & $0.94[0.70,1.26]$ & & \\
\hline French Epi (B) 1991 & 84 & 137 & 47 & 70 & -4.77 & 29.53 & $3.3 \%$ & $0.85[0.59,1.22]$ & & \\
\hline Gundersen S 1986 & 37 & 66 & 38 & 62 & -3.19 & 16.91 & $1.9 \%$ & $0.83[0.51,1.33]$ & & \\
\hline Heidemann E 2004 & 48 & 89 & 50 & 87 & -0.41 & 21.99 & $2.4 \%$ & $0.98[0.65,1.49]$ & & - \\
\hline Ingle J 1985 & 70 & 79 & 70 & 79 & 0.77 & 38.32 & $4.3 \%$ & $1.02[0.74,1.40]$ & & - \\
\hline Ingle J 1989 & 74 & 92 & 81 & 95 & -3.33 & 41.79 & $4.6 \%$ & $0.92[0.68,1.25]$ & & \\
\hline Joensuu H 1998 & 115 & 150 & 118 & 153 & -3.25 & 58.76 & $6.5 \%$ & $0.95[0.73,1.22]$ & & \\
\hline Nielsen D 2000 & 68 & 74 & 62 & 81 & -5.93 & 25.53 & $2.8 \%$ & $0.79[0.54,1.17]$ & & - \\
\hline Nielson D 1990 & 52 & 65 & 63 & 76 & -1.63 & 17.07 & $1.9 \%$ & $0.91[0.57,1.46]$ & & \\
\hline Norris B 2000 & 90 & 151 & 93 & 149 & -1.92 & 46.75 & $5.2 \%$ & $0.96[0.72,1.28]$ & & \\
\hline Sledge G(A) 2003 & 86 & 115 & 174 & 224 & -0.55 & 62.86 & $7.0 \%$ & $0.99[0.77,1.27]$ & & \\
\hline Vaughn CB 1988 & 51 & 59 & 56 & 63 & -5.43 & 28.04 & $3.1 \%$ & $0.82[0.57,1.19]$ & & \\
\hline Subtotal $(95 \% \mathrm{CI})$ & & 1449 & & 1448 & & & $56.1 \%$ & $0.95[0.87,1.04]$ & & \\
\hline Total events: & 1005 & & 1038 & & & & & & & \\
\hline \multicolumn{11}{|c|}{ Heterogeneity: $\mathrm{Chi}^{2}=4.53, \mathrm{df}=13(\mathrm{P}=0.98) ; \mathrm{I}^{2}=0 \%$} \\
\hline \multicolumn{11}{|c|}{ Test for overall effect: $\mathrm{Z}=1.14(\mathrm{P}=0.25)$} \\
\hline \multicolumn{11}{|c|}{ 1.3.2 Sub group B: Single alkylating versus alkylating + other } \\
\hline Ahmann DL 1974(1) & 18 & 21 & 20 & 22 & -2.89 & 6.95 & $0.8 \%$ & $0.66[0.31,1.39]$ & & - \\
\hline Ahmann DL 1974(2) & 18 & 20 & 16 & 20 & 0.85 & 4.92 & $0.5 \%$ & $1.19[0.49,2.88]$ & & \\
\hline Falkson G 1990 & 41 & 54 & 43 & 57 & 0.07 & 22.34 & $2.5 \%$ & $1.00[0.66,1.52]$ & & \\
\hline Rubens RD 1975 & 45 & 50 & 42 & 49 & -2.71 & 21.35 & $2.4 \%$ & $0.88[0.58,1.35]$ & & - \\
\hline Takayama T(B) 2000 & 15 & 27 & 35 & 55 & -1.64 & 14.59 & $1.6 \%$ & $0.89[0.53,1.49]$ & & \\
\hline Subtotal (95\% CI) & & 172 & & 203 & & & $7.8 \%$ & $0.91[0.72,1.15]$ & & \\
\hline Total events: & 137 & & 156 & & & & & & & \\
\hline \multicolumn{11}{|c|}{ Heterogeneity: $\mathrm{Chi}^{2}=1.31, \mathrm{df}=4(\mathrm{P}=0.86) ; \mathrm{I}^{2}=0 \%$} \\
\hline \multicolumn{11}{|c|}{ Test for overall effect: $\mathrm{Z}=0.75(\mathrm{P}=0.45)$} \\
\hline \multicolumn{11}{|c|}{ 1.3.3 Sub group C: Single antimetabolite versus antimetabolite + other } \\
\hline Tashiro H 1994 & 17 & 30 & 18 & 30 & 1.15 & 7.3 & $0.8 \%$ & $1.17[0.57,2.42]$ & & \\
\hline Carmo-Pereira 1980 & 49 & 68 & 62 & 67 & -22.08 & 26.03 & $2.9 \%$ & $0.43[0.29,0.63]$ & $\rightarrow$ & \\
\hline Takayama T(A) 2000 & 15 & 27 & 35 & 57 & -1.9 & 13.98 & $1.6 \%$ & $0.87[0.52,1.47]$ & & \\
\hline Subtotal (95\% CI) & & 125 & & 154 & & & $5.2 \%$ & $0.62[0.46,0.82]$ & & \\
\hline Total events: & 81 & & 115 & & & & & & & \\
\hline \multicolumn{11}{|c|}{ Heterogeneity: $\mathrm{Chi}^{2}=8.15, \mathrm{df}=2(\mathrm{P}=0.02) ; \mathrm{I}^{2}=75 \%$} \\
\hline \multicolumn{11}{|c|}{ Test for overall effect: $\mathrm{Z}=3.32(\mathrm{P}=0.0009)$} \\
\hline \multicolumn{11}{|c|}{ 1.3.4 Sub group D: Single taxane versus taxane + other } \\
\hline Albain KS 2004 & 214 & 267 & 212 & 262 & -26.47 & 101.37 & $11.2 \%$ & $0.77[0.63,0.94]$ & $\rightarrow$ & \\
\hline O'Shaughnessy J 2002 & 203 & 255 & 222 & 256 & -28.65 & 111.95 & $12.4 \%$ & $0.77[0.64,0.93]$ & 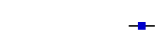 & \\
\hline Sledge G(B) 2003 & 86 & 115 & 178 & 229 & -3.49 & 65.17 & $7.2 \%$ & $0.95[0.74,1.21]$ & $\rightarrow$ & \\
\hline Subtotal $(95 \% \mathrm{CI})$ & & 637 & & 747 & & & $30.9 \%$ & $0.81[0.72,0.91]$ & 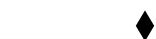 & \\
\hline Total events: & 503 & & 612 & & & & & & & \\
\hline Heterogeneity: $\mathrm{Chi}^{2}=2$ & $\mathrm{df}=2(\mathrm{P}=$ & $0.35) ; I^{2}=$ & $=5 \%$ & & & & & & & \\
\hline Test for overall effect: & $3.51(\mathrm{P}=0$. & 004) & & & & & & & & \\
\hline Total (95\% CI) & & 2383 & & 2552 & & & $100.0 \%$ & $0.88[0.83,0.94]$ & 1 & \\
\hline Total events: & 1726 & & 1921 & & & & & & & \\
\hline Heterogeneity: $\mathrm{Chi}^{2}=2$ &, $\mathrm{df}=24(\mathrm{P}$ & $=0.30) ; \mathrm{I}^{2}$ & $2=11 \%$ & & & & & & $\begin{array}{ll}1 & 0.2 \\
\end{array}$ & 2 \\
\hline Test for overall effect: & $3.78(\mathrm{P}=0$ & 002) & & & & & & & rs combination & Favours sin \\
\hline
\end{tabular}


Analysis 1.4. Comparison 1: Overall survival, Outcome 4: Overall survival - Question 2 - Regimen A versus Regimen C - randomised patients

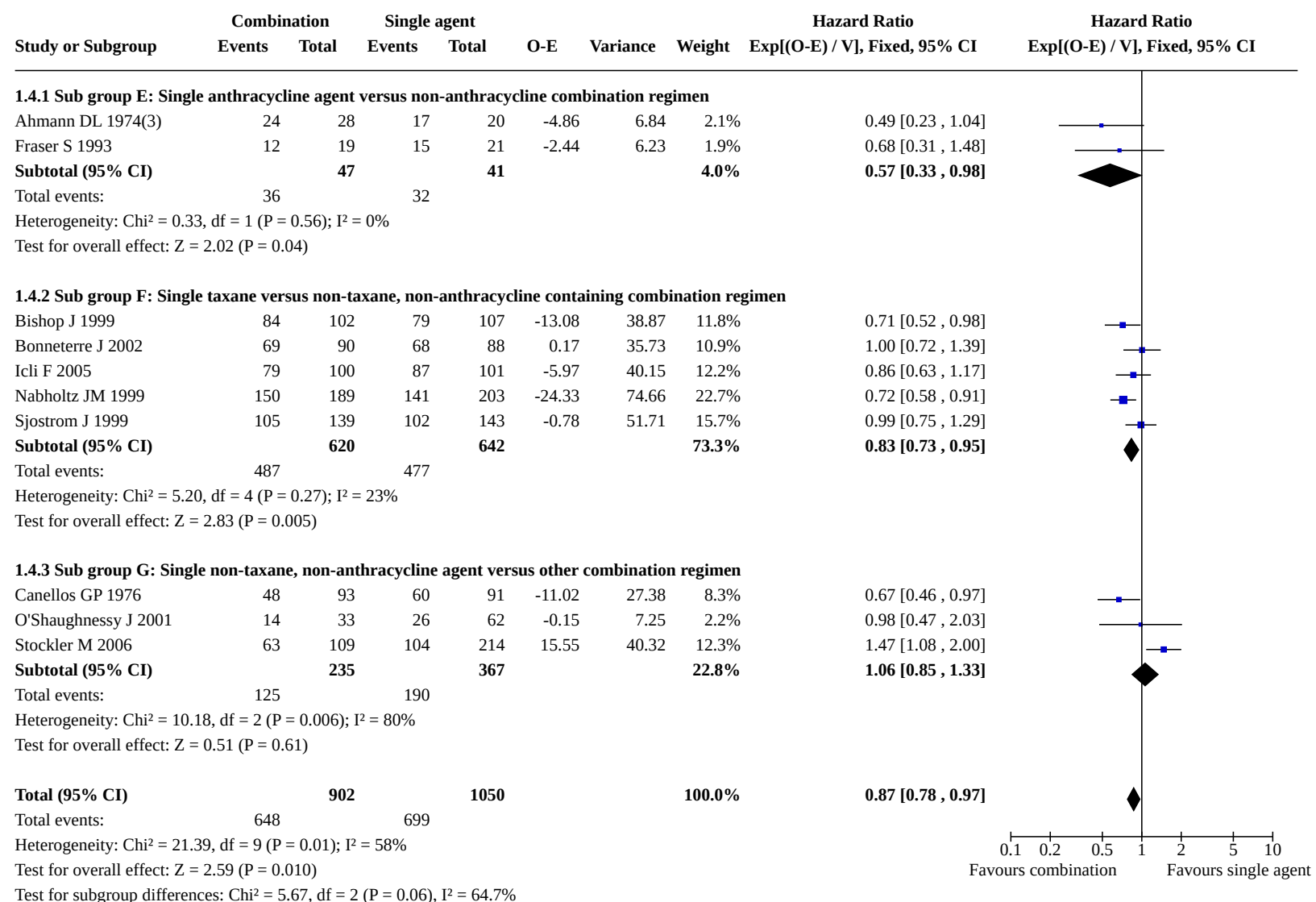

Analysis 1.5. Comparison 1: Overall survival, Outcome 5: Overall survival - single agent taxane versus all combination

\begin{tabular}{|c|c|c|c|c|c|c|c|c|c|c|}
\hline \multirow[b]{2}{*}{ Study or Subgroup } & \multicolumn{2}{|c|}{ Combination } & \multicolumn{2}{|c|}{ Single agent } & \multirow[b]{2}{*}{ O-E } & \multirow[b]{2}{*}{ Variance } & \multirow[b]{2}{*}{ Weight } & \multirow{2}{*}{$\begin{array}{c}\text { Hazard Ratio } \\
\text { Exp[(O-E) / V], Fixed, 95\% CI }\end{array}$} & \multirow{2}{*}{\multicolumn{2}{|c|}{$\begin{array}{c}\text { Hazard Ratio } \\
\operatorname{Exp}[(\text { O-E) / V], Fixed, 95\% CI }\end{array}$}} \\
\hline & Events & Total & Events & Total & & & & & & \\
\hline Albain KS 2004 & 214 & 267 & 212 & 262 & -26.47 & 101.37 & $19.5 \%$ & $0.77[0.63,0.94]$ & $\rightarrow$ & \\
\hline Bishop J 1999 & 84 & 102 & 79 & 107 & -13.08 & 38.87 & $7.5 \%$ & $0.71[0.52,0.98]$ & $\rightarrow$ & \\
\hline Bonneterre J 2002 & 69 & 90 & 68 & 88 & 0.17 & 35.73 & $6.9 \%$ & $1.00[0.72,1.39]$ & 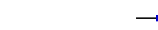 & \\
\hline Icli F 2005 & 79 & 100 & 87 & 101 & -5.97 & 40.15 & $7.7 \%$ & $0.86[0.63,1.17]$ & 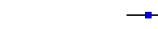 & \\
\hline Nabholtz JM 1999 & 150 & 189 & 141 & 203 & -24.33 & 74.66 & $14.4 \%$ & $0.72[0.58,0.91]$ & $\rightarrow$ & \\
\hline O'Shaughnessy J 2002 & 203 & 255 & 222 & 256 & -28.65 & 111.95 & $21.5 \%$ & $0.77[0.64,0.93]$ & $\because$ & \\
\hline Sjostrom J 1999 & 105 & 139 & 102 & 143 & -0.78 & 51.71 & $10.0 \%$ & $0.99[0.75,1.29]$ & - & \\
\hline Sledge G(A) 2003 & 86 & 115 & 178 & 229 & -3.49 & 65.17 & $12.5 \%$ & $0.95[0.74,1.21]$ & $\rightarrow$ & \\
\hline Total $(95 \%$ CI $)$ & & 1257 & & 1389 & & & $100.0 \%$ & $0.82[0.75,0.89]$ & $\boldsymbol{\theta}$ & \\
\hline Total events: & 990 & & 1089 & & & & & & & \\
\hline \multicolumn{5}{|c|}{ Heterogeneity: Chi $^{2}=7.40, \mathrm{df}=7(\mathrm{P}=0.39) ; \mathrm{I}^{2}=5 \%$} & & & & & 10.2 . & 25 \\
\hline \multicolumn{4}{|c|}{ Test for overall effect: $\mathrm{Z}=4.50(\mathrm{P}<0.00001)$} & & & & & Fav & rs combination & Favours sin \\
\hline
\end{tabular}




\section{Analysis 1.6. Comparison 1: Overall survival, Outcome 6: Overall survival - single agent anthracycline versus all combinations}

\begin{tabular}{|c|c|c|c|c|c|c|c|c|c|c|}
\hline \multirow[b]{2}{*}{ Study or Subgroup } & \multicolumn{2}{|c|}{ Combination } & \multicolumn{2}{|c|}{ Single agent } & \multirow[b]{2}{*}{ O-E } & \multirow[b]{2}{*}{ Variance } & \multirow[b]{2}{*}{ Weight } & Hazard Ratio & \multicolumn{2}{|c|}{ Hazard Ratio } \\
\hline & Events & Total & Events & Total & & & & $\operatorname{Exp}[(0-E) /$ V], Fixed, 95\% CI & $\operatorname{Exp}[(O-E) / V]$, & Fixed, 95\% CI \\
\hline Ahmann DL 1974(3) & 24 & 28 & 17 & 20 & -4.86 & 6.84 & $1.3 \%$ & $0.49[0.23,1.04]$ & & \\
\hline Andersson M 1986 & 32 & 44 & 34 & 45 & -0.85 & 17.45 & $3.4 \%$ & $0.95[0.60,1.52]$ & & \\
\hline Ejlertsen B 2004 & 112 & 193 & 105 & 194 & 7.78 & 55.74 & $10.8 \%$ & $1.15[0.88,1.49]$ & & - \\
\hline Fraser S 1993 & 12 & 19 & 15 & 21 & -2.44 & 6.23 & $1.2 \%$ & $0.68[0.31,1.48]$ & & - \\
\hline French Epi (A) 1991 & 86 & 135 & 47 & 70 & -2.94 & 44.66 & $8.6 \%$ & $0.94[0.70,1.26]$ & & \\
\hline French Epi (B) 1991 & 84 & 137 & 47 & 70 & -4.77 & 29.53 & $5.7 \%$ & $0.85[0.59,1.22]$ & $\longrightarrow$ & \\
\hline Gundersen S 1986 & 37 & 66 & 38 & 62 & -3.19 & 16.91 & $3.3 \%$ & $0.83[0.51,1.33]$ & . & \\
\hline Heidemann E 2004 & 48 & 89 & 50 & 87 & -0.41 & 21.99 & $4.2 \%$ & $0.98[0.65,1.49]$ & & \\
\hline Ingle J 1985 & 70 & 79 & 70 & 79 & 0.77 & 38.32 & $7.4 \%$ & $1.02[0.74,1.40]$ & & \\
\hline Ingle J 1989 & 74 & 92 & 81 & 95 & -3.33 & 41.79 & $8.1 \%$ & $0.92[0.68,1.25]$ & - & \\
\hline Joensuu H 1998 & 115 & 150 & 118 & 153 & -3.25 & 58.76 & $11.3 \%$ & $0.95[0.73,1.22]$ & & \\
\hline Nielsen D 2000 & 68 & 74 & 62 & 81 & -5.93 & 25.53 & $4.9 \%$ & $0.79[0.54,1.17]$ & $\longrightarrow$ & \\
\hline Nielson D 1990 & 52 & 65 & 63 & 76 & -1.63 & 17.07 & $3.3 \%$ & $0.91[0.57,1.46]$ & & \\
\hline Norris B 2000 & 90 & 151 & 93 & 149 & -1.92 & 46.75 & $9.0 \%$ & $0.96[0.72,1.28]$ & & \\
\hline Sledge G(A) 2003 & 86 & 115 & 174 & 224 & -0.55 & 62.86 & $12.1 \%$ & $0.99[0.77,1.27]$ & & \\
\hline Vaughn CB 1988 & 51 & 59 & 56 & 63 & -5.43 & 28.04 & $5.4 \%$ & $0.82[0.57,1.19]$ & & \\
\hline Total (95\% CI) & & 1496 & & 1489 & & & $100.0 \%$ & $0.94[0.86,1.02]$ & & \\
\hline Total events: & 1041 & & 1070 & & & & & & & \\
\hline \multirow{2}{*}{\multicolumn{4}{|c|}{$\begin{array}{l}\text { Heterogeneity: } \mathrm{Chi}^{2}=8.14, \mathrm{df}=15(\mathrm{P}=0.92) ; \mathrm{I}^{2}=0 \% \\
\text { Test for overall effect: } \mathrm{Z}=1.45(\mathrm{P}=0.15)\end{array}$}} & & & & & & $\begin{array}{ccc} & 1 & 1 \\
0.1 & 0.2 & 0.5\end{array}$ & $\begin{array}{ll}1 & 1 \\
2 & 5\end{array}$ \\
\hline & & & & & & & & & ours combination & Favours sing \\
\hline
\end{tabular}

\section{Comparison 2. Time to progression}

\begin{tabular}{|c|c|c|c|c|}
\hline Outcome or subgroup title & No. of studies & $\begin{array}{l}\text { No. of partici- } \\
\text { pants }\end{array}$ & Statistical method & Effect size \\
\hline $\begin{array}{l}2.1 \text { Time to progression - randomised pa- } \\
\text { tients - all trials }\end{array}$ & 27 & 6501 & $\begin{array}{l}\text { Hazard Ratio }(\operatorname{Exp}[(\mathrm{O}-\mathrm{E}) / \\
\text { V], Fixed, } 95 \% \mathrm{Cl})\end{array}$ & $0.78[0.74,0.82]$ \\
\hline $\begin{array}{l}\text { 2.1.1 Question 1: Regimen A (single) vs } \\
\text { Regimen A + other }\end{array}$ & 18 & 4521 & $\begin{array}{l}\text { Hazard Ratio }(\operatorname{Exp}[(\mathrm{O}-\mathrm{E}) / \\
\text { V], Fixed, } 95 \% \mathrm{Cl})\end{array}$ & $0.76[0.71,0.80]$ \\
\hline $\begin{array}{l}\text { 2.1.2 Question 2: Regimen A (single) vs } \\
\text { Regimen C (combination) }\end{array}$ & 9 & 1980 & $\begin{array}{l}\text { Hazard Ratio }(\operatorname{Exp}[(\mathrm{O}-\mathrm{E}) / \\
\text { V], Fixed, } 95 \% \mathrm{Cl})\end{array}$ & $0.85[0.78,0.93]$ \\
\hline $\begin{array}{l}2.2 \text { Time to progression - randomised pa- } \\
\text { tients - first line }\end{array}$ & 13 & 3201 & $\begin{array}{l}\text { Hazard Ratio }(\operatorname{Exp}[(\mathrm{O}-\mathrm{E}) / \\
\text { V], Fixed, } 95 \% \mathrm{Cl})\end{array}$ & $0.87[0.81,0.94]$ \\
\hline $\begin{array}{l}\text { 2.2.1 Question 1: Regimen A (single) ver- } \\
\text { sus Regimen A + other }\end{array}$ & 9 & 2314 & $\begin{array}{l}\text { Hazard Ratio }(\operatorname{Exp}[(\mathrm{O}-\mathrm{E}) / \\
\text { V], Fixed, } 95 \% \mathrm{Cl})\end{array}$ & $0.81[0.74,0.88]$ \\
\hline $\begin{array}{l}\text { 2.2.2 Question 2: Regimen A (single) ver- } \\
\text { sus Regimen C (combination) }\end{array}$ & 4 & 887 & $\begin{array}{l}\text { Hazard Ratio }(\operatorname{Exp}[(\mathrm{O}-\mathrm{E}) / \\
\text { V], Fixed, } 95 \% \mathrm{Cl})\end{array}$ & $1.08[0.94,1.25]$ \\
\hline $\begin{array}{l}\text { 2.3 Time to progression - Question } 1 \text { - } \\
\text { Regimen A versus A + other - randomised } \\
\text { patients }\end{array}$ & 16 & 3518 & $\begin{array}{l}\text { Hazard Ratio }(\operatorname{Exp}[(\mathrm{O}-\mathrm{E}) / \\
\text { V], Fixed, } 95 \% \mathrm{Cl})\end{array}$ & $0.77[0.72,0.83]$ \\
\hline $\begin{array}{l}\text { 2.3.1 Sub Group A: Single anthracycline } \\
\text { agent versus anthracycline + other regi- } \\
\text { men }\end{array}$ & 12 & 2312 & $\begin{array}{l}\text { Hazard Ratio }(\operatorname{Exp}[(\mathrm{O}-\mathrm{E}) / \\
\text { V], Fixed, } 95 \% \mathrm{Cl})\end{array}$ & $0.82[0.75,0.89]$ \\
\hline $\begin{array}{l}\text { 2.3.2 Sub group B: Single alkylating agent } \\
\text { versus alkylating agent + other }\end{array}$ & 1 & 82 & $\begin{array}{l}\text { Hazard Ratio }(\operatorname{Exp}[(\mathrm{O}-\mathrm{E}) / \\
\text { V], Fixed, } 95 \% \mathrm{Cl})\end{array}$ & $0.55[0.36,0.84]$ \\
\hline
\end{tabular}




\begin{tabular}{|c|c|c|c|c|}
\hline Outcome or subgroup title & No. of studies & $\begin{array}{l}\text { No. of partici- } \\
\text { pants }\end{array}$ & Statistical method & Effect size \\
\hline $\begin{array}{l}\text { 2.3.3 Sub group C: Single antimetabolite } \\
\text { versus antimetaboloite + other }\end{array}$ & 1 & 84 & $\begin{array}{l}\text { Hazard Ratio }(\operatorname{Exp}[(\mathrm{O}-\mathrm{E}) / \\
\text { V], Fixed, } 95 \% \mathrm{Cl})\end{array}$ & $0.84[0.54,1.28]$ \\
\hline $\begin{array}{l}\text { 2.3.4 Sub group D: Single taxane versus } \\
\text { taxane + other }\end{array}$ & 2 & 1040 & $\begin{array}{l}\text { Hazard Ratio }(\operatorname{Exp}[(\mathrm{O}-\mathrm{E}) / \\
\text { V], Fixed, } 95 \% \mathrm{Cl})\end{array}$ & $0.69[0.61,0.78]$ \\
\hline $\begin{array}{l}\text { 2.4 Time to progression - Question } 2 \\
\text { - Regimen A versus Regimen C - ran- } \\
\text { domised patients }\end{array}$ & 8 & 1720 & $\begin{array}{l}\text { Hazard Ratio }(\operatorname{Exp}[(\mathrm{O}-\mathrm{E}) / \\
\text { V], Fixed, } 95 \% \mathrm{CI})\end{array}$ & $0.78[0.71,0.86]$ \\
\hline $\begin{array}{l}\text { 2.4.1 Sub group E - Single anthracycline } \\
\text { agent versus non-anthracycline combina- } \\
\text { tion regimen }\end{array}$ & 1 & 40 & $\begin{array}{l}\text { Hazard Ratio }(\operatorname{Exp}[(\mathrm{O}-\mathrm{E}) / \\
\text { V], Fixed, } 95 \% \mathrm{CI})\end{array}$ & $0.52[0.26,1.02]$ \\
\hline $\begin{array}{l}\text { 2.4.2 Sub group F - Single taxane versus } \\
\text { non-taxane, non-anthacycline containing } \\
\text { combination regimen }\end{array}$ & 5 & 1262 & $\begin{array}{l}\text { Hazard Ratio }(\operatorname{Exp}[(\mathrm{O}-\mathrm{E}) / \\
\text { V], Fixed, } 95 \% \mathrm{Cl})\end{array}$ & $0.75[0.67,0.84]$ \\
\hline $\begin{array}{l}\text { 2.4.3 Sub group G - Single non-taxane, } \\
\text { non-anthracycline agent versus other } \\
\text { combination regimen }\end{array}$ & 2 & 418 & $\begin{array}{l}\text { Hazard Ratio }(\operatorname{Exp}[(\mathrm{O}-\mathrm{E}) / \\
\text { V], Fixed, } 95 \% \mathrm{Cl})\end{array}$ & $0.95[0.77,1.17]$ \\
\hline $\begin{array}{l}\text { 2.5 Time to progression - single agent tax- } \\
\text { ane versus all combinations }\end{array}$ & 7 & 2302 & $\begin{array}{l}\text { Hazard Ratio (Exp[(O-E) / } \\
\text { V], Fixed, } 95 \% \mathrm{Cl})\end{array}$ & $0.72[0.67,0.79]$ \\
\hline $\begin{array}{l}2.6 \text { Time to progression - Single agent an- } \\
\text { thracycline versus all combinations }\end{array}$ & 13 & 2352 & $\begin{array}{l}\text { Peto Odds Ratio (Ex- } \\
\text { p[(O-E) / V], Fixed, } 95 \% \text { Cl) }\end{array}$ & $0.82[0.75,0.89]$ \\
\hline
\end{tabular}


Analysis 2.1. Comparison 2: Time to progression, Outcome 1: Time to progression - randomised patients - all trials

\begin{tabular}{|c|c|c|c|c|c|c|c|c|c|c|}
\hline \multirow[b]{2}{*}{ Study or Subgroup } & \multicolumn{2}{|c|}{ Combination } & \multicolumn{2}{|c|}{ Single agent } & \multirow[b]{2}{*}{ O-E } & \multirow[b]{2}{*}{ Variance } & \multirow[b]{2}{*}{ Weight } & \multirow{2}{*}{$\begin{array}{c}\text { Hazard Ratio } \\
\operatorname{Exp}[(\mathrm{O}-\mathrm{E}) / \mathrm{V}] \text {, Fixed, } 95 \% \text { CI }\end{array}$} & \multirow{2}{*}{\multicolumn{2}{|c|}{$\begin{array}{c}\text { Hazard Ratio } \\
\operatorname{Exp}[(0-\mathrm{E}) / \text { V], Fixed, 95\% C }\end{array}$}} \\
\hline & Events & Total & Events & Total & & & & & & \\
\hline \multicolumn{10}{|c|}{ 2.1.1 Question 1: Regimen A (single) vs Regimen A + other } & \\
\hline Albain KS 2004 & 180 & 267 & 197 & 262 & -38.69 & 104.65 & $6.8 \%$ & $0.69[0.57,0.84]$ & $\rightarrow$ & \\
\hline Andersson M 1986 & 29 & 44 & 35 & 45 & -9.31 & 16.69 & $1.1 \%$ & $0.57[0.35,0.92]$ & $\longrightarrow$ & \\
\hline Berruti D 2002 & 78 & 92 & 81 & 93 & -2.06 & 39.98 & $2.6 \%$ & $0.95[0.70,1.29]$ & & \\
\hline Ejlertsen B 2004 & 141 & 193 & 155 & 194 & -20.78 & 79.13 & $5.2 \%$ & $0.77[0.62,0.96]$ & $\rightarrow$ & \\
\hline French Epi (A) 1991 & 110 & 135 & 56 & 70 & -1.68 & 60.31 & $3.9 \%$ & $0.97[0.76,1.25]$ & & - \\
\hline French Epi (B) 1991 & 105 & 137 & 56 & 70 & -10.13 & 55.83 & $3.6 \%$ & $0.83[0.64,1.08]$ & $=$ & \\
\hline GEICAM 2007 & 102 & 125 & 111 & 126 & -22.88 & 70.08 & $4.6 \%$ & $0.72[0.57,0.91]$ & $\rightarrow$ & \\
\hline Heidemann E 2004 & 63 & 89 & 71 & 87 & -8.58 & 29.9 & $1.9 \%$ & $0.75[0.52,1.07]$ & $=$ & \\
\hline Ingle J 1985 & 75 & 79 & 75 & 79 & 0.47 & 54.3 & $3.5 \%$ & $1.01[0.77,1.32]$ & & \\
\hline Ingle J 1989 & 79 & 90 & 90 & 95 & -20.92 & 54.49 & $3.6 \%$ & $0.68[0.52,0.89]$ & - & \\
\hline Joensuu H 1998 & 124 & 150 & 129 & 153 & -15.38 & 56.17 & $3.7 \%$ & $0.76[0.59,0.99]$ & $\rightarrow$ & \\
\hline Nielsen D 2000 & 61 & 74 & 68 & 81 & -3.62 & 22.78 & $1.5 \%$ & $0.85[0.57,1.29]$ & & \\
\hline Nielson D 1990 & 59 & 67 & 69 & 76 & -3.57 & 41.35 & $2.7 \%$ & $0.92[0.68,1.24]$ & - & - \\
\hline O'Shaughnessy J 2002 & 231 & 255 & 250 & 256 & -53.4 & 139.9 & $9.1 \%$ & $0.68[0.58,0.81]$ & $=$ & \\
\hline Takayama T(A) 2000 & 19 & 27 & 43 & 57 & -3.77 & 20.98 & $1.4 \%$ & $0.84[0.54,1.28]$ & & - \\
\hline Takayama T(B) 2000 & 19 & 27 & 47 & 55 & -12.8 & 21.31 & $1.4 \%$ & $0.55[0.36,0.84]$ & - & \\
\hline Thomas E 2008 & 302 & 375 & 322 & 377 & -59.92 & 167.88 & $10.9 \%$ & $0.70[0.60,0.81]$ & - & \\
\hline Vaughn CB 1988 & 45 & 56 & 59 & 63 & -10.55 & 26.74 & $1.7 \%$ & $0.67[0.46,0.98]$ & $\longrightarrow$ & \\
\hline Subtotal $(95 \%$ CI) & & 2282 & & 2239 & & & $69.2 \%$ & $0.76[0.71,0.80]$ & 1 & \\
\hline Total events: & 1822 & & 1914 & & & & & & & \\
\hline \multicolumn{11}{|c|}{ Heterogeneity: $\mathrm{Chi}^{2}=20.96, \mathrm{df}=17(\mathrm{P}=0.23) ; \mathrm{I}^{2}=19 \%$} \\
\hline \multicolumn{11}{|c|}{ Test for overall effect: $\mathrm{Z}=9.13(\mathrm{P}<0.00001)$} \\
\hline \multicolumn{11}{|c|}{ 2.1.2 Question 2: Regimen A (single) vs Regimen C (combination) } \\
\hline Bishop J 1999 & 99 & 102 & 102 & 107 & 8.72 & 51.88 & $3.4 \%$ & $1.18[0.90,1.55]$ & & $=$ \\
\hline Bonneterre J 2002 & 86 & 90 & 83 & 88 & 5 & 44.39 & $2.9 \%$ & $1.12[0.83,1.50]$ & & - \\
\hline Fraser S 1993 & 15 & 19 & 20 & 21 & -5.48 & 8.33 & $0.5 \%$ & $0.52[0.26,1.02]$ & & \\
\hline Heidemann E 2002 & 98 & 127 & 101 & 133 & 2.37 & 54.84 & $3.6 \%$ & $1.04[0.80,1.36]$ & & - \\
\hline Icli F 2005 & 91 & 100 & 98 & 101 & -28.56 & 53.69 & $3.5 \%$ & $0.59[0.45,0.77]$ & $\rightarrow$ & \\
\hline Nabholtz JM 1999 & 174 & 189 & 179 & 203 & -37.69 & 99.42 & $6.5 \%$ & $0.68[0.56,0.83]$ & $\rightarrow$ & \\
\hline O'Shaughnessy J 2001 & 27 & 33 & 48 & 62 & 5.88 & 20.72 & $1.4 \%$ & $1.33[0.86,2.04]$ & &. \\
\hline Sjostrom J 1999 & 132 & 139 & 128 & 143 & -38.38 & 70.58 & $4.6 \%$ & $0.58[0.46,0.73]$ & $\rightarrow$ & \\
\hline Stockler M 2006 & 93 & 109 & 170 & 214 & 10.44 & 68.14 & $4.4 \%$ & $1.17[0.92,1.48]$ & & $=$ \\
\hline Subtotal $(95 \%$ CI) & & 908 & & 1072 & & & $30.8 \%$ & $0.85[0.78,0.93]$ & & \\
\hline Total events: & 815 & & 929 & & & & & & & \\
\hline \multicolumn{11}{|c|}{ Heterogeneity: Chi $^{2}=46.56, \mathrm{df}=8(\mathrm{P}<0.00001) ; \mathrm{I}^{2}=83 \%$} \\
\hline \multicolumn{11}{|c|}{ Test for overall effect: $\mathrm{Z}=3.58(\mathrm{P}=0.0003)$} \\
\hline Total (95\% CI) & & 3190 & & 3311 & & & $100.0 \%$ & $0.78[0.74,0.82]$ & 1 & \\
\hline Total events: & 2637 & & 2843 & & & & & & & \\
\hline \multirow{2}{*}{\multicolumn{8}{|c|}{$\begin{array}{l}\text { Heterogeneity: } \mathrm{Chi}^{2}=71.88, \mathrm{df}=26(\mathrm{P}<0.00001) ; \mathrm{I}^{2}=64 \% \\
\text { Test for overall effect: } \mathrm{Z}=9.58(\mathrm{P}<0.00001)\end{array}$}} & & $\begin{array}{lll}1 & 1 & 1 \\
1 & 0.2 & 0.5\end{array}$ & 2 \\
\hline & & & & & & & & & rs combination & Favours sin \\
\hline
\end{tabular}


Analysis 2.2. Comparison 2: Time to progression, Outcome 2: Time to progression - randomised patients - first line

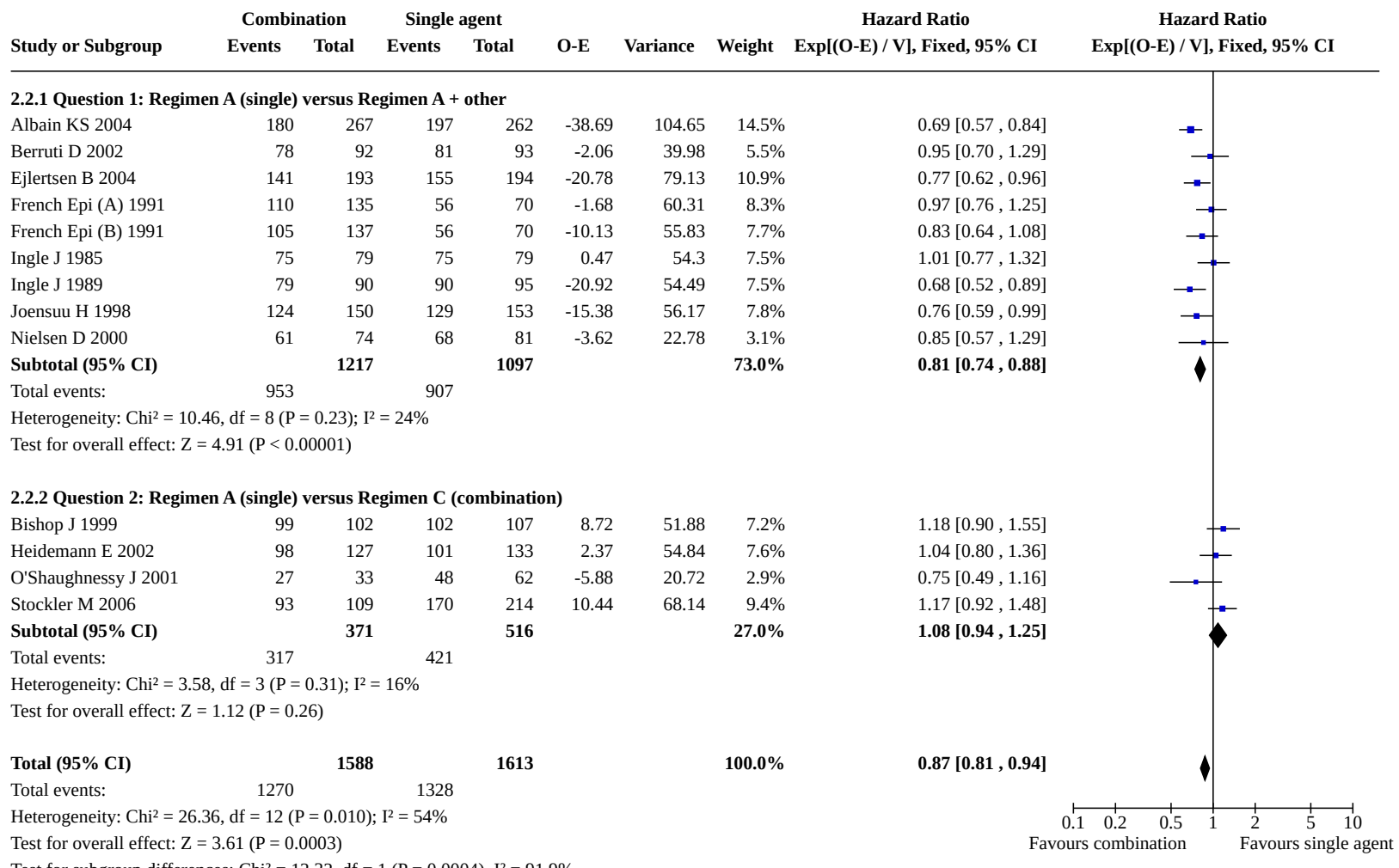


Analysis 2.3. Comparison 2: Time to progression, Outcome 3: Time to progression - Question 1 - Regimen A versus A + other - randomised patients

\begin{tabular}{|c|c|c|c|c|c|c|c|c|c|c|}
\hline \multirow[b]{2}{*}{ Study or Subgroup } & \multicolumn{2}{|c|}{ Combination } & \multicolumn{2}{|c|}{ Single agent } & \multirow[b]{2}{*}{ O-E } & \multirow[b]{2}{*}{ Variance } & \multirow[b]{2}{*}{ Weight } & \multirow{2}{*}{$\begin{array}{c}\text { Hazard Ratio } \\
\operatorname{Exp}[(\mathrm{O}-\mathrm{E}) / \mathrm{V}], \text { Fixed, 95\% CI }\end{array}$} & \multirow{2}{*}{\multicolumn{2}{|c|}{$\begin{array}{c}\text { Hazard Ratio } \\
\operatorname{Exp}[(\mathrm{O}-\mathrm{E}) / \mathrm{V}] \text {, Fixed, 95\% CI }\end{array}$}} \\
\hline & Events & Total & Events & Total & & & & & & \\
\hline \multicolumn{10}{|c|}{ 2.3.1 Sub Group A: Single anthracycline agent versus anthracycline + other regimen } & \\
\hline Andersson M 1986 & 29 & 44 & 35 & 45 & -9.31 & 16.69 & $2.0 \%$ & $0.57[0.35,0.92]$ & . & \\
\hline Berruti D 2002 & 78 & 92 & 81 & 93 & -2.06 & 39.98 & $4.8 \%$ & $0.95[0.70,1.29]$ & & \\
\hline Ejlertsen B 2004 & 141 & 193 & 155 & 194 & -20.78 & 79.13 & $9.6 \%$ & $0.77[0.62,0.96]$ & & \\
\hline French Epi (A) 1991 & 110 & 135 & 56 & 70 & -1.68 & 60.31 & $7.3 \%$ & $0.97[0.76,1.25]$ & & \\
\hline French Epi (B) 1991 & 105 & 137 & 56 & 70 & -10.13 & 55.83 & $6.8 \%$ & $0.83[0.64,1.08]$ & & \\
\hline Heidemann E 2004 & 63 & 89 & 71 & 87 & -8.58 & 29.9 & $3.6 \%$ & $0.75[0.52,1.07]$ & & \\
\hline Ingle J 1985 & 75 & 79 & 75 & 79 & 0.47 & 54.3 & $6.6 \%$ & $1.01[0.77,1.32]$ & & \\
\hline Ingle J 1989 & 79 & 90 & 90 & 95 & -20.92 & 54.49 & $6.6 \%$ & $0.68[0.52,0.89]$ & $\rightarrow$ & \\
\hline Joensuu H 1998 & 124 & 150 & 129 & 153 & -15.38 & 56.17 & $6.8 \%$ & $0.76[0.59,0.99]$ & & \\
\hline Nielsen D 2000 & 61 & 74 & 68 & 81 & -3.62 & 22.78 & $2.8 \%$ & $0.85[0.57,1.29]$ & & \\
\hline Nielson D 1990 & 59 & 67 & 69 & 76 & -3.57 & 41.35 & $5.0 \%$ & $0.92[0.68,1.24]$ & & \\
\hline Vaughn CB 1988 & 45 & 56 & 59 & 63 & -10.55 & 26.74 & $3.2 \%$ & $0.67[0.46,0.98]$ & & \\
\hline Subtotal $(95 \%$ CI) & & 1206 & & 1106 & & & $65.2 \%$ & $0.82[0.75,0.89]$ & & \\
\hline Total events: & 969 & & 944 & & & & & & & \\
\hline \multicolumn{11}{|c|}{ Heterogeneity: $\mathrm{Chi}^{2}=11.46, \mathrm{df}=11(\mathrm{P}=0.41) ; \mathrm{I}^{2}=4 \%$} \\
\hline \multicolumn{11}{|c|}{ Test for overall effect: $\mathrm{Z}=4.58(\mathrm{P}<0.00001)$} \\
\hline \multicolumn{11}{|c|}{ 2.3.2 Sub group B: Single alkylating agent versus alkylating agent + other } \\
\hline Takayama T(B) 2000 & 19 & 27 & 47 & 55 & -12.8 & 21.31 & $2.6 \%$ & $0.55[0.36,0.84]$ & $\rightarrow$ & \\
\hline Subtotal (95\% CI) & & 27 & & 55 & & & $2.6 \%$ & $0.55[0.36,0.84]$ & & \\
\hline Total events: & 19 & & 47 & & & & & & & \\
\hline \multicolumn{11}{|c|}{ Heterogeneity: Not applicable } \\
\hline \multicolumn{11}{|c|}{ Test for overall effect: $\mathrm{Z}=2.77(\mathrm{P}=0.006)$} \\
\hline \multicolumn{11}{|c|}{ 2.3.3 Sub group C: Single antimetabolite versus antimetaboloite + other } \\
\hline Takayama T(A) 2000 & 19 & 27 & 43 & 57 & -3.77 & 20.98 & $2.5 \%$ & $0.84[0.54,1.28]$ & & \\
\hline Subtotal $(95 \% \mathrm{CI})$ & & 27 & & 57 & & & $2.5 \%$ & $0.84[0.54,1.28]$ & & \\
\hline Total events: & 19 & & 43 & & & & & & & \\
\hline \multicolumn{11}{|c|}{ Heterogeneity: Not applicable } \\
\hline \multicolumn{11}{|c|}{ Test for overall effect: $\mathrm{Z}=0.82(\mathrm{P}=0.41)$} \\
\hline \multicolumn{11}{|c|}{ 2.3.4 Sub group D: Single taxane versus taxane + other } \\
\hline Albain KS 2004 & 180 & 267 & 197 & 262 & -38.69 & 104.65 & $12.7 \%$ & $0.69[0.57,0.84]$ & - & \\
\hline O'Shaughnessy J 2002 & 231 & 255 & 250 & 256 & -53.4 & 139.9 & $17.0 \%$ & $0.68[0.58,0.81]$ & - & \\
\hline Subtotal $(95 \% \mathrm{CI})$ & & 522 & & 518 & & & $29.7 \%$ & $0.69[0.61,0.78]$ & 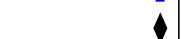 & \\
\hline Total events: & 411 & & 447 & & & & & & & \\
\hline \multicolumn{11}{|c|}{ Heterogeneity: $\mathrm{Chi}^{2}=0.01, \mathrm{df}=1(\mathrm{P}=0.93) ; \mathrm{I}^{2}=0 \%$} \\
\hline \multicolumn{11}{|c|}{ Test for overall effect: $\mathrm{Z}=5.89(\mathrm{P}<0.00001)$} \\
\hline Total (95\% CI) & & 1782 & & 1736 & & & $100.0 \%$ & $0.77[0.72,0.83]$ & 1 & \\
\hline Total events: & 1418 & & 1481 & & & & & & & \\
\hline \multicolumn{9}{|c|}{ Heterogeneity: $\mathrm{Chi}^{2}=19.51, \mathrm{df}=15(\mathrm{P}=0.19) ; \mathrm{I}^{2}=23 \%$} & $\begin{array}{cc} & 1 \\
0.05 & 0.2\end{array}$ & \\
\hline Test for overall effect: & $.48(\mathrm{P}<0 . \mathrm{C}$ & $0001)$ & & & & & & & ours combination & Favours singl \\
\hline
\end{tabular}


Analysis 2.4. Comparison 2: Time to progression, Outcome 4: Time to progression - Question 2 - Regimen A versus Regimen C - randomised patients

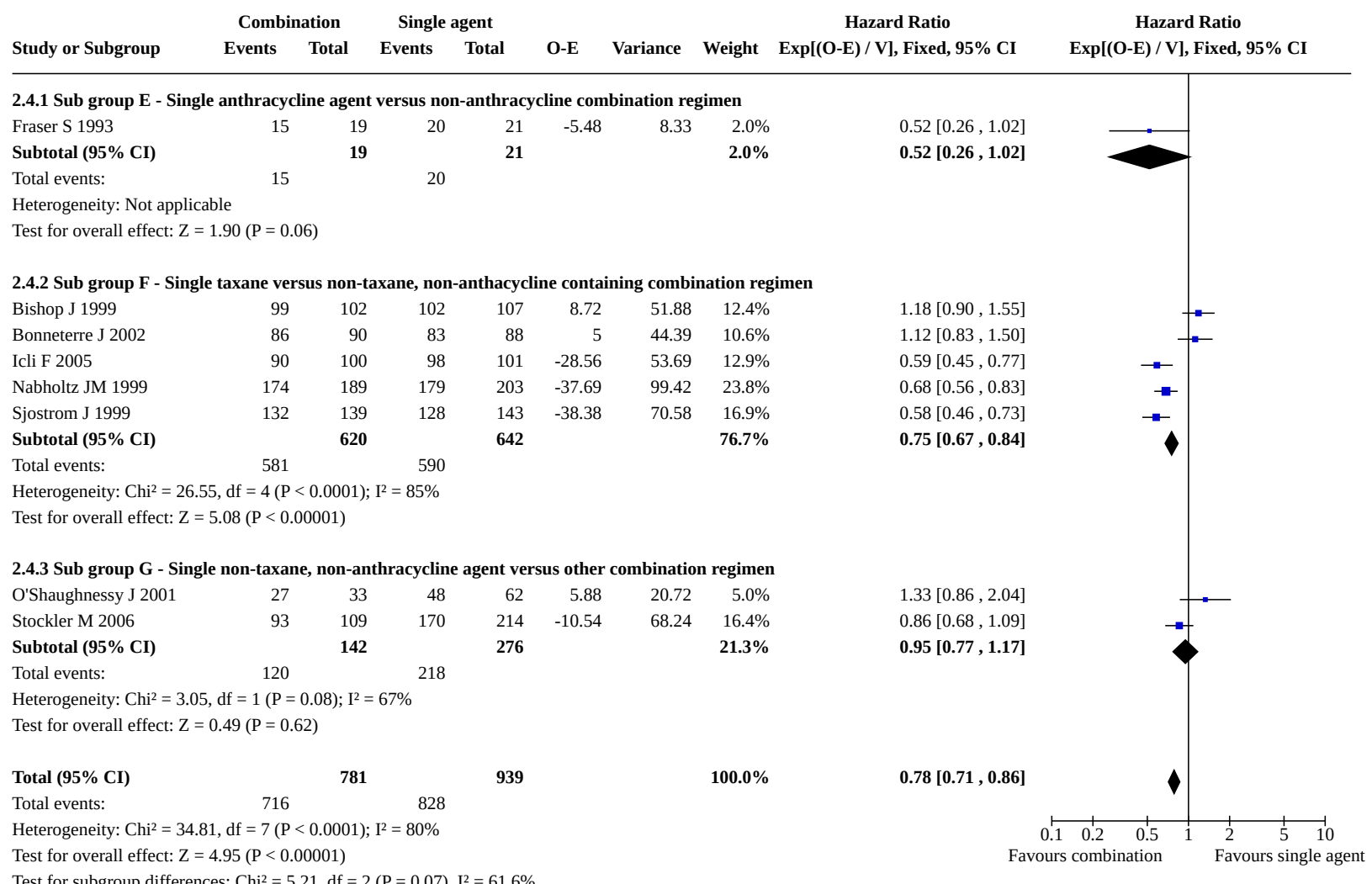

Analysis 2.5. Comparison 2: Time to progression, Outcome 5: Time to progression - single agent taxane versus all combinations

\begin{tabular}{|c|c|c|c|c|c|c|c|c|c|c|}
\hline \multirow[b]{2}{*}{ Study or Subgroup } & \multicolumn{2}{|c|}{ Combination } & \multicolumn{2}{|c|}{ Single agent } & \multirow[b]{2}{*}{ O-E } & \multirow[b]{2}{*}{ Variance } & \multirow[b]{2}{*}{ Weight } & Hazard Ratio & \multicolumn{2}{|c|}{ Hazard Ratio } \\
\hline & Events & Total & Events & Total & & & & $\operatorname{Exp}[($ O-E) / V], Fixed, 95\% CI & $\operatorname{Exp}[(\mathrm{O}-\mathrm{E}) / \mathrm{V}]$ & Fixed, 95\% CI \\
\hline Albain KS 2004 & 180 & 267 & 197 & 262 & -38.69 & 104.65 & $18.5 \%$ & $0.69[0.57,0.84]$ & $\rightarrow$ & \\
\hline Bishop J 1999 & 99 & 102 & 102 & 107 & 8.72 & 51.88 & $9.2 \%$ & $1.18[0.90,1.55]$ & & - \\
\hline Bonneterre J 2002 & 86 & 90 & 83 & 88 & 5 & 44.39 & $7.9 \%$ & $1.12[0.83,1.50]$ & & $=$ \\
\hline Icli F 2005 & 90 & 100 & 98 & 101 & -28.56 & 53.69 & $9.5 \%$ & $0.59[0.45,0.77]$ & $\rightarrow$ & \\
\hline Nabholtz JM 1999 & 174 & 189 & 179 & 203 & -37.69 & 99.42 & $17.6 \%$ & $0.68[0.56,0.83]$ & $\rightarrow$ & \\
\hline O'Shaughnessy J 2002 & 231 & 255 & 250 & 256 & -53.4 & 139.9 & $24.8 \%$ & $0.68[0.58,0.81]$ & - & \\
\hline Sjostrom J 1999 & 132 & 139 & 128 & 143 & -38.38 & 70.58 & $12.5 \%$ & $0.58[0.46,0.73]$ & $\rightarrow$ & \\
\hline Total $(95 \%$ CI) & & 1142 & & 1160 & & & $100.0 \%$ & $0.72[0.67,0.79]$ & 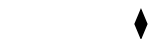 & \\
\hline Total events: & 992 & & 1037 & & & & & & & \\
\hline Heterogeneity: $\mathrm{Chi}^{2}=2$ & , df $=6(P$ & $=0.0001)$; & $\mathrm{I}^{2}=78 \%$ & & & & & & $\begin{array}{lll}1 & 0.2 & 0.5 \\
\end{array}$ & $\begin{array}{ll}1 & 5\end{array}$ \\
\hline Test for overall effect: $Z$ & $.70(\mathrm{P}<0$. & 0001) & & & & & & & Irs combination & Favours sing \\
\hline
\end{tabular}




\section{Analysis 2.6. Comparison 2: Time to progression, Outcome 6: Time} to progression - Single agent anthracycline versus all combinations

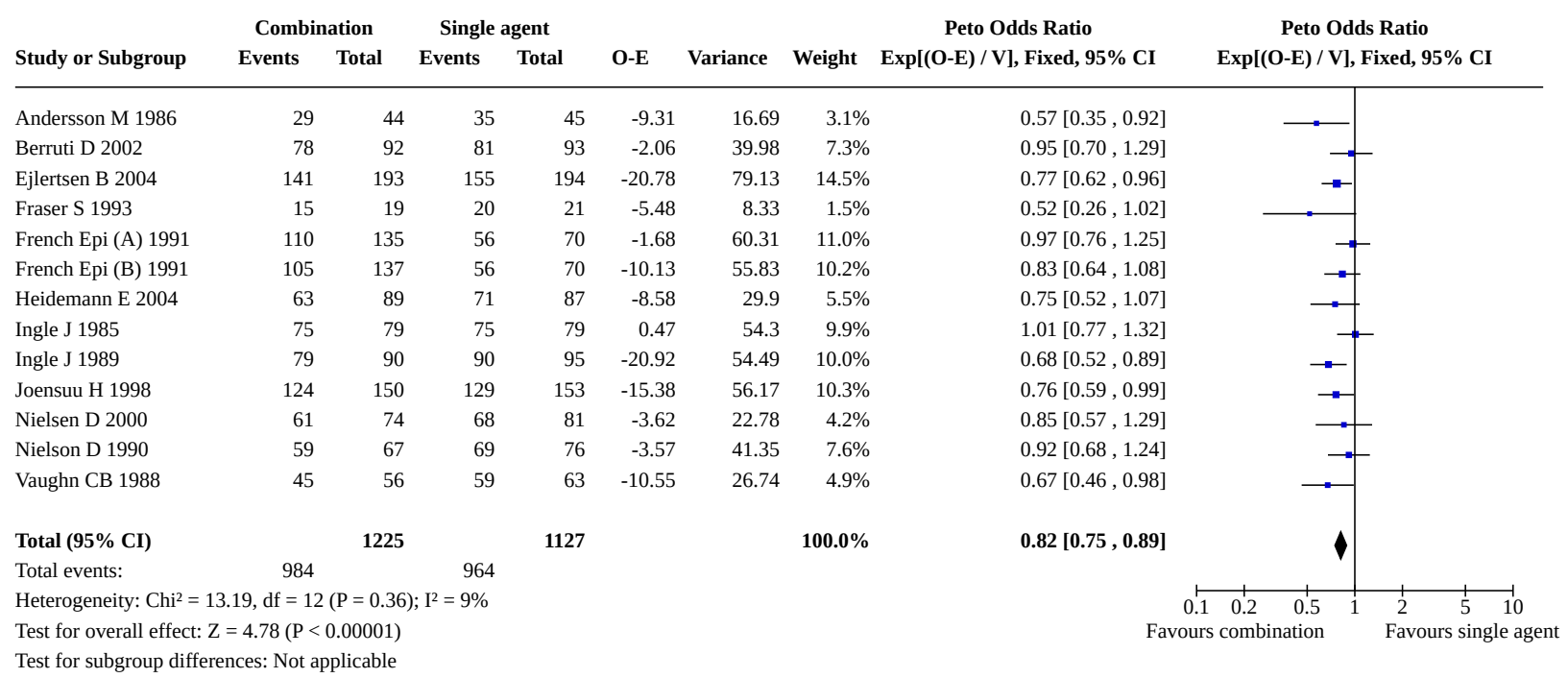

\section{Comparison 3. Overall response}

\begin{tabular}{|c|c|c|c|c|}
\hline Outcome or subgroup title & No. of studies & $\begin{array}{l}\text { No. of partici- } \\
\text { pants }\end{array}$ & Statistical method & Effect size \\
\hline $\begin{array}{l}3.1 \text { Overall response - assessable pa- } \\
\text { tients-all trials }\end{array}$ & 46 & 9044 & $\begin{array}{l}\text { Risk Ratio (M-H, Ran- } \\
\text { dom, } 95 \% \mathrm{Cl} \text { ) }\end{array}$ & $1.29[1.14,1.45]$ \\
\hline $\begin{array}{l}\text { 3.1.1 Question 1: Regimen A versus Regimen } \\
\text { A + Other }\end{array}$ & 29 & 6102 & $\begin{array}{l}\text { Risk Ratio (M-H, Ran- } \\
\text { dom, } 95 \% \mathrm{Cl})\end{array}$ & $1.37[1.20,1.56]$ \\
\hline $\begin{array}{l}\text { 3.1.2 Question 2: Regimen A versus Regimen } \\
\text { C (poly) }\end{array}$ & 17 & 2942 & $\begin{array}{l}\text { Risk Ratio (M-H, Ran- } \\
\text { dom, } 95 \% \mathrm{Cl} \text { ) }\end{array}$ & $1.13[0.87,1.47]$ \\
\hline $\begin{array}{l}3.2 \text { Overall response - assessable patients } \\
\text { first line }\end{array}$ & 25 & 4767 & $\begin{array}{l}\text { Risk Ratio (M-H, Ran- } \\
\text { dom, } 95 \% \mathrm{Cl} \text { ) }\end{array}$ & $1.35[1.16,1.56]$ \\
\hline $\begin{array}{l}\text { 3.2.1 Question 1: Regimen A versus Regimen } \\
\text { A + other }\end{array}$ & 17 & 3055 & $\begin{array}{l}\text { Risk Ratio (M-H, Ran- } \\
\text { dom, } 95 \% \mathrm{Cl} \text { ) }\end{array}$ & $1.38[1.14,1.66]$ \\
\hline $\begin{array}{l}\text { 3.2.2 Question 2: Regimen A versus Regimen } \\
\text { C (poly) }\end{array}$ & 8 & 1712 & $\begin{array}{l}\text { Risk Ratio (M-H, Ran- } \\
\text { dom, } 95 \% \mathrm{Cl} \text { ) }\end{array}$ & $1.31[1.01,1.69]$ \\
\hline $\begin{array}{l}3.3 \text { Overall response - Question } 1 \text { - Regimen } \\
\text { A versus } A+\text { other - assessable patients }\end{array}$ & 27 & 5125 & $\begin{array}{l}\text { Risk Ratio (M-H, Ran- } \\
\text { dom, } 95 \% \mathrm{Cl})\end{array}$ & $1.32[1.16,1.50]$ \\
\hline $\begin{array}{l}\text { 3.3.1 Sub group A: Single anthracycline } \\
\text { agent versus anthracycline + other regimen }\end{array}$ & 16 & 3084 & $\begin{array}{l}\text { Risk Ratio (M-H, Ran- } \\
\text { dom, } 95 \% \mathrm{Cl} \text { ) }\end{array}$ & $1.15[1.02,1.31]$ \\
\hline $\begin{array}{l}\text { 3.3.2 Sub group B: Single alkylating agent } \\
\text { versus alkylanting agent + other }\end{array}$ & 5 & 390 & $\begin{array}{l}\text { Risk Ratio (M-H, Ran- } \\
\text { dom, } 95 \% \mathrm{Cl})\end{array}$ & $1.60[0.96,2.67]$ \\
\hline $\begin{array}{l}\text { 3.3.3 Sub group C: Single antimetabolite ver- } \\
\text { sus antimetabolite + other }\end{array}$ & 3 & 275 & $\begin{array}{l}\text { Risk Ratio (M-H, Ran- } \\
\text { dom, } 95 \% \mathrm{Cl})\end{array}$ & $2.95[1.92,4.52]$ \\
\hline
\end{tabular}




\begin{tabular}{|c|c|c|c|c|}
\hline Outcome or subgroup title & No. of studies & $\begin{array}{l}\text { No. of partici- } \\
\text { pants }\end{array}$ & Statistical method & Effect size \\
\hline $\begin{array}{l}\text { 3.3.4 Sub group D: Single taxane versus tax- } \\
\text { ane + other }\end{array}$ & 3 & 1376 & $\begin{array}{l}\text { Risk Ratio (M-H, Ran- } \\
\text { dom, } 95 \% \mathrm{Cl} \text { ) }\end{array}$ & $1.52[1.26,1.83]$ \\
\hline $\begin{array}{l}\text { 3.4 Overall response - Question } 2 \text { - Regimen } \\
\text { A versus Regimen C - assessable patients }\end{array}$ & 16 & 2713 & $\begin{array}{l}\text { Risk Ratio (M-H, Ran- } \\
\text { dom, } 95 \% \mathrm{Cl} \text { ) }\end{array}$ & $1.11[0.84,1.48]$ \\
\hline $\begin{array}{l}\text { 3.4.1 Sub group E - Single anthrycycline } \\
\text { agent versus non-anthrycycline combina- } \\
\text { tion regimen }\end{array}$ & 4 & 714 & $\begin{array}{l}\text { Risk Ratio (M-H, Ran- } \\
\text { dom, } 95 \% \mathrm{Cl} \text { ) }\end{array}$ & $1.42[1.15,1.76]$ \\
\hline $\begin{array}{l}\text { 3.4.2 Sub group F - Single taxane versus non- } \\
\text { taxane, non-anthrycycline containing com- } \\
\text { bination regimen }\end{array}$ & 5 & 1202 & $\begin{array}{l}\text { Risk Ratio (M-H, Ran- } \\
\text { dom, } 95 \% \mathrm{Cl} \text { ) }\end{array}$ & $0.80[0.48,1.33]$ \\
\hline $\begin{array}{l}\text { 3.4.3 Sub group G - Single non-taxane, non- } \\
\text { anthrycycline agent versus other combina- } \\
\text { tion regimen }\end{array}$ & 7 & 797 & $\begin{array}{l}\text { Risk Ratio (M-H, Ran- } \\
\text { dom, } 95 \% \mathrm{CI})\end{array}$ & $1.28[0.79,2.08]$ \\
\hline $\begin{array}{l}3.5 \text { Overall response - single agent taxane } \\
\text { versus all combinations }\end{array}$ & 8 & 2578 & $\begin{array}{l}\text { Risk Ratio (M-H, Ran- } \\
\text { dom, } 95 \% \mathrm{Cl} \text { ) }\end{array}$ & $1.03[0.72,1.48]$ \\
\hline $\begin{array}{l}\text { 3.6 Overall response - single agent anthracy- } \\
\text { cline versus all combinations }\end{array}$ & 20 & 3798 & $\begin{array}{l}\text { Risk Ratio (M-H, Ran- } \\
\text { dom, } 95 \% \mathrm{Cl} \text { ) }\end{array}$ & $1.19[1.06,1.34]$ \\
\hline
\end{tabular}


Analysis 3.1. Comparison 3: Overall response, Outcome 1: Overall response - assessable patients-all trials

\begin{tabular}{|c|c|c|c|c|c|c|c|c|}
\hline \multirow[b]{2}{*}{ Study or Subgroup } & \multicolumn{2}{|c|}{ Combination } & \multicolumn{2}{|c|}{ Single agent } & \multirow[b]{2}{*}{ Weight } & \multirow{2}{*}{$\begin{array}{c}\text { Risk Ratio } \\
\text { M-H, Random, 95\% CI }\end{array}$} & \multirow{2}{*}{\multicolumn{2}{|c|}{$\begin{array}{c}\text { Risk Ratio } \\
\text { M-H, Random, 95\% }\end{array}$}} \\
\hline & Events & Total & Events & Total & & & & \\
\hline \multicolumn{9}{|c|}{ 3.1.1 Question 1: Regimen A versus Regimen A + Other } \\
\hline Ahmann DL 1974(1) & 12 & 21 & 1 & 22 & $0.3 \%$ & $12.57[1.79,88.40]$ & & \\
\hline Albain KS 2004 & 107 & 262 & 57 & 259 & $2.8 \%$ & $1.86[1.41,2.43]$ & & $\longrightarrow$ \\
\hline Andersson M 1986 & 19 & 39 & 20 & 42 & $2.3 \%$ & $1.02[0.65,1.61]$ & & \\
\hline Berruti D 2002 & 53 & 92 & 47 & 93 & $2.9 \%$ & $1.14[0.87,1.49]$ & & \\
\hline Carmo-Pereira 1980 & 47 & 68 & 12 & 67 & $2.0 \%$ & $3.86[2.26,6.60]$ & & \\
\hline Ejlertsen B 2004 & 96 & 193 & 81 & 194 & $3.0 \%$ & $1.19[0.96,1.48]$ & & $\rightarrow$ \\
\hline Falkson G 1990 & 19 & 52 & 17 & 51 & $2.0 \%$ & $1.10[0.65,1.86]$ & & \\
\hline French Epi (A) 1991 & 54 & 121 & 18 & 60 & $2.3 \%$ & $1.49[0.96,2.30]$ & & \\
\hline French Epi (B) 1991 & 55 & 123 & 17 & 61 & $2.3 \%$ & $1.60[1.02,2.51]$ & & \\
\hline GEICAM 2007 & 45 & 125 & 33 & 126 & $2.5 \%$ & $1.37[0.94,2.00]$ & & \\
\hline Gundersen S 1986 & 24 & 66 & 19 & 62 & $2.1 \%$ & $1.19[0.73,1.94]$ & & \\
\hline Heidemann E 2004 & 44 & 87 & 20 & 86 & $2.3 \%$ & $2.17[1.41,3.36]$ & & \\
\hline Ingle J 1985 & 25 & 77 & 26 & 74 & $2.3 \%$ & $0.92[0.59,1.44]$ & & \\
\hline Ingle J 1989 & 39 & 90 & 24 & 95 & $2.4 \%$ & $1.72[1.13,2.61]$ & & $\longrightarrow$ \\
\hline Joensuu H 1998 & 67 & 143 & 79 & 140 & $3.0 \%$ & $0.83[0.66,1.04]$ & & \\
\hline Mouridsen HT 1977 & 17 & 27 & 6 & 24 & $1.5 \%$ & $2.52[1.19,5.34]$ & & \\
\hline Nielsen D 2000 & 43 & 65 & 45 & 74 & $2.9 \%$ & $1.09[0.85,1.40]$ & & \\
\hline Nielson D 1990 & 28 & 67 & 38 & 76 & $2.6 \%$ & $0.84[0.58,1.20]$ & & - \\
\hline Norris B 2000 & 55 & 145 & 44 & 144 & $2.7 \%$ & $1.24[0.90,1.71]$ & & \\
\hline O'Shaughnessy J 2002 & 107 & 255 & 77 & 256 & $2.9 \%$ & $1.40[1.10,1.77]$ & & \\
\hline Rubens RD 1975 & 32 & 50 & 29 & 49 & $2.7 \%$ & $1.08[0.79,1.48]$ & & \\
\hline Sledge G(A) 2003 & 54 & 115 & 81 & 224 & $2.9 \%$ & $1.30[1.00,1.69]$ & & \\
\hline Sledge G(B) 2003 & 54 & 115 & 78 & 229 & $2.9 \%$ & $1.38[1.06,1.80]$ & & $\rightarrow$ \\
\hline Steiner R 1983 & 28 & 54 & 30 & 53 & $2.6 \%$ & $0.92[0.65,1.30]$ & & - \\
\hline Takayama T(A) 2000 & 10 & 27 & 8 & 57 & $1.3 \%$ & $2.64[1.17,5.93]$ & & \\
\hline Takayama T(B) 2000 & 10 & 27 & 13 & 55 & $1.6 \%$ & $1.57[0.79,3.10]$ & & \\
\hline Tashiro H 1994 & 11 & 28 & 6 & 28 & $1.3 \%$ & $1.83[0.79,4.27]$ & & \\
\hline Thomas E 2008 & 130 & 375 & 54 & 377 & $2.8 \%$ & $2.42[1.82,3.21]$ & & $\rightarrow$ \\
\hline Vaughn CB 1988 & 13 & 56 & 14 & 59 & $1.7 \%$ & $0.98[0.51,1.89]$ & & \\
\hline Subtotal (95\% CI) & & 2965 & & 3137 & $66.8 \%$ & $1.37[1.20,1.56]$ & & \\
\hline Total events: & 1298 & & 994 & & & & & \\
\hline \multicolumn{9}{|c|}{ Heterogeneity: $\mathrm{Tau}^{2}=0.08 ; \mathrm{Chi}^{2}=99.40, \mathrm{df}=28(\mathrm{P}<0.00001) ; \mathrm{I}^{2}=72 \%$} \\
\hline \multicolumn{9}{|c|}{ Test for overall effect: $\mathrm{Z}=4.70(\mathrm{P}<0.00001)$} \\
\hline \multicolumn{9}{|c|}{ 3.1.2 Question 2: Regimen A versus Regimen C (poly) } \\
\hline ANZBCTG 2001 & 70 & 190 & 47 & 192 & $2.7 \%$ & $1.51[1.10,2.05]$ & & $\because$ \\
\hline Bishop J 1999 & 36 & 102 & 31 & 107 & $2.4 \%$ & $1.22[0.82,1.81]$ & & \\
\hline Bonneterre J 2002 & 35 & 90 & 37 & 86 & $2.6 \%$ & $0.90[0.63,1.29]$ & & \\
\hline Canellos GP 1976 & 49 & 93 & 18 & 91 & $2.3 \%$ & $2.66[1.69,4.20]$ & & \\
\hline Eagan RT 1976 & 4 & 20 & 2 & 19 & $0.5 \%$ & $1.90[0.39,9.20]$ & & \\
\hline Erkisi M 1997 & 12 & 30 & 16 & 30 & $2.0 \%$ & $0.75[0.43,1.30]$ & & - \\
\hline Fraser S 1993 & 11 & 19 & 6 & 21 & $1.4 \%$ & $2.03[0.93,4.41]$ & & \\
\hline Heidemann E 2002 & 43 & 119 & 30 & 119 & $2.5 \%$ & $1.43[0.97,2.12]$ & & \\
\hline Hoogstraten B(A)1976 & 39 & 98 & 15 & 39 & $2.2 \%$ & $1.03[0.65,1.65]$ & & \\
\hline Hoogstraten B(B)1976 & 63 & 106 & 16 & 40 & $2.4 \%$ & $1.49[0.99,2.24]$ & & $\longrightarrow$ \\
\hline Icli F 2005 & 33 & 91 & 21 & 94 & $2.2 \%$ & $1.62[1.02,2.58]$ & & - \\
\hline Nabholtz JM 1999 & 21 & 171 & 60 & 179 & $2.3 \%$ & $0.37[0.23,0.57]$ & & \\
\hline O'Shaughnessy J 2001 & 18 & 61 & 5 & 32 & $1.2 \%$ & $1.89[0.77,4.62]$ & & \\
\hline Sjostrom J 1999 & 29 & 139 & 61 & 143 & $2.5 \%$ & $0.49[0.34,0.71]$ & & \\
\hline Stockler M 2006 & 18 & 109 & 42 & 214 & $2.1 \%$ & $0.84[0.51,1.39]$ & & - \\
\hline Venturino A(A) 2000 & 10 & 33 & 4 & 17 & $1.0 \%$ & $1.29[0.47,3.50]$ & & \\
\hline Venturino A (B) 2000 & 7 & 32 & 4 & 16 & $0.9 \%$ & $0.88[0.30,2.56]$ & & \\
\hline Subtotal (95\% CI) & & 1503 & & 1439 & $33.2 \%$ & $1.13[0.87,1.47]$ & & \\
\hline Total events: & 498 & & 415 & & & & & \\
\hline
\end{tabular}


Analysis 3.1. (Continued)

Total events:

498

415

Heterogeneity: $\mathrm{Tau}^{2}=0.22 ; \mathrm{Chi}^{2}=74.69, \mathrm{df}=16(\mathrm{P}<0.00001) ; \mathrm{I}^{2}=79 \%$

Test for overall effect: $\mathrm{Z}=0.90(\mathrm{P}=0.37)$

Total $(95 \% \mathrm{CI})$

4468

Total events:

1796 1409

Heterogeneity: Tau $^{2}=0.11 ; \mathrm{Chi}^{2}=177.93, \mathrm{df}=45(\mathrm{P}<0.00001) ; \mathrm{I}^{2}=75 \%$

Test for overall effect: $\mathrm{Z}=4.10(\mathrm{P}<0.0001)$

Test for subgroup differences: $\mathrm{Chi}^{2}=1.64, \mathrm{df}=1(\mathrm{P}=0.20), \mathrm{I}^{2}=39.1 \%$

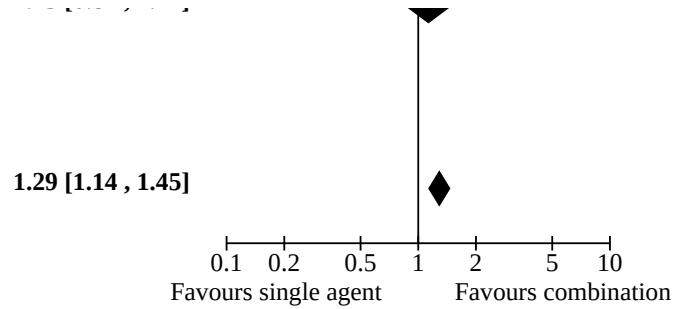

Analysis 3.2. Comparison 3: Overall response, Outcome 2: Overall response - assessable patients first line

\begin{tabular}{|c|c|c|c|c|c|c|c|}
\hline \multirow[b]{2}{*}{ Study or Subgroup } & \multicolumn{2}{|c|}{ Combination } & \multicolumn{2}{|c|}{ Single agent } & \multicolumn{2}{|r|}{ Risk Ratio } & \multirow{2}{*}{$\begin{array}{c}\text { Risk Ratio } \\
\text { M-H, Random, 95\% CI }\end{array}$} \\
\hline & Events & Total & Events & Total & Weight & M-H, Random, 95\% CI & \\
\hline
\end{tabular}

3.2.1 Question 1: Regimen A versus Regimen A + other

$\begin{array}{llllll}\text { Ahmann DL 1974(1) } & 12 & 21 & 1 & 22 & 0.5 \%\end{array}$

Albain KS $2004 \quad 107 \quad 262 \quad 57 \quad 259 \quad 5.1 \%$

$\begin{array}{llllll}\text { Berruti D } 2002 & 53 & 92 & 47 & 93 & 5.1 \%\end{array}$

$\begin{array}{llllll}\text { Carmo-Pereira } 1980 & 47 & 68 & 12 & 67 & 3.4 \%\end{array}$

$\begin{array}{llllll}\text { Ejlertsen B } 2004 & 96 & 193 & 81 & 194 & 5.4 \%\end{array}$

$\begin{array}{llllll}\text { Falkson G } 1990 & 19 & 52 & 17 & 51 & 3.5 \%\end{array}$

French Epi (A) 1991

French Epi (B) 1991

$121 \quad 18 \quad 60 \quad 4.0 \%$

Gundersen S 1986

$54 \quad 121$

$\begin{array}{ll}60 & 4.0 \% \\ 61 & 3.9 \%\end{array}$

$3.9 \%$
$3.7 \%$

Heidemann E 2004

Ingle J 1985

Ingle J 1989

Joensuu H 1998

Mouridsen HT 1977

Nielsen D 2000

Rubens RD 1975

Steiner R 1983

Subtotal (95\% CI)

66

19

$62 \quad 3.7 \%$

$4.0 \%$
$3.9 \%$

$4.1 \%$

$5.4 \%$

$2.4 \%$

$5.2 \%$

Total events:

528

12.57 [1.79, 88.40]

$1.86[1.41,2.43]$

1.14 [0.87, 1.49]

$3.86[2.26,6.60]$

1.19 [0.96, 1.48$]$

$1.10[0.65,1.86]$

$1.49[0.96,2.30]$

1.60 [1.02, 2.51]

$1.19[0.73,1.94]$

$2.17[1.41,3.36]$

$0.92[0.59,1.44]$

$1.72[1.13,2.61]$

0.83 [0.66, 1.04]

$2.52[1.19,5.34]$

$1.09[0.85,1.40]$

$1.08[0.79,1.48]$

$0.92[0.65,1.30]$

$1.38[1.14,1.66]$

M-H, Random, 95\% CI

Heterogeneity: $\mathrm{Tau}^{2}=0.10 ; \mathrm{Chi}^{2}=67.39, \mathrm{df}=16(\mathrm{P}<0.00001) ; \mathrm{I}^{2}=76 \%$

Test for overall effect: $\mathrm{Z}=3.37(\mathrm{P}=0.0008)$

3.2.2 Question 2: Regimen A versus Regimen C (poly)

ANZBCTG 200

Bishop J 1999

Canellos GP 1976

Heidemann E 2002

$\begin{array}{rr}70 & 190 \\ 36 & 102 \\ 49 & 93 \\ 43 & 119 \\ 39 & 98 \\ 63 & 106 \\ 5 & 32 \\ 18 & 109 \\ & \mathbf{8 4 9}\end{array}$

47

192

$107 \quad 4.3 \%$

Hoogstraten B(A)1976

Hoogstraten B(B)1976

O'Shaughnessy J 2001

Stockler M 2006

Subtotal (95\% CI)

323

849

Total events:

Heterogeneity: $\mathrm{Tau}^{2}=0.08 ; \mathrm{Chi}^{2}=18.41, \mathrm{df}=7(\mathrm{P}=0.01) ; \mathrm{I}^{2}=62 \%$

Test for overall effect: $\mathrm{Z}=2.06(\mathrm{P}=0.04)$

Total (95\% CI)

2440

$2327 \quad 100.0 \%$

Total events:

1085 745

Heterogeneity: $\mathrm{Tau}^{2}=0.09 ; \mathrm{Chi}^{2}=86.05, \mathrm{df}=24(\mathrm{P}<0.00001) ; \mathrm{I}^{2}=72 \%$

Test for overall effect: $\mathrm{Z}=3.96(\mathrm{P}<0.0001)$

Test for subgroup differences: $\mathrm{Chi}^{2}=0.10, \mathrm{df}=1(\mathrm{P}=0.75), \mathrm{I}^{2}=0 \%$
$4.3 \%$
$3.9 \%$

$1.51[1.10,2.05]$

$1.22[0.82,1.81]$

$2.66[1.69,4.20]$

$1.43[0.97,2.12]$

$1.03[0.65,1.65]$

1.49 [0.99, 2.24]

$0.84[0.51,1.39]$

1.31 [1.01, 1.69]

$30.8 \%$
$0.53[0.22,1.29]$

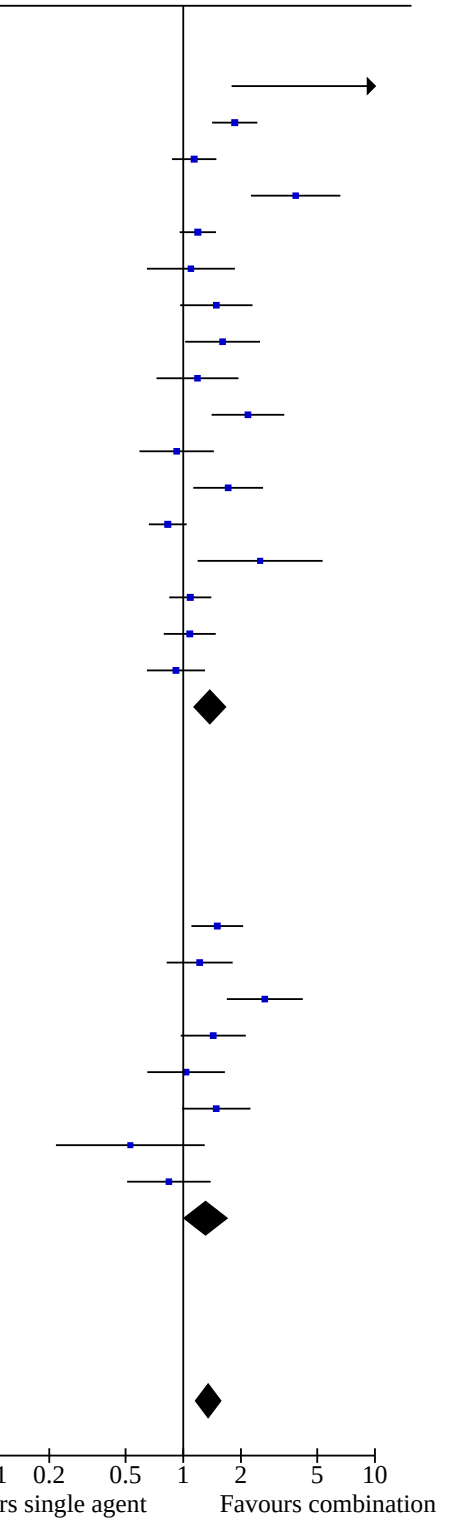

Single agent versus combination chemotherapy for metastatic breast cancer (Review) 
Analysis 3.3. Comparison 3: Overall response, Outcome 3: Overall response - Question 1 - Regimen A versus A + other - assessable patients

\begin{tabular}{|c|c|c|c|c|c|c|c|}
\hline \multirow[b]{2}{*}{ Study or Subgroup } & \multicolumn{2}{|c|}{ Combination } & \multicolumn{2}{|c|}{ Single agent } & \multicolumn{2}{|r|}{ Risk Ratio } & Risk Ratio \\
\hline & Events & Total & Events & Total & Weight & M-H, Random, 95\% CI & M-H, Random, 95\% CI \\
\hline
\end{tabular}

3.3.1 Sub group A: Single anthracycline agent versus anthracycline + other regimen

Andersson M 1986

Berruti D 2002

Ejlertsen B 2004

French Epi (A) 1991

French Epi (B) 1991

Gundersen S 1986

Heidemann E 2004

Ingle J 1985

Ingle J 1989

Joensuu H 1998

Nielsen D 2000

Nielson D 1990

Norris B 2000

Sledge G(A) 2003

Steiner R 1983

Vaughn CB 1988

Subtotal (95\% CI)

Total events:

Heterogeneity: $\mathrm{Tau}^{2}=0.03 ; \mathrm{Chi}^{2}=31.87, \mathrm{df}=15(\mathrm{P}=0.007) ; \mathrm{I}^{2}=53 \%$

Test for overall effect: $\mathrm{Z}=2.21(\mathrm{P}=0.03)$

3.3.2 Sub group B: Single alkylating agent versus alkylanting agent + other $\begin{array}{llllll}\text { Ahmann DL 1974(1) } & 12 & 21 & 1 & 22 & 0.4 \%\end{array}$ $\begin{array}{llllll}\text { Falkson G } 1990 & 19 & 57 & 17 & 54 & 3.0 \%\end{array}$ $\begin{array}{llllll}\text { Mouridsen HT } 1977 & 17 & 28 & 6 & 27 & 2.0 \%\end{array}$ $\begin{array}{llllll}\text { Rubens RD } 1975 & 32 & 50 & 29 & 49 & 4.6 \%\end{array}$

Takayama T(B) 2000

$10 \quad 27$

183

$55 \quad 2.3 \%$

Subtotal (95\% CI)

90

$207 \quad 12.3 \%$

Total events: 66

Heterogeneity: $\mathrm{Tau}^{2}=0.21 ; \mathrm{Chi}^{2}=12.53, \mathrm{df}=4(\mathrm{P}=0.01) ; \mathrm{I}^{2}=68 \%$

Test for overall effect: $\mathrm{Z}=1.79(\mathrm{P}=0.07)$

3.3.3 Sub group C: Single antimetabolite versus antimetabolite + other

$\begin{array}{llrrrr}\text { Carmo-Pereira 1980 } & 47 & 68 & 12 & 67 & 3.0 \% \\ \text { Takayama T(A) } 2000 & 10 & 27 & 8 & 57 & 1.8 \% \\ \text { Tashiro H 1994 } & 11 & 28 & 6 & 28 & 1.7 \%\end{array}$

Subtotal (95\% CI)

1128

123

$6 \quad 28$

$1.7 \%$

Total events:

68

26

Heterogeneity: $\mathrm{Tau}^{2}=0.02 ; \mathrm{Chi}^{2}=2.26, \mathrm{df}=2(\mathrm{P}=0.32) ; \mathrm{I}^{2}=11 \%$

Test for overall effect: $\mathrm{Z}=4.96(\mathrm{P}<0.00001)$

3.3.4 Sub group D: Single taxane versus taxane + other

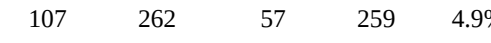

$\begin{array}{llllll}\text { O'Shaughnessy J } 2002 & 107 & 255 & 77 & 256 & 5.2 \%\end{array}$

Sledge G(B) 2003

$54 \quad 115$

632

78

$229 \quad 5.0 \%$

Subtotal (95\% CI)

268

212

Heterogeneity: $\mathrm{Tau}^{2}=0.01 ; \mathrm{Chi}^{2}=3.13, \mathrm{df}=2(\mathrm{P}=0.21) ; \mathrm{I}^{2}=36 \%$

Test for overall effect: $\mathrm{Z}=4.41(\mathrm{P}<0.0001)$

Total (95\% CI)

2482

Total events:

1123

907

Heterogeneity: $\mathrm{Tau}^{2}=0.07 ; \mathrm{Chi}^{2}=81.38, \mathrm{df}=26(\mathrm{P}<0.00001) ; \mathrm{I}^{2}=68 \%$

Test for overall effect: $\mathrm{Z}=4.18(\mathrm{P}<0.0001)$

Test for suhornoun differences: $C . \mathrm{hi}^{2}=70.60 . \mathrm{df}=3(\mathrm{P}=0.0001) . \mathrm{I}^{2}=8.4 \%$
$0.97[0.61,1.56]$

$1.14[0.87,1.49]$

$1.19[0.96,1.48]$

$1.49[0.96,2.30]$

$1.60[1.02,2.51]$

$1.19[0.73,1.94]$

$2.17[1.41,3.36]$

$0.92[0.59,1.44]$

$1.72[1.13,2.61]$

$0.83[0.66,1.04]$

$1.00[0.77,1.29]$

$0.84[0.58,1.20]$

$1.24[0.90,1.71]$

$1.30[1.00,1.69]$

$0.92[0.65,1.30]$

$0.98[0.51,1.89]$

$1.15[1.02,1.31]$

12.57 [1.79, 88.40]

$1.06[0.62,1.81]$

$2.73[1.27,5.88]$

$1.08[0.79,1.48]$

$1.57[0.79,3.10]$

$1.60[0.96,2.67]$

-H, Random, 95\% CI 


\section{Analysis 3.3. (Continued)}

Test for overall effect: $\mathrm{Z}=4.18(\mathrm{P}<0.0001)$

Test for subgroup differences: $\mathrm{Chi}^{2}=20.60, \mathrm{df}=3(\mathrm{P}=0.0001), \mathrm{I}^{2}=85.4 \%$

Favours single agent $\quad$ Favours combination

Analysis 3.4. Comparison 3: Overall response, Outcome 4: Overall response - Question 2 - Regimen A versus Regimen C - assessable patients

\begin{tabular}{lccccccc} 
& \multicolumn{2}{c}{ Combination } & \multicolumn{2}{c}{ Single agent } & & Risk Ratio & Risk Ratio \\
Study or Subgroup & Events & Total & Events & Total & Weight & M-H, Random, 95\% CI & M-H, Random, 95\% CI
\end{tabular}

3.4.1 Sub group E - Single anthrycycline agent versus non-anthrycycline combination regimen ANZBCTG 2001

Fraser S 1993

$70 \quad 194$

\section{7}

197

$7.9 \%$

$5.3 \%$

Hoogstraten B(A)1976

Hoogstraten B(B)1976

Subtotal (95\% CI)

Total events:

Heterogeneity: $\mathrm{Tau}^{2}=0.00 ; \mathrm{Chi}^{2}=2.78, \mathrm{df}=3(\mathrm{P}=0.43) ; \mathrm{I}^{2}=0 \%$

Test for overall effect: $\mathrm{Z}=3.28(\mathrm{P}=0.001)$

3.4.2 Sub group F - Single taxane versus non-taxane, non-anthrycycline containing combination regimen Bishop J 1999

Bonneterre J 2002

Icli F 2005

Nabholtz JM 1999

Sjostrom J 1999

Subtotal (95\% CI)

$\begin{array}{rr}36 & 102 \\ 35 & 90 \\ 33 & 91 \\ 21 & 171 \\ 29 & 139 \\ & \mathbf{5 9 3}\end{array}$

$\begin{array}{rrr}31 & 107 & 7.4 \% \\ 37 & 86 & 7.7 \% \\ 21 & 94 & 7.1 \% \\ 60 & 179 & 7.1 \% \\ 61 & 143 & 7.6 \% \\ & \mathbf{6 0 9} & \mathbf{3 6 . 9 \%}\end{array}$

$1.22[0.82,1.81]$

$0.90[0.63,1.29]$

$1.62[1.02,2.58]$

$0.37[0.23,0.57]$

$0.49[0.34,0.71]$

$0.80[0.48,1.33]$

Total events:

Heterogeneity: $\mathrm{Tau}^{2}=0.30 ; \mathrm{Chi}^{2}=32.11, \mathrm{df}=4(\mathrm{P}<0.00001) ; \mathrm{I}^{2}=88 \%$

Test for overall effect: $\mathrm{Z}=0.88(\mathrm{P}=0.38)$

3.4.3 Sub group G - Single non-taxane, non-anthrycycline agent versus other combination regimen Canellos GP 1976

$49 \quad 93$

Eagan RT 1976

Erkisi M 1997

O'Shaughnessy J 2001

Stockler M 2006

Venturino A(A) 2000

Venturino A (B) 2000

Subtotal (95\% CI)

420

$93 \quad 18$

91

$91 \quad 7.1 \%$

$19 \quad 2.4 \%$

$2.66[1.69,4.20]$

$12 \quad 30$

16

$1.90[0.39,9.20]$

$\begin{array}{lllll}18 & 61 & 5 & 32 & 4.7 \%\end{array}$

$0.75[0.43,1.30]$

$1.89[0.77,4.62]$

$0.84[0.51,1.39]$

$1.29[0.47,3.50]$

$0.88[0.30,2.56]$

Total events:

$\begin{array}{rr}10 & 33 \\ 7 & 32\end{array}$

214

$6.8 \%$

$4.2 \%$

378

$16 \quad 3.9 \%$

$1.28[0.79,2.08]$

Heterogeneity: $\mathrm{Tau}^{2}=0.25 ; \mathrm{Chi}^{2}=17.72, \mathrm{df}=6(\mathrm{P}=0.007) ; \mathrm{I}^{2}=66 \%$

Test for overall effect: $\mathrm{Z}=1.02(\mathrm{P}=0.31)$

Total (95\% CI)

1388

$1325 \quad 100.0 \%$

Total events:

455 385

Heterogeneity: $\mathrm{Tau}^{2}=0.24 ; \mathrm{Chi}^{2}=72.84, \mathrm{df}=15(\mathrm{P}<0.00001) ; \mathrm{I}^{2}=79 \%$

Test for overall effect: $\mathrm{Z}=0.73(\mathrm{P}=0.46)$

Test for subgroup differences: $\mathrm{Chi}^{2}=4.23, \mathrm{df}=2(\mathrm{P}=0.12), \mathrm{I}^{2}=52.8 \%$

M-H, Random, 95\% CI 
Analysis 3.5. Comparison 3: Overall response, Outcome 5: Overall response - single agent taxane versus all combinations

\begin{tabular}{lccccccc} 
& \multicolumn{2}{c}{ Combination } & \multicolumn{2}{c}{ Single agent } & \multicolumn{2}{c}{ Risk Ratio } & Risk Ratio \\
Study or Subgroup & Events & Total & Events & Total & Weight & M-H, Random, 95\% CI & M-H, Random, 95\% CI
\end{tabular}

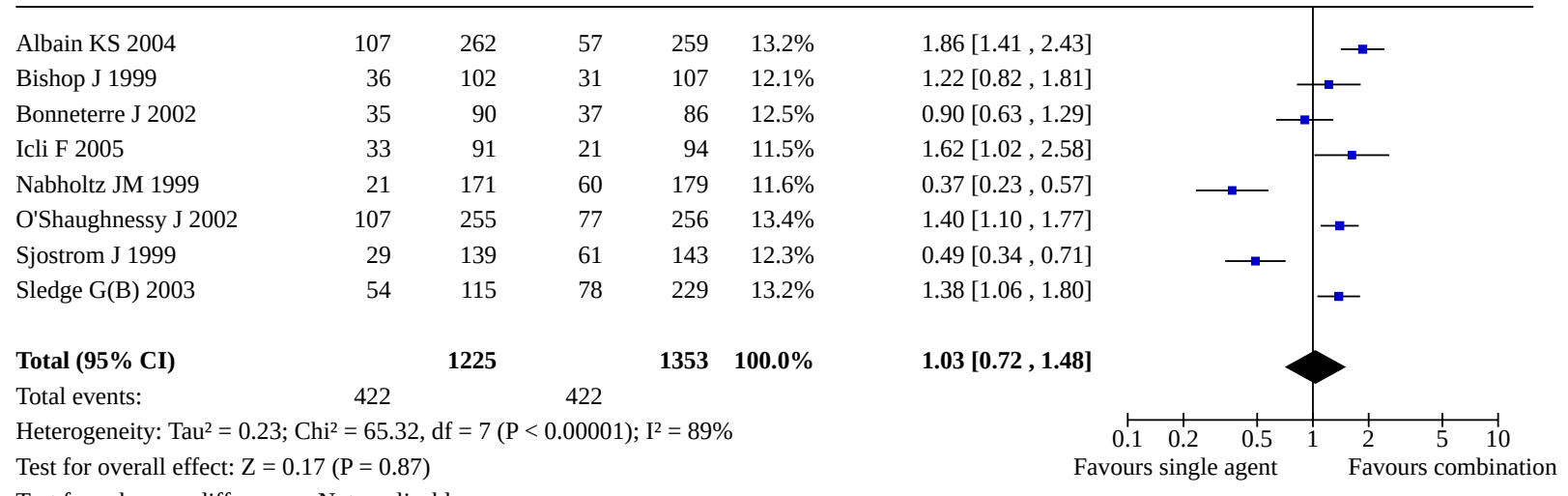

Test for subgroup differences: Not applicable

\section{Analysis 3.6. Comparison 3: Overall response, Outcome 6: Overall response - single agent anthracycline versus all combinations}

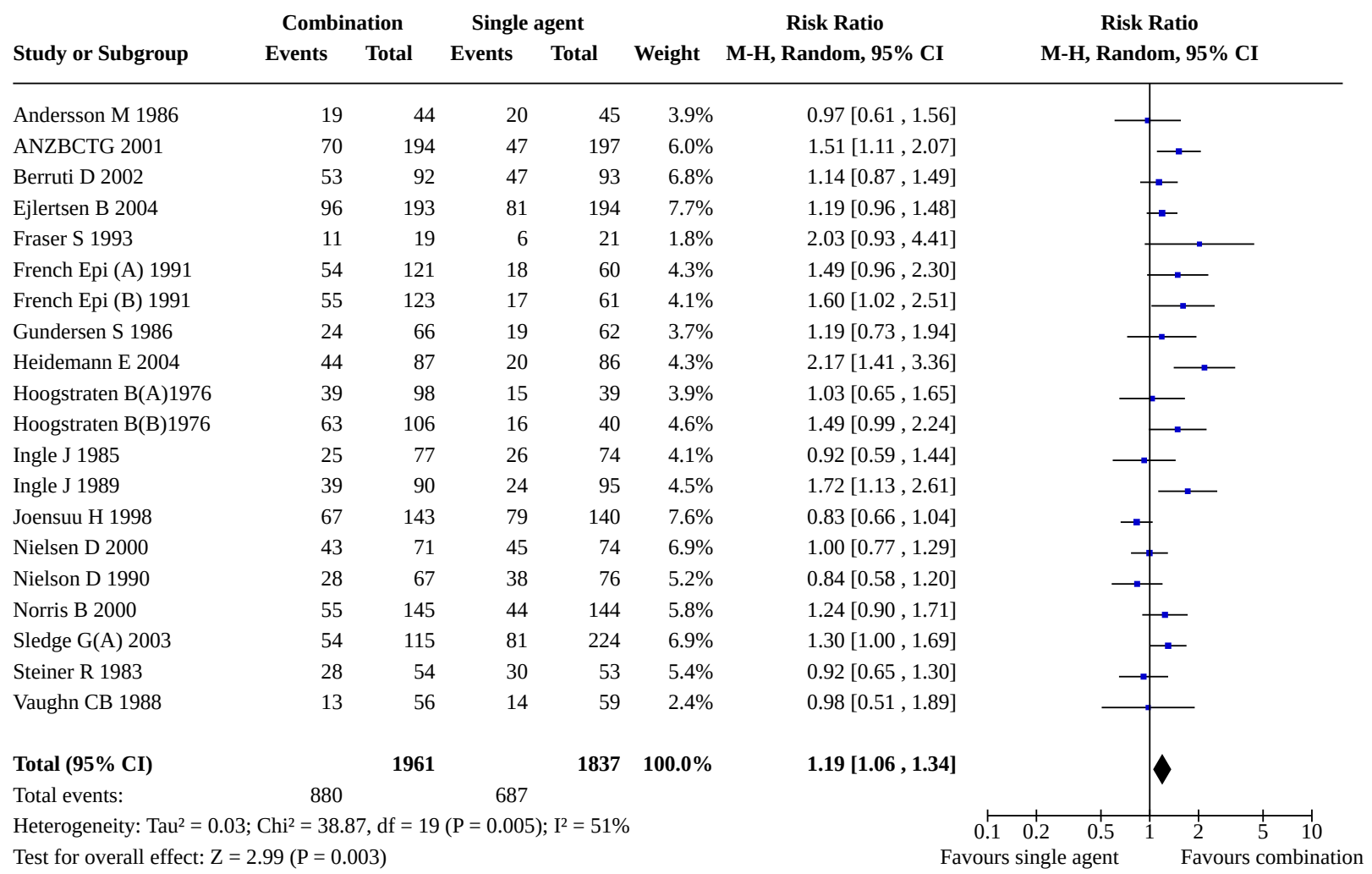


Comparison 4. Toxicity - Nausea and vomiting

\begin{tabular}{|c|c|c|c|c|}
\hline Outcome or subgroup title & No. of studies & $\begin{array}{l}\text { No. of partici- } \\
\text { pants }\end{array}$ & Statistical method & Effect size \\
\hline $\begin{array}{l}\text { 4.1 Nausea and vomiting - asssessable pa- } \\
\text { tients - all trials }\end{array}$ & 30 & 7487 & $\begin{array}{l}\text { Risk Ratio (M-H, Ran- } \\
\text { dom, } 95 \% \mathrm{Cl} \text { ) }\end{array}$ & $1.29[0.96,1.74]$ \\
\hline 4.1.1 Question 1: Regimen A versus A + other & 20 & 5149 & $\begin{array}{l}\text { Risk Ratio (M-H, Ran- } \\
\text { dom, } 95 \% \mathrm{Cl} \text { ) }\end{array}$ & $1.16[0.81,1.65]$ \\
\hline $\begin{array}{l}\text { 4.1.2 Question 2: Regimen A versus Regimen } \\
\text { C (poly) }\end{array}$ & 10 & 2338 & $\begin{array}{l}\text { Risk Ratio (M-H, Ran- } \\
\text { dom, } 95 \% \mathrm{Cl} \text { ) }\end{array}$ & $1.79[0.93,3.43]$ \\
\hline $\begin{array}{l}\text { 4.2 Nausea and vomiting - Question } 1 \text { - Regi- } \\
\text { men A versus A + other - assessable patients }\end{array}$ & 17 & 4793 & $\begin{array}{l}\text { Risk Ratio (M-H, Ran- } \\
\text { dom, } 95 \% \mathrm{Cl} \text { ) }\end{array}$ & $1.16[0.75,1.80]$ \\
\hline $\begin{array}{l}\text { 4.2.1 Sub-group A: Single antracycline agent } \\
\text { versus anthracycline + other regimen }\end{array}$ & 12 & 2958 & $\begin{array}{l}\text { Risk Ratio (M-H, Ran- } \\
\text { dom, } 95 \% \mathrm{Cl} \text { ) }\end{array}$ & $1.23[0.74,2.05]$ \\
\hline $\begin{array}{l}\text { 4.2.2 Sub group B: Single alkylating versus } \\
\text { alkylating + other }\end{array}$ & 1 & 103 & $\begin{array}{l}\text { Risk Ratio (M-H, Ran- } \\
\text { dom, } 95 \% \mathrm{Cl} \text { ) }\end{array}$ & $2.94[0.62,13.90]$ \\
\hline $\begin{array}{l}\text { 4.2.3 Sub group C: Single antimetabolite ver- } \\
\text { sus antimetabolite + other }\end{array}$ & 2 & 246 & $\begin{array}{l}\text { Risk Ratio (M-H, Ran- } \\
\text { dom, } 95 \% \mathrm{Cl} \text { ) }\end{array}$ & $0.44[0.34,0.58]$ \\
\hline $\begin{array}{l}\text { 4.2.4 Sub group D: Single taxane versus tax- } \\
\text { ane + other }\end{array}$ & 3 & 1486 & $\begin{array}{l}\text { Risk Ratio (M-H, Ran- } \\
\text { dom, } 95 \% \mathrm{Cl} \text { ) }\end{array}$ & $1.29[0.63,2.65]$ \\
\hline $\begin{array}{l}\text { 4.3 Nausea and vomiting - Question } 2 \text { - Reg- } \\
\text { imen A versus Regimen C - assessable pa- } \\
\text { tients }\end{array}$ & 9 & 2082 & $\begin{array}{l}\text { Risk Ratio (M-H, Ran- } \\
\text { dom, } 95 \% \mathrm{Cl} \text { ) }\end{array}$ & $1.45[0.79,2.66]$ \\
\hline $\begin{array}{l}\text { 4.3.1 Sub group E: Single anthracycline } \\
\text { agent versus non-anthracycline combina- } \\
\text { tion regimen }\end{array}$ & 2 & 422 & $\begin{array}{l}\text { Risk Ratio (M-H, Ran- } \\
\text { dom, } 95 \% \mathrm{Cl} \text { ) }\end{array}$ & $\begin{array}{l}3.44[0.11 \\
104.44]\end{array}$ \\
\hline $\begin{array}{l}\text { 4.3.2 Sub-group F: Single taxane versus non- } \\
\text { taxane, non-anthracycline containing com- } \\
\text { bination regimen }\end{array}$ & 5 & 1244 & $\begin{array}{l}\text { Risk Ratio (M-H, Ran- } \\
\text { dom, } 95 \% \mathrm{Cl})\end{array}$ & $2.16[0.78,6.00]$ \\
\hline $\begin{array}{l}\text { 4.3.3 Sub-group G: Single non-taxane, non- } \\
\text { anthracycline agent versus other combina- } \\
\text { tion regimen }\end{array}$ & 2 & 416 & $\begin{array}{l}\text { Risk Ratio (M-H, Ran- } \\
\text { dom, } 95 \% \mathrm{CI})\end{array}$ & $0.72[0.31,1.66]$ \\
\hline
\end{tabular}




\section{Analysis 4.1. Comparison 4: Toxicity - Nausea and vomiting, Outcome 1: Nausea and vomiting - asssessable patients - all trials}

\begin{tabular}{lccccccc} 
& \multicolumn{2}{c}{ Combination } & \multicolumn{2}{c}{ Single agent } & \multicolumn{2}{c}{ Risk Ratio } & Risk Ratio \\
Study or Subgroup & Events & Total & Events & Total & Weight & M-H, Random, 95\% CI & M-H, Random, 95\% CI
\end{tabular}

\begin{tabular}{|c|c|c|c|c|c|}
\hline Albain KS 2004 & 2 & 262 & 2 & 259 & $1.6 \%$ \\
\hline Andersson M 1986 & 20 & 39 & 8 & 42 & $4.1 \%$ \\
\hline Berruti D 2002 & 24 & 90 & 17 & 91 & $4.5 \%$ \\
\hline Carmo-Pereira 1980 & 30 & 68 & 67 & 67 & $5.1 \%$ \\
\hline Ejlertsen B 2004 & 12 & 193 & 41 & 194 & $4.3 \%$ \\
\hline Falkson G 1990 & 6 & 52 & 2 & 51 & $2.2 \%$ \\
\hline GEICAM 2007 & 4 & 123 & 3 & 125 & $2.3 \%$ \\
\hline Gundersen S 1986 & 43 & 66 & 4 & 62 & $3.4 \%$ \\
\hline Heidemann E 2004 & 5 & 85 & 5 & 85 & $2.8 \%$ \\
\hline Ingle J 1985 & 12 & 77 & 11 & 74 & $3.9 \%$ \\
\hline Ingle J 1989 & 31 & 90 & 30 & 95 & $4.8 \%$ \\
\hline Joensuu H 1998 & 50 & 149 & 18 & 151 & $4.6 \%$ \\
\hline Norris B 2000 & 29 & 151 & 45 & 149 & $4.8 \%$ \\
\hline O'Shaughnessy J 2002 & 5 & 255 & 15 & 251 & $3.3 \%$ \\
\hline Sledge G(A) 2003 & 10 & 115 & 15 & 224 & $3.9 \%$ \\
\hline Sledge G(B) 2003 & 10 & 115 & 6 & 229 & $3.3 \%$ \\
\hline Steiner R 1983 & 47 & 54 & 42 & 53 & $5.2 \%$ \\
\hline Takayama T(A) 2000 & 0 & 54 & 1 & 57 & $0.7 \%$ \\
\hline Thomas E 2008 & 25 & 369 & 13 & 368 & $4.2 \%$ \\
\hline Vaughn CB 1988 & 2 & 56 & 10 & 59 & $2.3 \%$ \\
\hline Subtotal (95\% CI) & & 2463 & & 2686 & $71.4 \%$ \\
\hline Total events: & 367 & & 355 & & \\
\hline
\end{tabular}

Heterogeneity: $\mathrm{Tau}^{2}=0.44 ; \mathrm{Chi}^{2}=129.65, \mathrm{df}=19(\mathrm{P}<0.00001) ; \mathrm{I}^{2}=85 \%$

Test for overall effect: $\mathrm{Z}=0.82(\mathrm{P}=0.41)$

4.1.2 Question 2: Regimen A versus Regimen C (poly)

$\begin{array}{lrrrrr}\text { ANZBCTG 2001 } & 53 & 190 & 62 & 192 & 5.0 \% \\ \text { Bishop J 1999 } & 8 & 102 & 1 & 107 & 1.5 \% \\ \text { Bonneterre J 2002 } & 5 & 90 & 4 & 86 & 2.7 \% \\ \text { Fraser S 1993 } & 10 & 19 & 0 & 21 & 0.9 \% \\ \text { Heidemann E 2002 } & 37 & 125 & 9 & 131 & 4.1 \% \\ \text { Icli F 2005 } & 15 & 96 & 1 & 97 & 1.6 \% \\ \text { Nabholtz JM 1999 } & 9 & 187 & 14 & 200 & 3.8 \% \\ \text { O'Shaughnessy J 2001 } & 3 & 32 & 7 & 61 & 2.7 \% \\ \text { Sjostrom J 1999 } & 11 & 139 & 6 & 140 & 3.4 \% \\ \text { Stockler M 2006 } & 4 & 109 & 12 & 214 & 3.0 \% \\ \text { Subtotal (95\% CI) } & & \mathbf{1 0 8 9} & & \mathbf{1 2 4 9} & \mathbf{2 8 . 6 \%} \\ \text { Total events: } & 155 & & 116 & & \end{array}$

$0.86[0.64,1.17]$ $8.39[1.07,65.92]$

$1.19[0.33,4.30]$

$23.10[1.45,369.26]$

$4.31[2.17,8.56]$

$15.16[2.04,112.49]$

$0.69[0.30,1.55]$

$0.82[0.23,2.95]$

$1.85[0.70,4.85]$

$0.65[0.22,1.98]$

$1.79[0.93,3.43]$

Heterogeneity: $\mathrm{Tau}^{2}=0.70 ; \mathrm{Chi}^{2}=39.04, \mathrm{df}=9(\mathrm{P}<0.0001) ; \mathrm{I}^{2}=77 \%$

Test for overall effect: $\mathrm{Z}=1.75(\mathrm{P}=0.08)$

\section{Total (95\% CI)}

3552

Total events: 522 471

$3935 \quad 100.0 \%$

Heterogeneity: $\mathrm{Tau}^{2}=0.44 ; \mathrm{Chi}^{2}=172.40, \mathrm{df}=29(\mathrm{P}<0.00001) ; \mathrm{I}^{2}=83 \%$

Test for overall effect: $\mathrm{Z}=1.68(\mathrm{P}=0.09)$

Test for subgroup differences: $\mathrm{Chi}^{2}=1.31, \mathrm{df}=1(\mathrm{P}=0.25), \mathrm{I}^{2}=23.8 \%$

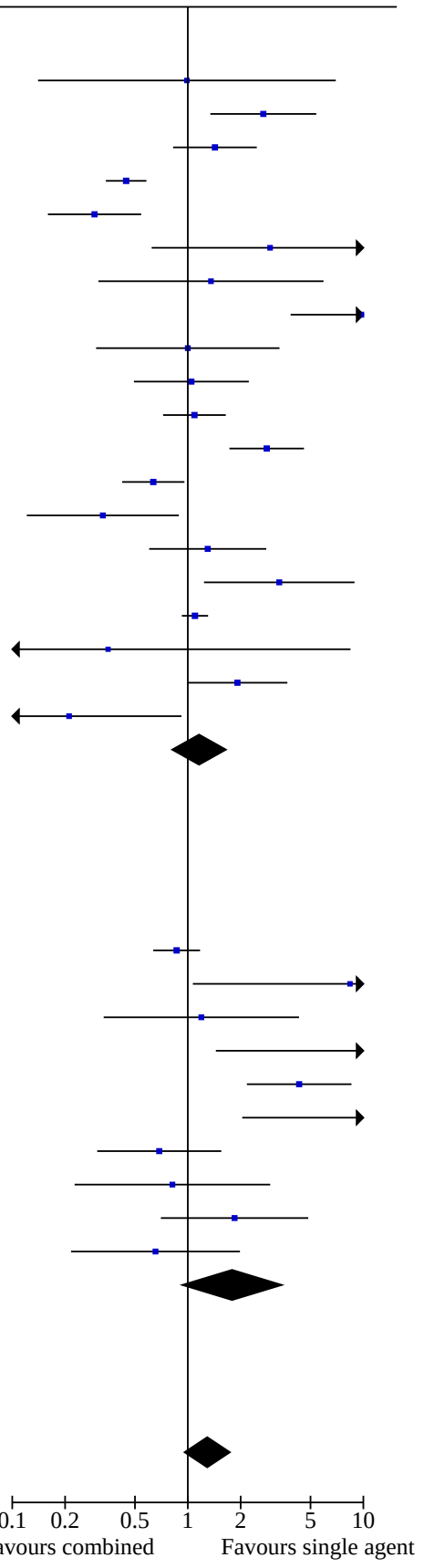


Analysis 4.2. Comparison 4: Toxicity - Nausea and vomiting, Outcome 2: Nausea and vomiting - Question 1 - Regimen A versus A + other - assessable patients

\begin{tabular}{|c|c|c|c|c|c|c|c|}
\hline \multirow{2}{*}{ Study or Subgroup } & \multicolumn{2}{|c|}{ Combination } & \multicolumn{2}{|c|}{ Single agent } & \multicolumn{2}{|r|}{ Risk Ratio } & \multirow{2}{*}{$\begin{array}{c}\text { Risk Ratio } \\
\text { M-H, Random, 95\% CI }\end{array}$} \\
\hline & Events & Total & Events & Tota & Weigl & M-H, Random, 95\% & \\
\hline
\end{tabular}

4.2.1 Sub-group A: Single antracycline agent versus anthracycline + other regimen

$\begin{array}{rr}20 & 39 \\ 24 & 90 \\ 12 & 193 \\ 43 & 66 \\ 5 & 85 \\ 12 & 77 \\ 31 & 90 \\ 50 & 149 \\ 29 & 151 \\ 15 & 251 \\ 10 & 230 \\ 2 & 56 \\ & \mathbf{1 4 7 7}\end{array}$

$\begin{array}{rrr}8 & 42 & 6.4 \% \\ 17 & 91 & 6.8 \% \\ 41 & 194 & 6.7 \% \\ 4 & 62 & 5.6 \% \\ 5 & 85 & 4.9 \% \\ 11 & 74 & 6.2 \% \\ 30 & 95 & 7.2 \% \\ 18 & 151 & 7.0 \% \\ 45 & 149 & 7.2 \% \\ 5 & 255 & 5.5 \% \\ 15 & 224 & 6.2 \% \\ 10 & 59 & 4.1 \% \\ & \mathbf{1 4 8 1} & \mathbf{7 3 . 7 \%}\end{array}$

Berruti D 2002

Ejlertsen B 2004

Gundersen S 1986

Heidemann E 2004

ngle J 1985

Ingle J 1989

Joensuu H 1998

Norris B 2000

O'Shaughnessy J 2002

Sledge G(A) 2003

Vaughn CB 1988

Subtotal (95\% CI)

253

209

Heterogeneity: $\mathrm{Tau}^{2}=0.64 ; \mathrm{Chi}^{2}=77.30, \mathrm{df}=11(\mathrm{P}<0.00001) ; \mathrm{I}^{2}=86 \%$

Test for overall effect: $\mathrm{Z}=0.82(\mathrm{P}=0.42)$

4.2.2 Sub group B: Single alkylating versus alkylating + other

$\begin{array}{llllll}\text { Falkson G } 1990 & 6 & 52 & 2 & 51 & 3.9 \% \\ \text { Subtotal (95\% CI) } & & \mathbf{5 2} & & \mathbf{5 1} & \mathbf{3 . 9 \%} \\ \text { Total events: } & 6 & & 2 & & \end{array}$

Heterogeneity: Not applicable

Test for overall effect: $\mathrm{Z}=1.36(\mathrm{P}=0.17)$

4.2.3 Sub group C: Single antimetabolite versus antimetabolite + other

$\begin{array}{lrrrrr}\text { Carmo-Pereira 1980 } & 30 & 68 & 67 & 67 & 7.4 \% \\ \text { Takayama T(A) 2000 } & 0 & 54 & 1 & 57 & 1.5 \% \\ \text { Subtotal (95\% CI) } & & \mathbf{1 2 2} & & \mathbf{1 2 4} & \mathbf{9 . 0 \%}\end{array}$

30

68

Heterogeneity: $\mathrm{Tau}^{2}=0.00 ; \mathrm{Chi}^{2}=0.02, \mathrm{df}=1(\mathrm{P}=0.88) ; \mathrm{I}^{2}=0 \%$

Test for overall effect: $\mathrm{Z}=6.00(\mathrm{P}<0.00001)$

4.2.4 Sub group D: Single taxane versus taxane + other

$\begin{array}{lrrrrr}\text { Albain KS 2004 } & 2 & 262 & 2 & 259 & 3.1 \% \\ \text { O'Shaughnessy J 2002 } & 5 & 255 & 5 & 251 & 4.8 \% \\ \text { Sledge G(B) 2003 } & 10 & 230 & 6 & 229 & 5.5 \% \\ \text { Subtotal (95\% CI) } & & \mathbf{7 4 7} & & \mathbf{7 3 9} & \mathbf{1 3 . 4 \%} \\ \text { Total events: } & 17 & & 13 & & \end{array}$

$0.99[0.14,6.97]$

$0.98[0.29,3.36]$

$1.66[0.61,4.49]$

$1.29[0.63,2.65]$

Heterogeneity: $\mathrm{Tau}^{2}=0.00 ; \mathrm{Chi}^{2}=0.50, \mathrm{df}=2(\mathrm{P}=0.78) ; \mathrm{I}^{2}=0 \%$

Test for overall effect: $\mathrm{Z}=0.70(\mathrm{P}=0.48)$

Total (95\% CI)

2398

Total events: 306 292

$2395100.0 \%$

列 ${ }^{2}=0.67 ; \mathrm{Chi}^{2}=120.84, \mathrm{df}=17(\mathrm{P}<0.00001) ; \mathrm{I}^{2}=86 \%$

Test for overall effect: $\mathrm{Z}=0.66(\mathrm{P}=0.51)$

Test for subgroup differences: $\mathrm{Chi}^{2}=21.03, \mathrm{df}=3(\mathrm{P}=0.0001), \mathrm{I}^{2}=85.7 \%$
$2.69[1.34,5.39]$

$1.43[0.82,2.47]$

$0.29[0.16,0.54]$

$10.10[3.85,26.48]$

$1.00[0.30,3.33]$

$1.05[0.49,2.23]$

$1.09[0.72,1.65]$

$2.82[1.73,4.59]$

$0.64[0.42,0.96]$

$3.05[1.12,8.26]$

$0.65[0.30,1.41]$

$0.21[0.05,0.92]$

$1.23[0.74,2.05]$

$0.45[0.34,0.58]$

$0.35[0.01,8.45]$

$0.44[0.34,0.58]$

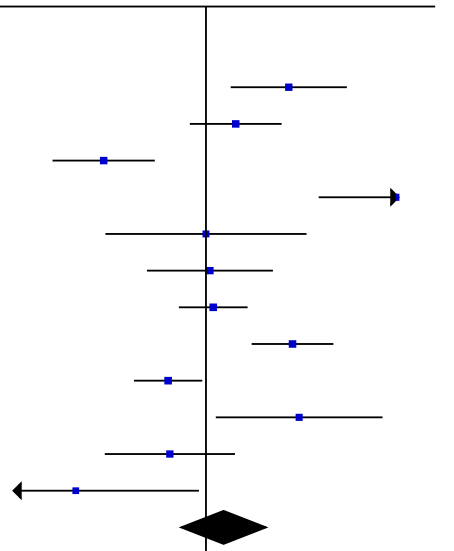


Analysis 4.3. Comparison 4: Toxicity - Nausea and vomiting, Outcome 3: Nausea and vomiting - Question 2 - Regimen A versus Regimen C - assessable patients

\begin{tabular}{lccccccc} 
& \multicolumn{2}{c}{ Combination } & \multicolumn{2}{c}{ Single agent } & \multicolumn{2}{c}{ Risk Ratio } & Risk Ratio \\
Study or Subgroup & Events & Total & Events & Total & Weight & M-H, Random, 95\% CI & M-H, Random, 95\% CI
\end{tabular}

$\begin{array}{lrrrrrr}\text { 4.3.1 Sub group E: Single anthracycline agent versus non-anthracycline combination regimen } \\ \text { ANZBCTG 2001 } & 53 & 190 & 62 & 192 & 20.1 \% & 0.86[0.64,1.17] \\ \text { Fraser S 1993 } & 10 & 19 & 0 & 21 & 3.9 \% & 23.10[1.45,369.26] \\ \text { Subtotal (95\% CI) } & & \mathbf{2 0 9} & & \mathbf{2 1 3} & \mathbf{2 4 . 0 \%} & \mathbf{3 . 4 4}[\mathbf{0 . 1 1}, \mathbf{1 0 4 . 4 4 ]} \\ \text { Total events: } & 63 & & 62 & & & \end{array}$

Heterogeneity: $\mathrm{Tau}^{2}=5.21 ; \mathrm{Chi}^{2}=6.15, \mathrm{df}=1(\mathrm{P}=0.01) ; \mathrm{I}^{2}=84 \%$

Test for overall effect: $\mathrm{Z}=0.71(\mathrm{P}=0.48)$

4.3.2 Sub-group F: Single taxane versus non-taxane, non-anthracycline containing combination regimen

Bonneterre J 2002

Icli F 2005

Nabholtz JM 1999

Sjostrom J 1999

Subtotal (95\% CI)

Total events:

Test for overall effect: $\mathrm{Z}=1.48(\mathrm{P}=0.14)$

4.3.3 Sub-group G: Single non-taxane, non-anthracycline agent versus other combination regimen O'Shaughnessy J 2001

Stockler M 2006

Subtotal (95\% CI)

Total events:

$\begin{array}{rr}8 & 102 \\ 5 & 90 \\ 15 & 96 \\ 9 & 187 \\ 11 & 139 \\ & \mathbf{6 1 4}\end{array}$

48

$\begin{array}{rrr}1 & 107 & 6.2 \% \\ 4 & 86 & 10.9 \% \\ 1 & 97 & 6.4 \% \\ 14 & 200 & 15.4 \% \\ 6 & 140 & 13.8 \% \\ & \mathbf{6 3 0} & \mathbf{5 2 . 6 \%}\end{array}$

8.39 [1.07, 65.92]

$1.19[0.33,4.30]$

$15.16[2.04,112.49]$

$0.69[0.30,1.55]$

$1.85[0.70,4.85]$

$2.16[0.78,6.00]$

26

Heterogeneity: $\mathrm{Tau}^{2}=0.00 ; \mathrm{Chi}^{2}=0.07, \mathrm{df}=1(\mathrm{P}=0.80) ; \mathrm{I}^{2}=0 \%$

Test for overall effect: $\mathrm{Z}=0.77(\mathrm{P}=0.44)$

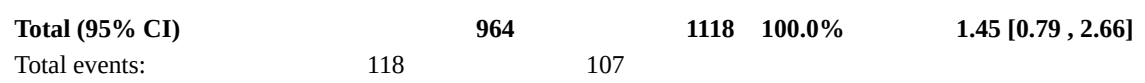

Heterogeneity: $\mathrm{Tau}^{2}=0.45 ; \mathrm{Chi}^{2}=22.66, \mathrm{df}=8(\mathrm{P}=0.004) ; \mathrm{I}^{2}=65 \%$

Test for overall effect: $\mathrm{Z}=1.20(\mathrm{P}=0.23)$

Test for subgroup differences: $\mathrm{Chi}^{2}=3.06, \mathrm{df}=2(\mathrm{P}=0.22), \mathrm{I}^{2}=34.7 \%$

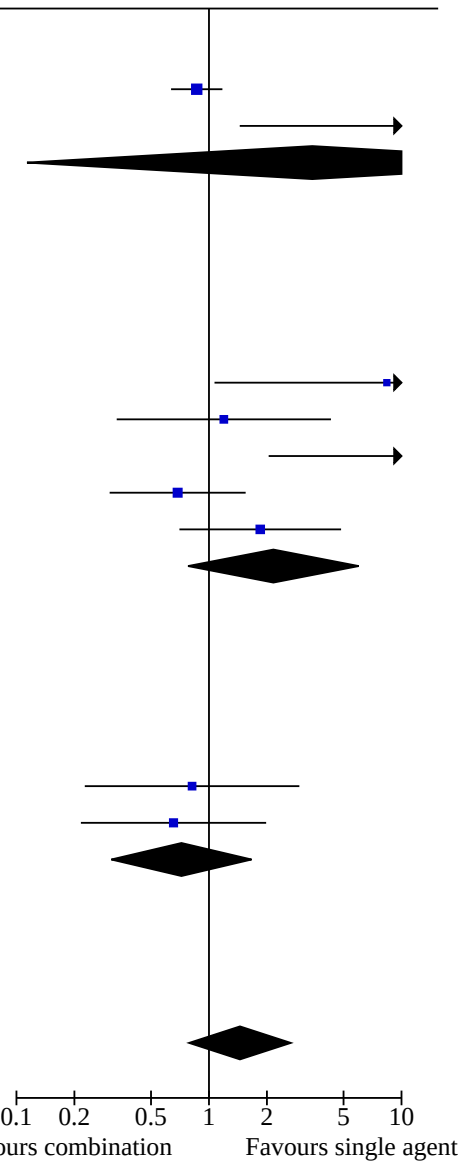

$0.82[0.23,2.95]$

$0.65[0.22,1.98]$

$0.72[0.31,1.66]$

$14 \quad 12.4 \%$

0.72 [0.31, 1.66$]$

\section{Comparison 5. Toxicity - White cell count}

\begin{tabular}{|c|c|c|c|c|}
\hline Outcome or subgroup title & No. of studies & $\begin{array}{l}\text { No. of partici- } \\
\text { pants }\end{array}$ & Statistical method & Effect size \\
\hline 5.1 WCC - assessable patients - all trials & 35 & 7810 & $\begin{array}{l}\text { Risk Ratio (M-H, Ran- } \\
\text { dom, } 95 \% \mathrm{Cl})\end{array}$ & $1.49[1.24,1.79]$ \\
\hline 5.1.1 Question1: Regimen A versus A +other & 21 & 5164 & $\begin{array}{l}\text { Risk Ratio (M-H, Ran- } \\
\text { dom, } 95 \% \mathrm{Cl})\end{array}$ & $1.69[1.30,2.20]$ \\
\hline $\begin{array}{l}\text { 5.1.2 Question 2: Regimen A versus Regimen } \\
\text { C }\end{array}$ & 14 & 2646 & $\begin{array}{l}\text { Risk Ratio (M-H, Ran- } \\
\text { dom, } 95 \% \mathrm{CI})\end{array}$ & $1.27[0.93,1.74]$ \\
\hline $\begin{array}{l}5.2 \text { WCC - Question } 1 \text { - Regimen A versus A + } \\
\text { other - assessable patients }\end{array}$ & 19 & 4463 & $\begin{array}{l}\text { Risk Ratio (M-H, Ran- } \\
\text { dom, } 95 \% \mathrm{Cl})\end{array}$ & $1.35[1.10,1.65]$ \\
\hline $\begin{array}{l}\text { 5.2.1 Sub group A: Single anthracycline } \\
\text { agent versus anthracycline + other regimen }\end{array}$ & 12 & 2974 & $\begin{array}{l}\text { Risk Ratio (M-H, Ran- } \\
\text { dom, } 95 \% \mathrm{Cl})\end{array}$ & $1.48[1.19,1.83]$ \\
\hline
\end{tabular}




\begin{tabular}{|c|c|c|c|c|}
\hline Outcome or subgroup title & No. of studies & $\begin{array}{l}\text { No. of partici- } \\
\text { pants }\end{array}$ & Statistical method & Effect size \\
\hline $\begin{array}{l}\text { 5.2.2 Sub group B: Single alkyating agent } \\
\text { versus alkylating agent + other }\end{array}$ & 3 & 263 & $\begin{array}{l}\text { Risk Ratio (M-H, Ran- } \\
\text { dom, } 95 \% \mathrm{Cl} \text { ) }\end{array}$ & $0.56[0.28,1.10]$ \\
\hline $\begin{array}{l}\text { 5.2.3 Sub group C: Single antimetabolite ver- } \\
\text { sus antimetabolite + other }\end{array}$ & 2 & 246 & $\begin{array}{l}\text { Risk Ratio (M-H, Ran- } \\
\text { dom, } 95 \% \mathrm{CI})\end{array}$ & $\begin{array}{l}28.06[3.85 \\
204.44]\end{array}$ \\
\hline $\begin{array}{l}\text { 5.2.4 Sub group D: Single taxane versus tax- } \\
\text { ane + other }\end{array}$ & 2 & 980 & $\begin{array}{l}\text { Risk Ratio (M-H, Ran- } \\
\text { dom, } 95 \% \mathrm{CI})\end{array}$ & $1.93[0.37,10.03]$ \\
\hline $\begin{array}{l}5.3 \text { WCC - Question } 2 \text { - Regimen A versus } \\
\text { Regimen C - assessable patients }\end{array}$ & 13 & 2367 & $\begin{array}{l}\text { Risk Ratio (M-H, Ran- } \\
\text { dom, } 95 \% \mathrm{CI})\end{array}$ & $1.54[1.08,2.18]$ \\
\hline $\begin{array}{l}\text { 5.3.1 Sub group E: Single anthracycline } \\
\text { agent versus non-anthracycline combina- } \\
\text { tion regimen }\end{array}$ & 3 & 665 & $\begin{array}{l}\text { Risk Ratio (M-H, Ran- } \\
\text { dom, } 95 \% \mathrm{CI})\end{array}$ & $1.08[0.85,1.37]$ \\
\hline $\begin{array}{l}\text { 5.3.2 Sub-group F: Single taxane versus non- } \\
\text { taxane, non-anthracycline containing com- } \\
\text { bination regimen }\end{array}$ & 4 & 965 & $\begin{array}{l}\text { Risk Ratio (M-H, Ran- } \\
\text { dom, } 95 \% \mathrm{CI})\end{array}$ & $1.34[0.85,2.11]$ \\
\hline $\begin{array}{l}\text { 5.3.3 Sub-group G: single non-taxane, non- } \\
\text { anthracycline agent versus other combina- } \\
\text { tion regimen }\end{array}$ & 6 & 737 & $\begin{array}{l}\text { Risk Ratio (M-H, Ran- } \\
\text { dom, } 95 \% \mathrm{CI})\end{array}$ & $1.70[0.43,6.63]$ \\
\hline
\end{tabular}


Analysis 5.1. Comparison 5: Toxicity - White cell count, Outcome 1: WCC - assessable patients - all trials

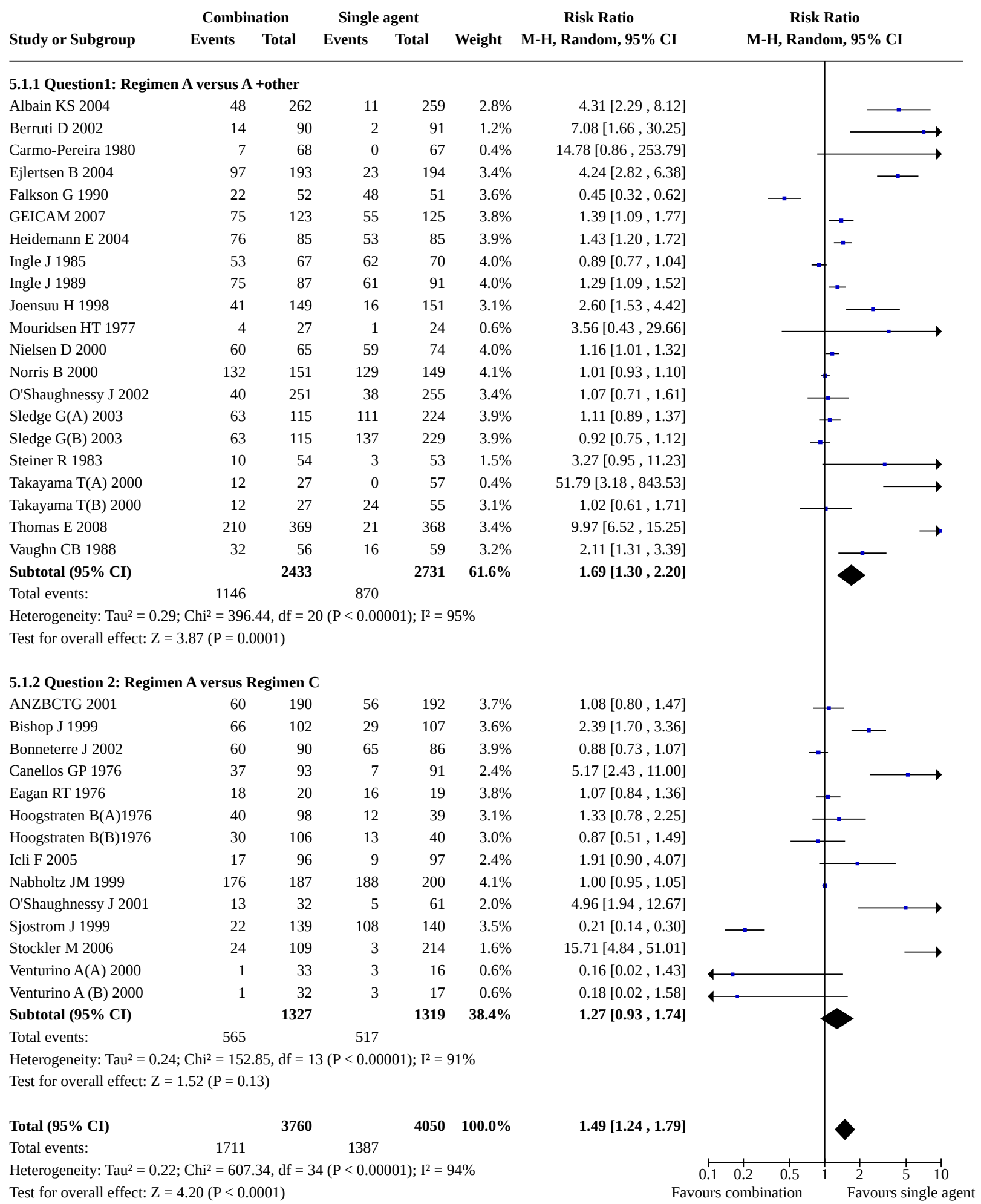


Analysis 5.2. Comparison 5: Toxicity - White cell count, Outcome 2: WCC - Question 1 - Regimen A versus A + other - assessable patients

\begin{tabular}{|c|c|c|c|c|c|}
\hline \multirow[b]{2}{*}{ tudy or Subgroup } & \multicolumn{2}{|c|}{ Combination } & \multicolumn{2}{|c|}{ Single agent } & Risk Ratio \\
\hline & Events & Total & Events & Tota & M-H, Random, 95\% CI \\
\hline
\end{tabular}

\begin{tabular}{lrrrrrr}
\hline \multicolumn{8}{l}{ 5.2.1 Sub group A: Single anthracycline agent versus anthracycline + } \\
Berruti D 2002 & 13 & 90 & 2 & 91 & $1.5 \%$ & $6.57[1.53,28.30]$ \\
Ejlertsen B 2004 & 97 & 193 & 23 & 194 & $6.0 \%$ & $4.24[2.82,6.38]$ \\
Heidemann E 2004 & 76 & 85 & 53 & 85 & $7.5 \%$ & $1.43[1.20,1.72]$ \\
Ingle J 1985 & 53 & 67 & 62 & 70 & $7.6 \%$ & $0.89[0.77,1.04]$ \\
Ingle J 1989 & 75 & 87 & 61 & 91 & $7.5 \%$ & $1.29[1.09,1.52]$ \\
Joensuu H 1998 & 41 & 149 & 16 & 151 & $5.1 \%$ & $2.60[1.53,4.42]$ \\
Nielsen D 2000 & 60 & 65 & 59 & 74 & $7.7 \%$ & $1.16[1.01,1.32]$ \\
Norris B 2000 & 132 & 151 & 129 & 149 & $7.8 \%$ & $1.01[0.93,1.10]$ \\
O'Shaughnessy J 2002 & 40 & 251 & 38 & 255 & $6.0 \%$ & $1.07[0.71,1.61]$ \\
Sledge G(A) 2003 & 126 & 230 & 111 & 224 & $7.5 \%$ & $1.11[0.93,1.32]$ \\
Steiner R 1983 & 10 & 54 & 3 & 53 & $2.0 \%$ & $3.27[0.95,11.23]$ \\
Vaughn CB 1988 & 32 & 56 & 16 & 59 & $5.5 \%$ & $2.11[1.31,3.39]$ \\
Subtotal (95\% CI) & & $\mathbf{1 4 7 8}$ & & $\mathbf{1 4 9 6}$ & $\mathbf{7 1 . 8 \%}$ & $\mathbf{1 . 4 8}[\mathbf{1 . 1 9}, \mathbf{1 . 8 3}]$ \\
Total events: & 755 & & 573 & & & \\
\end{tabular}

Heterogeneity: $\mathrm{Tau}^{2}=0.11 ; \mathrm{Chi}^{2}=126.08, \mathrm{df}=11(\mathrm{P}<0.00001) ; \mathrm{I}^{2}=91 \%$

Test for overall effect: $\mathrm{Z}=3.50(\mathrm{P}=0.0005)$

5.2.2 Sub group B: Single alkyating agent versus alkylating agent + other

$\begin{array}{lllllll}\text { Falkson G } 1990 & 22 & 52 & 48 & 51 & 6.6 \%\end{array}$

Mouridsen HT $1977 \quad 4 \quad 27 \quad 12 \quad 24 \quad 2.7 \%$

$\begin{array}{llllll}\text { Takayama T(B) } 2000 & 24 & 54 & 24 & 55 & 5.9 \%\end{array}$

$\begin{array}{llrr}\text { Subtotal }(95 \% \text { CI) } & 133 & 130 & 15.2 \%\end{array}$

Total events: $\quad 50 \quad 84$

Heterogeneity: $\mathrm{Tau}^{2}=0.27 ; \mathrm{Chi}^{2}=10.94, \mathrm{df}=2(\mathrm{P}=0.004) ; \mathrm{I}^{2}=82 \%$

Test for overall effect: $\mathrm{Z}=1.70(\mathrm{P}=0.09)$

5.2.3 Sub group C: Single antimetabolite versus antimetabolite + other

$\begin{array}{lrrrrrr}\text { Carmo-Pereira 1980 } & 7 & 68 & 0 & 67 & 0.5 \% & 14.78[0.86,253.79] \\ \text { Takayama T(A) 2000 } & 24 & 54 & 0 & 57 & 0.5 \% & 51.67[3.22,829.21] \\ \text { Subtotal (95\% CI) } & & \mathbf{1 2 2} & & \mathbf{1 2 4} & \mathbf{1 . 0 \%} & \mathbf{2 8 . 0 6}[3.85, \mathbf{2 0 4 . 4 4}] \\ \text { Total events: } & 31 & & 0 & & & \end{array}$

$\begin{array}{llc} & 31 & 0 \\ \text { Heterogeneity: } \mathrm{Tau}^{2}=0.00 ; \mathrm{Chi}^{2}=0.41, \mathrm{df}=1(\mathrm{P}=0.52) ; \mathrm{I}^{2}=0 \%\end{array}$

Test for overall effect: $\mathrm{Z}=3.29(\mathrm{P}=0.001)$

5.2.4 Sub group D: Single taxane versus taxane + other

\begin{tabular}{|c|c|c|c|c|c|c|}
\hline Albain KS 2004 & 48 & 262 & 11 & 259 & $4.5 \%$ & $4.31[2.29,8.12]$ \\
\hline Sledge G(B) 2003 & 126 & 230 & 137 & 229 & $7.6 \%$ & $0.92[0.78,1.07]$ \\
\hline Subtotal (95\% CI) & & 492 & & 488 & $12.0 \%$ & $1.93[0.37,10.03]$ \\
\hline
\end{tabular}

$0.45[0.32,0.62]$

$0.30[0.11,0.80]$

$1.02[0.67,1.56]$

$0.56[0.28,1.10]$

M-H, Random, 95\% CI

Heterogeneity: $\mathrm{Tau}^{2}=1.36 ; \mathrm{Chi}^{2}=25.53, \mathrm{df}=1(\mathrm{P}<0.00001) ; \mathrm{I}^{2}=96 \%$

Test for overall effect: $\mathrm{Z}=0.79(\mathrm{P}=0.43)$

Total (95\% CI)

2225

805

Heterogeneity: $\mathrm{Tau}^{2}=0.13 ; \mathrm{Chi}^{2}=194.46, \mathrm{df}=18(\mathrm{P}<0.00001) ; \mathrm{I}^{2}=91 \%$

Test for overall effect: $\mathrm{Z}=2.87(\mathrm{P}=0.004)$

Test for subgroup differences: $\mathrm{Chi}^{2}=16.24$, $\mathrm{df}=3(\mathrm{P}=0.001), \mathrm{I}^{2}=81.5 \%$ 


\section{Analysis 5.3. Comparison 5: Toxicity - White cell count, Outcome 3:} WCC - Question 2 - Regimen A versus Regimen C - assessable patients

\begin{tabular}{lccccccc} 
& \multicolumn{2}{c}{ Combination } & \multicolumn{2}{c}{ Single agent } & \multicolumn{2}{c}{ Risk Ratio } & Risk Ratio \\
Study or Subgroup & Events & Total & Events & Total & Weight & M-H, Random, 95\% CI & M-H, Random, 95\% CI
\end{tabular}

$\begin{array}{lcrrrrr}\text { 5.3.1 Sub group E: Single anthracycline agent versus non-anthracycline combination regimen } \\ \text { ANZBCTG 2001 } & 60 & 190 & 56 & 192 & 10.0 \% & 1.08 \text { [0.80, 1.47] } \\ \text { Hoogstraten B(A)1976 } & 40 & 98 & 12 & 39 & 8.7 \% & 1.33[0.78,2.25] \\ \text { Hoogstraten B(B)1976 } & 30 & 106 & 13 & 40 & 8.6 \% & 0.87[0.51,1.49] \\ \text { Subtotal (95\% CI) } & & \mathbf{3 9 4} & & \mathbf{2 7 1} & \mathbf{2 7 . 3 \%} & \mathbf{1 . 0 8 ~ [ 0 . 8 5 , \mathbf { 1 . 3 7 } ]}\end{array}$

Total events: $\quad 130 \quad 81$

Heterogeneity: $\mathrm{Tau}^{2}=0.00 ; \mathrm{Chi}^{2}=1.20, \mathrm{df}=2(\mathrm{P}=0.55) ; \mathrm{I}^{2}=0 \%$

Test for overall effect: $\mathrm{Z}=0.65(\mathrm{P}=0.52)$

5.3.2 Sub-group F: Single taxane versus non-taxane, non-anthracycline containing combination regimen $\begin{array}{lllllll}\text { Bishop J } 1999 & 66 & 102 & 29 & 107 & 9.8 \% & 2.39[1.70,3.36]\end{array}$

$\begin{array}{lllllll}\text { Bonneterre J } 2002 & 60 & 90 & 65 & 86 & 10.5 \% & 0.88[0.73,1.07]\end{array}$

Nabholtz JM 1999

$\begin{array}{ll}60 & 90 \\ 17 & 96\end{array}$

$96 \quad 9 \quad 97 \quad 7.2 \%$

$1.91[0.90,4.07]$

Subtotal (95\% CI)

$176 \quad 187$

188

$200 \quad 10.8 \%$

$1.00[0.95,1.05]$

Total events:

319

291

Heterogeneity: $\mathrm{Tau}^{2}=0.18 ; \mathrm{Chi}^{2}=52.35, \mathrm{df}=3(\mathrm{P}<0.00001) ; \mathrm{I}^{2}=94 \%$

Test for overall effect: $\mathrm{Z}=1.26(\mathrm{P}=0.21)$

5.3.3 Sub-group G: single non-taxane, non-anthracycline agent versus other combination regimen

Canellos GP 1976

Eagan RT 1976

O'Shaughnessy J 2001

Stockler M 2006

Venturino A(A) 2000

Venturino A (B) 2000

Subtotal (95\% CI)

Total events:

$\begin{array}{rr}37 & 93 \\ 18 & 20 \\ 13 & 32 \\ 26 & 109 \\ 1 & 33 \\ 1 & 32 \\ & 319\end{array}$

7
16
5
6
3
3

$\begin{array}{rr}91 & 7.2 \% \\ 19 & 10.3 \% \\ 61 & 6.1 \% \\ 214 & 6.6 \% \\ 16 & 2.1 \% \\ 17 & 2.1 \% \\ \mathbf{4 1 8} & \mathbf{3 4 . 4 \%}\end{array}$
5.17 [2.43, 11.00]
$1.07[0.84,1.36]$
4.96 [1.94 , 12.67]
8.51 [3.61, 20.05]
0.16 [0.02, 1.43]
$0.18[0.02,1.58]$
$1.70[0.43,6.63]$

40

Heterogeneity: $\mathrm{Tau}^{2}=2.47 ; \mathrm{Chi}^{2}=81.23, \mathrm{df}=5(\mathrm{P}<0.00001) ; \mathrm{I}^{2}=94 \%$

Test for overall effect: $\mathrm{Z}=0.76(\mathrm{P}=0.45)$

Total (95\% CI)

1188

$1179 \quad 100.0 \%$

Total events:

545

412

Heterogeneity: $\mathrm{Tau}^{2}=0.30 ; \mathrm{Chi}^{2}=171.48, \mathrm{df}=12(\mathrm{P}<0.00001) ; \mathrm{I}^{2}=93 \%$

Test for overall effect: $\mathrm{Z}=2.40(\mathrm{P}=0.02)$

Test for subgroup differences: $\mathrm{Chi}^{2}=1.00, \mathrm{df}=2(\mathrm{P}=0.61), \mathrm{I}^{2}=0 \%$

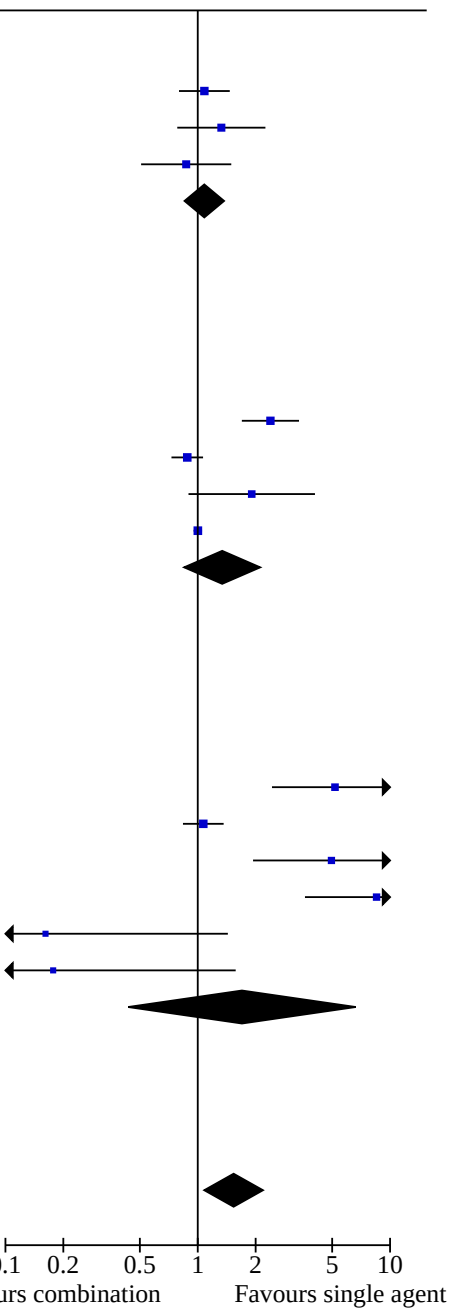

\section{Comparison 6. Toxicity - Alopecia}

\begin{tabular}{|c|c|c|c|c|}
\hline Outcome or subgroup title & No. of studies & $\begin{array}{l}\text { No. of partici- } \\
\text { pants }\end{array}$ & Statistical method & Effect size \\
\hline 6.1 Alopecia - assessable patients - all trials & 21 & 4818 & $\begin{array}{l}\text { Risk Ratio (M-H, Ran- } \\
\text { dom, } 95 \% \mathrm{Cl} \text { ) }\end{array}$ & $1.12[0.81,1.54]$ \\
\hline $\begin{array}{l}\text { 6.1.1 Question 1: Regimen A (single) versus A } \\
+ \text { other }\end{array}$ & 11 & 2778 & $\begin{array}{l}\text { Risk Ratio (M-H, Ran- } \\
\text { dom, } 95 \% \mathrm{Cl})\end{array}$ & $2.18[1.10,4.30]$ \\
\hline $\begin{array}{l}\text { 6.1.2 Question 2: Regimen A versus Regimen } \\
\text { C }\end{array}$ & 10 & 2040 & $\begin{array}{l}\text { Risk Ratio }(\mathrm{M}-\mathrm{H} \text {, Ran- } \\
\text { dom, } 95 \% \mathrm{Cl})\end{array}$ & $0.63[0.31,1.27]$ \\
\hline $\begin{array}{l}\text { 6.2 Alopecia - Question } 1 \text { - Regimen A versus } \\
\text { A + other - assessable patients }\end{array}$ & 9 & 2299 & $\begin{array}{l}\text { Risk Ratio (M-H, Ran- } \\
\text { dom, } 95 \% \mathrm{Cl})\end{array}$ & $1.86[0.96,3.64]$ \\
\hline
\end{tabular}

Single agent versus combination chemotherapy for metastatic breast cancer (Review) 


\begin{tabular}{|c|c|c|c|c|}
\hline Outcome or subgroup title & No. of studies & $\begin{array}{l}\text { No. of partici- } \\
\text { pants }\end{array}$ & Statistical method & Effect size \\
\hline $\begin{array}{l}\text { 6.2.1 Sub group A: Single anthracycline } \\
\text { agent versus anthracycline + other regimen }\end{array}$ & 7 & 1607 & $\begin{array}{l}\text { Risk Ratio (M-H, Ran- } \\
\text { dom, } 95 \% \mathrm{Cl})\end{array}$ & $1.53[0.82,2.85]$ \\
\hline $\begin{array}{l}\text { 6.2.2 Sub group B: Single alkyating agent } \\
\text { versus alkylating agent + other }\end{array}$ & 1 & 51 & $\begin{array}{l}\text { Risk Ratio (M-H, Ran- } \\
\text { dom, } 95 \% \mathrm{Cl} \text { ) }\end{array}$ & $2.33[1.28,4.25]$ \\
\hline $\begin{array}{l}\text { 6.2.3 Sub group C: Single antimetabolite ver- } \\
\text { sus antimetabolite }+ \text { other }\end{array}$ & 1 & 135 & $\begin{array}{l}\text { Risk Ratio (M-H, Ran- } \\
\text { dom, } 95 \% \mathrm{Cl})\end{array}$ & $\begin{array}{l}117.28[7.40 \\
1858.88]\end{array}$ \\
\hline $\begin{array}{l}\text { 6.2.4 Sub group D: Single taxane versus tax- } \\
\text { ane + other }\end{array}$ & 1 & 506 & $\begin{array}{l}\text { Risk Ratio (M-H, Ran- } \\
\text { dom, } 95 \% \mathrm{Cl})\end{array}$ & $1.18[0.61,2.29]$ \\
\hline $\begin{array}{l}\text { 6.3 Alopecia - Question } 2 \text { - Regimen A versus } \\
\text { Regimen C -assessable patients }\end{array}$ & 9 & 1784 & $\begin{array}{l}\text { Risk Ratio (M-H, Ran- } \\
\text { dom, } 95 \% \mathrm{Cl})\end{array}$ & $0.40[0.21,0.78]$ \\
\hline $\begin{array}{l}\text { 6.3.1 Sub group E: Single anthracycline } \\
\text { agent versus non-anthracycline combina- } \\
\text { tion regimen }\end{array}$ & 3 & 665 & $\begin{array}{l}\text { Risk Ratio (M-H, Ran- } \\
\text { dom, } 95 \% \mathrm{Cl})\end{array}$ & $0.27[0.05,1.40]$ \\
\hline $\begin{array}{l}\text { 6.3.2 Sub-group F: Single taxane versus non- } \\
\text { taxane, non-anthracycline containing com- } \\
\text { bination regimen }\end{array}$ & 3 & 664 & $\begin{array}{l}\text { Risk Ratio (M-H, Ran- } \\
\text { dom, } 95 \% \mathrm{Cl})\end{array}$ & $0.26[0.19,0.35]$ \\
\hline $\begin{array}{l}\text { 6.3.3 Sub-group G: single non-taxane, non- } \\
\text { anthracycline agent versus other combina- } \\
\text { tion regimen }\end{array}$ & 3 & 455 & $\begin{array}{l}\text { Risk Ratio (M-H, Ran- } \\
\text { dom, } 95 \% \mathrm{Cl})\end{array}$ & $2.05[0.38,11.18]$ \\
\hline
\end{tabular}


Analysis 6.1. Comparison 6: Toxicity - Alopecia, Outcome 1: Alopecia - assessable patients - all trials

\begin{tabular}{|c|c|c|c|c|c|c|c|c|c|}
\hline \multirow[b]{2}{*}{ Study or Subgroup } & \multicolumn{2}{|c|}{ Combination } & \multicolumn{2}{|c|}{ Single agent } & \multirow[b]{2}{*}{ Weight } & \multirow{2}{*}{$\begin{array}{c}\text { Risk Ratio } \\
\text { M-H, Random, 95\% CI }\end{array}$} & \multirow{2}{*}{\multicolumn{2}{|c|}{$\begin{array}{c}\text { Risk Ratio } \\
\text { M-H, Random, } 95 \% \text { CI }\end{array}$}} & \\
\hline & Events & Total & Events & Total & & & & & \\
\hline \multicolumn{10}{|c|}{ 6.1.1 Question 1: Regimen A (single) versus A + other } \\
\hline Carmo-Pereira 1980 & 59 & 68 & 0 & 67 & $1.1 \%$ & $117.28[7.40,1858.88]$ & & & $\rightarrow$ \\
\hline GEICAM 2007 & 21 & 123 & 21 & 125 & $5.4 \%$ & $1.02[0.59,1.76]$ & & & \\
\hline Gundersen S 1986 & 52 & 66 & 5 & 62 & $4.4 \%$ & $9.77[4.18,22.85]$ & & & $\rightarrow$ \\
\hline Ingle J 1985 & 26 & 77 & 41 & 74 & $5.9 \%$ & $0.61[0.42,0.89]$ & $\because-$ & & \\
\hline Joensuu H 1998 & 105 & 149 & 19 & 151 & $5.7 \%$ & $5.60[3.63,8.64]$ & & & - \\
\hline Mouridsen HT 1977 & 21 & 27 & 8 & 24 & $5.2 \%$ & $2.33[1.28,4.25]$ & & & \\
\hline Norris B 2000 & 33 & 151 & 36 & 149 & $5.8 \%$ & $0.90[0.60,1.37]$ & & & \\
\hline O'Shaughnessy J 2002 & 18 & 255 & 15 & 251 & $5.0 \%$ & $1.18[0.61,2.29]$ & & & \\
\hline Steiner R 1983 & 47 & 54 & 44 & 53 & $6.3 \%$ & $1.05[0.89,1.23]$ & & & \\
\hline Thomas E 2008 & 27 & 369 & 3 & 368 & $3.4 \%$ & $8.98[2.75,29.33]$ & & & $\longrightarrow$ \\
\hline Vaughn CB 1988 & 56 & 56 & 57 & 59 & $6.4 \%$ & $1.03[0.98,1.10]$ & & & \\
\hline Subtotal $(95 \%$ CI) & & 1395 & & 1383 & $54.7 \%$ & $2.18[1.10,4.30]$ & & & \\
\hline Total events: & 465 & & 249 & & & & & & \\
\hline \multicolumn{10}{|c|}{ Heterogeneity: $\mathrm{Tau}^{2}=1.16 ; \mathrm{Chi}^{2}=541.67, \mathrm{df}=10(\mathrm{P}<0.00001) ; \mathrm{I}^{2}=98 \%$} \\
\hline \multicolumn{10}{|c|}{ Test for overall effect: $\mathrm{Z}=2.24(\mathrm{P}=0.03)$} \\
\hline \multicolumn{10}{|c|}{ 6.1.2 Question 2: Regimen A versus Regimen C } \\
\hline ANZBCTG 2001 & 131 & 190 & 83 & 192 & $6.3 \%$ & $1.59[1.32,1.93]$ & & $=$ & \\
\hline Bishop J 1999 & 24 & 102 & 81 & 107 & $5.9 \%$ & $0.31[0.22,0.45]$ & & & \\
\hline Bonneterre J 2002 & 7 & 90 & 38 & 86 & $4.7 \%$ & $0.18[0.08,0.37]$ & & & \\
\hline Eagan RT 1976 & 19 & 20 & 17 & 19 & $6.3 \%$ & $1.06[0.88,1.28]$ & & & \\
\hline Heidemann E 2002 & 77 & 125 & 6 & 131 & $4.6 \%$ & $13.45[6.08,29.75]$ & & & $\longrightarrow$ \\
\hline Hoogstraten B(A)1976 & 5 & 98 & 23 & 39 & $4.3 \%$ & $0.09[0.04,0.21]$ & $\longleftarrow$ & & \\
\hline Hoogstraten B(B)1976 & 13 & 106 & 24 & 40 & $5.3 \%$ & $0.20[0.12,0.36]$ & $\longrightarrow$ & & \\
\hline O'Shaughnessy J 2001 & 1 & 32 & 0 & 61 & $0.9 \%$ & $5.64[0.24,134.54]$ & & & $\longrightarrow$ \\
\hline Sjostrom J 1999 & 17 & 139 & 74 & 140 & $5.6 \%$ & $0.23[0.14,0.37]$ & $\longrightarrow$ & & \\
\hline Stockler M 2006 & 2 & 109 & 1 & 214 & $1.4 \%$ & $3.93[0.36,42.83]$ & & & $\longrightarrow$ \\
\hline Subtotal $(95 \%$ CI) & & 1011 & & 1029 & $45.3 \%$ & $0.63[0.31,1.27]$ & & & \\
\hline Total events: & 296 & & 347 & & & & & & \\
\hline \multicolumn{10}{|c|}{ Heterogeneity: $\mathrm{Tau}^{2}=1.03 ; \mathrm{Chi}^{2}=226.53, \mathrm{df}=9(\mathrm{P}<0.00001) ; \mathrm{I}^{2}=96 \%$} \\
\hline \multicolumn{10}{|c|}{ Test for overall effect: $\mathrm{Z}=1.29(\mathrm{P}=0.20)$} \\
\hline Total $(95 \%$ CI) & & 2406 & & 2412 & $100.0 \%$ & $1.12[0.81,1.54]$ & & & \\
\hline Total events: & 761 & & 596 & & & & & & \\
\hline \multicolumn{7}{|c|}{ Heterogeneity: $\mathrm{Tau}^{2}=0.41 ; \mathrm{Chi}^{2}=394.44, \mathrm{df}=20(\mathrm{P}<0.00001) ; \mathrm{I}^{2}=95 \%$} & $\begin{array}{lll}\vdash \\
0.1 & 0.2 & 0.5\end{array}$ & 2 & 10 \\
\hline Test for overall effect: Z & $0.70(P=0$. & & & & & & ours combination & Favours si & ngle agent \\
\hline
\end{tabular}




\section{Analysis 6.2. Comparison 6: Toxicity - Alopecia, Outcome 2: Alopecia - Question 1 - Regimen A versus A + other - assessable patients}

\begin{tabular}{lccccccc} 
& \multicolumn{2}{c}{ Combination } & \multicolumn{2}{c}{ Single agent } & \multicolumn{2}{c}{ Risk Ratio } & Risk Ratio \\
Study or Subgroup & Events & Total & Events & Total & Weight & M-H, Random, 95\% CI & M-H, Random, 95\% CI
\end{tabular}

\begin{tabular}{|c|c|c|c|c|c|c|}
\hline Gundersen S 1986 & 52 & 66 & 5 & 62 & $9.6 \%$ & $9.77[4.18,22.85]$ \\
\hline Ingle J 1985 & 26 & 77 & 41 & 74 & $11.0 \%$ & $0.61[0.42,0.89]$ \\
\hline Joensuu H 1998 & 105 & 149 & 19 & 151 & $10.9 \%$ & $5.60[3.63,8.64]$ \\
\hline Norris B 2000 & 33 & 151 & 36 & 149 & $10.9 \%$ & $0.90[0.60,1.37]$ \\
\hline O'Shaughnessy J 2002 & 15 & 251 & 18 & 255 & $10.3 \%$ & $0.85[0.44,1.64]$ \\
\hline Steiner R 1983 & 47 & 54 & 44 & 53 & $11.3 \%$ & $1.05[0.89,1.23]$ \\
\hline Vaughn CB 1988 & 56 & 56 & 57 & 59 & $11.4 \%$ & $1.03[0.98,1.10]$ \\
\hline Subtotal (95\% CI) & & 804 & & 803 & $75.4 \%$ & $1.53[0.82,2.85]$ \\
\hline Total events: & 334 & & 220 & & & \\
\hline
\end{tabular}

Heterogeneity: $\mathrm{Tau}^{2}=0.64 ; \mathrm{Chi}^{2}=271.53, \mathrm{df}=6(\mathrm{P}<0.00001) ; \mathrm{I}^{2}=98 \%$

Test for overall effect: $\mathrm{Z}=1.35(\mathrm{P}=0.18)$

6.2.2 Sub group B: Single alkyating agent versus alkylating agent + other

$\begin{array}{lllllll}\text { Mouridsen HT 1977 } & 21 & 27 & 8 & 24 & 10.4 \% & 2.33[1.28,4.25] \\ \text { Subtotal (95\% CI) } & & 27 & & \mathbf{2 4} & \mathbf{1 0 . 4 \%} & \mathbf{2 . 3 3}[\mathbf{1 . 2 8}, \mathbf{4 . 2 5}] \\ \text { Total events: } & 21 & & 8 & & & \end{array}$

Heterogeneity: Not applicable

Test for overall effect: $\mathrm{Z}=2.76(\mathrm{P}=0.006)$

6.2.3 Sub group C: Single antimetabolite versus antimetabolite + other

$\begin{array}{lcccccc}\text { Carmo-Pereira 1980 } & 59 & 68 & 0 & 67 & 3.9 \% & 117.28[7.40,1858.88] \\ \text { Subtotal (95\% CI) } & & \mathbf{6 8} & & \mathbf{6 7} & \mathbf{3 . 9 \%} & \mathbf{1 1 7 . 2 8}[\mathbf{7 . 4 0 , \mathbf { 1 8 5 8 . 8 8 } ]} \\ \text { Total events: } & 59 & & 0 & & & \end{array}$

Heterogeneity: Not applicable

Test for overall effect: $\mathrm{Z}=3.38(\mathrm{P}=0.0007)$

6.2.4 Sub group D: Single taxane versus taxane + other

$\begin{array}{lllllll}\text { O'Shaughnessy J 2002 } & 18 & 255 & 15 & 251 & 10.3 \% & 1.18[0.61,2.29] \\ \text { Subtotal (95\% CI) } & & \mathbf{2 5 5} & & \mathbf{2 5 1} & \mathbf{1 0 . 3 \%} & \mathbf{1 . 1 8}[\mathbf{0 . 6 1 , 2 . 2 9 ]}\end{array}$

Heterogeneity: Not applicable

Test for overall effect: $\mathrm{Z}=0.49(\mathrm{P}=0.62)$

Total (95\% CI)

1154

Total events: 432

Heterogeneity: $\mathrm{Tau}^{2}=1.02 ; \mathrm{Chi}^{2}=462.65, \mathrm{df}=9(\mathrm{P}<0.00001) ; \mathrm{I}^{2}=98 \%$

Test for overall effect: $\mathrm{Z}=1.83(\mathrm{P}=0.07)$

Test for subgroup differences: $\mathrm{Chi}^{2}=11.30, \mathrm{df}=3(\mathrm{P}=0.01), \mathrm{I}^{2}=73.4 \%$ 


\section{Analysis 6.3. Comparison 6: Toxicity - Alopecia, Outcome 3: Alopecia - Question 2 - Regimen A versus Regimen C -assessable patients}

\begin{tabular}{lccccccc} 
& \multicolumn{2}{c}{ Combination } & \multicolumn{2}{c}{ Single agent } & \multicolumn{2}{c}{ Risk Ratio } & Risk Ratio \\
Study or Subgroup & Events & Total & Events & Total & Weight & M-H, Random, 95\% CI & M-H, Random, 95\% CI
\end{tabular}

6.3.1 Sub group E: Single anthracycline agent versus non-anthracycline combination regimen ANZBCTG 2001

Hoogstraten B(A)1976

Hoogstraten B(B)1976

$\begin{array}{rrrrr}131 & 190 & 131 & 192 & 14.2 \% \\ 5 & 98 & 23 & 39 & 11.3 \% \\ 13 & 106 & 24 & 40 & 12.9 \%\end{array}$

$1.01[0.88,1.16]$

Subtotal (95\% CI)

394

$271 \quad 38.4 \%$

$0.09[0.04,0.21]$

$0.20[0.12,0.36]$

Total events: $149 \quad 178$

Heterogeneity: $\mathrm{Tau}^{2}=2.01 ; \mathrm{Chi}^{2}=65.05$, df = $2(\mathrm{P}<0.00001) ; \mathrm{I}^{2}=97 \%$

Test for overall effect: $\mathrm{Z}=1.56(\mathrm{P}=0.12)$

6.3.2 Sub-group F: Single taxane versus non-taxane, non-anthracycline containing combination regimen

$\begin{array}{lrrrrrr}\text { Bishop J 1999 } & 24 & 102 & 81 & 107 & 13.7 \% & 0.31[0.22,0.45] \\ \text { Bonneterre J 2002 } & 7 & 90 & 38 & 86 & 12.1 \% & 0.18[0.08,0.37] \\ \text { Sjostrom J 1999 } & 17 & 139 & 74 & 140 & 13.3 \% & 0.23[0.14,0.37] \\ \text { Subtotal (95\% CI) } & & \mathbf{3 3 1} & & \mathbf{3 3 3} & \mathbf{3 9 . 1 \%} & \mathbf{0 . 2 6}[\mathbf{0 . 1 9}, \mathbf{0 . 3 5}] \\ \text { Total events: } & 48 & & 193 & & & \end{array}$

Heterogeneity: $\mathrm{Tau}^{2}=0.01 ; \mathrm{Chi}^{2}=2.25, \mathrm{df}=2(\mathrm{P}=0.32) ; \mathrm{I}^{2}=11 \%$

Test for overall effect: $Z=9.03(P<0.00001)$

6.3.3 Sub-group G: single non-taxane, non-anthracycline agent versus other combination regimen

$\begin{array}{lrrrrrr}\text { Eagan RT 1976 } & 19 & 20 & 17 & 19 & 14.1 \% & 1.06[0.88,1.28] \\ \text { O'Shaughnessy J 2001 } & 1 & 32 & 0 & 61 & 3.4 \% & 5.64[0.24,134.54] \\ \text { Stockler M 2006 } & 2 & 109 & 1 & 214 & 5.0 \% & 3.93[0.36, \mathbf{4 2 . 8 3}] \\ \text { Subtotal (95\% CI) } & & \mathbf{1 6 1} & & \mathbf{2 9 4} & \mathbf{2 2 . 5 \%} & \mathbf{2 . 0 5}[\mathbf{0 . 3 8 , \mathbf { 1 1 . 1 8 }}] \\ \text { Total events: } & 22 & & 18 & & & \end{array}$

$\begin{array}{lll}\text { Total events: } & 22 & 18 \\ \text { Heterogeneity: } \mathrm{Tau}^{2}=1.36 ; \mathrm{Chi}^{2}= & 4.84, \mathrm{df}=2(\mathrm{P}=0.09) ; \mathrm{I}^{2}=59 \%\end{array}$

Test for overall effect: $\mathrm{Z}=0.83(\mathrm{P}=0.41)$

$\begin{array}{lllll}\text { Total }(95 \% \text { CI }) & 886 & 898 & 100.0 \% & 0.40[0.21,0.78\end{array}$

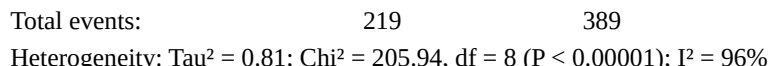

Test for overall effect: $\mathrm{Z}=2.68(\mathrm{P}=0.007)$

Test for subgroup differences: $\mathrm{Chi}^{2}=5.55, \mathrm{df}=2(\mathrm{P}=0.06), \mathrm{I}^{2}=64.0 \%$
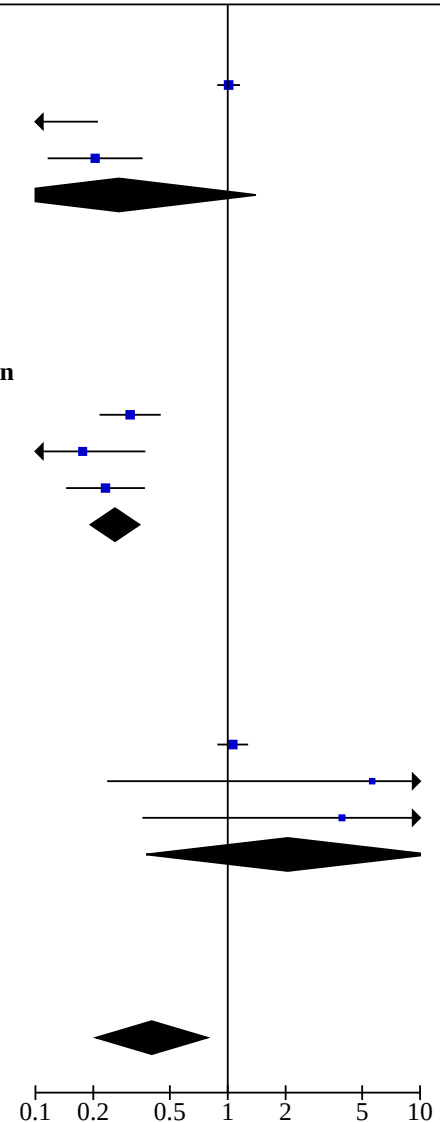

Favours combination $\quad$ Favours single agent

\section{Comparison 7. Treatment related death}

\begin{tabular}{lllll}
\hline Outcome or subgroup title & No. of studies & $\begin{array}{l}\text { No. of partici- } \\
\text { pants }\end{array}$ & Statistical method & Effect size \\
\hline $\begin{array}{l}\text { 7.1 Treatment related death - assessable } \\
\text { patients - all trials }\end{array}$ & 24 & 5856 & $\begin{array}{l}\text { Risk Ratio (M-H, Random, } \\
95 \% \mathrm{Cl})\end{array}$ \\
\hline $\begin{array}{l}\text { 7.1.1 Question 1: Regimen A (single) versus } \\
\text { Regimen A + other }\end{array}$ & 17 & 4611 & $\begin{array}{l}\text { Risk Ratio (M-H, Random, } \\
95 \% \mathrm{Cl})\end{array}$ \\
\hline $\begin{array}{l}\text { 7.1.2 Question 2: Regimen A (single) versus } 1.66] \\
\text { Regimen C }\end{array}$ & 7 & $1.14[0.69,1.88]$ \\
\hline
\end{tabular}




\section{Analysis 7.1. Comparison 7: Treatment related death, Outcome 1: Treatment related death - assessable patients - all trials}

\begin{tabular}{lrrrrr}
\multicolumn{7}{c}{$\begin{array}{c}\text { Combination } \\
\text { Study or Subgroup }\end{array}$} & $\begin{array}{l}\text { Single agent } \\
\text { Events }\end{array}$ & Total & Events & Total & Weight \\
\hline 7.1.1 Question 1: Regimen A (single) & versus Regimen A + other \\
Albain KS 2004 & 1 & 262 & 1 & 259 & $2.3 \%$ \\
Andersson M 1986 & 0 & 45 & 4 & 44 & $2.1 \%$ \\
Berruti D 2002 & 3 & 92 & 3 & 93 & $7.0 \%$ \\
Ejlertsen B 2004 & 8 & 193 & 3 & 194 & $10.0 \%$ \\
GEICAM 2007 & 1 & 123 & 1 & 125 & $2.3 \%$ \\
Ingle J 1985 & 0 & 77 & 3 & 74 & $2.0 \%$ \\
Ingle J 1989 & 1 & 90 & 2 & 95 & $3.0 \%$ \\
Nielsen D 2000 & 4 & 74 & 2 & 81 & $6.2 \%$ \\
Nielson D 1990 & 0 & 67 & 4 & 76 & $2.1 \%$ \\
Norris B 2000 & 1 & 151 & 2 & 149 & $3.0 \%$ \\
O'Shaughnessy J 2002 & 4 & 251 & 1 & 255 & $3.6 \%$ \\
Rubens RD 1975 & 0 & 50 & 1 & 49 & $1.7 \%$ \\
Sledge G(A) 2003 & 2 & 115 & 6 & 224 & $6.9 \%$ \\
Sledge G(B) 2003 & 2 & 115 & 4 & 229 & $6.1 \%$ \\
Steiner R 1983 & 1 & 54 & 1 & 53 & $2.3 \%$ \\
Thomas E 2008 & 12 & 369 & 3 & 368 & $10.9 \%$ \\
Vaughn CB 1988 & 0 & 56 & 1 & 59 & $1.7 \%$ \\
Subtotal (95\% CI) & & $\mathbf{2 1 8 4}$ & & $\mathbf{2 4 2 7}$ & $\mathbf{7 3 . 2 \%}$ \\
Total events: & 40 & & 42 & &
\end{tabular}

Risk Ratio

M-H, Random, 95\% CI
Risk Ratio

M-H, Random, 95\% CI

Heterogeneity: $\mathrm{Tau}^{2}=0.05 ; \mathrm{Chi}^{2}=16.72, \mathrm{df}=16(\mathrm{P}=0.40) ; \mathrm{I}^{2}=4 \%$

Test for overall effect: $\mathrm{Z}=0.52(\mathrm{P}=0.61)$

7.1.2 Question 2: Regimen A (single) versus Regimen C

$\begin{array}{lrrrrr}\text { Bonneterre J 2002 } & 5 & 90 & 1 & 88 & 3.8 \% \\ \text { Eagan RT 1976 } & 1 & 20 & 0 & 19 & 1.8 \% \\ \text { Erkisi M 1997 } & 1 & 30 & 0 & 30 & 1.7 \% \\ \text { Icli F 2005 } & 2 & 100 & 4 & 101 & 6.2 \% \\ \text { Nabholtz JM 1999 } & 3 & 189 & 4 & 203 & 7.9 \% \\ \text { O'Shaughnessy J 2001 } & 0 & 32 & 3 & 61 & 2.0 \% \\ \text { Sjostrom J 1999 } & 1 & 139 & 3 & 143 & 3.4 \% \\ \text { Subtotal (95\% CI) } & & \mathbf{6 0 0} & & \mathbf{6 4 5} & \mathbf{2 6 . 8 \%}\end{array}$
Total events: 13 15

Heterogeneity: $\mathrm{Tau}^{2}=0.00 ; \mathrm{Chi}^{2}=5.36, \mathrm{df}=6(\mathrm{P}=0.50) ; \mathrm{I}^{2}=0 \%$ Test for overall effect: $\mathrm{Z}=0.22(\mathrm{P}=0.83)$

\begin{tabular}{|c|}
\hline Total (95\% CI) \\
\hline \\
\hline
\end{tabular}

Heterogeneity: $\mathrm{Tau}^{2}=0.00 ; \mathrm{Chi}^{2}=22.27, \mathrm{df}=23(\mathrm{P}=0.50) ; \mathrm{I}^{2}=0 \%$ Test for overall effect: $\mathrm{Z}=0.43(\mathrm{P}=0.67)$

Test for subgroup differences: $\mathrm{Chi}^{2}=0.21, \mathrm{df}=1(\mathrm{P}=0.65), \mathrm{I}^{2}=0 \%$
$4.89[0.58,41.01]$ $2.86[0.12,66.11]$ $3.00[0.13,70.83]$ $0.51[0.09,2.70]$ $0.81[0.18,3.55]$ $0.27[0.01,5.04]$ $0.34[0.04,3.26]$

$0.91[0.41,2.04]$

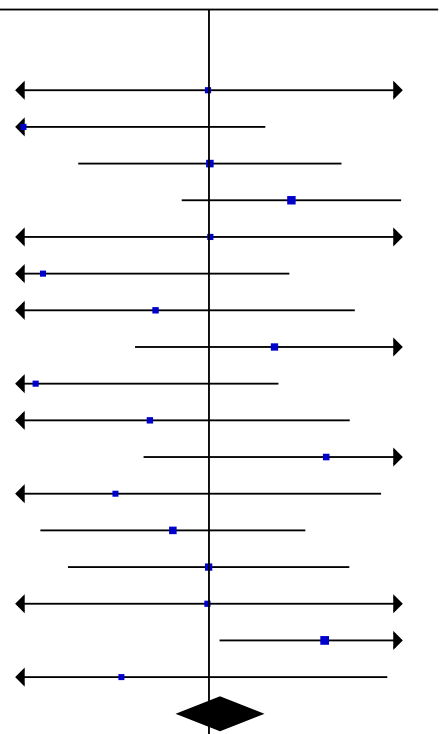

$0.99[0.06,15.72]$

$2.68[0.72,9.95]$

$1.02[0.06,16.07]$

$0.14[0.01,2.61]$

$0.13[0.01,2.29]$

$0.49[0.05,5.38]$

$4.06[0.46,36.11]$

$0.33[0.01,7.83]$

$0.65[0.13,3.17]$

$1.00[0.19,5.36]$

$0.98[0.06,15.29]$

3.99 [1.14, 14.02]

$0.35[0.01,8.44]$

1.14 [0.69, 1.88]
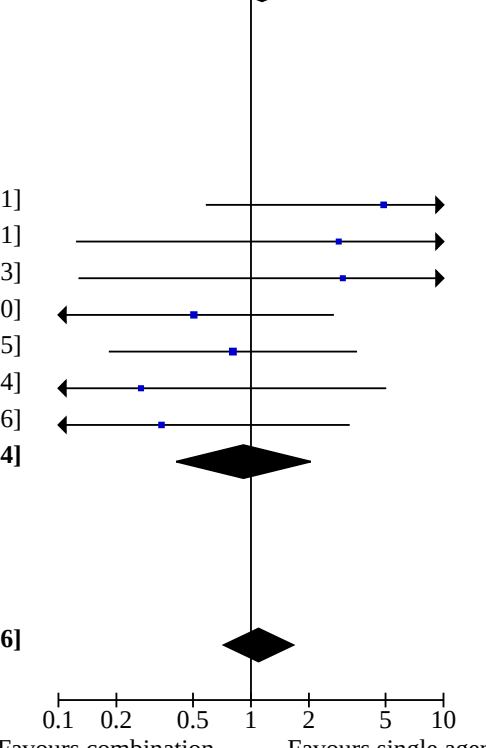

ADDITIONAL TABLES

Table 1. Quality of life

\begin{tabular}{|c|c|c|}
\hline Trial ID & Instruments used & Summary of findings \\
\hline Albain 2004 & $\begin{array}{l}\text { Patients completed a } \\
\text { Brief Pain Inventory (BPI) } \\
\text { and Rotterdam Symptom } \\
\text { Checklist (RSCL) prior to } \\
\text { each cycle }\end{array}$ & $\begin{array}{l}291 \text { patients completed BPI and } 350 \text { completed RSCL. The mean RSCL global } \\
\text { QOL score for patients receiving the combined regimen was significantly and } \\
\text { consistently better than that reported by the patients in the single drug arm; } \\
\text { this was also clinically significant. Mean changes and trends in pain intensity } \\
\text { and interference were similar across treatment arms }\end{array}$ \\
\hline
\end{tabular}


Table 1. Quality of life (Continued)

$\begin{array}{ll}\text { ANZBCTG } 2001 & \text { Patients completed 14 } \\ & \text { linear analogue assess- } \\ & \text { ment scales; the clin- } \\ & \text { ician used the Spitzer } \\ & \text { QL-index, at least each 3 } \\ & \text { months. }\end{array}$

Bishop 1999 (ANZ TITG) Patients completed linear analog scales (LASA) sand physician completed Spitzer QOL index
Patient rated quality of life was significantly better for CMFP than Mitoxantrone over the first 3 months, in terms of pain, mood and nausea and vomiting, though worse in terms of hair loss and similar overall.

\section{Fraser 1993 \\ Patients completed 3 quality of life instru- ments: 4 weekly Notting- ham Health Profile (NHP - emotional state, energy, pain, physical mobility, sleep and social factors ) and Linear Analogue Self- Assessment (LASA) at the start of treatment and four weekly thereafter and the Qualitator dai- ly diary card throughout treatment which mea- sured the domains of physical symptoms, so- cial factors, emotional factors and physical per- formance.}

QOL measures (physical well-being, mood, nausea and vomiting, appetite, overall quality of life and physician-rated quality of life) were slightly better in the taxane arm. The exception was pain which was slightly better in the nontaxane arm. Differences were not statistically significant.
Of the 40 patients randomised, compliance for the 29 who started the Qualitator, the 37 who started the NHP and 36 who started theLASA respectively were $88 \%, 89 \%$ and $92 \%$. Quality of life measures only recorded a significant difference in energy and pain, influenced primarily by the non responders in each treatment group but with no difference in overall global scores. Scores for responders ( $58 \%$ for CMF, $29 \%$ for epirubicin, $P>0.05$ ), irrespective of treatment were better to start with (LASA $P=0.001)$; at 12 weeks, scores had improved (Qualitator $\mathrm{P}<0.05$; NHP $\mathrm{P}<0.05$ ). Scores in non responders showed no change.

\section{Heideman 2002}

$87 \%(201 / 238)$ of randomised patients, treated until progression returned QOL questionnaires. $100 \%$ complete data was available to calculate the MBS for $46 \%$ patients (110/238). 38\% patients (91/238) had single missing values but where evaluable. A significant gain from treatment was reported for the mitoxantrone arm $(P=<0.001)$ explained as a result of significantly less hair loss and nausea/vomiting. baseline, and day 1 of each cycle. A modified Brunners score (MBS) was applied to assess gain from treatment.

\begin{tabular}{ll}
\hline Joensuu 1998 & Patients completed the \\
& Rotterdam Symptom \\
& Checklist (RSCL) which \\
& includes 30 QOL items \\
& grouped in two subscales \\
& that correspond to psy- \\
& chological and physical \\
& distress and eight items \\
& that describe physical ac- \\
& tivities
\end{tabular}

Data on QOL were available for $94 \%$ of randomised patients (285/303). No difference between the two arms was found in the psychological dimension of QOL analysis. Patients treated with epirubicin (single agent) showed less physical distress at 6 months after commencing treatment $(P=0.002)$ with scores tending to be lower also for that group at other times chosen for analysis. Similarly patients treated with epirubicin reported less nausea $(P$ $<0.01)$. They also reported less stomach pain, diarrhoea, hair loss and itching although this was not statistically significant. Patients in the combination group were more likely to report the therapy to be difficult at 6 and 9 months from randomisation than those in the single group $(P=0.04$ and 0.02 respectively)

$72 \%$ of questionnaires returned for docetaxel and $68 \%$ for MV for baseline and cycle 2, but deteriorated to $59 \%$ for docetaxel and $61 \%$ for MV by cycle 8. Attrition more evident in MV and did not occur at random. Significantly higher proportion of patients in MV discontinued treatment due to deterioration in condition: authors conclude that patients in the poorest health did 
Table 1. Quality of life (Continued)

not complete QOL questionnaires, hence QOL may be overestimated in both groups. Groups similar at baseline for global health, physical functioning and symptoms except for role functioning and diarrhoea (imbalance in favour of docetaxel). Results: No signficant difference in global health status. Significant difference in favour of docetaxel for nausea/vomiting and loss of appetite, and in favour of MV for role and social functioning.

$\begin{array}{ll}\text { Norris B 2000 } & \text { EORTC QLQ-C30 Global } \\ & \text { Health Score at baseline } \\ & \text { on or before day } 1 \text { of the } \\ & \text { first cycle of chemothera- } \\ & \text { py and at cycle } 3 \text { and cy- } \\ & \text { cle } 6 .\end{array}$

In total 230 patients ( 3 cycles of treatment) filled out 2-4 questionnaires and 191 patients ( 6 cycles of treatment) filled out 2-5 questionnaires. There was no significant difference between the arms or the profiles of the mean global QOL scores or any of the 8 additional domains (cognitive, emotional, physical, role, social, fatigue, nausea/vomiting and pain) over the first 6 cycles. QOL scores showed a significant improvement over time in the global, emotional, social, pain, and nausea/vomiting domains for patients receiving $6 \mathrm{cy}$ cles.

$\begin{array}{ll}\text { Sledge } 2003 \text { (ECOG } & \text { Patients completed } \\ \text { E1193) } & \text { FACT-B }\end{array}$

$93 \%(687 / 738)$ of randomised patients, and $94 \%(640 / 683)$ of eligible patients completed the baseline survey. $70 \%(451 / 683)$ of eligible patients completed the follow up survey at week 16 . The authors concluded that there was no statistically significant difference in overall quality of life score, or in any of the subscales, between any of the treatment groups.

$\begin{array}{ll}\text { Sjostrom } 1999 & \text { Patients completed } \\ \text { EORTC QLQ-C30 }\end{array}$

Overall compliance with return of questionnaires for entire study was $82 \%$. Physical deterioration greater in MF hence possible bias in its favour. No statistically significant difference at baseline or by cycle 4 in any functional or symptom scale. No significant difference in median values of mean changes in QOL scores from baseline to cycle 6.

O'Shaughnessy $2002 \quad$ Patients completed the EORTC QLQ-C30 Global Health Score. A comparison of treatment arms was made at day 127.
No significant difference was found between the treatment arms. There was a trend towards less deterioration of Global Health Score in the combination arm over time. The impact of chemotherapy induced side effects, as measured by the systemic therapy side effects symptom scale, was similar in the two treatment arms.

WHAT'S NEW

\begin{tabular}{lll}
\hline Date & Event & Description \\
\hline 6 February 2018 & Review declared as stable & $\begin{array}{l}\text { This clinical question has been replaced. Instead, it was im- } \\
\text { portant to know whether giving a combination of drugs at the } \\
\text { same time was more effective than giving the same drugs one } \\
\text { at a time (sequential treatment). This question has been cov- } \\
\text { ered in a new Cochrane review. See http://onlinelibrary.wi- } \\
\text { ley.com/doi/10.1002/14651858.CD008792.pub2/abstract }\end{array}$ \\
\end{tabular}

\section{H I S T ORY}

Protocol first published: Issue 4, 2001

Review first published: Issue 2, 2005

\begin{tabular}{lll}
\hline Date & Event & Description \\
\hline 19 February 2009 & New search has been performed & Review update Issue 2, 2009 \\
\hline \hline
\end{tabular}

Single agent versus combination chemotherapy for metastatic breast cancer (Review) 


\begin{tabular}{lll}
\hline Date & Event & Description \\
\hline 18 February 2009 & $\begin{array}{l}\text { New citation required but conclusions } \\
\text { have not changed }\end{array}$ & Accumulation of changes \\
\hline 7 May 2008 & New search has been performed & Update of review \\
\hline 7 May 2008 & Amended & Converted to new review format. \\
\hline 24 January 2008 & Amended & republished with updated contact details \\
\hline 23 February 2005 & $\begin{array}{l}\text { New citation required and conclusions } \\
\text { have changed }\end{array}$ & First publication of the review \\
\hline 28 August 2001 & Amended & First publication protocol \\
\hline
\end{tabular}

\section{CONTRIBUTIONS OFAUTHORS}

For the 2008 update of this review CT undertook the search and assessed trials for eligibility with SP and SC. CT, SP and SC extracted data from all new trials and those with additional information. These three authors updated data tables. SP and SC revised the text of the review and updated the results and discussion which was reviewed by NW. SP and SC retrospectively assessed trials for quality using the Cochrane Risk of Bias tool. SP revised and re-formatted all figures.

For the first publication of this review in 2005 SC undertook the review including assessment of trial eligibility, data extraction, analyses and writing of the review. SP conducted the eligibility assessment, extracted and entered data and contributed to the interpretation. JS, NW and DG provided clinical input and commented on the drafts of the first review.

DG designed the review protocol.

\section{DECLARATIONS OF INTEREST}

Nil conflict of interest

\section{SOURCES OF SUPPORT}

\section{Internal sources}

- NHMRC Clinical Trials Centre, Australia

\section{External sources}

- U.S. Army Medical Research Acquisition Activity, USA

\section{DIFFERENCES BETWEEN PROTOCOLANDREVIEW}

Post-hoc subgroup analyses were conducted for type of regimen. In addition studies incorporating non-standard chemotherapy (high dose chemotherapy) were excluded as these are the subject of a separate review.

\section{NOTES}

This review was updated in August 2008. A new search was conducted March 2008 and the review has undergone significant and accumulated change. A summary of changes is included below:

New trials added:

Albain 2004; Ejlertsen 2004; GEICAM 2007; Heidemann 2004; Norris 2000; O'Shaughnessy 2001; Stockler 2006; Thomas 2007

Additional data added for previously included trials:

Heidemann 2002 - Overall survival and TTP curve data re-done

Updated survival information for O'Shaunnessy 2002 (Norris paper) minimum 27mths follow up

Updated data for Icli 2002 - Now Icli 2005

Trials removed from the 2005 systematic review:

Keller 2004- Was included in initial review based on data obtained from ASCO 2001 conference proceeding (Abstact number 115). This trial was subsequently removed from the updated review following retrieval of the full published paper (2004) which further clarified the 
regimens studied. Of the 151 participants in the control arm 129 were receiving single agent vinorelbine and 22 received mitomycin $C$ plus vinblastine. Data was not provided separately for combination and single agent regimens within the control group.

Liu 1986 - Was included in the initial review but excluded at update. This exclusion was based on a post hoc consideration to not include high dose chemotherapy regimens. Clinical discussion confirmed that this review should reflect standard/conventional chemotherapy regimens

Trials previously in ongoing - now excluded from the review (See Characteristics of excluded studies table):

Anonymous 2002; Doroshow 2000; Jackish 1999; Perez 2001

New ongoing trial:

Butler 2004

All data was checked for this update and all sections of the text revised. The background and discussion was re-written. Risk of bias tables were done retrospectively for all 43 trials ( 48 comparisons)

\section{INDEX TERMS}

\section{Medical Subject Headings (MeSH)}

Antineoplastic Agents [*administration \& dosage]; Antineoplastic Combined Chemotherapy Protocols [ ${ }^{*}$ administration \& dosage]; Breast Neoplasms [ ${ }^{\star}$ drug therapy] [mortality]; Disease Progression; Quality of Life; Randomized Controlled Trials as Topic; Treatment Outcome

\section{MeSH check words}

Female; Humans 